\title{
Electricity Reform Abroad and U.S. Investment
}

\author{
October 1997
}

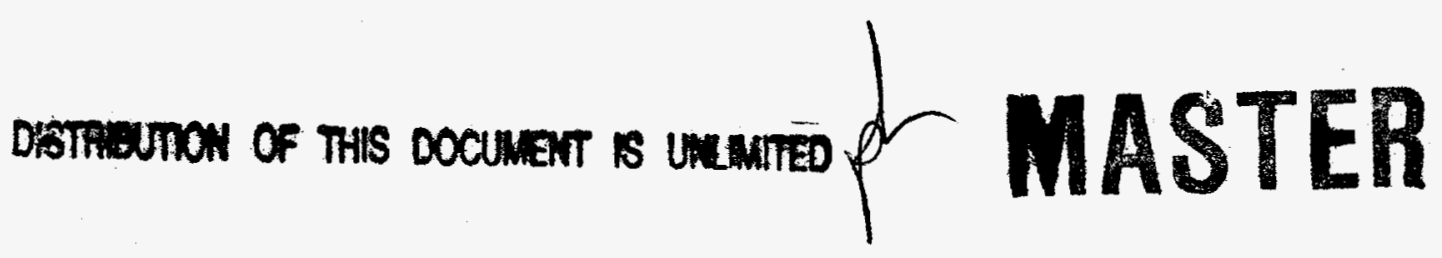

\author{
Energy Information Administration \\ Office of Energy Markets and End Use \\ U.S. Department of Energy \\ Washington, DC 20585
}

This report was prepared by the Energy Information Administration, the independent statistical and analytical agency within the Department of Energy. The information contained herein should not be construed as advocating or reflecting any policy position of the Department of Energy or any other organization. 


\section{Contacts}

This report was prepared in the Office of Energy Markets and End Use of the Energy Information Administration, U.S. Department of Energy, under the general direction of W. Calvin Kilgore. General questions concerning the content of the report may be referred to Mark E. Rodekohr, Director of the Energy Markets and Contingency Information Division (202/586-1130), and Mary E. Northup, Chief of the Financial Analysis Branch
(202/586-1445). Kathy L. Washington performed the formatting and desktop publishing efforts for this report. Specific technical information concerning this report may be obtained from Kevin Lillis (202/586-1395) or Jon Rasmussen (202/586-1449). The following authors contributed to this report: Neal Davis (Chapter 4), Susanne Johnson (Chapter 3), Kevin Lillis (Executive Summary, Chapters 1 and 2), and Jon Rasmussen (Chapter 1). 


\section{DISCLAMMER}

Portions of this doement may be illegible in electronic image produets. Images are produced from the best available original docement. 


\section{Contents}

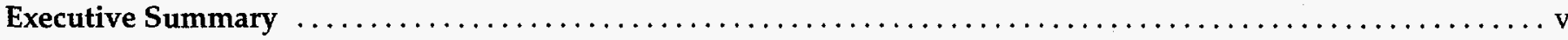

1. Electricity Reform Abroad: Experiments in Argentina, Australia, and the United Kingdom ............ 3

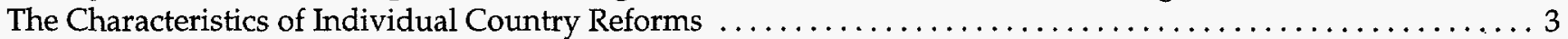

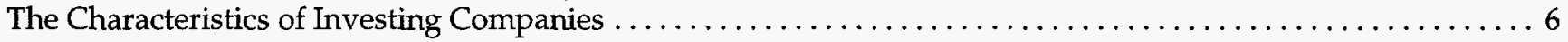

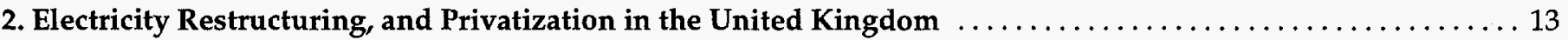

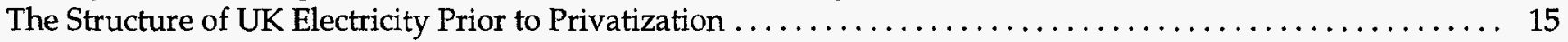

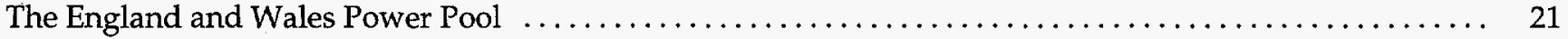

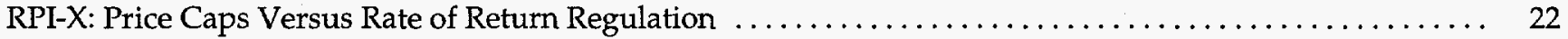

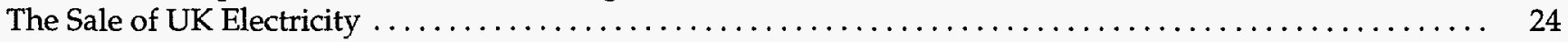

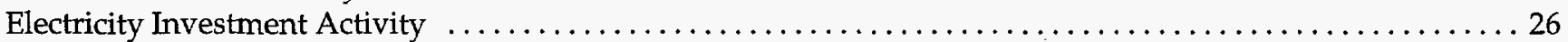

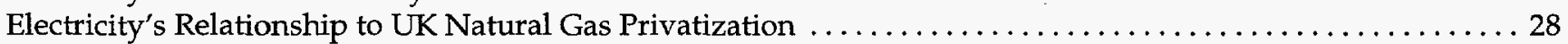

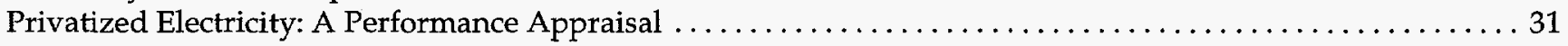

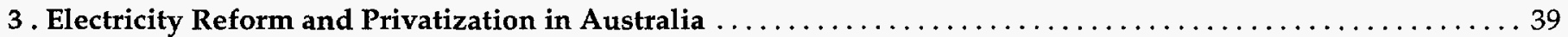

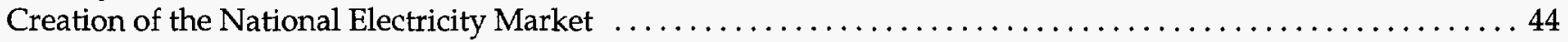

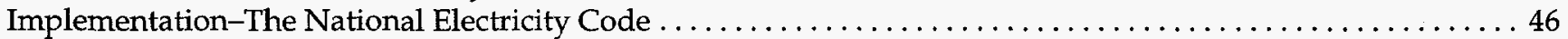

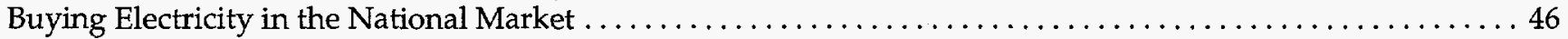

Electricity Reform at the State and Territory Levels $\ldots \ldots \ldots \ldots \ldots \ldots \ldots \ldots \ldots \ldots \ldots \ldots \ldots \ldots \ldots \ldots$

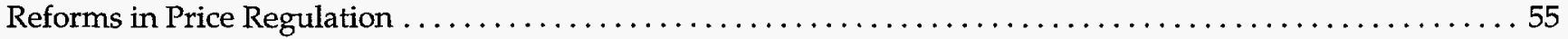

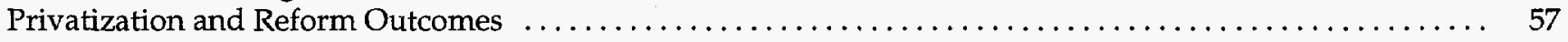

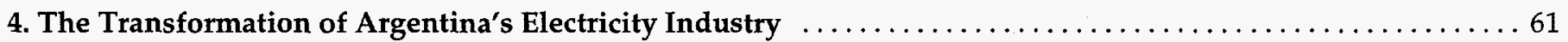

An Historical Perspective for Argentine Privatization Efforts $\ldots \ldots \ldots \ldots \ldots \ldots \ldots \ldots \ldots \ldots \ldots \ldots, 63$

Changes in Legislation and International Agreements $\ldots \ldots \ldots \ldots \ldots \ldots \ldots \ldots \ldots \ldots \ldots \ldots \ldots \ldots, 6, \ldots \ldots$

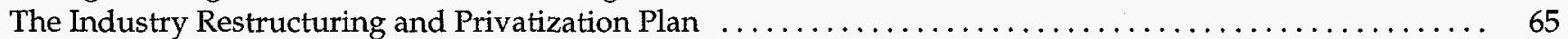

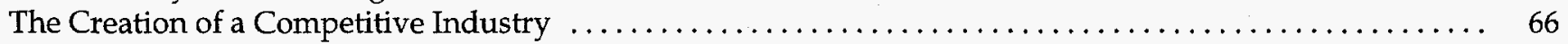

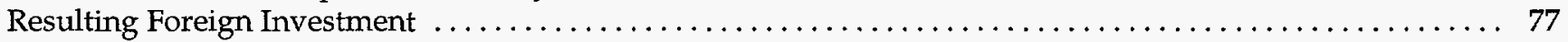

Appendices

A. U.S. Electric Utility Companies Not Investing in Argentina, Australia and the United Kingdom . . . . . . . 85

B. Electricity Reform Milestones in Argentina, Australia, and the United Kingdom . . . . . . . . . . . . 89

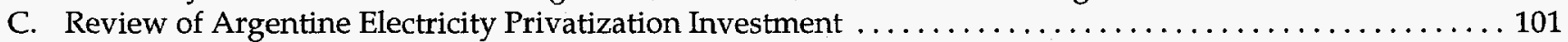

\section{Tables}

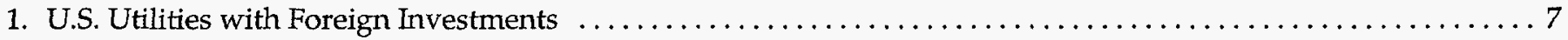

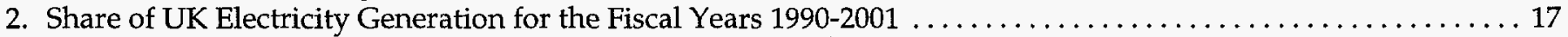

3. Regional Electricity Distribution Companies in the United Kingdom Ranked by Electricity Distributed,

Fiscal Year $1994 / 1995$......................................................... 19

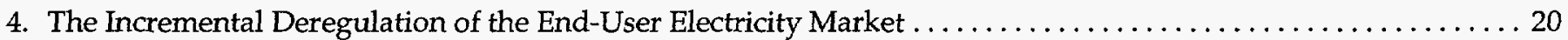

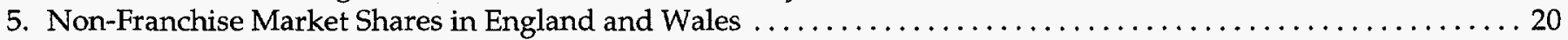

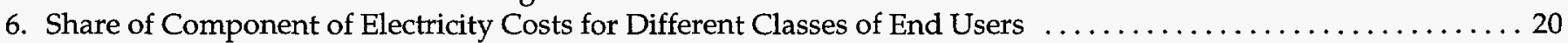

7. The UK's Office of Energy Regulation RPI-X Price Controls, and Review Periods $\ldots \ldots \ldots \ldots \ldots \ldots \ldots \ldots 23$ 


\section{Tables (continued)}

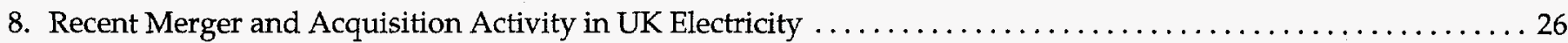

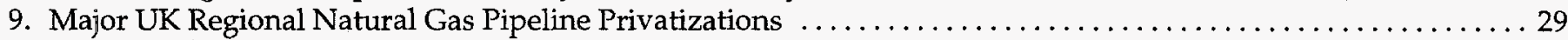

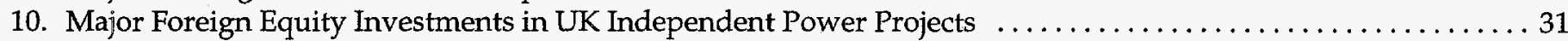

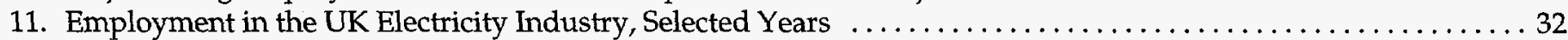

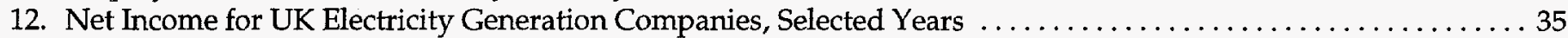

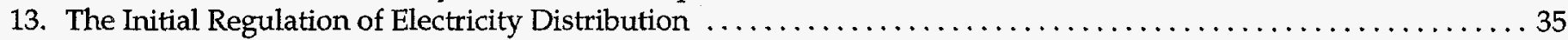

14. Australian Electricity Profile: Consumption By Class of Customer and Population in $1995 \ldots \ldots \ldots \ldots \ldots \ldots . \ldots 4$

15. Australian Electricity Consumption, Generation, Imports, and Capacity by State and Territory, 1995 . . . . . 4 42

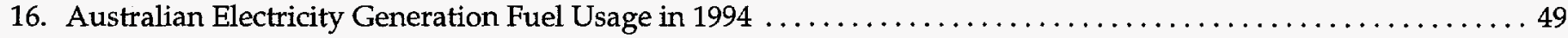

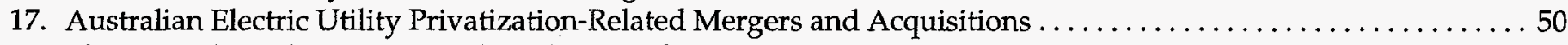

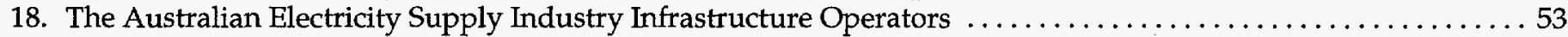

19. Net Production of Argentine Electricity by Independent and Public Producers, $1985-1995 \ldots \ldots \ldots \ldots \ldots \ldots$

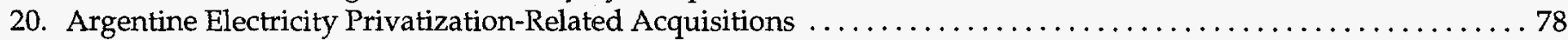

A1. U.S. Electric Utility Companies Net Investing in Argentina, Australia, and the United Kingdom . . . . . . . . 887

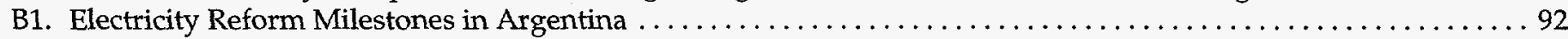

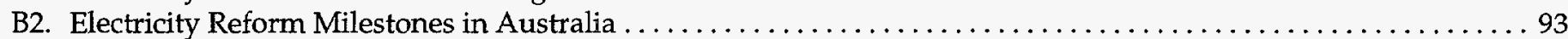

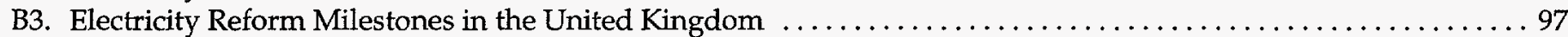

C1. Foreign Companies with Investments in Argentina's Electricity Industry, as of 1997 . . . . . . . . . . . . . . 104

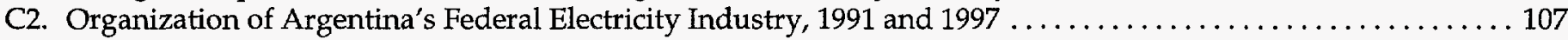

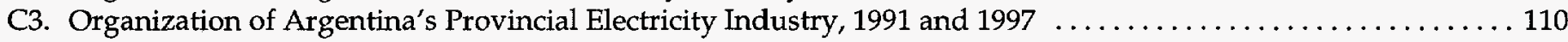

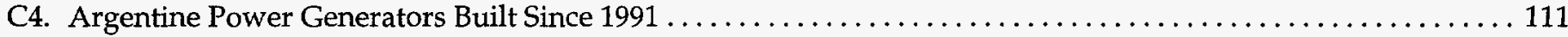

\section{Illustrations}

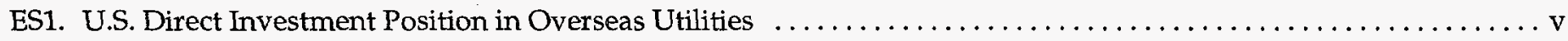

ES2. U.S. Direct Investment Position in Australian and UK Other Industries $\ldots \ldots \ldots \ldots \ldots \ldots \ldots \ldots \ldots \ldots \ldots$

ES3. An Example of the Transformation of a National Electricity Industry to a Restructured Industry Along

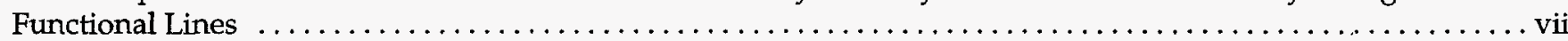

1. Market-to-Book Ratio for Foreign Investing Electric Utilities and Other Electric Utilities, 1987-1996 . . . . . . . 7

2. Regional Distribution of Sales for Foreign Investing Electric Utilities and Other Electric Utilities, $1995 \ldots \ldots \ldots 7$

3. Dividend Payout Ratio of Foreign Investing Electric Utilities and Other Electric Utilities, 1987-1996 . . . . . . . 8

4. Return on Equity of Foreign Investing Electric Utilities and Other Electric Utilities, $1987-1996 \ldots \ldots \ldots \ldots \ldots .8$

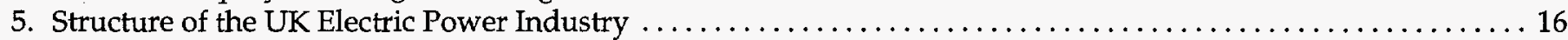

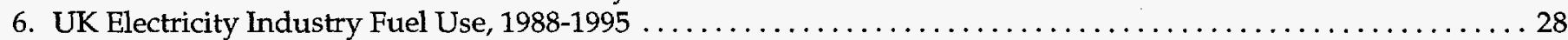

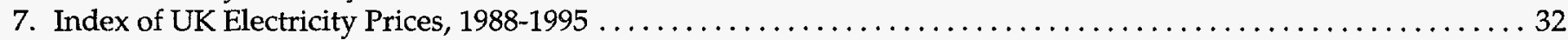

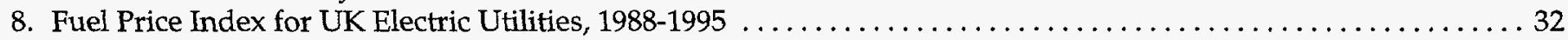

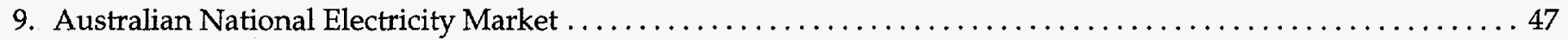

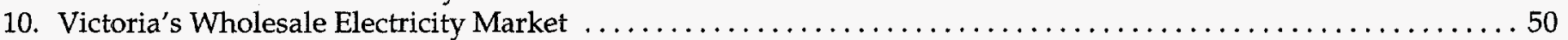

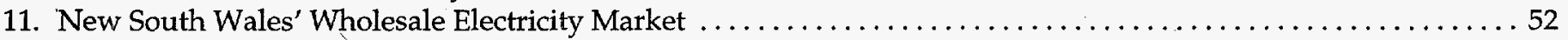

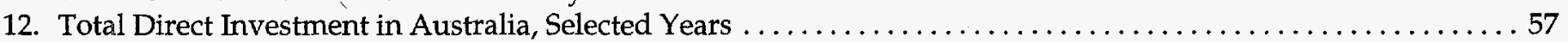

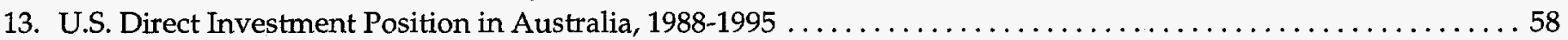

14. Argentine Federal Electricity Restructuring of Conventional Power Generation $\ldots \ldots \ldots \ldots \ldots \ldots \ldots \ldots 6$

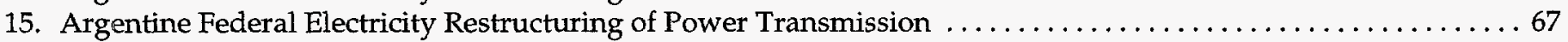

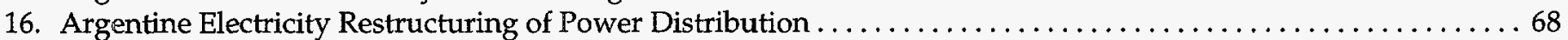

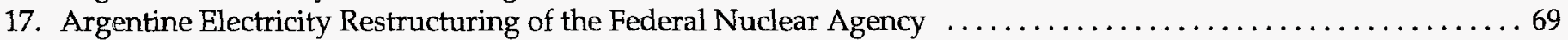

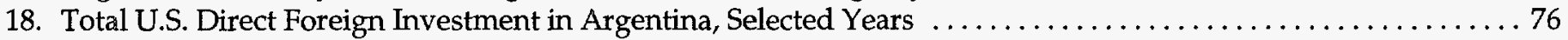

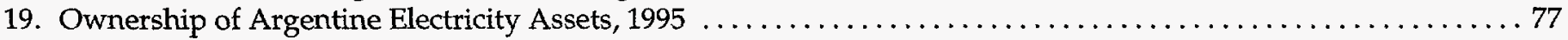

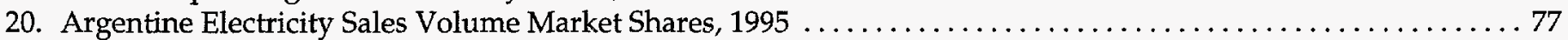




\section{Executive Summary}

Over the past decade a number of nations have restructured their electricity industries. Several nations have also significantly reduced the government's role in the ownership and management of domestic electricity industries-both at the state and at the national level. The Energy Information Administration selected Argentina, Australia, and the United Kingdom (UK) for this study partly because of the extent to which these nations have undergone electricity reforms but also because of the major role that U.S. companies have played as investors in these nations' reformed and privatized electricity sectors. Understanding how Argentina, Australia, and the United Kingdom each addressed the issues of primary importance to their country's electricity sector reform may be informative to those who will fashion the structure of similar reforms in the United States. This understanding may be all the more important because of the experiences that U.S. electric companies will have gained from their investments in these countries.

Since the early 1990 's, investment in overseas electricity assets has been a rapidly growing target of U.S. companies' foreign investment (see Figure ES1, and the

\section{Figure ES1. U.S. Direct Investment Position in Overseas Utilities}

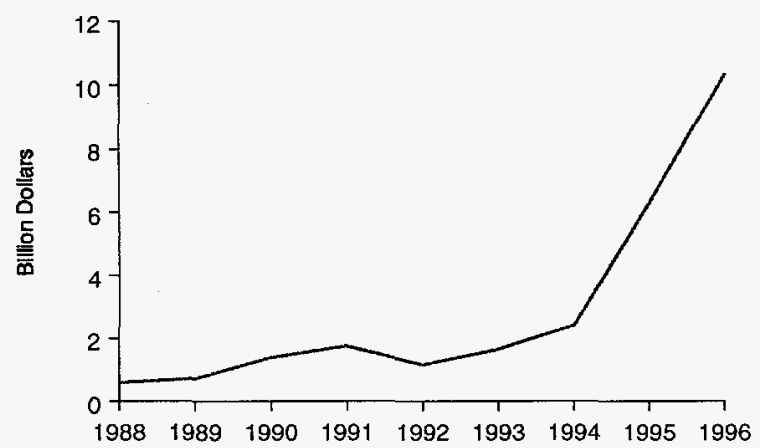

Note: These utilities include, in addition to electricity, natural gas distribution and sanitary services. However, the sharp upward climb in these investments during the years 1994 through 1996 is almost entirely due to overseas electric utility investments by U.S. companies.

Source: U.S. Department of Commerce, Bureau of Economic Analysis, Survey of Current Business, (Washington, DC), August, 1990-1997. box entitled "Two Methods of Calculating Foreign Investment" in Chapter 1). The predominant share of this investment has been directed at the United Kingdom and Australian electricity industries (Figure ES2). The investment expenditures of U.S. companies in the electricity industries of the United Kingdom and Australia alone far exceed all U.S. overseas electricity investment in the rest of the world combined. Electric utilities from the United States have also been the most prominent foreign investors in the recently-privatized Argentine electricity companies-although the dollar value of investment in Argentina's electricity industry has been smaller relative to the investment dollars flowing to Australia and the United Kingdom.

In Argentina, Australia, and the United Kingdom, electricity reform has involved a combination of the following issues:

- an unbundling of electricity assets;

- the creation of electricity pools;

- the creation of independent system operators;

Figure ES2. U.S. Direct Investment Position in Australian and UK Other Industries

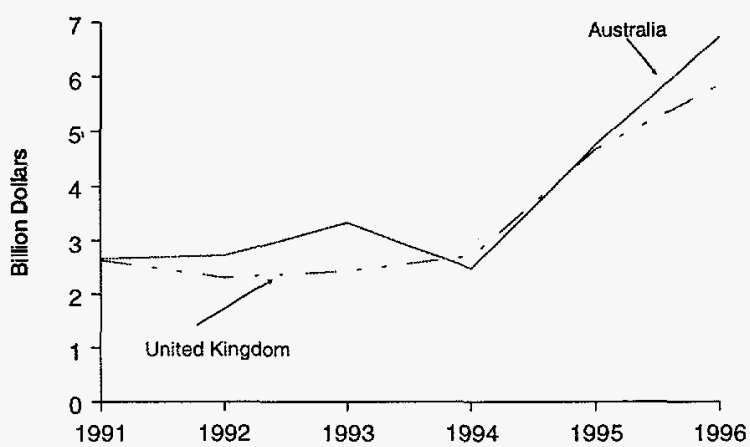

Note: The Commerce Department's "Other Industry" category includes several other industries in addition to electricity. However, the rapid growth in this overall industry category in 1994 through 1996 is affected most predominantly by U.S. company invesments in Australian and UK electric utilities.

Source: U.S. Department of Commerce, Bureau of Economic Analysis, Survey of Current Business (Washington, DC), August, 1993-1997. 
- the privatization of electricity assets through sale or public auction;

- the deregulation of electricity and the implementation of a more restrained form of regulation where regulation was retained;

- the adoption of price cap regulation and movement away from rate-of-return regulation;

- the realization of a competitive market in generation;

- the separation of the "wires" function of distribution from the "marketing" function;

- the gradual introduction of competition in electricity marketing;

- an opening up of domestic electricity assets to foreign investment; and

- determination of the degree of recovery of stranded costs.

In each of the three case study countries, issues surrounding electric industry restructuring, competitive electricity pools, privatization, deregulation, and stranded costs are unique to each country's electricity reform experience. However, there are often more commonalities than differences, particularly in the case of Australia and the United Kingdom. In all three countries, electricity reform involved a greater opening to foreign investment in electricity.

In Argentina, Australia, and the United Kingdom, electricity restructuring and privatization were carried out in an atmosphere of general economy-wide restructuring and privatization. In all three countries, a primary goal motivating electricity reform was to achieve lower electricity costs for consumers through encouraging efficiency improvements in the electricity industry. Reduced costs were also to serve the purpose of improving the efficiency of the overall economy. In all three countries, raising revenues for the treasury to reduce public borrowings was another overriding motive. In Argentina, obtaining badly needed capital for electricity infrastructure improvement and expansion was an additional motivating factor for reform and privatization.

In order to explain more fully how Argentina, Australia, and the United Kingdom each proceeded with the transformation of their electricity industries, these issues are discussed in detail (on a country-by-country basis) in the individual chapters of this report. However, the highlights of how each country chose to deal with these issues can be summarized as follows.

\section{Industry Restructuring}

Figure ES3 depicts a hypothetical "model" of what a national electric utility restructuring might look like. Figure ES3 shows an electricity industry as a single nationalized entity prior to the restructuring. The restructuring involved the separation of all electricity industry functions along separate lines of business (i.e., generation, transmission, distribution, and marketing) into newly created organizations. It should be stressed that Figure ES3 is a much simplified (and not entirely representative) model of restructurings that have taken place in several nations. Figure ES3 is more illustrative of the United Kingdom experience-where the electricity industry prior to restructuring was owned and managed primarily by the central government. In contrast, in Australia statewide electricity restructuring largely preceded nation wide reforms and was predominate. Argentina is also distinct in that Argentina's restructuring involved a widescale consolidation of electricity operations.

In the United Kingdom, electricity reform initially involved the complete restructuring (unbundling) of the industry along segmental lines: electricity generation, transmission, distribution, and marketing all became separate operations. Prior to privatization, the United Kingdom created two large power generation companies, one national transmission company, and twelve regional generation companies. A newly-evolving electricity marketing segment was to be gradually developed, where sales, brokerage, and billing operations each became a separate function. In its restructuring, however, the United Kingdom created an industry that from its infancy was dominated by the two large generation companies whose predominant market share-and predominant role in the electricity pool-has often given rise to concerns over whether generation was adequately competitive.

Although Australian reforms borrowed heavily from the UK experience, there have been several notable distinctions. In contrast to reform in the United Kingdom, electricity reform in Australia was undertaken several years later and at both the state and national levels. In general, several of the Australian state governments restructured their electricity industries in a fashion similar to the United Kingdom: separating generation, transmission, distribution, and supply into different operations. However, although Australia's reform efforts are more recent (and therefore more difficult to appraise), it appears that Australia may have avoided the kind of public concerns that have occurred in the United Kingdom over a lack of competition in electricity generation. Victoria, the second most populous of the Australian states-but with a population less than one-fifth that of 
Figure ES3. An Example of the Transformation of a National Electricity Industry to a Restructured Industry Along Functional Lines.

New Structure

Old Structure

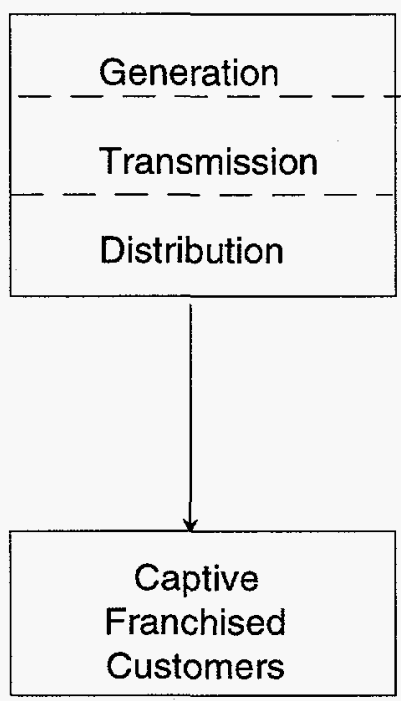

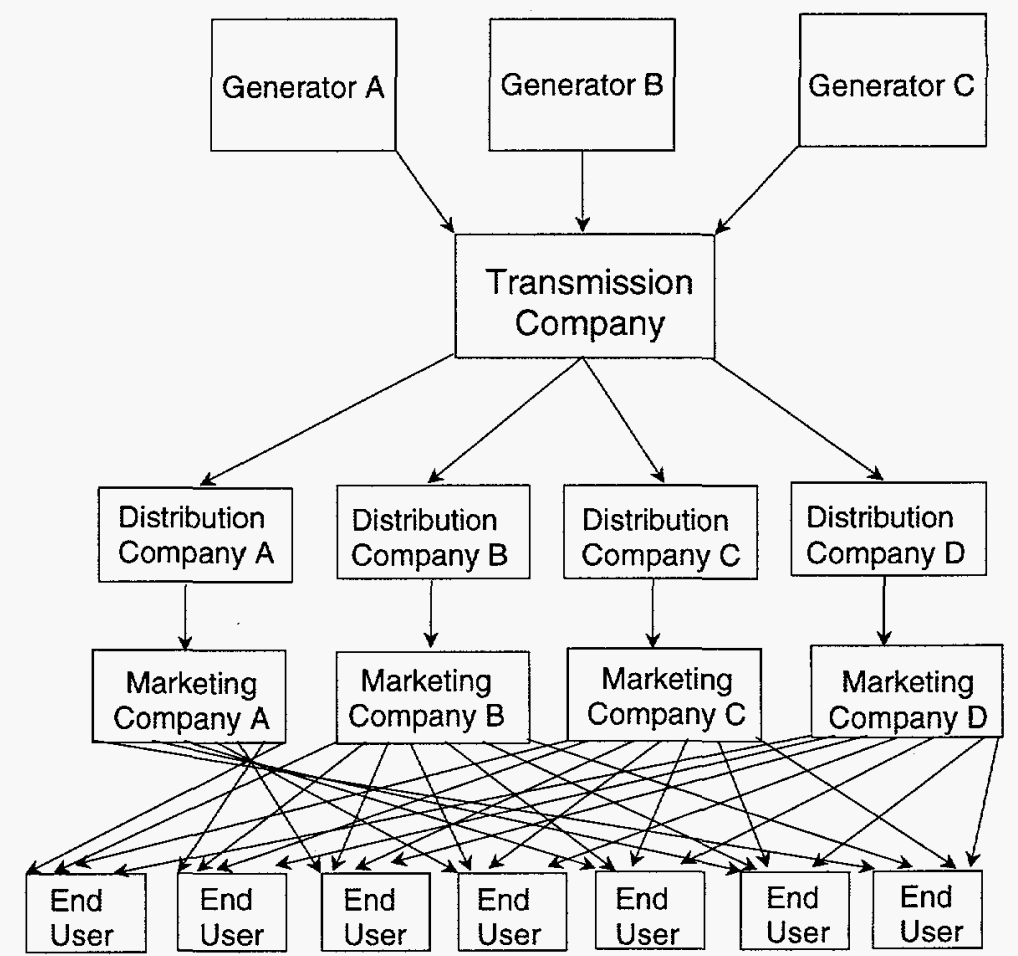

Note: The above examples do not represent any particular nation's electricity industry (either before or after restructuring). This diagram serves as a simplified model of what a generic restructuring might involve. Real examples are generally more complex. The manner in which Argentina, Australia, and the United Kingdom were restructured is explained in subsequent chapters.

the UK-attempted to create more competition in generation through the creation of five generation companies. Various Australian governments have also encouraged the development of an independent electricity marketing function, thus as in the United Kingdom allowing customers to bypass traditional distribution companies.

In Argentina, as in the United Kingdom, restructuring was primarily a central-government-led operation. The Argentine government unbundled generation operations from transmission and distribution. Electricity marketing, however, was not separated out as a distinct business company or operation. However, due to the dispersed population concentrations in Argentina, several regional transmission companies were created. The regional companies act as spurs connecting otherwise isolated areas to the main electricity grids.

\section{Competitive Electricity Pools}

All three countries created national electricity pools. The United Kingdom was first to create a national electricity pool, which has been in operation since 1990. The UK electricity pool is operated by the National Grid Company, which is also responsible for electricity transmission. The UK pool has generally operated efficiently, although concerns have been raised over its tendency to produce price volatility and an unfair playing field between electricity suppliers (again, primarily the two now-privatized dominant generation companies) and electricity consumers. A secondary market, called a contract for differences market, has evolved in the United Kingdom. This secondary market allows participants to hedge a large fraction of their pool purchases.

In Australia, the National Electricity Pool was largely based on the UK model, but with some noteworthy 
variations. The Australian National Pool is a fairly recent operation, having started in May 1997. (Preceding the creation of the national pool, a couple of Australian state governments created their own electricity pools and these have been in operation for several years.) The Australian National Pool is operated by an independent system operator, the central-government-owned National Electricity Market Management Company, which is separate from any transmission operation. As in the United Kingdom, pool price volatility has been an important concern in Australia, and a contract for differences market has been created to manage this risk. However, due to the relatively large number of generators participating in the supply end of the business, less concern has been raised over a lack of competitiveness.

In Argentina, a national electricity pool was also based upon the UK model. Pool operations began in 1992, and pool prices have been considerably beneath the comparable wholesale price of electricity existing prior to the commencement of pool operations. Again in contrast to the United Kingdom, no generator in Argentina is allowed to control more than ten percent of the system's generation capacity. ${ }^{1}$ Further, in Argentina an independent system operator operates the pool.

\section{Asset Privatizations}

In the United Kingdom, widespread privatizations of electricity assets followed shortly after the restructuring. These privatizations were achieved through public auctions. Eventually, virtually the entire UK electricity industry was privatized with the exception of some relatively old nuclear generation plants. Much controversy surrounded the sale of UK electricity assets. With the exception of the sale of nuclear assets, UK electricity auctions were oversubscribed, leading to allegations that the government had not obtained a fair value in the sale of public goods. Further, energy companies from the United States were eventually to acquire roughly one half of all UK electricity assets.

In Australia, only the state of Victoria has gone nearly as far as the United Kingdom in its privatization efforts. Other Australian state governments were either slower to privatize or decided to retain ownership while reducing control over their electricity industries. During the initial public auction of Victoria's electricity assets, U.S. companies purchased controlling interests in all five of the privatized regional distribution companies and three of the five generation companies. Sizable premiums over book value were paid in all cases, an indication of the relatively high value U.S. companies placed on these takeover targets.
The Argentine central government also employed an auction to transfer ownership of the national government's holdings in electricity companies to the private sector. Interestingly, in the Argentine auction, bidders were required to submit levels of service standards they were committing to meet along with bid prices. Again, U.S. companies were the dominant foreign investors in Argentine electricity.

\section{Deregulation}

All three governments employed a less intrusive form of regulatory authority than that which had existed in the past. The United Kingdom's electricity reform efforts embraced two fairly radical departures from previous electricity regulation. One involved the nature of the regulator. One of the first acts of electricity reform created a national electricity body, the Office of Electricity Regulation (OFFER). In order to reduce regulatory costs and allow industry more discretion in investment and operational matters, the OFFER was lightly staffed and was headed only by a single individual (not a commission). Similar institutions were adopted in Argentina and Australia.

A novel form of price-cap regulation was adopted in the United Kingdom and emulated in Argentina and Australia. Price-cap regulation attempts to restrain costs via the application of price ceilings. Price-cap regulation is a marked contrast to the rate of return regulation employed in the United States. In terms of encouraging efficiency, price-cap regulation appears to have been successful in all three nations but has become a highly controversial matter with regard to whether it promotes equity and fairness for consumers.

\section{Energy Subsidies and Stranded Costs}

In the United Kingdom, the issue of energy subsidies (mostly those related to coal) and the disposition of stranded costs (mainly nuclear-related) greatly complicated efforts at electricity privatization. The UK electricity industry had long sustained the UK coal industry through its purchases of domestic coal at highly inflated prices. As both industries became privatized and deregulated, these subsidies were severely reduced. The stranded costs associated with nuclear power investment in the United Kingdom represent the difference in the book value of nuclear power facilities and the market value of these facilities. In contrast to the situation in the United States, where the issue of who should bear the 
burden of stranded costs associated with nuclear power investments is between rate payers and shareholders, in the UK (where, prior to privatization, all nuclear generating assets were owned by the national government), the issue of allocating the burden of stranded costs was between rate payers and tax payers. In the end, both parties paid: tax payers through the government's auctioning off nuclear electricity assets at heavily discounted prices; and rate payers, through a nuclear surcharge attached to electricity bills.

In Australia, stranded costs were largely unimportant due to Australia's having a very competitive coal industry (by world standards) and never having developed a nuclear power industry. In Argentina, much as in the United Kingdom, part of the failure to successfully privatize the federal government's nuclear plants stemmed from the issue of stranded costs. However, unlike the United Kingdom, Argentina has had to resolve stranded costs associated with past investments in hydroelectric power as well. Even though the marginal costs of operating Argentina's two large binational (i.e., jointly held with Paraguay and Uruguay) hydroelectric facilities are low, it is doubtful that the Argentine government will be able to recover the large capital costs associated with these facilities because of their large construction cost overruns. 


\section{Endnotes}

1"Reshaping Power Markets: Lessons from South America," The Electricity Journal (March 1996), p. 65. 


\section{Chapter 1}

Electricity Reform Abroad: Experiments in Argentina, Australia, and the United Kingdom

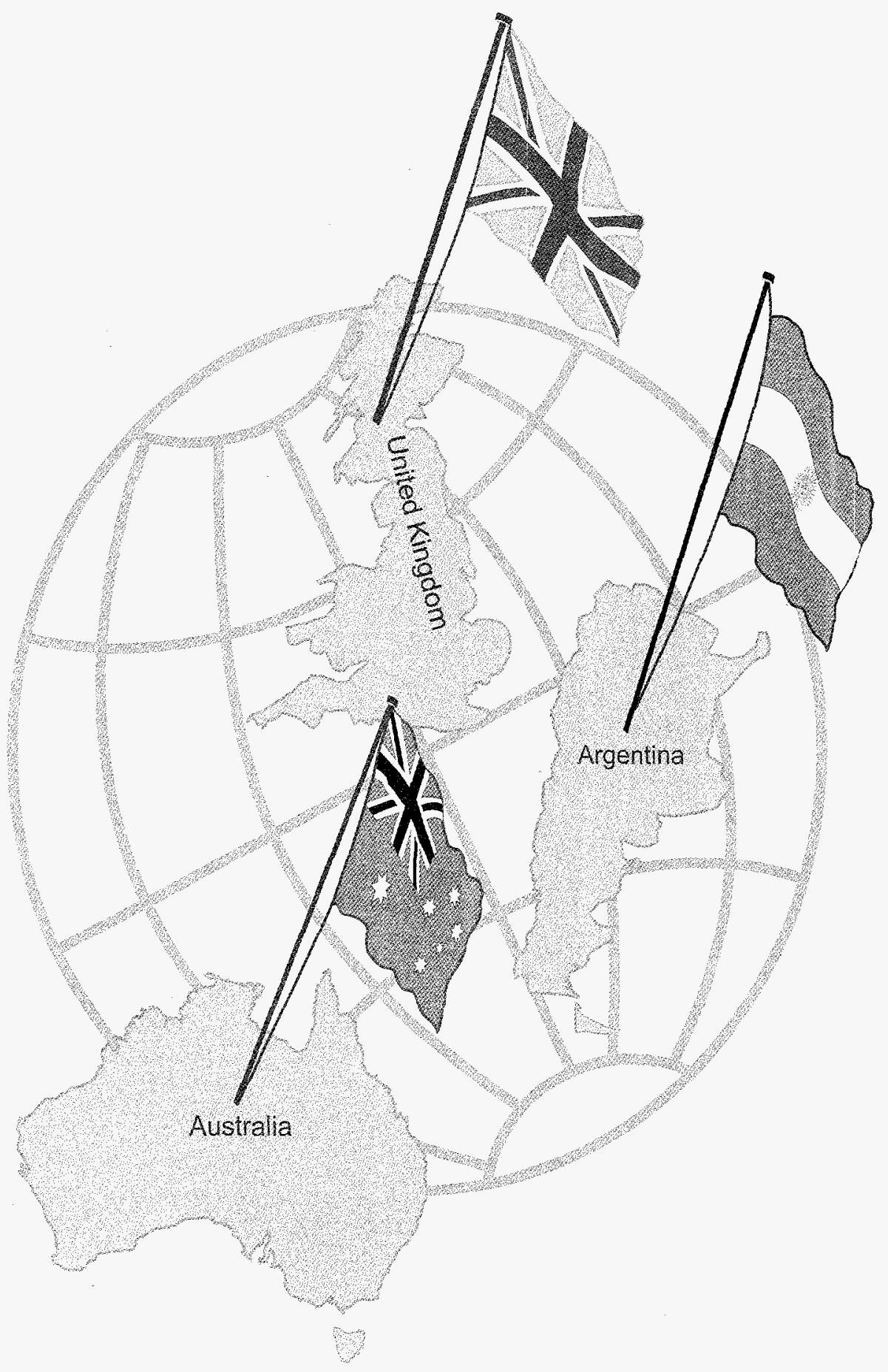




\section{Electricity Reform Abroad: Experiments in Argentina, Australia, and the United Kingdom}

Over the past few years, several nations have initiated electricity industry reform and privatization efforts. Argentina, Australia, and the United Kingdom (UK) are among those countries at the forefront of such efforts. ${ }^{1}$ Reforms undertaken in these three countries are especially important because they have in many ways become models for reforms carried out elsewhere. From the perspective of the United States (and other countries considering electricity reform), these three nations are often viewed as laboratories in which the efficacy of particular electricity reform policy choices are being tested. For this reason, we have referred to these reforms as "experiments." In reality, however, these reforms represent firm policy measures adopted by the countries involved.

This report reviews and analyzes the recent electricity reforms in these countries in an attempt to better understand how different models of privatization and reform have worked in practice. (For a more general discussion of some of the factors underlying the recent worldwide trend toward industry privatization, see the box entitled "Why Privatize?")

This report also analyzes the motivations of the U.S. companies who have invested in the electricity industries of Argentina, Australia, and the UK. These countries have become the largest targets of U.S. foreign investment in electricity. American electricity investment in the newlyprivatized electricity industries of Australia and the UK far exceeds all other U.S. electricity investment abroad. Companies from the United States were also the largest investors in Argentina's recently-privatized electric utility industry.

This report utilized two calculations of foreign investment. One is the foreign direct investment series produced by the U.S. Department of Commerce. The other is based on transactions (compiled from the financial press) in Argentine, Australian, and U.K. electric utilities. For a comparative discussion on both methods, see the box entitled "Two Methods of Calculating Foreign Investment."
The electricity reform and privatization experiences reviewed in this report may offer some insight as to how the U.S. electricity industry might develop as a result of recent domestic reform efforts and deregulation at both the state and national levels.

\section{The Characteristics of Individual Country Reforms}

To a large extent, Argentina's and Australia's electricity reforms were guided by reforms undertaken earlier by other countries: Australia benefitted from the United Kingdom reform efforts, and Argentina benefitted from the UK, and from Chile's reform initiatives. However, the particular electricity reforms in the three case-study countries were also guided by each country's unique governmental structures and institutions, and by such characteristics as demographics, economic and political environments, and resource availability. These factors are discussed briefly below and in more detail in the chapters devoted to each of these countries.

A unitary, centralized form of government exists in the United Kingdom. Governmental authority originates in the crown. At the time that the United Kingdom embarked upon electricity reform, all policy decisions were made at the national level. Electricity reform in the United Kingdom was therefore carried out entirely by the ruling (conservative) political party, which placed a strong emphasis on aggressively privatizing electricity-as well as several other major industries.

In contrast, both Argentina and Australia have a federalist form of government (similar to that in the United States) which is more oriented to regional, or state authority. ${ }^{2}$ In contrast to the United Kingdom (but, again, very similar to reform efforts in the United States), electricity reform efforts in Argentina and Australia have had both a national and a state component.

Electricity reform in Australia was initially carried out by separate state governments with different ruling political 


\section{Why Privatize?}

Privatization has in part been driven by the increasing globalization of the world economy. Several decades of rapid growth in intemational trade and investment have made competitiveness in international trade an essential factor in a nation's ability to create jobs, raise real wages, and generate wealth.

For many nations, privatization has become the only effective method of raising investment capital on favorable terms. High levels of past public sector borrowing have saddled many nations with large levels of debt. As a consequence, these nations have had little recourse but to sell state assets to reduce debt and to generate revenue.

Various businesses besides electricity have been privatized. Indeed, the largest privatization to date has been the sale of Japanese Telecom for $\$ 73$ billion. In the United Kingdom public housing has been privatized and, in the United States, many municipal services, such as waste disposal, have been privatized.

Although privatization efforts differ substantially from country to country, there is a strong common economic rationale underlying the various decisions to privatize state energy resources. In general, nations have privatized state-owned electricity industries to achieve one or more of several objectives. These objectives include: 1) raising revenue for the state; 2 ) raising investment capital for the industry or company being privatized; 3) reducing government's role in the economy; 4) promoting wider share ownership; 5) increasing efficiency; 6) introducing greater competition; and 7) exposing firms to market discipline. ${ }^{a}$

Privatization is closely connected with the development of the international energy company-a company whose focus is becoming both more global and more multi-purpose. Until recently, outside of the world's few major integrated oil companies, only a handful of energy companies were considered multinational. Currently, in addition to the scores of petroleum companies that can now be classified as multinational, the scope of many coal companies, petroleum pipeline companies, electric utilities, and power generation equipment and construction companies has become increasingly global. Through consolidations, mergers, acquisitions, and strategic alliances, the world's energy companies have become both more integrated and more multinational. Oil and gas companies have become electricity companies; domestic regional electric utilities have become multinational electricity companies; electricity distribution companies have become generation companies; and generation companies have become distribution and transmission companies.

"The objectives of privatization listed above appeared in "Privatization: Learning from the UK Experience" (London, UK), Price Waterhouse, 1989. However, objective number two, "to raise investment capital for the privatized industry or company," was added by the authors of this report.

parties, resulting in significant variations among the states. For instance, reform in the state of Victoria has, in general, emphasized privatization of electricity, while corporatization ${ }^{3}$ has been emphasized in the other states. Further, each Australian state has restructured its electricity industry to a different extent, and each state has permitted a different degree of foreign investment. As a result of the variety of state-implemented reforms, Australia's movement towards a national electricity market has been more complicated than that of the United Kingdom. ${ }^{4}$ A national electricity pool began in May 1997, although the states initially participating were concentrated in the southeastern portion of the country.

Argentina's constitution (based upon the U.S. constitution) resulted in a federalist form of government very similar to that of the United States. However, the federal government in Argentina has been a more forceful catalyst in advancing electricity reform than the Federal government in the United States.
The form of government existing in each of these nations also determined which level of government would achieve the largest financial gains from privatization. In Australia, state governments were able to erase large deficits through the sell-off of electricity assets. In Argentina and the United Kingdom, it was the national government that took in the receipts from such sales.

A commitment to free market economics is also a relatively more recent development in Argentina than in Australia and the United Kingdom. In the latter two nations, this commitment was not only made earlier, but has generally strengthened in recent years. Argentina's former heavy state hand in the national economy (and its past industry nationalizations) continue to taint it with a reputation as a relatively high-risk investment country. Argentina's current political instability also casts doubt upon the durability of its reforms and its creditworthiness. Further, Argentina is different from Australia and the United Kingdom in that Argentina is a developing nation 


\section{Two Methods of Calculating Foreign Investment}

This report employed two methods to calculate U.S. companies' investments in foreign electricity. Both methods have their advantages and disadvantages. Figure ES1 is based upon foreign direct investment ${ }^{\mathrm{a}}$ data reported by the U.S. Department of Commerce. Foreign direct investment (FDI) data has several benefits--one of which is to provide a historical perspective for recent overseas investments in overseas utilities. In 1996, the U.S. Department of Commerce reported that the U.S. foreign direct investment position in all overseas utilities totaled $\$ 10.3$ billion. The use of a consistent statistical time series--such as the FDI data--allows the reader to see (as shown in Figure ES1) that the total electricity investment value has grown considerably in recent years.

However, as with most statistical data series, the foreign direct investment data have some limitations. For instance, these data combine other smaller utility investments (natural gas, sewage, and water) with electric utility investments, and do not provide country-specific detail. Also, the FDI data currently run through the year 1996, and, due to a reporting lag, may not include some of the largest and most recent transactions. Further, FDI data measures net financial flows between parent and foreign subsidiaries, and industry classifications of foreign-affiliated companies could ascribe some electricity investment activity to nonelectricity industries. Therefore, although the FDI data are useful for a time-series perspective, the factors just discussed may complicate the interpretation of FDI statistics, and the absence of 1997 transactions may cause the FDI data to underestimate total U.S. electricity investment.

For these reasons, the individual country chapters of this report (chapters 2, 3, and 4) employ a different and more detailed method of calculating U.S. company investment in foreign electricity. This method involves a review of individual company foreign electricity investment transactions reported in the financial press, and avoids some of the limitations of the DIA statistics; but, it is not without its own problems. In some cases, transaction data can overstate the extent of U.S. company investment. For instance, where individual transactions involve a consortium of U.S. and foreign companies, and the U.S. is the lead investor (but specific company investment shares are unknown), the entire investment's value may be counted as the value of the U.S. company's investment. Also, transaction data often report investment commitments, instead of actual expenditures. Nonetheless, the transaction compilation data (including transactions occurring in 1997) show that, since 1993, U.S. companies have committed over $\$ 44$ billion to the purchase of electric utility assets in Argentina, Australia, and the United Kingdom (UK) alone. The UK leads as a target of U.S. company investment with over $\$ 25$ billion committed thus far. Australia follows with a little under $\$ 15$ billion in commitments, and Argentina with roughly $\$ 4$ billion. (For greater detail on U.S. company committed investments in Argentina, Australia, and the UK's electric utility industries, see chapters 2, 3, and 4.)

${ }^{a}$ The U.S. Department of Commerce, the agency which collects data on FDI, measures FDI as the book value of foreign direct investors' equity interest in and net outstanding loans to their U.S. affiliates. The Department of Commerce defines a U.S. affiliate as a U.S. business enterprise in which one foreign direct investor owns 10 percent or more of the voting securities or the equivalent.

${ }^{\mathrm{b}}$ For example, a large repayment in the reporting year to a parent company of debt incurred in an earlier acquisition can reduce FDI, even though FDI-related acquisition activity may have increased substantially in the reporting year.

cFor example, a highly diversified company's overseas' investments in electric utilities might be registered under its primary standard industrial code (SIC) classification, which may be wholly unrelated to electricity.

where past investment in electricity has been insufficient. In contrast to the situation in Australia and the United Kingdom, electricity is expected to be a growth industry in Argentina, although funding such growth may be beyond the capabilities of the domestic capital market. As a consequence, while attracting foreign investment has been a less important factor in electricity reform and privatization in Australia and the United Kingdom, it has been a high priority in Argentina.

Since the implementation of electricity reform, Australia and the United Kingdom have both experienced a surge in foreign investment in their electricity sectors. Despite its higher-risk profile, Argentina has also experienced a considerable increase in foreign investment in the electricity sector. Since 1995, U.S.-based companies have acquired eight out of twelve recently-privatized electricity distribution companies in the United Kingdom. In the aggregate, the value of these acquisitions was roughly $\$ 15$ billion. In the Australian state of Victoria, all five of the recently-privatized electricity distribution companies were purchased by U.S. companies. Moreover, U.S.-based companies have purchased shares in three of five recently-privatized Victorian electricity generation companies. In Argentina, U.S. companies have also been the largest foreign investors in electricity.

For other reasons, Argentina is probably the most anomalous of the three countries. Both Australia and the United Kingdom are included among the world's 
industrialized (or post-industrialized) economies. In both nations, electricity is a mature industry and future growth in electricity consumption is expected to trail Gross Domestic Product growth rates. Both countries have wellestablished capital markets and both countries had, prior to privatization, invested ample funds in their electricity industries.

Another important distinction between the three countries concerns stranded costs. ${ }^{5}$ In Argentina and the United Kingdom, the issue of stranded costs (mostly those related to nuclear investments) greatly complicated electricity reform. In Australia (which shunned nuclear power from the beginning), stranded costs were not an issue. Australia also had a relative advantage in that its coal industry is highly efficient by world standards. In contrast, sustaining an uneconomic coal industry became another source of stranded costs in the United Kingdom.

Different demographic and geographic characteristics have also influenced the structure of the electricity industries in Argentina, Australia, and the United Kingdom. Population density in the United Kingdom is fairly high and relatively concentrated in dispersed urban areas, a fact which more readily allows for the establishment of a national transmission grid (which the United Kingdom had even prior to its current era of electricity reform). In Australia, population density is in general sparse, with the exception of the southeastern portion of the country. As a result, the establishment of an operational Australian national grid in 1997 in its initial phase was limited geographically to the southeastern portion of the continent. Currently, only New South Wales, Victoria, South Australia, and the Australian Capital Territory are interconnected. Historically, there has been little interstate trade in electricity. Argentina is similar to Australia in that its overall population density is low, but there is a high population concentration in a relatively small area. In Argentina, one third of the nation's 13 million people reside in the Buenos Aires area. As a result, the development of an Argentine national grid has been piecemeal and is still incomplete.

In all three countries, greater economic efficiencies in electricity supply were important privatization goals. Productivity was seen as being especially important in Argentina, given that it had a particularly inefficient electricity industry. In retrospect, however, the massive reduction of the Australian and UK electricity industry workforce in recent years (which occurred at the same time as electricity production rose) indicates that the electricity industries of these countries were substantially overstaffed. Since the implementation of reform and privatization measures, electricity prices in all three countries have either declined or have lagged behind overall inflation, even though both Australian and UK electricity prices prior to privatization were within the bounds of the electricity prices of other industrialized countries. ${ }^{6}$ The overall financial performance of the electricity industries in each of the three countries has generally improved subsequent to reform and privatization.

No country has embarked upon a more ambitious and extensive program of electricity privatization and reform than the United Kingdom. In Argentina, state-wide reform has clearly lagged reform at the national level, and the degree to which electricity assets have been privatized has not been as extensive as in the United Kingdom. In contrast, reform in Australia has been more ambitious in the state of Victoria and less ambitious in the other states and at the national level. Nonetheless, all three countries have opened their electricity industries to foreign investors. Further, in all three countries, U.S.-based electric utilities have been the most prominent among foreign investors. In particular, a handful of U.S. utilities have been especially aggressive in investing in recently-privatized electricity companies in Argentina, Australia, and the United Kingdom. In several cases, the same U.S.based utility has invested in electric utilities in two of the three countries.

\section{The Characteristics of Investing Companies}

The Energy Policy Act (EPAct), passed in 1992, liberalized the rules governing U.S. utility investment in electricity assets abroad. Somewhat over 20 U.S. companies, nearly all publicly-traded electric utilities, have acquired assets in either Argentina, Australia, or the United Kingdom in recent years. However, a large majority of publiclytraded electric utilities have chosen not to invest abroad. Insights as to the motivations for foreign investments in electricity can be gained by contrasting the characteristics of U.S. electricity companies investing abroad with other U.S. electric utilities.

The companies with electricity investments in Argentina, Australia, and the United Kingdom, through 1996, are listed in Table 1. This group of companies was compared to the group of all other publicly-traded companies classified as electric utilities (86 in number) (Appendix A).

Overall, the U.S. electricity companies that have invested in foreign electricity assets in Argentina, Australia, and the United Kingdom appear to have followed a strategy of more rapid corporate growth compared to other electric utilities. Based on net fixed assets (the value on companies' balance sheets of property, plant, and equipment adjusted for depreciation), foreign investing utilities grew at a 2.7-percent annual rate from 1987 through 1992 
Table 1. U.S. Utilities With Foreign Investments

\begin{tabular}{l}
$\quad$ U.S. Utility \\
\hline American Electric Power \\
Calenergy Inc. \\
Central \& South West Corp \\
Cinergy Corp \\
CMS Energy Corp \\
Dominion Resources Inc \\
Duke Power Co. \\
Edison International \\
Enron Corp \\
Entergy Corp \\
GPU Inc \\
Houston Industries \\
Northeast Utilities \\
Northern States Power \\
PacfiCorp \\
PG\&E Corp \\
Public Service of Colorado \\
Southern Company \\
Southwestern Public SVC Co \\
Texas Utilities \\
\hline
\end{tabular}

Source: Standard and Poors Compustat, July 1997.

(the year EPAct was passed), and at a 3.4- percent rate since then.$^{8}$ Other electric utilities, overall, grew at annual rates of 1.5 percent and 1.0 percent over the same periods, respectively. Unfortunately, data limitations prevent an assessment of the role of foreign investment in the growth in assets. ${ }^{9}$

The higher growth rates of electric utilities investing abroad reflect the higher growth rates of the domestic areas they serve. Over 50 percent of the sales of the foreign investing group are based in the more rapidly growing states of the Pacific Coast and Southwest (Figure 1). By contrast, over 70 percent of the total sales of other electric utilities were in the slower growing Northeast and Midwest areas.

Until recently, growth in the asset base of the foreign investing group appeared to come at the expense of dividend payouts to shareholders. Figure 2 shows that until 1990, the share of cash flow from operations (sometimes called internal cash flow) paid out as dividends averaged less than 40 percent compared to over 45 percent for other electrical utilities overall. However, since 1991, dividend payout for both groups has declined, so that by 1996 both groups were allocating about 36 percent of cash flow to dividends.
Figure 1. Regional Distribution of Sales for Foreign Investing Electric Utilities and Other Electric Utilities, 1995

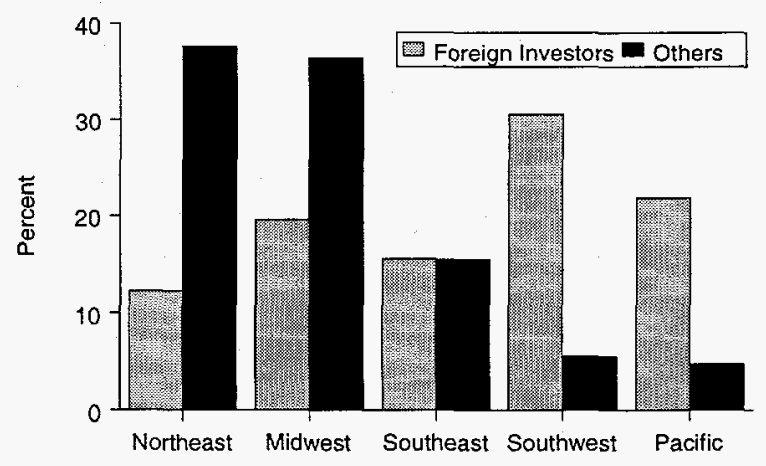

Source: Standard and Poors, Compustat.

Figure 2. Dividend Payout Ratio of Foreign Investing Electric Utilities and Other Electric Utilities, 1987-1996

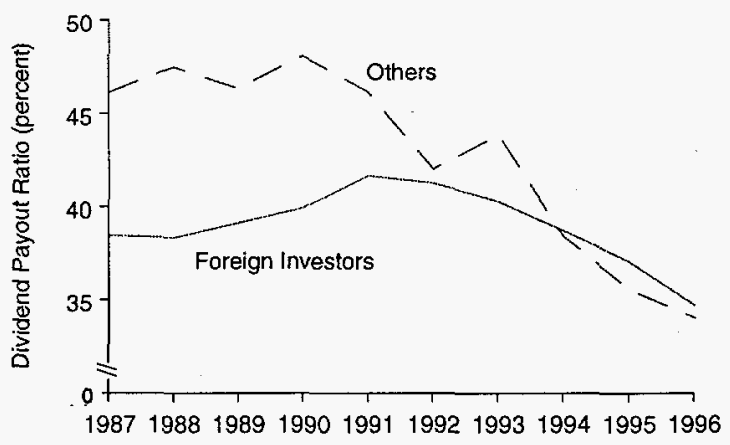

Note: Dividend Payout Ratio = Cash Dividends as a Percent of Cash Flow.

Source: Standard and Poors Compustat.

Despite the relatively smaller dividend payout, shareholders appear to have increasingly favored the electric utilities that have invested abroad (Figure 3). A useful measure that tends to reflect investors' views of a company's earnings prospects is the market-to-book ratio. The market-to-book ratio is the market value of a company's common shares divided by stockholders' equity. Stockholders' equity is assets minus liabilities as carried on a company's balance sheet and represents the book value of ownership in the company. As stated in a popular finance textbook, "the ratio of market-to-book value... will be a good measure of the value created by the firm for its shareholders because it equals the present 
Figure 3. Market-to-Book Ratio for Foreign Investing Electric Utilities and Other Electric Utilities, 1987-1996

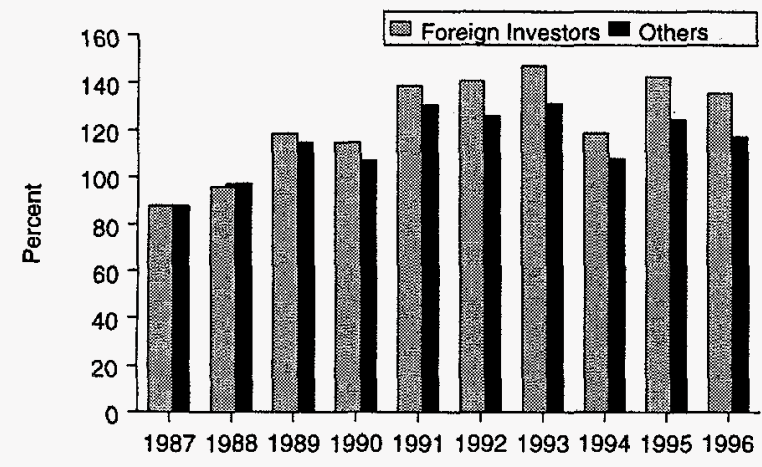

Note: Market-to-Book Ratio = Market Value of Common Shares as a Percent of Stockholders' Equity.

Source: Standard and Poors Compustat.

value of the dollars that stockholders receive for each dollar they invest in the business."

Figure 3 shows the market-to-book ratios for the two groups of U.S. electricity companies (those that invested abroad, and those that did not) over the 10-year period 1987 to 1996 . In 1987, the year in which stock prices crashed, the market value of each of the groups was only 88 percent of book value. Since then, the difference in the market-to-book ratio between the foreign investing group and other U.S. electric utilities has widened. The percent difference increased sharply in 1992, from 6 percent in 1991 to 12 percent, and in 1995 and 1996 the difference grew to 15 percent.

This latter pattern appears, at least in part, to reflect investors' heightened economic expectations for what turned out to be the companies that invested in electricity assets in Argentina, Australia, and the United Kingdom. There are at least two reasons for this view. First, the difference in profitability of the two groups generally narrowed after 1991. Figure 4 presents an often-used measure of realized profitability, i.e., return on equity (the ratio of net income to stockholders' equity), for the two groups of companies. Although the foreign investing group's return on equity was noticeably greater in the 1987-to-1991 period, the difference in the market-to-book ratio grew most in the 1992-to-1996 period when the difference in return on equity between them and the other U.S. electric utilities virtually disappeared. That is, investors' expectations of differences in future profitability, as reflected in the market-to-book ratios, were growing even as the differences in current profitability were shrinking. Second, although the market-to-book ratio for electric utilities in total fell somewhat after 1993, the difference between the foreign investing group and the other U.S. electric utilities was at a maximum in 1995 and 1996, the years of peak investment in electricity assets abroad, thus far.

In summary, the U.S. electricity companies investing in electricity assets made available through privatization in Argentina, Australia, and the United Kingdom have pursued a strategy of corporate growth, compared with other U.S. electric utilities overall. The foreign investing group had a history of corporate growth prior to the passage of EPAct in 1992 and have since continued to grow, at least in part, through investment abroad. ${ }^{11}$ Although corporate growth may have reduced dividend payout to shareholders, investors overall appear to favor the strategies of the foreign investors compared with the strategies of other electric utilities.

\section{Figure 4. Return on Equity of Foreign Investing Electric Utilities and Other Electric Utilities, 1987-1996}

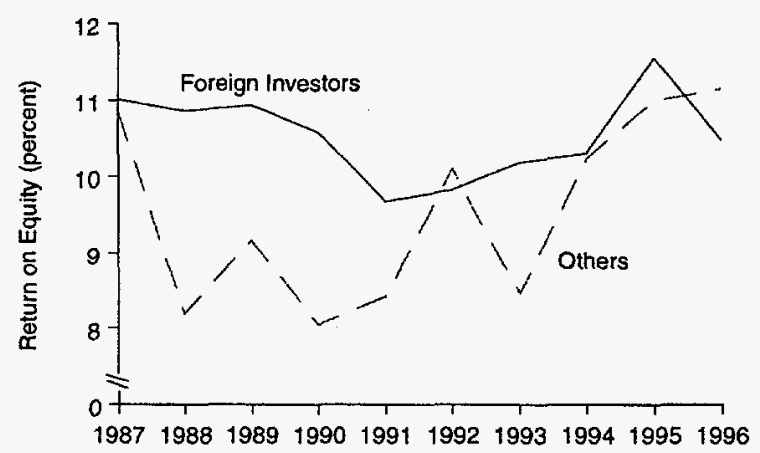

Note: Return on Equity $=$ Net Income as a Percent of Stockholders' Equity.

Source: Standard and Poors Compustat. 


\section{Endnotes}

${ }^{1}$ In an earlier Energy Information Administration report, entitled: Privatization and the Globalization of Energy Markets, EIA presented from a global perspective an analysis of energy privatizations developments by country and by energy sector. This study included a section on regional reform and privatization of electricity markets. This current report takes a more detailed look at three countries where electricity reform and privatization have been at the forefront of such efforts globally.

${ }^{2}$ The Commonwealth of Australia, consists of six states and two territories.

${ }^{3}$ Corporatization, as defined in Sally Hunt and Graham Shuttleworth's "Competition and Choice in Electricity," as "the formal and legal move from direct government control to a legal corporation with separate management. This may be a government-owned corporation."

${ }^{4}$ However, an interesting byproduct of state-based reform effort is that it has induced a form of policy competition between states and a sort of follow-theleader type of reform. For instance, during the initial period of nationwide electricity reform, the most populous Australian state, New South Wales, was opposed to fully privatizing its electricity sector, but later eventually became resigned to do so as it became clear that this would enhance New South Wales electricity industries' ability to compete in a national market with privatized electricity companies.

${ }^{5}$ Stranded costs are frequently defined as the value of unamortized investments in electricity assets that could not be recovered in a competitive marketplace or the difference between market value and book value of these assets

${ }^{6}$ In all three countries, some of the decline in electricity prices can be traced to lower fuel costs. However, a portion of the price decline can also be attributable to the substantial non-fuel operating cost reductions made by these industries subsequent to their reform.

The data are taken from filings of Form 10-K with The Securities and Exchange Commission as compiled by Compustat, a service of Standard \& Poors. ${ }^{8}$ Compustat, Standard and Poors (1997).

${ }^{9}$ Only 6 of 20 companies separately reported domestic and foreign assets in 1996.

${ }^{10}$ Alan C. Shapiro, Modern Corporate Finance (New York: Macmillan Publishing Company, 1990), p. 335.

${ }^{11}$ Compustat, Standard and Poors (1997). 



\section{Chapter 2 \\ Electricity Restructuring and Privatization in the United Kingdom}

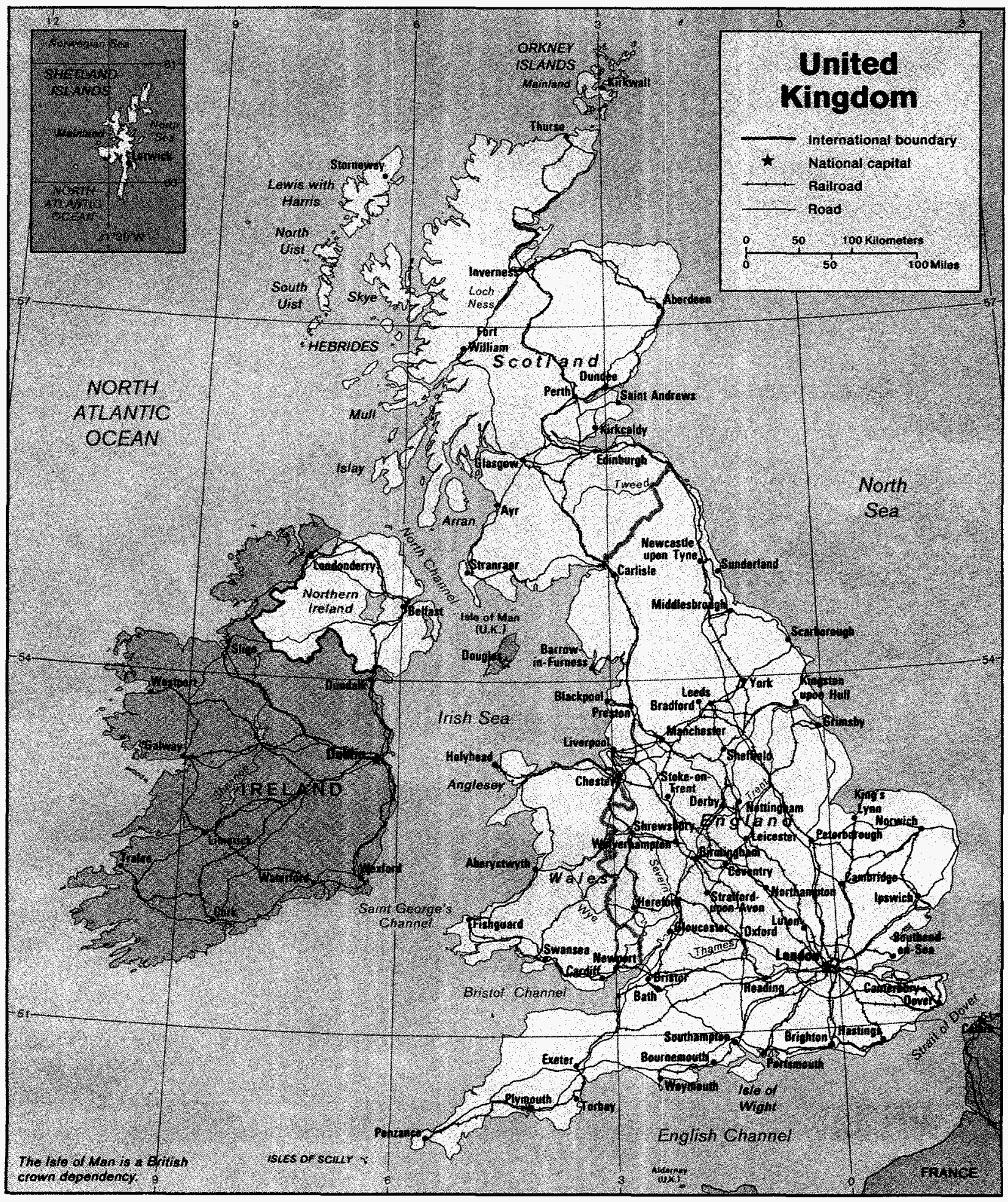




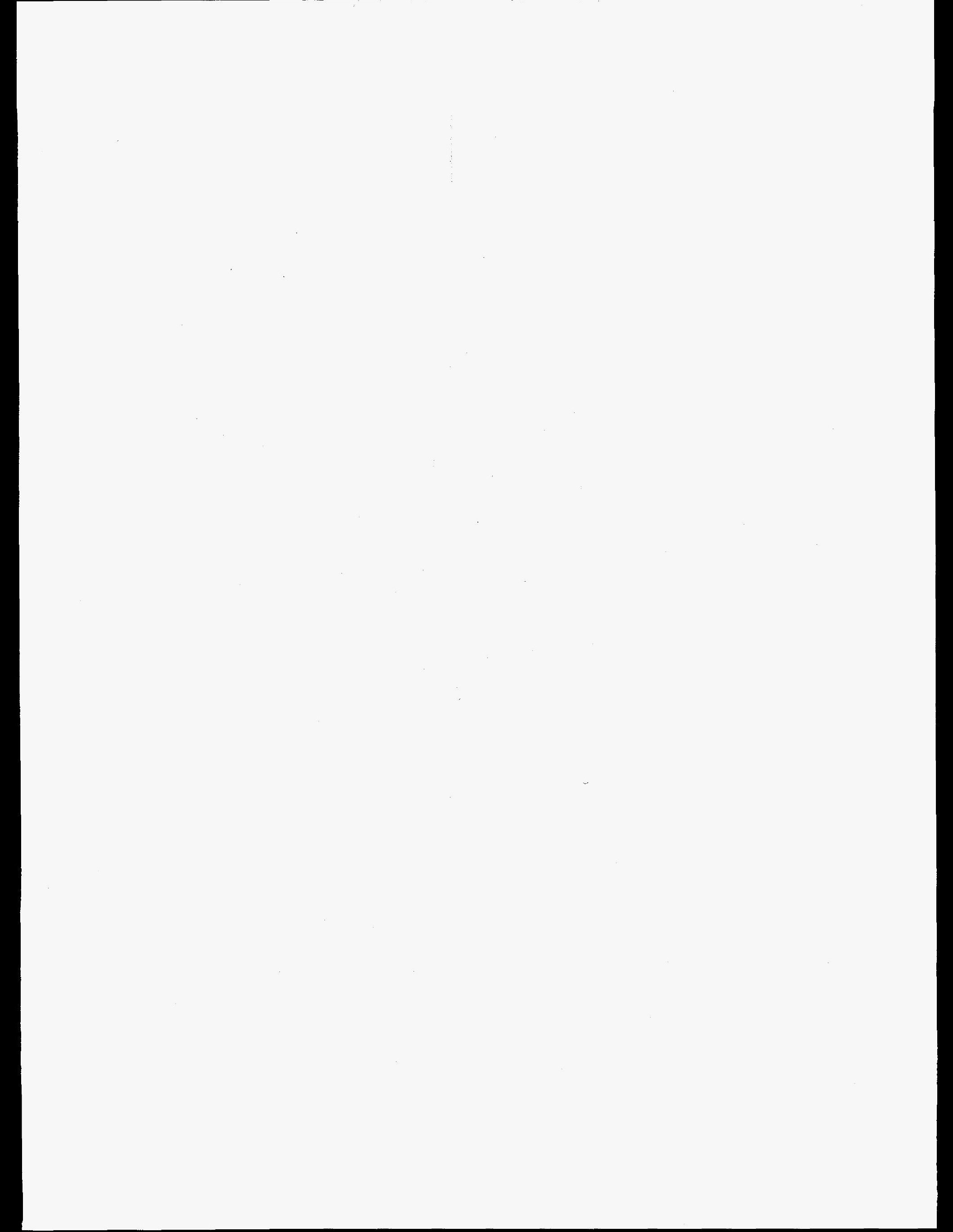




\section{Electricity Restructuring, and Privatization in the United Kingdom}

The United Kingdom (UK) offers an interesting case study into the process of electricity industry restructuring, privatization, and regulatory reform. The United Kingdom was one of the first nations to embark upon widespread privatization of its electric utilities. Although a growing number of nations have privatized their electricity industries since (or are currently undertaking such efforts), the UK's electricity privatization reform efforts have been among the world's most ambitious and path breaking. Several other nations have subsequently followed their example, using the UK experience as a policy guide in their own electricity restructuring, privatization, and regulatory reform efforts. In particular, Argentina and Australia have adopted variations of the UK model (as will be discussed in Chapters 3 and 4).

Electricity privatization in the United Kingdom has occurred in the larger context of the privatization of much of the formerly state-owned UK industries and the diminution of the central government's role in the national economy. The overall privatization of industry was initiated shortly after a conservative government came to power in the United Kingdom in 1979 under the leadership of Margaret Thatcher. A primary aim of the new administration was to reduce government's role in the economy. This goal has clearly been achieved. The share of employment accounted for by state-owned industries fell from 7 percent of total UK employment prior to privatization to less than 2 percent currently. ${ }^{1}$

Partly due to the fact that the electricity industry strongly reflects the features of a natural monopoly, electricity was among the last and more controversial privatizations. British Aerospace was the first large industry to be auctioned off in 1981, followed by Cables and Wireless (1981), and by British Telecommunications (1984). Soon afterwards, British Gas (1986), British Airways (1987), British Steel (1988), and British water utilities (1989) were privatized. More recently, British Coal was privatized in 1995, and British Rail in 1996. As of 1995, the United Kingdom has raised over $\$ 95$ billion through privatization. ${ }^{2}$

Electricity privatization and reform got off to a relatively late start in the United Kingdom, having its origins in the passage of the UK's Electricity Act of 1989. The industry was initially restructured by the government along functional lines. Guiding the government's restructuring was the idea that electricity generation and marketing ${ }^{3}$ could be made competitive industries, while transmission and distribution needed to be treated as natural monopolies for the indefinite future. ${ }^{4}$ Regulation would therefore gradually be withdrawn for the former segments but remain for the latter. For the still regulated segments, a new form of regulation (based on a price cap) was introduced-along with a new regulatory authority, the Office of Energy Regulation (OFFER). On Vesting Day (April 1, 1990) a newly-created electricity industry emerged.

The creation of a national wholesale electricity pool was another important area where the United Kingdom charted new ground in electricity reform. As in the United States, a major complication surrounding electricity reform in the United Kingdom was how to allocate the financial burdens associated with stranded costs. (For a discussion on stranded costs associated with electricity in the United Kingdom, see the box entitled "Nuclear Power and the Issue of Stranded Costs.") Stranded costs in the United Kingdom resulted largely from earlier investments in nuclear power and an overhang of high-priced coal contracts.

Although UK electricity reforms are not yet a decade old, some general assessments can be made regarding their performance. In terms of efficiency, the reform of the electric industry in the United Kingdom is generally viewed as a success. By any measure, the current industry is markedly more efficient than it was prior to privatization. However, where issues of fairness and equity are concerned, the industry reforms have been controversial. The new system has been criticized for unfairly and disproportionately benefiting industry shareholders and corporate executives over taxpayers, rate payers, and electricity industry employees. The auction of electricity assets to the general public was criticized for failing to obtain the full value of the assets offered for the treasury. Further, a large share of the industry's efficiency gains was realized through massive workforce reductions. The fact that the heads of the newly-privatized companies were awarded substantial pay raises in the midst of these workforce reductions added to the controversy. ${ }^{5}$ Although electricity prices have generally trailed inflation in the intervening years since electricity reforms were 


\section{Nuclear Power and the Issue of Stranded Costs}

The United Kingdom was one of the first countries to employ nuclear power in electricity generation. The first nuclear power plant, the Calder Hall unit, was connected to the national electricity grid in 1956. In 1995, nuclear power accounted for 26 percent of all electricity generated in the United Kingdom.

As in the United States, most of the UK electric utility industry's stranded costs stem from past investments in nuclear energy. This is largely due to large cost overruns in the construction of nuclear facilities and to unforeseen spent-fuel reprocessing and disposal liabilities, as well as decommissioning costs. "Unlike the United States, however, British nuclear power-up to the time of privatization-had always been publicly owned. Hence, the issue in the United Kingdom of who should bear the burden of stranded costs was between rate payers or tax payers. In contrast, in the United States, the issue of allocating the burden of nuclear energy stranded costs is between rate payers and share holders. Stranded costs are frequently defined as the value of unamortized investments in electricity assets that could not be recovered in a competitive marketplace, or the difference between the market value and the book value of these assets.

In part, the UK public underwrote a share of the nuclear industry's stranded costs the moment it became apparent that the market value of nuclear assets was far less than their book value. The original UK privatization plan intended to couple nuclear power plants with the thermal power assets of National Power (which was later to become a privately-owned generation company in the United Kingdom), and then to auction off the company to the public. However, as nuclear power's high cost structure, spent-fuel reprocessing and disposal liabilities, and decommissioning costs became more apparent, the financial viability of nuclear plants became questionable. Plants build three additional nuclear power plants also raised concerns over the future liabilities of the nuclear power industry. In November of 1989, the UK government announced that the auction of nuclear power assets would be put on hold, and all new construction of nuclear power plants was canceled. In order to sustain the industry until it could be eventually privatized, the government specified quantities of nuclear electricity that each of the regional electricity distribution companies were required to purchase. In 1990, a non-fossil fuel levy of 10 percent of total electricity revenue was put in place. This levy, used to reimburse the regional electricity distribution companies for their purchases of nuclear electricity at above market rates, was to last until 1998. Ninety-one percent of the levy was allotted to nuclear and 9 percent to renewables (such as wind power and biomass). The levy in essence placed a portion of the nuclear industry's stranded costs onto electricity consumers. The permanency of this subsidy, however, was in doubt a factor that continued to jeopardize the nuclear power industry's viability with investors.

Subsequently, the British government decided that only the country's most advanced nuclear power reactors could be privatized successfully. These included five advanced gas-cooled reactors in England, two advanced gas-cooled reactors in Scotland, and one pressurized water reactor in England. Older reactors, using what is known as Magnox technology, were to be retained by the UK government as a public corporation and operated by British Nuclear Fuel, a state-owned nuclear fuel cycle and waste disposal company. When nuclear power was finally auctioned in July 1996 (creating the company British Energy), the \$2.2 billion raised during the auction equaled only the approximate cost of just one of the company's most recently completed nuclear power plants. The remaining costs - the stranded costs-stayed with the government. When British Energy was privatized, its share of the nonfossil fuel levy payment was also terminated. As a result, the overall levy assessment on electricity consumers was dropped from 10 percent to 3.7 percent.

In 1995, British Energy accounted for 18 percent of the UK's electricity supply (British Nuclear Fuel accounted for the remaining 8 percent of electricity supplied by nuclear power). ${ }^{2}$ Unlike other electricity privatization underwriting, there was no windfall to investors in the sell off of British Energy. In the first day of trading, British Energy share prices fell 10 percent. $^{3}$

${ }^{1}$ Other stranded costs include the long-term coal contracts entered into by UK electric utilities. These are discussed in the box entitled: "The Demise of the UK Coal Industry and the Dash to Gas."

${ }^{2}$ UK Electricity Association, Electricity Industry Review (January 1997), p. 33.

"Investors Burn Fingers in Nuclear Sell-off," The Guardian (July 16, 1997), p. 3.

implemented in 1990, electricity consumers have often felt less well treated than industry shareholders, who have realized profits well beyond those reported for UK industry in general over the same period of time.
Privatization of electricity in the United Kingdom did not occur all at once. It evolved. The following sections describe important developments and trends in the UK electricity industry-from its fruition in the last century, 
through the period of nationalization, and up to the current period of industry restructuring, regulatory reform, and privatization. The problems encountered during the period of nationalization are discussed first, followed by a discussion of what has transpired since recent reforms were undertaken.

\section{The Structure of UK Electricity Prior to Privatization}

The central government's role in electricity has grown gradually since the industry's beginning in the latter part of the nineteenth century. The Electricity Lighting Act (1882) allowed the central government to break up streets for laying of electrical cable. The national government established an Electricity Generation Board in 1926 whose mission was to construct a national transmission grid, to coordinate the transmission of electricity across the country, and to establish a set of common technological standards. ${ }^{6}$

In 1947, the electricity industry-along with several other "key" industries - was nationalized by the UK's post-war labor government. All segments of the industry became government owned and operated. So the newlynationalized electricity company comprised most of the country's generation capacity, the national grid, as well as the 12 semi-autonomous regional distribution boards in England and Wales, two vertically-integrated companies in Scotland, and one vertically-integrated company in Northern Ireland.

The role of central government in electricity was extended further with the Electricity Act of 1957. This act established a Central Electricity Generating Board (CEGB) whose responsibilities included control over the operation of electricity generation and transmission facilities and all related investment decisions. The twelve regional electricity boards remained semi-autonomous. An Electricity Council acted as a form of regulator. The council consisted of three representatives of the CEGB, the twelve regional Area Board Chairmen, and six independent members, appointed by the presiding governing Minister. ${ }^{7}$ The regulatory method used employed an inexact and controversial measure of long-run marginal cost in order to construct a bulk supply tariff, the price charged to the distribution companies by the CEGB.

Between 1947 and 1990 - the period of nationalizationthe two major competing national ruling political parties pursued various and often conflicting energy policies. Often electricity policy directives were guided by some overriding macroeconomic objective. ${ }^{8}$ For example, during the 1970's, the ruling labor party put pressure on the electricity industry to restrain prices in order to reduce general inflation. During the 1980's, after the conservative party took power, the industry was urged to increase prices in order to reduce public borrowings. Several currency crises and two oil price shocks encouraged the electric industry to rely more heavily on domestic coal (and not imported crude oil) and to further the development of nuclear power.

A major UK government policy goal for roughly forty years has been the sustenance of the national coal industry-which by the early 1990's had grown vastly inefficient by world standards. Beginning in 1957, in an attempt to support the coal industry, utilities were continually pressured to purchase set quantities of British coal. Eventually, a more formalized arrangement emerged whereby utilities were required to purchase set amounts from the nationalized coal industry at predetermined prices. Since electric utilities were required to pay above world prices for British-produced coal, electricity prices became excessively high, and the British coal industry in essence became dependent on the electricity industry for its survival.

Another major policy goal of the UK government since the 1950 's was the promotion of nuclear power as a secure and economical source of electricity. Nuclear power has also generally been a target of large government-imposed subsidies, again underwritten by the electric utility industry. As elsewhere in the world, when the United Kingdom embarked upon its nuclear power program, nuclear power was perceived as an economically viable form of energy and as a means of achieving energy security. In reality, nuclear power's full costs have far exceeded the costs of non-nuclear forms of electricity generation.

In the 1960's and 1970's, several attempts by the government at reforming the electricity industry were made. However, due to both a lack of commitment and to political turnover, these efforts largely proved unsuccessful. By the 1970's, the United Kingdom experienced several economic setbacks, many of which were attributed to an excessive state role in the economy. A growing disappointment with the general quality of services provided by nationalized companies, along with the nationalized companies' growing financial difficulties, greatly diminished UK public perception of the viability of several state-run industries. At the time, many stateowned companies approached financial insolvency involving several costly government bailouts.

The election of the Thatcher government in 1979 marked a major watershed in British politics and economic policy. 
Privatization became an important element in the Thatcher government's overall economic program. Privatization of nationalized industries was intended to achieve several goals. Foremost among them were to reduce the central government's role in economic decision making; to force privatized companies to become more accountable to owners; to increase net state revenue through asset sales and divestiture of fiscally draining state enterprises; and to encourage the creation of a shareholder society through widespread stock ownership.

\section{The Electricity Act of 1983}

One of the first acts of electricity reform by the Thatcher government was passage of the Electricity Act of 1983. Similar to the Public Utility Regulatory Policy Act (1978) and the Energy Policy Act (1992) passed in the United States, the Electricity Act of 1983 was designed to encourage the growth of independent power producers. It was meant to remove barriers to entry to non-utility generators and to provide independent producers of electricity open access to the national grid. Prior to the 1983 act, entry to the industry was prohibited. The Act required the Central Electricity Generation Board to purchase electricity from private producers at avoided costs, that is, at a price equal to the costs the board would have incurred to produce the same quantity of electricity itself.

The Electricity Act of 1983 was a relatively minor first step toward privatizing and deregulating electricity in the United Kingdom. The establishment of a sizable independent power sector did not occur until several years later. Initially, the low rates of return that the CEGB allowed incumbent power producers discouraged entry of new producers. ${ }^{9}$ Further, the 1983 Electricity Act did not entirely remove the unfair access to the grid that incumbent power producers had over new entrants. ${ }^{10}$ The evolution of a UK independent power production industry-along with the complete transformation of the UK electricity industry as a whole-would await passage of an omnibus piece of electricity legislation which followed six years later.

\section{The Electricity Act of 1989}

Restructuring. In July of 1989, the UK Electricity Act of 1989 was signed into law. One of the most important elements of privatization involved the restructuring of the industry prior to its sale. Initially, the former Central Electricity Generating Board was restructured into four separate organizations: two power producers, a transmission company, and a distribution network consisting of the twelve regional electricity companies (RECs) created out of the twelve former regional area boards. ${ }^{11}$ All segments were to initially remain under government ownership, and privatization was to proceed in stages. The current structure of the UK electricity industry resulted from this process and is depicted in Figure 5. ${ }^{12}$

The Central Generating Board's non-nuclear power units were assigned to two companies, National Power and PowerGen, both slated to be privatized. National Power

\section{Figure 5. Structure of the UK Electric Power Industry}

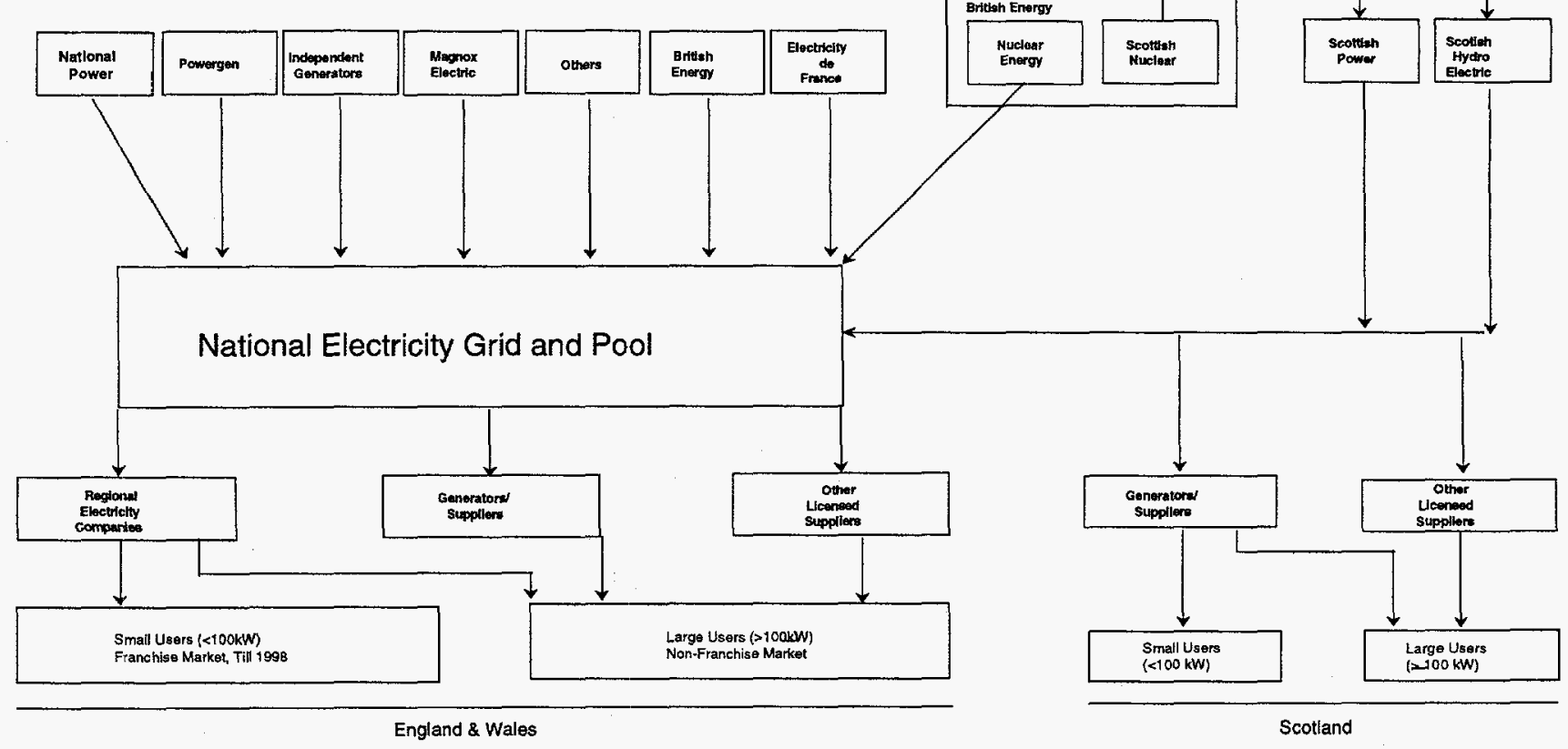

Source: Department of Trade and Industry, Digest of United Kingdom Energy Statistics, 1996. 
was the larger of the two generation companies and accounted for 46 percent of electricity supplied in England and Wales in the 1990/1991 fiscal year time period (Table 2). ${ }^{13}$ At the time, PowerGen accounted for 28 percent of generation output. ${ }^{14}$

Table 2. Share of UK Electricity Generation for Fiscal Years 1990-2001 (Percent)

\begin{tabular}{l|c|c|c}
\hline Company(s) & 1990/1991 & 1995/1996 & 2000/2001 \\
\hline National & & & \\
Power .... & 46 & 31 & 21 \\
PowerGen . & 28 & 23 & 17 \\
Nuclear & & & \\
Electric ... & 17 & 22 & 24 \\
Independents & 1 & 14 & 21 \\
Others .... & 8 & 10 & 17 \\
\hline
\end{tabular}

Note: The data for 1990/1991, 1995/1996, and 2000/2001 correspond to the United Kingdom's fiscal year, which ends on March 31 of each year.

Source: Electricity Industry Review, Electricity Association, London, England (January 1997).

Ownership of the national grid was initially transferred to the RECs upon their privatization. However, in December 1995, the RECs were required by the UK government to divest their shares in the national grid, at which time it became a separate publicly-traded company, the National Grid Company.

The twelve regional electricity distribution companies initially created out of the former Regional Area Boards underwent more changes. In regulatory matters there was to be a separation between the wires (distribution) side of the RECs' business (which was to be continually regulated) and the marketing function of the RECs (which was to be gradually deregulated). The RECs were also the first segment auctioned off to the public by the UK government. These were sold in December of 1990.

Shares in the two power generation companies (National Power and PowerGen) were sold to the public soon afterward, in March of 1991.

Northern Ireland and Scotland's electricity industries were restructured at about the same time as the industries in England and Wales. However, Northern Ireland and Scotland, taken together, account for only about 12 percent of the UK electricity market. (For a discussion on the Scottish and Northern Ireland electricity restructuring, see the box entitled: "The Electricity Industries in Scotland and Northern Ireland.")

In general, references to the UK electricity model in this report address recent electricity developments in England and Wales. A segmental description of reform and privatization of UK electricity follows.

Generation. In the United Kingdom, generation was deemed an area where regulation was needed least of all and where a competitive market could develop most successfully. The only formal restrictions placed on the newly-created private sector power companies was that National Power and PowerGen sell their electricity to a national wholesale pool. (For a discussion on the workings of the power pool, see the section entitled: "The England and Wales Power Pool.")

\section{The Electricity Industries in Scotland and Northern Ireland}

Electric industry reform was much more modest in Scotland and Northern Ireland than in England and Wales.

In Scotland there are three main electricity companies: Scottish Power, Hydro Electric, and Scottish Nuclear. Scottish Power and Hydro Electric are integrated companies supplying generation, transmission, distribution, and marketing services. Scottish Nuclear is the Scottish subsidiary of British Energy. Although Scottish Power and Hydro Electric are vertically integrated, the privatized companies are required to operate each of their different segments independently with no cross subsidization.

A representative of OFFER-the British Office of Electricity Regulation-serves as regulator to the Scottish Electric system and a productivity/performance-based price cap is applied to all segments of the industry.

Northem Ireland operates its newly-privatized electricity industry in a manner similar to the manner in which Scotland operates its electricity industry. Prior to privatization, the vertically-integrated national utility company, Northern Ireland Electricity, provided generation, transmission, and distribution services. During the privatization of Northern Ireland Electricity, the company's four generation units were separately sold off to private energy companies and to employees. The remaining transmission and distribution portion of Northern Ireland Electricity was sold to shareholders intact in 1993. The regulator in Northern Ireland (OFREG) is similar to OFFER. The OFREG regulates generation by using a merit order dispatch operation, where system marginal price becomes the price of the most expensive unit needed to be brought on line in order to meet demand. At the present, the creation of an electricity pool is being considered. 
No specific price regulation was initially intended for generation, as the pool was intended to produce marketbased pricing. However, although OFFER's mandate was not to set pool prices, it had considerable influence over National Power and PowerGen through its authority to refer cases involving monopolistic behavior to the Monopoly and Mergers Commission (MMC). Concerns over whether the generation business was sufficiently competitive and was behaving as a duopoly caused OFFER to intervene several times after privatization. ${ }^{15}$

In December 1993, a sharp increase in electricity pool prices prompted OFFER to reduce market concentration in electricity supply by negotiating an agreement with National Power and PowerGen whereby the two companies would use their best efforts to sell off 6000 megawatts of generating capacity-roughly 15 percent of the companies' combined capacity and 9 percent of total UK electricity generation capacity. This objective was met by both companies during the following year. Further, in February of 1994, OFFER proposed a cap on pool prices which was implemented for the 1994/1996 fiscal year time period, again due to concerns that the two generators exercised undue influence in electricity supply.

In late 1995, due to an eruption of mergers and acquisitions (discussed later in this chapter), the government intervened again to prevent integration in the electricity industry. The government's primary concern was the growing vertical industry concentration between domestic generation and distribution companies. The two power generation companies had each mounted takeover attempts of two regional electric utilities.

In the fall of 1995, National Power placed a bid for Southern Electric (a REC), and PowerGen placed a bid for Midlands Electricity (another REC). The Minister of Trade, however, announced that both deals would be referred to the MMC. When the MMC later approved the two deals, the Minister of Trade decided to block them anyway, announcing that, although he didn't find vertical integrations "inherently objectionable," he was concerned that "structural change could have an effect on the development of competition in the industry." ${ }^{\prime 16}$ At the time, the Minister of Trade had the backing of OFFER. ${ }^{17}$ The Minister of Trade further stated that vertical integration between generators and distributors might pose "significant detriments to competitions."18 The disapproval of the National Power and PowerGen takeover bids had the effect of aborting another potential takeover, this time of National Power by Southern Company, a U.S. electric utility.

Two other acquisitions (both involving a REC and a power company) went undeterred by the regulators. One of these involved Scottish Power's 1995 acquisition of
Manweb. Apparently, due to Scottish Power's geographical location, its acquisition of Manweb posed less of a threat to competition than the takeover attempts occurring in England proper. The other acquisition involved Hanson's purchase of generation assets from National Power and PowerGen, shortly following Hanson's purchase of another REC, the Eastern Group. ${ }^{19}$

An important means of leverage the government retained over the electricity industry after privatization was exercised through its "golden share" in the two power generation companies and the twelve RECs. Since Vesting Day (April 1, 1990), the government had restricted any single private entity's ownership in the two generation companies and the twelve RECs to a maximum stake of 15 percent. For the RECs, the government's "golden share" expired in March of 1995. The government's "golden share" in the generation companies was extended in March of 1991, and in May of 1996 the government indicated that it would retain its "golden share" in the two power generation companies indefinitely.

Transmission. In contrast to generation, the UK's transmission system was considered a natural monopoly (as was distribution, which is discussed below). With the breakup of the CEGB, all transmission assets fell under the ownership of the National Grid Company (NGC). The twelve RECs assumed ownership of the NGC, although safeguards were put in place to restrict the RECs' influence over managing the grid. In addition to providing electricity transportation services throughout England and Wales, the NGC also supported the mechanism from which electricity supply and demand were balanced: the England and Wales Electricity Pool ("the pool").

The pool requires that electric power generators whose capacity exceeds 100 megawatts are required to submit their generation units to dispatch by the NGC. The UK adopted a form of price cap regulation for transmission services known as RPI- $X$. RPI- $X$ essentially imposed periodic price reviews and price caps based on changes in the overall rate of inflation (as measured by the retail price index (RPI)) less expected future productivity gains (the $X$ ). (For a review of RPI-X regulatory rate reform, see the section entitled: "RPI-X: Price Caps versus Rate of Return Regulation.") Initially, the NGC owned some generation capacity. However, in 1995, the regulator required the NGC to sell off its two hydroelectric pumped storage generation assets over concerns that vertical integration in generation and transmission hindered competition. The NGC sold its generation assets to Mission Energy (a subsidiary of Edison International, which also owns Southern California Edison) in January of 1996. Further competition-related concerns encouraged the regulator to require the RECs to sell off their shares in 
the NGC in December of 1995, thus making the NGC a separate company under the new name, National Energy Group PLC.

Distribution. Since privatization, electricity distribution in England and Wales has been managed by the twelve RECs (Table 3). The wires (distribution) side of the RECs' business was to be regulated indefinitely. The marketing side of the industry was to be deregulated gradually.

\section{Table 3. Regional Electricity Distribution Companies in the United Kingdom Ranked by Electricity Distributed, Fiscal Year 1994/1995}

\begin{tabular}{|c|c|}
\hline Company & $\begin{array}{l}\text { Electricity Distributed } \\
\text { (GWh) }\end{array}$ \\
\hline Eastern Group . . . . . . . . . & 29,898 \\
\hline Southern Electric ........ & 26,808 \\
\hline Midlands Electricity . . . . . . & 24,709 \\
\hline East Midlands Electricity . . . & 24,156 \\
\hline Yorkshire Electricity . . . . . . & 22,631 \\
\hline NORWEB . . . . . . . . . . & 22,076 \\
\hline London Electricity . . . . . . . & 19,666 \\
\hline Manweb ............... & 18,485 \\
\hline SEEBOARD $\ldots \ldots \ldots \ldots$ & 17,655 \\
\hline Northern Electric . . . . . . & 14,950 \\
\hline SWEB . . . . . . & 12,979 \\
\hline SWALEC $\ldots \ldots \ldots \ldots$ & 11,164 \\
\hline
\end{tabular}

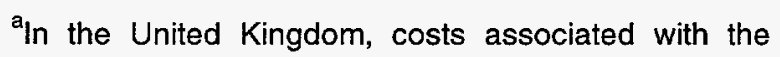
privatized, deregulated electricity industry are often expressed in budgetary time periods (i.e., April 1 to April 1 fiscal years) and not calender year time periods. Thus, 1994/1995 is April 1, 1994 to April 1, 1995.

Source: Department of Trade and Industry, Digest of United Kingdom Energy Statistics (1996) p. 98.

The distribution side of the RECs' business was also to be regulated through an RPI-X form of price regulation. The franchised ${ }^{20}$ marketing portions of the RECs' business segments were to be regulated in a similar fashion, albeit with a different productivity factor (" $X$ ") and a different regulatory time frame. On Vesting Day, the government provided the RECs with price caps ranging from a high of zero to a negative " $X$ " of 2.5 percent. Negative " $X$ " (that is, an apparent allowance for annual rates of productivity decreases of $X$ percent) factors were chosen in order to provide the industry with sufficient future cash flow in part to meet projected future investment needs and also to increase the attractiveness of the companies to the investment community during their upcoming public auction. The initial regulatory timeframe was set at the fiscal year 1990/1995 time period.
Since privatization, the distribution companies have been allowed to acquire generation assets with the restriction that no REC generation facilities account for more than 15 percent of their individual electricity sales. This action was taken in order to introduce more competition in generation. Allowing individual RECs to produce their own electric power led to a surge in REC investment in independent power producers, whose preferred method of generation was the combined cycle natural gas turbine. (For a discussion on natural gas and electric power developments in the United Kingdom, see the section "Natural Gas Privatization in the United Kingdom.") The RECs are, however, required to separate, in an accounting way (or by a "ring fence" as it is termed in the United Kingdom), their marketing business from their distribution business.

Marketing. As stated earlier, the marketing segment of the electricity industry along with generation was considered to be potentially competitive. However, marketing (unlike generation where market-based prices are set in the electricity pool) is being gradually deregulated. On Vesting Day, large users of electricity (the newlycreated non-franchised market) were allowed to choose their marketers, as opposed to being required to purchase electricity from their REC. This group-the large users - consisted largely of a relatively small number of industrial companies (Table 4). ${ }^{21}$ The RECs were allowed to retain their franchise in the mid-user market (the small industrial and commercial companies) until April 1994. ${ }^{22}$ The RECs must compete for the remaining franchised consumers (primarily residential users) ${ }^{23}$ in April of 1998.

The Electricity Act of 1989 thus encouraged competition in marketing by opening the large-user portion of this end of the electricity business to new entrants. While the RECs still had captive rights to all other consumers, large users were free to purchase electricity services from their local RECs' newly created marketing segment, or from a second tier marketing company, i.e., a newly-created marketing company unaffiliated with their local REC. As of 1996, 39 second-tier suppliers have entered the market. These second-tier suppliers include several RECs operating outside of their franchised distribution territories, as well as the newly-created electricity marketing units of the two privatized generation companies, National Power and PowerGen. Due to concerns relating to maintaining competition, however, the generators (as well as the RECs) were required to establish separate marketing units.

It appears that deregulation has given rise to greater competition in the marketing end of the electricity market. In the aftermath of the opening up of the industrial market to competition, the newly-formed second tier suppliers have made substantial inroads into what had been a captive market for the RECs. Since Vesting, the 
Table 4. The Incremental Deregulation of the End-User Electricity Market

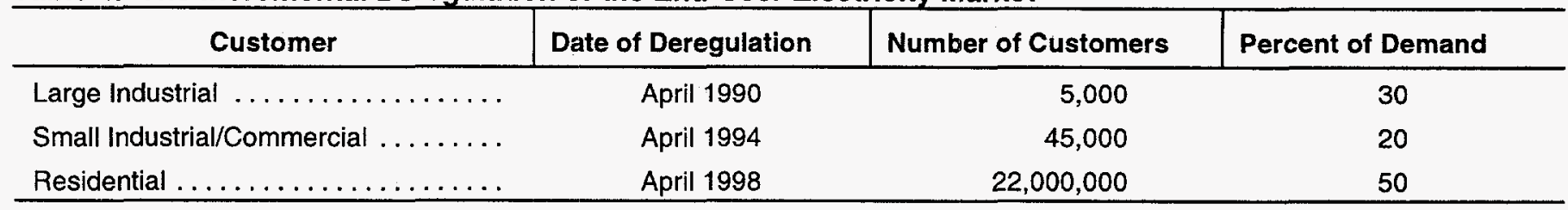

Source: Steve Thomas, "The Development of Competition," The British Electricity Privatization Experiment, Privatization: The Record, the Issues, the Lessons, ed. John Surrey (London, England: Earthscan Publications Limited, 1996), p. 69.

second-tier companies have seen their share of the large industrial market climb from 43 percent in the 1990/1991 period to 69 percent in the $1995 / 1996$ period (Table 5). This occurred despite the fact that marketing costs for the large industrial customers are very small relative to the costs of generation (Table 6). Newly-formed marketing companies have also made substantial gains in the 100 kilowatts to 1 megawatt market. In the mid-range commercial and small industrial company market, the secondtier companies' share has risen from 30 percent in the $1994 / 1995$ fiscal year time period to 43 percent in the 1995/1996 fiscal year time period.

Another area of continued regulation of the retail electricity business in the United Kingdom concerned services standards. Although services provided by the electric industry in the United Kingdom were generally considered reliable even prior to reform, higher quality of service standards were placed on the industry by OFFER during the initial privatization phase. These standards were later tightened in 1993 and 1994. RECs are required to offer various special services to the elderly and disabled. Service standards also were directed to bill payment, meter reading, and speedy responses to complaints.

It is not clear whether the second-tier marketing companies will be as successful at encroaching on the RECs' share of the residential market as they were in the largeto-mid-level user market. Even though marketing costs to residential users (unlike industrial and commercial users) account for a relatively large portion of their overall electricity bill, the residential market is expected to be a more difficult market to break into. This is largely due to the high estimated costs (such as in advertising) which would need to be incurred to encourage small consumers

Table 5. Non-Franchise Market Shares in England and Wales

\begin{tabular}{l|c|c|c|c|c}
\hline \multicolumn{7}{c}{ Large Industrial } & \multicolumn{2}{c}{ Small Industrial/Commercial } \\
\hline Electricity Supplier & $1990 / 1991$ & $1994 / 1995$ & $1995 / 1996$ & $1994 / 1995$ & $1995 / 1996$ \\
\hline RECs ( First Tier) ..... & 57 & 37 & 31 & 70 & 57 \\
Second Tier ........ & 43 & 63 & 69 & 30 & 43 \\
Total ............ & 100 & 100 & 100 & 100 & $100^{\prime}$ \\
\hline
\end{tabular}

Note: The data correspond to the United Kingdom's fiscal year, which ends on March 31.

Source: Electricity industry Review, Electricity Association, (London, England, January 1997).

Table 6. Share of Component of Electricity Costs for Different Classes of End Users

\begin{tabular}{|c|c|c|c|c|c|}
\hline Customer Profile & $\begin{array}{c}\text { Generation } \\
\text { Costs }\end{array}$ & $\begin{array}{c}\text { Transmission } \\
\text { Costs }\end{array}$ & $\begin{array}{l}\text { Distribution } \\
\text { Costs }\end{array}$ & $\begin{array}{l}\text { Marketing } \\
\text { Costs }\end{array}$ & Total \\
\hline Large Industrial & 77 & 5 & 17 & 1 & 100 \\
\hline $\begin{array}{l}\text { Small } \\
\text { Industrial/Commercial . . . . }\end{array}$ & 66 & 6 & 24 & 4 & 100 \\
\hline Residential . . . . . . . & 58 & 5 & 29 & 8 & 100 \\
\hline
\end{tabular}

Source: Mike Parker, "Competition: the Continuing Issues, "The British Electricity Privatization Experiment, Privatization: The Record, the Issues, the Lessons, ed. John Surrey (London, England: Earthscan Publications Limited, 1996 ), p. 217. 
to switch suppliers. With unbundled electricity rates, different classes of consumers face different price schedules. For instance, industrial users have a tendency to face a cost structure where the share of generation costs relative to total costs far exceed that of smaller users. In contrast, residential and mid-level users face disproportionately higher distribution and marketing costs. The transmission cost portion of final electricity bills tend to be uniform across all classes of consumers.

\section{The England and Wales Power Pool}

In order to balance electricity supply and demand, the UK government instituted a power pool to act as a clearinghouse between suppliers of electricity (generators) and wholesale consumers of electricity (primarily the regional electricity distribution companies). The pool is open to all generators and consumers wishing to participate.

Those electric power generators whose capacity exceeds 100 megawatts are required to submit their generation units to dispatch by the National Grid Company (NGC). The NGC manages and operates the pool with an independent facility that attempts to balance supply and demand with an auction which roughly operates in the following manner. In the power pool every day is broken up into forty-eight half-hour segments. The system manager forecasts demand for each half-hour segment. Twenty-four hours in advance, generators submit bids for the various levels of power they are willing to supply at various prices and for various periods, for each half-hour period of the following day. The system manager then ranks these bids from least to most expensive. The system manager also calculates the minimum amount of generating capacity needed to meet demand projections. A merit order dispatch schedule is created whereby the cheapest generation units are selected first and supply is capped when enough generation units are selected into the system to cause generation capacity to be sufficient to supply one unit of energy over and above the forecasted demand. ${ }^{24}$ The pool purchase price for all suppliers becomes the highest price bid by the last generation facility needed to accommodate the last unit of demand. This balancing activity is an attempt to arrive at the electricity generation industry's marginal cost, or the system marginal price (SMP).

The price actually paid to generators also includes a financial incentive for maintaining some additional (peak load) generation capacity in the event that demand exceeds consumption forecasts. This capacity payment equals the value of lost load (VOLL) times the loss of load probability (LOLP). The VOLL attempts to measure the system cost of not producing enough electricity to meet peak load. Another way of looking at VOLL is that it attempts to measure the "extent to which generators are prepared to invest in additional capacity in excess of the actual maximum on the system. ${ }^{\prime 25}$ The LOLP simply measures the probability that supply will be insufficient to meet demand at a particular point in time.

The LOLP changes over the course of the year and the course of the day. The closer demand is to scheduled supply, the higher the LOLP and therefore the higher the capacity payment. The price paid to electricity suppliers is the pool input price (PIP), which equals SMP + (VOLL ${ }^{*}$ LOLP). The price paid by purchasers is the pool output price (POP), which equals the PIP plus an uplift charge, calculated to cover certain ancillary functions, such as reserve plant availability, forecasting errors, transmission constraints, and marginal plant adjustments. ${ }^{26}$

In practice, electricity prices in the England and Wales electricity pool have proven to be very volatile and subject to possible manipulation. Over time there have been several allegations that, due to their dominant position in the pool, National Power and PowerGen have been able to manipulate pool prices. ${ }^{27,28}$ According to these allegations, ownership of some relatively high-cost marginal plants have enabled the two dominant utilities to attempt to ensure that these units are offered up to the pool in such a way that they determine the SMP. The fact that both companies were once the same company suggests that each possesses an intimate understanding of the other's cost structure.

Thus, as a means of controlling price volatility, a hedging market has developed. This market (called the contract for differences market [CfD]) allows for bilateral contracts to be negotiated between generators and consumers. ${ }^{29}$

The CfD evolved from contractual relations imposed on the industry by the UK government at Vesting Day (April 1, 1990). At the time, the two recently-privatized UK generation companies (National Power and PowerGen) were encumbered with contracts to purchase high-price British coal. In order to prevent other electricity generation companies (such as the recently-created independent power-producing companies) from capitalizing on this disadvantage, the regional electricity companies were required to purchase power from the two primary generation companies.

In the CfD market, generators and electricity purchasers can hedge pool prices by committing to a contract with an agreed-upon price, (the strike price). The strike price, for instance, may be set at an average of expected daily pool prices. If the strike price turns out to be higher than the daily average pool price, then the generator pays the purchaser the difference. Conversely, if the strike price turns out lower than the daily average pool price, the 
electricity purchaser reimburses the generator for the difference. In reality the CfD market uses a variety of different hedging contracts. Contracts for differences are purely financial contracts; however, in terms of hedging pool prices, they cover more than 90 percent of the electricity traded in the pool. ${ }^{30}$ Nonetheless, pool prices have still continued to be a source of controversy.

In February of 1994, in response to a sharp run up in pool prices in April of 1993, OFFER issued its first report on pool pricing activity. The report called for a two-year price cap and required National Power and PowerGen to sell off 6000 megawatts of generation capacity. Since February of 1994, OFFER has issued five reports on pool pricing. ${ }^{31}$

\section{RPI-X: Price Caps Versus Rate-of-Return Regulation}

Price-cap regulation is generally viewed as a relatively recent form of regulation, and is most frequently associated with the ongoing regulatory reform and privatization in the United Kingdom. In contrast, rate-of-return regulation is the most commonly used form of utility regulation in the United States, and has been in use for decades. Both forms of regulation, however, attempt to accomplish the same goal: to reduce the power of natural monopolies $^{32}$ to restrain output, raise prices, and realize supra normal profits. In theory, the way the two regulatory methods accomplishes these goals differs considerably. In practice, however, the methods have tended to converge.

Rate-of-return regulation is also called cost-of-service regulation in that it essentially allows companies to pass through those costs which are deemed necessary by the supervising regulatory body to ensure that an adequate level of service is provided to end users. During periodic regulatory reviews, expenditures that are deemed appropriate by the regulatory body are added to the rate base. In order that appropriate levels of capital investment are undertaken, supervising regulatory bodies (in the United States, these are generally State public utility commissions) estimate appropriate rates of return for the regulated utility, based in part on the cost of capital to the utility.

Rate-of-return regulation has both its virtues and its weaknesses. Rate-of-return regulation allows representation of the public in matters regarding utility price setting, rates of return, and investment so that utilities cannot restrain supply and realize monopoly profits. However, rate-of-return regulation offers utilities few financial incentives to aggressively restrain or reduce operating costs. ${ }^{33}$
Price-cap regulation has been the common means of regulation for the recently privatized industries in the United Kingdom. For several reasons, rate-of-return regulation was rejected in the United Kingdom. For one, obtaining detailed industry data was deemed an excessively expensive effort that would require a large bureaucratic structure. Further, it was felt that regulators would always suffer from a disadvantage, given that any information the regulator obtained from the regulated industry was always incomplete relative to the information possessed by the industry, leaving the regulator in an inferior negotiating position relative to that of the industry. Moreover, as stated earlier, rate-of-return regulation offered insufficient incentives for the utilities themselves to reduce costs aggressively.

To avoid these problems, the United Kingdom adopted what was felt to be a hands off, less-bureaucratic, regulatory method based upon price caps and periodic reviews. This new form of regulation often goes by the name of RPI-X. RPI-X regulation is also often called "performance-based regulation" in that it seeks to achieve economic efficiency through altering the incentive structure of the industry.

\section{How RPI-X Works in Theory}

In essence, RPI- $X$ employs price caps which allow individual utilities (or companies) discretion over all investment and operating decisions. In contrast to rate-of-return regulation, utilities in the United Kingdom realize all gains from efficiencies achieved beyond the established benchmark up until the next regulatory review. RPI- $X$ regulation has not only been employed in the electricity sector but also has been applied to the recently privatized telecommunications, natural gas, and water industries. For expository purposes, a generalized form of RPI-X pricecap regulation works the following way:

Let us suppose $t$ is our base year and $\mathrm{p}_{\mathrm{t}}$ are electricity prices in the base year. The RPI in RPI- $X$ regulation represents the change in the retail price index in the United Kingdom and is a measurement similar to the Consumer Price Index (CPI) in the United States. $X$ is generally considered to be a productivity factor, which could be positive if the industry is expected to operate more efficiently in the future, or negative if efficiency declines are expected. ${ }^{34}$ The productivity factor, $X$, is based upon past performance and projected analysis of future productivity gains. ${ }^{35}$ A third variable (let's call it $\mathrm{K}$ ) could be added to the equation to account for all costs over which a regulated company had no control (exogenous costs), allowing, for instance, an electricity company to directly pass through all costs related to changes in energy prices (making our new equation, 
assuming efficiency gains, $R P I-X+K)$. Thus, maximum prices one year hence $\left(P_{t+1}\right)$ should equal: $p_{t+1}=p_{t}+R P I-$ $\mathrm{X}+\mathrm{K}$.

RPI-X regulation employs a multi-year review cycle. In the United Kingdom, depending on the industry being regulated, the review cycle has typically been from 3 to 5 years. This allows companies to realize the benefits of their cost reduction efforts over a set period of time, or until the next review cycle comes due. Upon completion of the regulatory cycle, the regulator conducts a new review and redetermines new benchmarks both for the initial set of prices and for projected future productivity gains. The regulator is then able to pass on some of the benefits of the realized efficiency gains to consumers.

In England and Wales, RPI-X regulation has been applied only to those segments of the industry still deemed natural monopolies (or not ready for complete competition). These segments are basically the wires (electricity transmission and distribution) portion of the business (Table 7). RPI-X is not applied to the generation of electricity, a sector in which the price setting mechanism is the national electricity pool. RPI-X is also currently being applied to electricity marketing for residential users (although this market is scheduled for deregulation in 1998). Prices in the other segments of the industry, generation and nonfranchised marketing are in general freely determined in the marketplace.
The chosen base price in the United Kingdom was directly related to the asset value at the beginning of the initial regulatory period. The selected productivity factors tended to vary across segments of the industry, with the transmission companies assigned an initial $X$ of zero. For the twelve distribution companies, various $X^{\prime} s$ were applied, varying from zero to a positive top rate of plus 2.5. The franchised supply companies were assigned an initial $X$ of zero. The regulatory cycles for the three regulated industries have varied from 3 to 5 years.

\section{How RPI-X Worked in Practice in the UK}

RPI-X is supposed to provide utilities with a stronger incentive to reduce costs than rate-of-return regulation because the utilities themselves realize all the value of the cost reductions made beyond the benchmark. ${ }^{36}$ The other supposed advantage of RPI-X regulation is that it is also designed to reduce regulatory costs and provide a disincentive for the regulated to engage in costly activities designed to influence the regulator (an activity called regulatory capture) ${ }^{37}$ The visibility of a single national regulator may also provide for more accessible public scrutiny of regulatory decisions.

However, RPI-X regulation has some clear shortcomings, both theoretical and practical. One problem is calculation of the appropriate initial level of prices. In the United Kingdom, this proved particularly difficult because the

Table 7. The UK's Office of Energy Regulation RPI-X Price Controls, and Review Periods

\begin{tabular}{|c|c|c|c|c|c|}
\hline Activity & $\begin{array}{l}\text { Pricing } \\
\text { Method }\end{array}$ & $\begin{array}{l}\text { Regulatory } \\
\text { Period }\end{array}$ & Price Index & $\begin{array}{c}\text { Segment } \\
\text { Regulated }\end{array}$ & Unregulated \\
\hline Generation & Pool & NA & NA & None & All \\
\hline \multicolumn{6}{|l|}{ Transmission } \\
\hline Initial Control Period & RPI-X & $4 / 90-4 / 93$ & RPI-0 & All & NA \\
\hline Second Control Period & RPI-X & $4 / 93-4 / 97$ & RPI-3 & All & NA \\
\hline Third Control Period....$\ldots \ldots$ & RPI-X & $4 / 97-4 / 01$ & $\mathrm{RPI}-4$ & All & NA \\
\hline \multicolumn{6}{|l|}{ Distribution } \\
\hline Initial Control Period . & RPI-X & $4 / 90-4 / 95$ & Various $\mathrm{RPI}+\mathrm{X}$ & All & NA \\
\hline Interim Control Period & RPI-X & $4 / 95-4 / 96$ & $\begin{array}{l}\text { See Table } 14 . \\
\text { Various RPI-X }\end{array}$ & All & NA \\
\hline Second Control Period & RPI-X & $4 / 95-100$ & RPI-3 & All & \\
\hline \multicolumn{6}{|l|}{ Supply } \\
\hline \multirow[t]{2}{*}{ Initial Control Period } & RPI-X & $4 / 90-4 / 94$ & RPI-0 & $<1 \mathrm{MW}>100 \mathrm{~kW}$ & $>1 \mathrm{MW}$ \\
\hline & & & & $<100 \mathrm{~kW}$ & \\
\hline \multirow[t]{2}{*}{ Second Control Period...$\ldots \ldots$} & RPI-X & $4 / 94-4 / 98$ & $\mathrm{RPI}-2$ & $<100 \mathrm{~kW}$ & $<1 \mathrm{MW}>100 \mathrm{~kW}$ \\
\hline & & & & & $<100 \mathrm{~kW}$ \\
\hline Third Control Period $\ldots \ldots \ldots \ldots$ & RPI-X & $4 / 98-4 / 02$ & None & None & None \\
\hline
\end{tabular}

NA $=$ Not Available.

Source: Electricity Association, Electricity Industry Review (January 1997). 
government was also attempting to maximize the value of these companies for a successful initial public offering. Lower future electricity prices would have meant lower immediate gains to the treasury during the public auction of electricity industry assets.

A second problem involves estimating future productivity gains. In practice, this has proven to be a rather problematic process in the United Kingdom. In order to achieve the desired allocation of the future benefits achieved through realizing greater industry efficiency gains, the regulator would still need detailed knowledge of the industry and future market developments in order to come up with a suitable initial price and projected future productivity gains. In addition, $X$ would represent not expected future productivity gains, but rather some theoretical cutoff rate for electric utilities to have an incentive to surpass in order to retain all of the cost reductions benefits that accrue beyond $X$.

Thus far, in terms of economic efficiency, RPI-X has been a clear success. In the United Kingdom, the RPI-X regulatory approach has induced cost reductions well beyond expectations. Electricity companies have been able to greatly reduce operating costs in large part through substantial work force reductions. As intended, the electricity industry has benefited financially because these cost reductions have made substantial contributions to the bottom line results. However, substantial controversy has surrounded the new form of electricity regulation. In particular, some dissatisfaction has arisen over whether the efficiency gains (the economic rents) have been equitably distributed between the industry's stakeholders, i.e., investors, labor, and consumers. As a result of this controversy, several of the basic tenets of RPI-X pricing have become suspect.

\section{The Sale of UK Electricity}

A controversial element in the privatization process concerns the means by which the transfer of public ownership and control to private ownership and control is carried out. ${ }^{38}$ In the United Kingdom, public flotations were used to transfer ownership of electricity industry assets. These flotations involved several objectives, one of which was to raise money for the treasury and improve the financial position of the national government. Maximizing treasury revenue through competitive sales does much to assure taxpayers that fair value was obtained in the sale of public assets. In general, full market value is realized most quickly in markets that are highly liquid; hence, there was a strong emphasis on market breadth-i.e., opening the auction to the most bidders. As a consequence, foreign investors were allowed to bid for a limited number of shares.
However, in the United Kingdom, the flotation was also conducted to further yet another goal-shareholder democracy. Certain shares were reserved for small UK shareholders in order to induce more widespread ownership of industry among social classes. Restrictions on ownership (especially during the early stages of privatization) were also employed to allow the national government to retain some influence over future corporate governance.

Another government goal during the flotation was to achieve a timely sale since privatization lacked a clear national consensus and a change in government might lead to its reversal. The conservative government was determined to complete the privatization process as soon as possible in order to discourage any future successor labor government from slowing down or reversing the process. The performance of earlier sales of major UK industries also influenced the method of electricity industry sell off. Some earlier company sales, notably British Gas and British Petroleum, had been viewed as less than a success. ${ }^{39}$

An overriding issue in the privatization of electric utilities in the UK concerns the tradeoff between equity and efficiency. Whereas economic efficiency in electric power generation is relatively easy to define in theory, achieving social equity through privatization becomes a somewhat subjective, but clearly not trivial matter, in privatization's perceived success and public support. In the United Kingdom, much political controversy surrounded the initial public auction of the electric distribution companies. Again, this related to whether the treasury obtained fair value for the companies sold.

Privatization got underway in late 1990. The RECs were the first segment of the industry to be sold in December of 1990 with their shares being sold for $\$ 11.6$ billion..$^{40}$ Fiftyfive percent of the shares sold went to individual investors, 30 percent to institutional investors, and 15 percent to foreign investors.

Interestingly, the UK government did not set out on the price discovery path via a direct auction of shares in the restructured electricity industry. Nearly a half-year prior to the flotation of the RECs, the UK government canvased major institutional investors to help determine the value of the assets to be sold. Later, the government conducted an effort to solicit retail customers through a massive advertising campaign costing $\$ 23$ million. Wider share ownership was also a major goal in the sell off of the electricity industry. Favorable payment terms were offered to household investors.

The RECs were finally sold at a fixed price of $\$ 3.40$ per share which was calculated to provide investors with an 
8.4-percent dividend yield. On Vesting Day shares of the RECs soon began trading on the London stock exchange and the values of these shares rose sharply. Although it is common in initial public offerings of privately-owned companies for underwriters to underprice shares somewhat, the value of the RECs' share appreciation far exceeded that of average share appreciation of the initial public offerings of privately-owned companies.

There are several possible reasons why this might have happened. One is that the government and its underwriters simply grossly underestimated the RECs' value. The government could have approached the price discovery process via a staged auction of the RECs' shares. Another is that the government intentionally understated the RECs' value in order to dramatize the success of the initial public offering. (In fact, Labor has accused the government of intentionally underpricing the RECs' value for the benefit of investors over tax payers.) There is also the possibility that the government priced the RECs at a substantial discount to preclude the possibility that any future Labor government would try to renationalize these companies.

The investing public generally viewed the government's calculation of appropriated share price as highly undervalued and commitments to purchase shares exceeded share availability by a factor of ten. The degree to which the sale was oversubscribed had several implications. The first was that the flotation was handily carried out. There were, however, some problems associated with the degree to which the flotation was oversubscribed. Most investors did not obtain as many shares as they had bid for and several investors received none. Further, the large runup in share prices after trading began gave rise to accusations that the government did not obtain fair value in the sale of public assets and that investors left out of the flotation were subsequently deprived from benefiting from the windfall.

Soon after the RECs' sale, the UK government sold shares in the two generation companies. Sixty percent of the two power companies shares were sold in March of 1991. (The government's 40-percent stake was sold in March of 1993). Shares of National Power and PowerGen were packaged together in the sale so that winning bidders received in the minimum 62 shares of National Power and 38 shares of PowerGen per 100-share tranches. ${ }^{41}$ The proportion of shares to be made available to institutional investors was initially set at 52 percent. However, during the sale, a mechanism went into play which reduced the maximum institutional share to 28 percent of the available supply. Investors from the United States were prominent among the foreign participants. An estimated $\$ 1$ billion in shares were sold to U.S. investors. In the end, individual investors' shares of the National Power and PowerGen sales stood at 49 percent, and foreign investors' shares at 23 percent (10 percent of the foreign share went to investors from continental Europe, 6 percent to Japan, 5 percent to the U.S., and 2 percent to Canada).

The UK government conducted the initial public offering of the generation companies, National Power and PowerGen, differently from that of the RECs. First of all, the government set the dividend yield at a rate significantly below the rate on the RECs. Secondly, only a portion of the companies-60 percent-were sold off during the initial public offering. Thirdly, an auction of sorts was held to order to achieve greater price discovery and treasury revenue.

Institutions were required to submit bids for a portion of the shares set aside from the initial sale. Those submitting the higher bids were awarded a priority in the second round of bidding where there were no rules (i.e., a real auction). Sixteen percent of the generator's final tranch of shares was reserved for a tender offer which took place on the first day of trading. Discount prices were offered to small shareholders.

The sale was oversubscribed by a factor of 6 and share prices rose 37 percent during the first day of trading. Although the level to which the generator's initial public offering was oversubscribed was large, due to the lower dividend yield it was roughly half the level to which the RECs were oversubscribed.

The fact that the sale of the generation companies and the RECs was so oversubscribed (and that share prices surged in their first day of trading) suggested to some that these companies were underpriced by the government. While investor enthusiasm was heralded by the conservative government as an indicator of the auction's success, the Labor Party accused the conservative government of not obtaining a fair value in the sale of public assets.

The National Grid Company (NGC) was initially privatized in December of 1990, at the same time as the RECs. The NGC became a separate company in December of 1995. Unlike shares in earlier privatizations, shares in the National Grid Company (NGC) were not sold but were distributed to shareholders in the twelve RECs.

When the NGC was subsequently divested in December of 1995, the UK government paid greater attention to the issue of public equity, giving consumers a 50-pound rebate from the proceeds of the flotation. ${ }^{42}$ The generation units of the NGC were then sold off in January of 1996. Neither National Power or PowerGen were allowed to bid on the generation units. ${ }^{43}$ None of the five newly-created generation subsidiaries of the regional distribution companies were allowed to have more than a 1-percent stake in the newly-privatized NGC. 
Throughout the public flotations of electricity industry assets, the government held onto at least a partial share of each company being privatized. The UK government share was not seen as ownership per se, but rather a restriction on any individual party's ability to obtain more than a 15-percent share in any privatized company. Thus, the government's "golden share" was clearly a deterrent to the occurrence of any radical change in the ownership structure of the electricity industry too soon after privatization. The "golden share" allowed the government to exercise some residual control over corporate governance of the industry. It also restricted the degree to which any other party could obtain corporate control over any company and in essence determined that initial investment in any company would be of a portfolio nature.

As previously discussed, the government's "golden share" of the RECs expired in March of 1995 and was followed by a spree of mergers and acquisitions among generation companies and distribution companies. Due to concerns that a similar development might take place with electricity generation, the Department of Trade and Industry announced in May of 1996 that it would retain its share in National Power and PowerGen indefinitely. ${ }^{44}$

\section{Electricity Investment Activity}

\section{Mergers and Acquisitions and U.S. Investors}

As noted earlier, prior to privatization the UK government restructured the electricity industry; after privatization, the market undertook a restructuring. Foreign investors played an important role in this second round of industry restructuring. Soon after the UK government's "golden share" in the regional electricity companies expired in March 1995, the RECs became a prime takeover target. Eventually, eleven of the twelve RECs were merged with or acquired by other companies. In the fall of 1995, both recently-privatized power generation companies, along with Scottish Power, placed bids on the recentlyprivatized distribution companies. There was also widescale integration and cross investment in electricity, natural gas supply, water supply, and telecommunications. Electric utility companies from the United States were the most aggressive bidders for the RECs.

Since the expiration of the government's "golden share," all of the twelve UK distribution companies and one power company have been takeover targets (Table 8).

Table 8. Recent Merger and Acquisition Activity in UK Electricity (Million Dollars)

\begin{tabular}{|c|c|c|c|}
\hline Regional Electricity Companies & Acquirer/Merger Partner & $\begin{array}{c}\text { Year of } \\
\text { Acquisition }\end{array}$ & $\begin{array}{c}\text { Value } \\
\text { Billion Dollars }\end{array}$ \\
\hline East Midlands Electricity . & Dominion Resources (U.S.) & 1996 & $\$ 2.2$ \\
\hline London Electricity & Entergy (U.S.) & 1996 & $\$ 2.7$ \\
\hline Yorkshire Electricity & American Electric Power \& PS Colorado (U.S.) & 1997 & $\$ 2.4$ \\
\hline Northern Electric & Calenergy (U.S.) & 1996 & $\$ 1.5$ \\
\hline Eastern Group & Hanson (UK) $/$ Pacific Corp. (U.S. $)^{b}$ & $1995 / 1997$ & $\$ 9.6$ \\
\hline \multicolumn{4}{|l|}{ Southern Electric ${ }^{\circ}$} \\
\hline Midlands Electricity & General Pubic Utilities \& Cinergy (U.S.) & 1996 & $\$ 2.6$ \\
\hline Manweb $\ldots \ldots \ldots \ldots \ldots \ldots \ldots$ & Scottish Power (UK) & 1995 & $\$ 2.7$ \\
\hline SWEB $\ldots \ldots \ldots \ldots \ldots \ldots \ldots$ & Southern Company (U.S.) & 1995 & $\$ 1.7$ \\
\hline SEEBOARD $\ldots \ldots \ldots \ldots \ldots \ldots$ & Central and South West (U.S.) & 1995 & $\$ 2.5$ \\
\hline NORWEB . & North West Water (UK) & 1995 & $\$ 2.7$ \\
\hline SWALEC & Welsh Water (UK) & 1996 & $\$ 1.3$ \\
\hline
\end{tabular}

${ }^{a}$ Hanson split up its various businesses in 1997. Hanson's various energy operations were consolidated into the company the Energy Group PLC. The Energy Group was purchased by PacifiCorp, of Portland, Oregon, in 1997.

'The Pacific Corp. planned acquisition of Eastern Group has been referred by the UK government to the Monopoly and Mergers Commission for review.

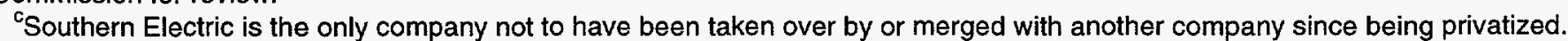
Sources: European Power, McGraw-Hill's Independent Power Report, and The Financial Times, various issues. 
Between the middle of 1995 and early 1997, U.S. utilities have acquired eight of the twelve privatized regional electricity companies. Upon settlement, the value of these transactions will exceed $\$ 25$ billion. British companies have also been aggressive bidders. Four of the remaining six RECs have also been successfully merged with or acquired by UK-based companies.

Although OFFER has generally not interfered with most acquisitions involving the RECs, those involving vertical integration with power generation assets have been controversial. As previously mentioned, in early 1996, there were several attempted generation acquisitions which were in the end rejected by the British government, largely due to concerns over the impacts vertical integration would have on competition.

In October 1995, National Power PLC attempted a takeover of Southern Electric PLC, the second largest regional distribution company in the United Kingdom, for $\$ 4.4$ billion. In turn, at the same time, National Power was reported to be an $\$ 18$-billion takeover target of the U.S.based Southern Company, which had just earlier purchased South Western Electricity. In September 1995, PowerGen, the other major generation company, had mounted a takeover attempt of Midlands Electricity. However, the British government blocked the proposed merger of National Power and Southern Electric (as well as the purchase of Midlands Electricity by PowerGen), due to concerns about competition. In July 1995, Scottish Power placed a \$2.7-billion bid for Manweb (a REC). Scottish Power, however, was not prevented in its takeover of Manweb, suggesting that cross-border vertical integration raised less of a regulatory concern.

Had the Southern Company/National Power merger and the National Power/Southern Electric acquisition gone through, a U.S. utility would have become the largest power generation company as well as the largest distribution company in the United Kingdom. Southern Company would have then owned two of the twelve regional distribution companies (with neighboring territories) along with the largest generation company.

As privatization of UK electricity has unfolded, natural gas transport, distribution, and marketing have also become investment targets of several of the newly-privatized electricity companies (both generators and distributors). Five of the twelve regional distribution companies, along with National Power, have also acquired telecommunications subsidiaries. ${ }^{45}$ Both NORWEB and South Wales Electricity were acquired or merged with local water power utilities with whom they shared service territories. More importantly, all of the privatized RECs and generation companies have obtained natural gas supply operations.

\section{Overseas UK Electricity Industry Investment}

Privatization of electricity in the United Kingdom led to a surge in foreign investment activity in Britain. Similarly, privatization freed UK electricity companies to invest abroad. Led by the two leading power companies, the newly-privatized UK electricity companies have recently undertaken several large overseas investments. In 1996, National Power and PowerGen ranked second and third among the world's largest independent power producers. $^{46}$

In Australia, a consortium led by National Power purchased a 1,600-megawatt coal-fired power plant and adjacent coal mine from the state of Victoria for $\$ 1.8$ billion. ${ }^{47}$ Similarly, a consortium led by PowerGen purchased Australia's Yallourn Energy in Victoria, whose assets consisted of a 1,450-megawatt coal-fired generation facility and adjacent coal mine, also for $\$ 1.8$ billion..$^{48}$ British Energy also bid on a Victorian power plant (the 2,000-megawatt Loy Yang plant) but later withdrew from the bidding. Similarly, Scottish Power dropped out of the bidding for a regional distribution company in Victoria. National Power has also purchased or built electricity facilities in the United States, Portugal, and Pakistan. In its 1995 Annual Report, National Power stated that the company is pursuing electricity investments in Turkey, China, and India. ${ }^{49}$

Meanwhile, PowerGen invested in a 1,220-megawatt coalfired generation facility in Paiton, Indonesia, and a 665megawatt plant in Gujarat, India. PowerGen reports pursuing investment opportunities in India, Thailand, the Philippines, Latin America, and the Middle East. ${ }^{50}$ PowerGen has also made several recent European investments, including a 900-megawatt coal-fired plant in Sckopau, Germany, a 990-megawatt gas-fired station in Portugal, and it has purchased a Hungarian electricity distribution company.

To a more limited extent, the National Grid Company and some of the regional electricity companies have also invested abroad. The NGC purchased part of an electricity transmission system in in Argentina and is developing a transmission line in Pakistan. ${ }^{51}$ Several RECs have also invested abroad. The Energy Group purchased Citizens Power, of Boston, Massachusetts, for $\$ 120$ million. ${ }^{52}$ Midlands Electricity, another REC, is investing in a natural gas-fired 500-megawatt power plant in Ereglisi, Turkey. SEEBOARD, yet another REC, won a contract to refurbish Orissa, India's distribution system, and Norweb purchased shares in a regional distribution system in Argentina. 


\section{Electricity's Relationship to UK Natural Gas Privatization}

Natural gas has played an important and growing role in UK electricity (Figure 6). Between 1989 and. 1995, coal production in the United Kingdom fell by half, while natural gas production increased 74 percent. Britain's move away from coal-fired electric power towards natural gas power is the result of rapidly changing prospects for both of these UK industries. The closure of uneconomic coal mines in the United Kingdom coincides with increasingly available natural gas supplies that have come onstream in the North Sea. Improvements in the efficiencies of combined cycle natural gas turbines used in electricity generation provided added demand. Environmental concerns and pollution abatement laws have also promoted the switch to gas because coal burning has long been a major contributor to air pollution in the United Kingdom. (For a discussion on the switch from coal to natural gas, see the section entitled: "The Demise of the UK Coal Industry and the Dash to Gas.")

\section{Figure 6. UK Electricity Industry Fuel Use, 1988-1995}

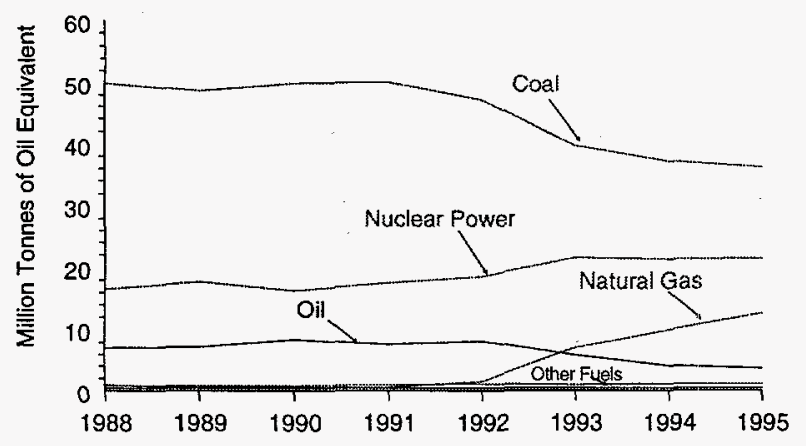

Source: Department of Trade and Industry, 1993-1996.

The privatization and deregulation of the UK natural gas industry has also led to the increase in the use of natural gas in electricity generation. Shortly after passage of the Natural Gas Act of 1986, the UK government sold British Gas. Up until 1986, British Gas dominated natural gas transmission, distribution, and marketing. In addition to privatization, the Natural Gas Act of 1986 required that British Gas' transmission pipelines provide open access for all sellers of gas. The Natural Gas Act also created the Office of Gas (OFGAS), an industry "watchdog" similar to OFFER. Since passage of the act, a substantial number of new suppliers have entered the industry, creating heightened competition.
As in the case of electricity, natural gas marketing in the United Kingdom has been undergoing deregulation in stages. In late 1986, the first stage involved allowing large users of natural gas (over 25,000 terms $^{53}$ a year) to seek alternative sources of marketing. The initial group consisted largely of Britain's industrial users of natural gas. In August 1992, users of natural gas in excess of 2,500 terms (primarily commercial demand) were allowed to bypass British Gas in favor of other suppliers. Both actions greatly diminished British Gas' share in the market for industrial and commercial uses. The final stage of privatization, which began in 1995 with the enactment of the Gas Act of 1995, is currently being implemented.

The Gas Act of 1995 set out the framework for competition in the residential gas market. Following passage of the Act, the UK initiated a free market experiment in natural gas distribution by allowing a half-million residential and small business consumers in three southwestern counties to choose their natural gas suppliers. Previously, the sole supplier of natural gas to these markets had been British Gas. This pilot program is intended to provide a testing ground for the eventual deregulation of the entire natural gas market in the United Kingdom, scheduled to take place in 1998. As of April of 1996, OFGAS had licensed ten companies to market natural gas in the pilot area.

The nature of these companies' operations suggests how dramatically the natural gas industry in the UK is evolving. Included in the ten companies awarded licenses are several U.S. electric utilities, as well as petroleum companies from the United States, Norway, the United Kingdom, and France (Table 9). These companies also include some of the UK's recently-privatized regional electrical companies and PowerGen, one of the two recently-privatized power generation companies.

The petroleum companies entering the UK's newlyopened natural gas distribution business all have substantial North Sea natural gas operations. The primary purpose of obtaining these licenses is to integrate their upstream North Sea operations with the downstream UK residential natural gas market. Amerada Hess, Amoco, Conoco (DuPont), Phillips, and Texaco of the United States; Statoil and Norsk Hydro of Norway; and TOTAL of France, have all obtained licenses or conditional licenses to market natural gas in the newly-opened regions.

A number of electric utility companies (both from the United Kingdom as well as from the United States) have also set up subsidiaries in the newly-deregulated regions. (As noted earlier, some electricity companies have also moved into telecommunications and water distribution.) 
Table 9. Major UK Regional Natural Gas Pipeline Privatizations

\author{
Recent Natural Gas \\ Distribution Licence Applicants
}

Owner/Nationality

\begin{tabular}{ll}
\hline Secured Licenses & \\
Amerada Hess Ltd. & Amerada Hess (U.S.) \\
Beacon Fuels Gas Ltd. & SEEBOARD (UK) \\
British Fuels Gas & Former subsidiary of British Coal (UK) \\
Sterling Gas & East Midlands Electricity (UK) \\
Manweb Gas & Scottish Power (UK) \\
Northern Electric plc & Northern Electric (UK) \\
Midlands Gas Ltd. & Midlands Electricity (UK) \\
Eastern Natural Gas Ltd. & Eastern Group (Hanson) (UK) \\
British Gas Trading Ltd. & British Gas (UK) \\
London Total Energy Company & London Electricity/Total Petroleum (UK/France) \\
NORWEB Gas Ltd & NORWEB (UK) \\
Southern and Phillips Gas Ltd. & Southern Electric/Phillips Petroleum (UK/U.S.) \\
Calortex & Calor/Texaco (UK/U.S.) \\
SWALEC Gas & SWALEC (UK) \\
SWEB Gas & South Western Electricity/Utilicorp (UK/US) \\
Conditional Licenses & \\
Alliance Gas & British Petroleum/Statoil \& Norsk Hydro (UK/Norway) \\
Kinetica & PowerGen/Conoco(UK/U.S.) \\
Southern Gas & Amoco/SEEBOARD (U.S./U.S. \& UK) \\
\hline
\end{tabular}

Notes: Calor is a major marketer of liquefied petroleum gases in the United Kingdom.

These developments may eventuate in the creation of a residential energy service industry in the UK with a variety of single service (e.g., natural gas only or electricity only) and mixed service (e.g., electricity and natural gas) companies. Such a residential energy service industry would be markedly different from the past structure of Britain's electric power and natural gas distribution structures, when two single companies (the CEGB and British Gas) were the sole, but separate, providers of these services.

\section{The Demise of the UK Coal Industry and the Dash to Gas}

Privatization of electricity in the United Kingdom had an important impact upon fuel use in electricity generation. Coal had long been the predominant fuel in electricity generation and the electricity industry had long been the primary purchaser of British coal. ${ }^{54}$ However, between the 1980's and the mid 1990's, developments in the electricity, coal, and natural gas industries, along with changes in the political environment, created an environment that favored the use of natural gas (rather than coal) to become the preferred fuel of choice in UK electricity generation.
Prior to the privatization of electricity, the cost of domestic coal to electric utilities far exceeded the cost of coal traded in international markets. For a variety of political and economic reasons coal has assumed a special place in the UK's economy and polity ever since the UK entered the Industrial Revolution. Between 1984 and 1985, the UK experienced a year-long coal mining strike-an event which would subsequently significantly reduce the political influence of the UK coal miners' union and the longterm viability of the industry. At the time, Margaret Thatcher was the prime minister, and conservative governments in the UK had long had a confrontational relationship with the coal miners' union. However, the strike additionally served to alienate much of the nation from the coal miners' union.

Electricity privatization also reduced the power of the UK coal mining industry itself. The replacement of the more publicly- accountable Central Electricity Generation Board (CEGB) as the primary purchaser of UK coal with the newly-privatized generation companies, National Power and PowerGen, weakened the bargaining power of British Coal, the national coal company. The former relationship, whereby the CEGB largely subsidized the UK coal industry through purchasing domestic coal at above world market rates and then passing through those costs to consumers, would eventually end. 
In 1990 (during the creation of National Power and PowerGen), the UK government renegotiated its contract with British Coal so that both the volume of purchases and the price declined over 3 years. During the first three years after privatization, generators were required to purchase a set quantity of British coal at set prices; however, both prices and quantities of coal were to be substantially reduced over the contracted period. In turn, the generators could still pass on these higher prices, but only to the regional electricity companies' franchised market. Expectations at the time saw coal imports taking up the slack.

By the fall of 1992, British coal had reached a crisis stage. Several factors led to this, including growing competition from increasingly available natural gas: the imminent removal of the regional electricity companies' captive franchise supply market; a more assertive National Power and PowerGen; newly-enacted pollution abatement goals; and ample coal stocks at electric utilities. As the deadline for the first three-year contract approached, the government initially recommended even greater reductions in electricity industry coal purchases from British Coal than those negotiated for in the first three-year contract. Large reductions in prices were also expected. The new contract called for annual coal supply to be reduced to 30 million metric tons by the 1994/1995 fiscal year time period, or to less than half the 81-million ton level in the $1989 / 1990$ fiscal year time period..$^{55}$

When it became clear that these proposals would result in massive coal employment losses in coal production, a Parliamentary crisis ensued. By March of 1993, however, the crisis had largely dissipated and the British government was able to push through most of its earlier proposals, with only a few meaningful alterations. ${ }^{56}$ The resulting coal contracts required National Power and PowerGen to purchase 40 million tons of coal in the first year of the contract and only 30 million tons in each of the four years that followed ${ }^{57}$ Furthermore, when British Coal was privatized in 1994, it was done so with government expectations that it would eventually operate as a competitive company and not be dependent upon government subsidy.

Coal production at British mines fell from 84 million tons in 1988 to 35 million tons in $1995 .^{58}$ In 1988 , coal (on a crude oil equivalent basis) accounted for 66 percent of fuel use at UK electric utilities (Figure 6). By 1995, this share had fallen to 48 percent. By 2010, coal's share of electricity production is expected to fall to 31 percent. $^{59} \mathrm{Coal}$ industry employment has clearly reflected the decline in energy consumption. In the 1981/1982 fiscal year time period, 184,400 workers were employed by the coal industry. This number had fallen to 11,000 by $1995 .^{60}$
Much of the reduction in coal consumption has been made up for by a greater dependence on natural gas. The demise of the British coal industry is closely interlinked with both the privatization of electricity and the developments in the UK's natural gas industry. Prior to the privatization of natural gas, natural gas use in electricity generation was discouraged. ${ }^{61}$ Furthermore, after British Gas (the former state-owned natural gas monopoly) was privatized, the UK natural gas market grew more competitive, leading to ample supplies and reduced prices. The natural gas share of utility fuels rose from 1 percent in 1988 to 17 percent in 1995 . By 2010, natural gas is expected to account for 46 percent of fuel use at electric power plants. $^{62}$

Allowing the regional electricity distribution companies to enter into the power business encouraged them to find quick power generation alternatives to the electricity pool. Combined cycle natural gas turbines provided the quickest means of entry into the generation market due to their low construction costs and short lead times. Due to efficiency improvements and the startup of a new reactor, nuclear power has also partly displaced coal. Between 1988 and 1995, nuclear's share of generation rose from 22 percent to 28 percent.

Environmental considerations also worked against UK coal in recent years. In 1988, the United Kingdom ratified a European Community directive requiring a 60-percent reduction in total sulfur dioxide emissions by 2003 , compared to 1980 emissions levels. ${ }^{63}$

\section{Independent Power Producers in the United Kingdom}

In recent years, independent power producers (IPPs) have played an increasingly important role in electricity generation in the United Kingdom (Table 2). Companies from the United States have also been major investors in independent power projects in the United Kingdom. The independent power production industry owes its existence to passage of the Electricity Act of 1983, which provided new electricity producers with access to the national grid, and to passage of the 1989 Electricity Act which made that access non-discriminatory. All of the RECs have formed independent production subsidiaries, as have National Power, PowerGen, Scottish Power, and Hydro Electric. The RECs' IPPs account for roughly half of the recent additions to generation capacity in England and Wales. ${ }^{64}$ Several foreign (and mainly U.S.-based companies) have also been very active in the UK's IPP industry (Table 10). A favored form of generation for independent power-producing companies has been the combined cycle natural gas turbine electric facility. This is in part due to the improved economics of natural gas as 
Table 10. Major Foreign Equity Investments in UK Independent Power Projects

\begin{tabular}{|c|c|c|c|}
\hline Project Site & Megawatts & Equity Share $^{a}$ & Company/Companies Involved \\
\hline Teesside & 1,875 & 50 & Enron (U.S.) \\
\hline \multirow[t]{2}{*}{ Medway ............... } & 660 & 38 & SEEBOARD \\
\hline & & 38 & AES (U.S.) \\
\hline Brigg South Humberside .... & 240 & 25 & IVO (Finland) \\
\hline Dinorwig . ............. & 1,728 & 100 & Mission Energy (U.S.) \\
\hline Derwent & 214 & 33 & Mission Energy (U.S.) \\
\hline$\ldots \ldots \ldots \ldots \ldots$ & 360 & & Mission Energy (U.S.) \\
\hline \multirow[t]{3}{*}{ Humber Power ........... } & 750 & 30 & IVO (Finland) \\
\hline & & 30 & Tomen (Japan) \\
\hline & & 20 & ABB (Swedish/Swiss) \\
\hline \multirow[t]{2}{*}{ Aylesford } & 58 & & ABB (Swedish/Swiss) \\
\hline & & & Meekatharra (Australia) \\
\hline Barry ................. & 250 & & AES (U.S.) \\
\hline Brigg $\ldots \ldots \ldots \ldots \ldots \ldots$ & 240 & 25 & IVO (Finland) \\
\hline Indian Queens . . . . . . . . & 140 & & Destec (U:S.) \\
\hline Isle of Grain . & 675 & 25 & AES (U.S.) \\
\hline \multirow[t]{3}{*}{ South Humber Bank . . ..... } & 1,320 & 30 & IVO (Finland) \\
\hline & & 25 & Tomen (Japan) \\
\hline & & 20 & ABB (Swedish/Swiss) \\
\hline Spondon & & 33 & Mission (U.S.) \\
\hline Sutton Bridge . . . . . . . . . & 700 & & Enron (U.S.) \\
\hline 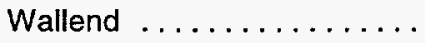 & 750 & 100 & Enron (U.S.) \\
\hline
\end{tabular}

${ }^{a}$ Note: Equity shares do not always total to 100 percent due to the unreporting of some ownership shares.

Source: UK Electricity Association, Generation Projects since Privatization, http://www.electricity.org.uk/inds_fr.html, 1997.

an electric fuel. The improved efficiency of natural gas turbines and the short lead time needed to construct a combined cycle gas turbine facility have also encouraged the IPP move into natural gas. Since Vesting Day, combined cycle gas turbines have provided 12,978 of the 14,738 megawatts of new generation capacity scheduled to be completed by the end of 1996 in England and Wales. ${ }^{65}$ For the RECs, the combined cycle natural gas turbine provided the quickest means of entry into the power generation business.

Natural gas and IPPs have grown hand in hand in providing future growth in the UK's electric generation capacity. In the 1990/1991 fiscal year time period, the IPPs accounted for roughly 1 percent of the UK's electricity generation capacity. By the 1995/1996 fiscal year time period, the IPPs increased their share of total UK generation capacity to 15 percent and are expected to account for 21 percent of this UK capacity by the $2000 / 2001$ fiscal year time period (Table 2).

\section{Privatized Electricity: A Performance Appraisal}

In the seven years since privatization began, the UK electricity industry has clearly become more efficient. In 1995, the United Kingdom produced 8 percent more electricity than in 1988.66 Between the $1989 / 1990$ and $1995 / 1996$ fiscal year timeframes, employment in the UK electricity industry was reduced by roughly fifty percent (Table 11). Reductions in prices as a result of the periodically scheduled regulatory reviews clearly had an impact on later price reductions to electricity consumers. Although consumers have generally experienced lower inflation-adjusted electricity prices since privatization, Figure 7 indicates that gains to larger consumers have generally exceeded those to households.

However, other factors have also played a role in retail electricity price reductions. Prior to Vesting Day, UK 
Table 11. Employment in the UK Electricity Industry, Selected Years

\begin{tabular}{|c|c|c|c|}
\hline Segment & $1989 / 1990$ & $1994 / 1995$ & $1995 / 1996$ \\
\hline National Power \& PowerGen & 82,478 & 62,948 & 54,469 \\
\hline National Grid $\ldots \ldots \ldots \ldots \ldots \ldots \ldots \ldots$ & 26,407 & 9,618 & 8,996 \\
\hline Regional Electricity Companies $\ldots \ldots \ldots \ldots$ & 14,415 & 9,426 & 4,907 \\
\hline Total $\ldots \ldots \ldots \ldots \ldots \ldots \ldots \ldots \ldots \ldots$ & 123,300 & 81,992 & 68,372 \\
\hline
\end{tabular}

Note: The National Electricity Code. <http://acc.gov.au/sched/httoc.htm7>.

Source: Electricity Association, Electricity industry Review (January 1997), p. 54.

Figure 7. Index of UK Electricity Prices, 1988-1995

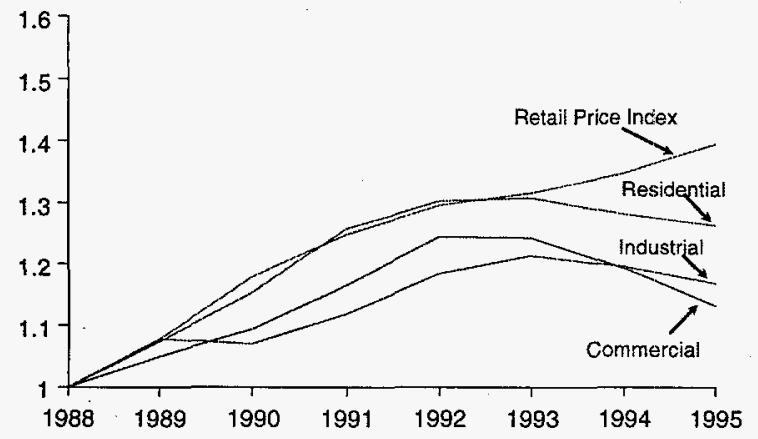

Note: $1988=1.00$. Values listed are in current monetary units.

Source: Department of Trade and Industry, Digest of the United Kingdom Energy Statistics, 1993-1996.

regulators allowed for significant electricity price increases (which made later price reductions by the industry easier to achieve), in part to increase the attractiveness of the soon-to-be privatized electricity industry. Fuel costs have also decreased since privatization. The price of the most heavily used fuel in electricity generation-coal-has fallen even in nominal terms (Figure 8). Natural gas prices in the United Kingdom have also trailed the overall rate of price inflation.

Deregulation in the United Kingdom was driven by the belief that electricity prices were held artificially high due to the inefficient operation of government-owned electric utilities. The government could have attempted to close this price gap via stricter regulation, but instead chose competition and price caps as a means of reducing electricity prices. In part, this decision stemmed from the belief that the regulated utilities were better equipped than the regulator to know what kind of efficiency improvement measures could be undertaken once they had an incentive to make them.

The other factor is political. Much improvement in the efficiency gains in UK electricity were achieved through massive workforce reductions. Under the old style of regulation, it is highly unlikely that the regulator could have dictated such workforce reductions to the utilities, given
Figure 8. Fuel Price Index for UK Electric Utilities, 1988-1995

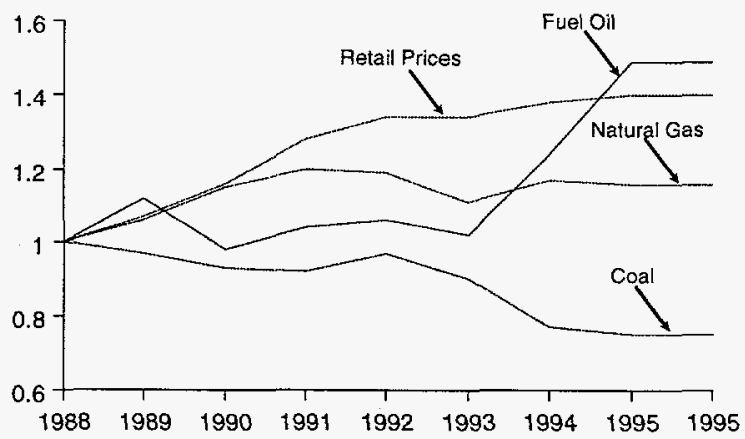

Note: $1988=1.00$. Values listed are in current monetary units. Source: Department of Trade and Industry, Digest of United Kingdom Energy Statistics, 1993-1996.

that the then regulator (a public official) would have been held publicly accountable for the rising unemployment. ${ }^{67}$

\section{A Light-Handed Approach to Electricity Regulation?}

The Electricity Act of 1989 created an Office of Electricity Regulation (OFFER), which has primary responsibility for electricity regulation. The 1989 act also created the position of Director General of Electricity Supply, providing a single individual with responsibility for electricity regulatory activity. ${ }^{68}$ The initial (and current) director is Stephen Littlechild, a former professor of commerce. The Director's term of office was set at five years. Littlechild was appointed to his first term of office in 1989 and reappointed in 1994. Littlechild has long been associated with incentive regulation, and has been a strong proponent of replacing rate-of-return regulation with price cap (or RPI-X) regulation. ${ }^{69}$ This regulatory approach has frequently been characterized as being "light-handed."

The OFFER's missions are to assure that an adequate level of electricity supply be available; that the industry remain competitive; and that organizations licensed (by the OFFER) to engage in electricity operations be capable of financing those operations. The OFFER has similarly 
structured regulatory watchdog counterparts in the recently-privatized UK natural gas industry (OFGAS), the recently-privatized UK telecommunications industry (OFTEL), and the recently-privatized UK water industry (OFWAT).

The UK approach of having a single official responsible for regulation differs considerably from the regulatory approach most commonly practiced in the United States, where various regulatory commissions (with several commissioners) have oversight authority. At the national level in the United States, the Federal Energy Regulatory Commission (FERC), an independent agency within the U.S. Department of Energy, has jurisdiction over interstate electricity sales and wholesale electric rates. The FERC's policy-setting arm consists of one chairperson and four commissioners. Primary responsibility for electricity regulation in the United States resides with individual state public utility regulatory commissions.

Although the Director General of OFFER is clearly more independent and has more discretion over policy making than his U.S. counterpart, the UK's system of single person authority has been criticized for lacking debate. Access for UK electric utility producers and consumers to petition OFFER is also less than in the United States, making the UK electricity policy decision-making process perhaps less accountable than that which exists in the United States. The single-person regulatory approach has also tended to personalize both the OFFER and the decision-making process, possibly causing the UK regulatory regime somewhat of a credibility problem. ${ }^{70}$

Another difference between the UK and U.S. models concerns the prominent role that local governments (or states) play in regulating electricity. At the state level, elected officials usually appoint public utility commissions (PUCs) to exercise regulatory oversight. ${ }^{71}$ There is no equivalent counterpart to these commissions in the United Kingdom where regulatory matters are handled exclusively at the national level. In comparison to the situation in the United States, the UK Director General has a relatively lean staffing level-a purposeful advantage of the UK model. The task of regulating the entire UK electricity industry falls on OFFER's staff of slightly more than two hundred employees. In contrast, the California public utility commission (PUC) alone has employment of roughly 900, although the California PUC also regulates water and telecommunications. ${ }^{72}$

The OFFER is not the only government agency having oversight authority over the UK electricity industry. Two other agencies also engage in some supervisory role. The Monopoly and Mergers Commission (MMC), through its authority to conduct and rule on antitrust investigations, has substantial political influence. The Office of Fair Trade, whose purpose is to promote and safeguard economic interests of consumers, also has a say in electricity industry matters. Further, the Department of Trade and Industry has some influence over electricity regulatory matters since its most senior official (the Secretary of State) is responsible for appointing the Director General of the OFFER. ${ }^{73}$

The OFFER is responsible for determining the appropriate price caps and their durations for the regulated portion of the UK electricity industry. Although generation is nominally unregulated, OFFER can (and has) exerted influence over the electricity generation sector. An option available to OFFER is the right to propose an MMC investigation into any portion of the industry OFFER deems not competitive. The OFFER used its authority to intervene in setting pool prices in 1994 when it implemented a price cap. The OFFER also required that National Power and PowerGen sell off 6,000 megawatts of electricity generation capacity when concerns over market dominance in electricity supply were raised.

The OFFER has been a target of criticism by both UK consumers of electricity and the electricity industry itself. Consumers have voiced complaints that OFFER's choices of productivity $(X)$ factors have been too favorable to the industry and have led to excessively high profits. In contrast, electricity producers have criticized the OFFER for increasing electricity regulation through its unscheduled reviews of price rate structures.

Industry's criticism of the OFFER has to do with the agency's lack of commitment to its previous regulatory decisions. In March of 1995, OFFER reopened its price review on the distribution companies after putting forth an initial August 1994 proposal regarding one-time rate reductions and " $X$ " factors. Precipitating OFFER's unscheduled price review was a takeover attempt of Northern Electric (a REC) by Trafalgar, coming shortly after the initial OFFER price cap proposals for the second review period had been released. Northern's resistance to the takeover attempt included a stock buyback, a move which suggested to the financial community that Northern's financial position was much better than indicated by previous assessments. The reassessment of Northern's value instigated a reassessment of the entire value of all of the UK regional electricity distribution companies. In a decision which appeared to be a reaction to these reassessments, the OFFER later tightened its previously-proposed rate caps and one-time revenue reductions for the 1995 to 2000 review period, an action which at the time was seen by the industry as evidence of a lack of commitment by the OFFER. 


\section{Performance-Based Utility Regulation}

Issues of fairness and equity have dogged performancebased ( RPI-X) price-cap regulation since its inception in the United Kingdom (for a detailed discussion on RPI- $X$ regulation, see the section entitled: "RPI-X: Price Caps Versus Rate of Return Regulation"). In privatizing and reforming their electricity industry, the UK government undertook an experiment. Initially, neither the government (nor perhaps the industry) expected cost reductions of the magnitude that were eventually achieved.

The major regulatory problem in implementing RPI-X has been determining (or discovering) what the appropriate level of initial prices and the appropriate " $X$ " factors should be. OFFER's decisions regarding appropriate starting rates and " $X$ " factors during the industries' periodic reviews indicates a strong asymmetry of knowledge of the industry between regulator and regulated. In retrospect, it is clear that the regulator had a propensity to underestimate the industries' potential for achieving cost reductions.

However, at the same time, it is reasonable to assume that this same propensity to underestimate would have occurred had the regulator operated under traditional rate-of-return regulation, making it even more doubtful that the efficiency gains actually realized would have been achieved had the industry not been given a strong financial incentive to cut costs. (It should be noted though that the generation companies also realized large efficiency gains following privatization, although these companies were essentially unregulated.) Clearly, RPI-X has produced very large efficiency gains in UK electricity distribution and transmission. In a sense, RPI- X's usefulness as an efficiency improvement tool was undone by its own success.

The UK's experience with RPI-X has clearly influenced regulatory reform in Argentina and Australia (See Chapters 3 and 4). It may have also influenced recent regulatory reform in the United States. In recent years, several public utility commissions in the United States have adopted a hybrid form of both price cap regulation and rate-of-return regulation, with the difference between price cap regulation and rate-of-return regulation becoming a matter of emphasis. ${ }^{74}$ Several variations of the hybrid exist. However, regardless of the variation, in essence the hybrid method allows utilities to keep only a share of the gain realized from cost cutting, the remainder being turned over to the rate payers more immediately. Advocates of a "sliding scale" method of regulation feel it to be a more fair system because it immediately shares a portion of the gain with consumers. Critics feel it reduces potential efficiency gains because it presents companies with less incentives to cut costs and in the end simply provides consumers with just a larger slice of a smaller cake.

The California Public Utilities Commission recently employed a form of "sliding scale" regulation which allocates efficiency gains between electricity companies and consumers. Within a bandwidth of 50 to 300 basis points of the benchmark, consumers would accrue up to 25 percent of the gains. Stockholder's gains would vary from 25 percent to 100 percent of the gain beyond the 300 points. $^{75}$

Early efforts at cost cutting did enable the National Grid Company and the regional electricity distribution companies to greatly improve their financial performances, which, in turn, raised public concerns over the fairness of the new system. Net income for the National Grid Company and the twelve regional distribution companies increased by more than 50 percent between the fiscal year $1985 / 1986$ and the 1992/1993 fiscal year time periods (Table 12). ${ }^{76}$ However, during the first three years of implementation (1990 to 1993), promised benefits to residential users appeared elusive. Household electricity prices rose slightly more than overall retail price inflation during this period despite a decline in steam coal prices for electricity generation (Figures 7 and 8). The fact that shareholders reaped large dividends during the utilities' initial public offerings also gave rise to questions of fairness. Large increases in executive compensation in the face of wide-scale labor force reductions compounded the matter further.

A large part of the problem stemmed from the UK government's initial choice of $X$-which, depending on the REC, ranged from zero to a negative 2.5 percent (Table 13). At the time it was felt that the industry needed to make extensive capital investments over the coming years and thus needed a secure cash flow. As stated earlier, a generous $X$ also made companies more attractive to shareholders, thereby increasing their auction value. In any event, the industry's high level of profitability during the first period resulted in OFFER proposing more severe price caps for the second regulatory cycle. OFFER called for a one-time reduction in REC prices of between 11 and 17 percent and an $X$ of a positive 2 percent. ${ }^{77}$

In March 1995, the OFFER announced a more stringent price reduction and $X$ factors. This action gave rise to concerns that the new regulatory regime lacked a sense of commitment. Whereas the distribution of economic rents realized during the first regulatory cycle tended to reduce consumer confidence in the new arrangement, OFFER's eversal on earlier price benchmark and $X$ factor proposals was a source of concern for industry. Whereas the former event illustrates the difficulties that may be encountered if the initial price caps are inadequate, the latter event 
Table 12. Net Income for UK Electricity Generation Companies, Selected Years (Million Dollars)

\begin{tabular}{|c|c|c|c|c|c|}
\hline Company & $85 / 86$ & $88 / 89$ & $89 / 90$ & $92 / 93$ & $94 / 95$ \\
\hline CEGB . & 1,229 & $-4,751$ & & & \\
\hline National Power & & & 279 & 911 & 1,107 \\
\hline PowerGen ...... & & & 367 & 667 & 856 \\
\hline Nuclear Electricity & & & $-1,457$ & 171 & 1,677 \\
\hline National Grid .... & & & 674 & 837 & 959 \\
\hline REC's Distribution $\ldots \ldots \ldots \ldots \ldots \ldots \ldots$ & & & 914 & 1,501 & 1,753 \\
\hline REC's Marketing $\ldots \ldots \ldots \ldots \ldots \ldots \ldots$ & & & 157 & 273 & 377 \\
\hline Total $\ldots \ldots \ldots \ldots \ldots \ldots \ldots \ldots \ldots$ & 1,229 & $-4,751$ & -137 & 2,586 & 4,599 \\
\hline
\end{tabular}

Source: Michael Brower, Stephen Thomas, and Catherine Mitchell, "Lessons from the British Restructuring Experience, The Electricity Journal (April 1997), Gordon Mackerron and Jim Watson, "The Winners and Losers So Far," The British Electricity Privatization Experiment, Privatization: The Record, the Issues, the Lessons, ed. John Surrey (London, England: Earthscan Publications Limited, 1996), p. 199.

Table 13. The Initial Regulation of Electricity Distribution

\begin{tabular}{|c|c|}
\hline $\begin{array}{c}\text { Regional } \\
\text { Electricity Company }\end{array}$ & X Factor \\
\hline London . . . . . . . . . . & 0.00 \\
\hline Manweb ........... & -2.50 \\
\hline NORWEB . . . . . . . . & -1.40 \\
\hline Southern $\ldots \ldots \ldots$. & -0.65 \\
\hline SWEB $\ldots \ldots \ldots \ldots \ldots$ & -2.25 \\
\hline East Midlands Electricity & -1.25 \\
\hline Eastern Group . . . . . . . & -0.25 \\
\hline Midlands Electricity .... & -1.15 \\
\hline SEEBOARD $\ldots \ldots \ldots$ & -0.75 \\
\hline SWALEC $\ldots \ldots \ldots \ldots$ & -2.50 \\
\hline Yorkshire Electricity .... & -1.30 \\
\hline Northern Electric . . . . . & -1.55 \\
\hline
\end{tabular}

Source: Thomas Weyman-Jones, "Problems of Yardstick Regulation in Electricity Distribution," The Regulatory Challenge, eds. Matthew Bishop, John Kay, Colin Mayer (Oxford University Press: London, 1995), p. 429.

highlights the commitment problem in policy making-or the efficacy of any particular policy when it fails to endure political opposition. Investment decisions can be jeopardized by the uncertainty created when the commitment of the regulator is called into question. This could create an unacceptably uncertain investment environment. ${ }^{78}$ Further, when public concerns over industry profitability induces unscheduled industry reviews, RPI-X may in reality approximate rate-of-return regulation-just by another name.

\section{Was RPI-X the Right Choice?}

Politically, it is not clear whether RPI-X regulation will survive the recent change in the UK government. Tony Blair, the Labor Party leader and new prime minister, had in May of 1995 called for a replacement of RPI-X by a regulatory formula that "shares excess profits between utilities and customers. ${ }^{\prime 79}$ Since assuming office, the new prime minister has proposed a windfall profits tax on recently privatized public utilities. ${ }^{80}$ The fact that the new form of regulation became so politically untenable with a change in government questions its efficacy as a means of public policy.

Despite the perceived problem with "fairness" which has dogged RPI-X regulation, it is doubtful that the efficiency gains realized through its implementation could have been achieved via the more traditional rate-of-return type of regulation. The major problem in implementing RPI-X has related to the regulator's determination of the appropriate level of initial prices and what the appropriate $X$ factors should be. If, for instance, the regulator had greatly underestimated both, would using a rate-of-return style of regulation have added in any material way to the regulator's ability to predict future potential cost reductions? This question deserves consideration, especially given that a rate-of-return style of regulation would have offered few incentives for the utilities to maximize those cost reductions. 


\section{Endnotes}

${ }^{1}$ Paul Cook, The British Council, Governance and Law, The Evolution and Performance of UK Privatization, INTERNET address: http://www.britcoun.org/governance/briefing/iss 2 int.htm.

${ }^{2}$ "Sale of the Century," The Wall Street Journal (October 2, 1995), p. R17.

${ }^{3}$ Often times the marketing function of the electricity industry is subsumed in the distribution segment. However, certain services normally provided by distribution companies can be separated out. These services include such items as brokering, billing, and metering. As stated earlier, the marketing segment of the electricity industry along with generation was considered to be potentially competitive and deregulated gradually. It should be noted that in the United Kingdom, the conventional term for the provision of these services is "supply" rather than "marketing".

${ }^{4}$ A single-firm "natural monopoly" industry is warranted when the operating costs of an industry are lower with a single supplier. See: Alfred E. Kahn, "The Economics of Regulation", (The MIT Press, Cambridge Massachusetts: 1988), p. 11/1.

s“'Time's Up for Greedy Bosses," The Daily Mail, March 1, p. 1.

${ }^{6}$ John Chesshire, "UK Electricity Supply Under Public Ownership, "The British Electricity Privatization Experiment, Privatization: The Record, the Issues, the Lessons, ed. John Surrey (London, England: Earthscan Publications Limited, 1996), p. 15

${ }^{7}$ For background information on the history of the British Electricity industry see, Regulating Utilities: A Time for Change?, ed Colin Robinson (London, England: Institute of Economic Affairs, 1996), pp. 109-144 or The British Electricity Privatization Experiment, Privatization: The Record, the Issues, the Lessons, ed. John Surrey (London, England: Earthscan Publications Limited, 1996).

${ }^{8}$ According to Robinson, the industry had become both "an instrument of government policy and government industrial policy." Regulating Utilities: A Time for Change?, ed Colin Robinson (London, England: Institute of Economic Affairs, 1996), p. 111.

9John Chesshire, "UK Electricity Supply Under Public ownership, The British Electricity Privatization Experiment, Privatization: The Record, the Issues, the Lessons, ed. John Surrey (London, England: Earthscan Publications Limited, 1996), p. 19.

${ }^{10} J$ John Chesshire, "UK Electricity Supply Under Public ownership, "The British Electricity Privatization Experiment, Privatization: The Record, the Issues, the Lessons, ed. John Surrey (London, England: Earthscan Publications Limited, 1996), p. 19.

${ }^{11}$ The semi-autonomous relationship of the former regional distribution boards to the rest of the industry was one reason why vertical deintegration was more easily achieved in the United Kingdom than in other countries.

${ }^{12}$ In additions to the recently privatized elements of the electricity industries in the UK, other participants in UK electricity include independent power producers and Electricity de France. In 1995, the UK imported roughly 2 percent of its electricity from France via its 2000 megawatt link to France. Source: Department of Trade and Industry, Digest of the United Kingdom Energy Statistics, 1996, p. 99.

${ }^{13}$ In the United Kingdom, costs associated with the privatized, deregulated electricity industry are often expressed in budgetary time periods (i.e., April 1 to April 1 fiscal years) and not calender year time periods. Thus, for the purposes of this report, 19xx/19yy will refer to particular fiscal years and $19 \mathrm{xx}-19 \mathrm{yy}$ will refer to particular calender years.

${ }^{14}$ Nuclear Electric, which was to remain under public ownership, accounted for 17 percent of generation capacity. During the initial debate over privatization, the viability of the nuclear power industry as a private entity came into question. As in the United States, the issue of stranded cost liabilities was an important issue in the debate on industry restructuring in the United Kingdom. The initial plan called for the coupling of thermal and nuclear assets as a means of encouraging investor acceptance. National Power was to be given all of the UK's nuclear power plants along with roughly half of the country's non-nuclear capacity. This plan, however, was latter dropped when it became apparent that the financial liabilities of nuclear power made early privatization unfeasible. Nuclear power was to remain under public ownership, but under a new company name, Nuclear Energy. Plans to privatize nuclear power were postponed although a portion of the industry was eventually privatized in 1996 as the company British Energy (for a discussion on the issue of stranded costs and nuclear power in the United Kingdom, see box entitled: "Nuclear Power and the Issue of Stranded Costs").

${ }^{15}$ Green, R.J. and Newberry, D.M. "Competition in the Electricity Spot Market," Journal of Political Economy, vol. 100, no. 5, October, pp. 929-953.

${ }^{16 ،}$ The Busiest Merger Lab: The UK Electricity Sector," Electrical World, Vol. 210, No 7 (New York, New York, July 1996), p. 29.

17"The Busiest Merger Lab: The UK Electricity Sector," Electrical World, Vol. 210, No 7 (New York, New York, July 1996), p. 29.

18“"The Busiest Merger Lab: The UK Electricity Sector," Electrical World, Vol. 210, No 7 (New York, New York, July 1996), p. 29.

${ }^{19}$ In February of 1997, the conglomerated Hanson split up its various businesses and consolidated its energy holdings in the newly created company the Energy Group. The Energy Group is the largest private producer of coal in the world and owner of Peabody Holding Co, the largest U.S. coal company. In June 1997, PacifiCorp, of the United states, purchased the Energy Group.

${ }^{25}$ The REC's franchised operations consisted of the below 1 megawatt users of electricity in each of the geographical territories assigned to the former Area Boards.

${ }^{21}$ The initial non-franchised marketing market applied to the $>$ megawatt consumer of electricity.

${ }^{22}$ Customers whose electricity demand ranged from $<1$ megawatt and $>1$ kilowatt.

${ }^{23}$ Customers whose electricity demand $<1$ kilowatt.

${ }^{24}$ Petroleum Times, July 1, 1991, p. 4.

${ }^{25}$ Internal document, Smith New Court United Kingdom.

${ }^{26}$ Internal document, Smith New Court United Kingdom.

${ }^{27}$ Nuclear Electric participates in the pool but as a passive price taker.

${ }^{28}$ Alex Henney, Electricity Journal, January/February 1997

${ }^{29} \mathrm{CFDs}$ are similar in many ways to forward contracts in that they are generally bilateral contracts and often non-standardized. They are also similar to futures contracts in that they are purely financial instruments (i.e., no delivery of electricity takes place) and they are hedges against future price changes. See: Alex Henney, The Privatization of the Electricity Supply Industry in England \& Wales (London, England: EEE Limited, 1994), p. 350-351.

${ }^{30}$ Steve Thomas, "The development of Competition," The British Electricity Privatization Experiment, Privatization: The Record, the Issues, the Lessons, ed. John Surrey (London, England: Earthscan Publications Limited, 1996), p. 82.

${ }^{31}$ Colin Robinson, "Profit, Discovery, Entry:The Case for Electricity," Regulating Utilities: A Time for Change?, ed. M. E. Beesley (Wiltshire, England: Redwood Press, 1996), pp. 128-129.

${ }^{32}$ A natural monopoly is defined as a situation where "a single firm can serve the market at lower unit casts than two or more firms." F.M. Scherer, Industrial Market Structure and Economic Performance, Second Edition (Chicago, Illinois: Rand McNally College Publishing Company, 1980 ), p. 482. 
${ }^{33}$ There is also the issue of regulatory lag. Regulatory lag refers to the period between a rate-case review (after the regulator has agreed upon a base-case) and the next review, when utilities have an incentive to operate more efficiently than what was assumed during the base-case. Through efficiency gains, utilities can realize greater rates of return than those anticipated during the initial rate review. However, although frequent rate reviews can reduce regulatory lag, such reviews might also make long-run investment planning more difficult. In the extreme, regulatory lag could transform rate-of-return regulation into a form of rate-cap regulation.

${ }^{34}$ In the case of expected future productivity declines, the formula in essence would become RPI+X.

${ }^{35}$ Ray Rees and John Vickers, "RPI-X Price-cap Regulation," The Regulatory Challenge, ed. Matthew Bishop, John Kay, and Colin Mayer (Oxford University Press, London, 1995), p. 376.

${ }^{36}$ It should be noted that in rate-of-return regulation, during the interim period between regulatory reviews, utilities have an incentive to cut costs and thereby boost profits. The more infrequent the regulatory review, the stronger this incentive becomes.

${ }^{3}$ In RPI-X, regulation incentives exist for the industry to encourage a passive form of regulation and favorable $\mathrm{X}$ factors. Although the initial $\mathrm{X}$ factors imposed on the industry have generally been favorable to the industry, that the regulator, OFFER, has engaged in several unscheduled interventions suggests that regulatory capture has not occurred. See: Ray Rees and John Vickers, "RPI-X Price-Cap Regulation," The Regulatory Challenge, ed. Matthew Bishop, John Kay, and Colin Mayer (Oxford University Press, London, 1995), p. 382.

${ }^{38}$ There are several means of reducing public ownership and control and increasing private ownership and control. One option is to have a public auction with no limitations placed on participants. Another option is to conduct the auction but to limit participation, for instance, to citizens. A company may be sold off partly or fully. A company may be sold off to another company or there maybe restrictions placed on the share of any individual purchase. A company may be privatized simply by issuing ownership shares (vouchers) to all citizens or to selected groups of citizens (e.g., employees). Other more passive forms of reducing government control (but not ownership) include deregulation, the removal of subsidies, and the lifting of restrictions on competitions (e.g., from foreign companies). For more detail on the various privatization methods recently employed around the world, see: Energy Information Administration, Privatization and the Globalization of Energy Markets (DOE/EIA-0609) (Washington, DC, October 1996).

${ }^{39}$ Catherine Price, "Gas Regulation and Competition: Substitutes or Complements?" Privatization and Economic Performance, ed. Matthew Bishop, John Kay and Colin Mayer (Oxford, England, Oxford University Press, 1994), p. 137 and Tim Jenkinson and Colin Mayer, "Privatization in the UK and France," Privatization and Economic Performance, ed. Matthew Bishop, John Kay and Colin Mayer (Oxford, England, Oxford University Press, 1994 ), p. 293.

${ }^{40}$ Alex Henney, "The Restructuring and Privatization of the Electricity Supply Industry," The Privatization of Public Utilities, ed Leonard S. Hyman (Public Utilities Reports, Vienna, Virginia), p. 253.

4l"Sale of National Power, PowerGen Shares Seen as "Wildly Successful," "Independent Power Report (March 29, 1991), p. 10.

${ }^{42} \mathrm{John}$ Surrey, "Unresolved Issues of Economic Regulation," The British Electricity Privatization Experiment, Privatization: The Record, the Issues, the Lessons, ed. John Surrey (London, England: Earthscan Publications Limited, 1996), p. 235.

${ }^{43}$ Mission Energy is a subsidiary of Edison International, the parent of Southern California Edison, the second largest electric utility in the United States.

44،"DTI to Keep Share in Electricity," Times Newspaper (May 3, 1996), p. 19.

${ }^{45}$ Electricity Association, Electric Industry Review (January 1997), p. 6.

46"Global Independents Power Capacity Hits 113,447 megawatts; Asian Players Gain," Electric Utility Week (July 29, 1996), p. 13. The ranking is measured by net project ownership but not company portfolios with a preponderance of in-house generation, state-funding or vintage capacity.

${ }^{47}$ Privatization International (September 1, 1996), p.1

${ }^{48}$ PowerGen, 1996 Annual Report, p. 12.

${ }^{49}$ National Power, 1996 Annual Report, p. 3.

${ }^{50}$ PowerGen, 1996 Annual Report, p. 14.

${ }^{51}$ National Grid Home Page, http://www.hgc.co.uk.

${ }^{52}$ The Energy Group is the parent of the Eastern. Group REC. The Eastern Group is also the world's largest private coal producer and owner of Peabody, the largest producer of coal in the United States. Source: PR Newswire (May 20, 1997).

${ }^{53} \mathrm{~A}$ therm is equivalent to one hundred thousand Btu.

${ }^{54}$ In 1995 , the electricity industry purchased over three quarters of all UK coal production. Source: Department of Trade and Industry, Digest of United Kingdom Energy Statistics 1996, p. 36.

${ }^{55}$ Mike Parker, "Effects on Demand for Fossil Fuels," The British Electricity Privatization Experiment, Privatization: The Record, the Issues, the Lessons, ed. John Surrey (London, England: Earthscan Publications Limited, 1996), p. 120.

${ }^{56}$ Mike Parker, "Effects on the Demand of Fossil Fuels," The British Electricity Privatization Experiment, Privatization: The Record, the Issues, the Lessons, ed. John Surrey (London, England: Earthscan Publications Limited, 1996), pp. 129-130.

${ }^{57}$ Colin Robinson, "Profit, Discovery, Entry: The Case of Electricity," Regulating Utilities: A Time for Change? ed. Colin Robinson (London, England: Institute of Economic Affairs, 1996), p. 116.

${ }^{58}$ Department of Trade and Industry, Digest of the United Kingdom Energy Statistics 1996, p. 156

${ }^{59}$ Organization of Economic Cooperation and Development (OECD), Country Annexes, p. 297.

${ }^{60}$ United Kingdom, Department of Trade and Industry.

${ }^{61}$ Colin Robinson, "Profit, Discovery, Entry: The Case of Electricity," Regulating Utilities: A Time for Change? ed. Colin Robinson (London, England: Institute of Economic Affairs, 1996), p. 115.

${ }^{62}$ Organization of Economic Cooperation and Development, Country Annexes, p. 297.

${ }^{63}$ Mike Parker, "Effects on Demands for Fossil Fuels," The British Electricity Privatization Experiment, Privatization: The Record, the Issues, the Lessons, ed. John Surrey (London, England: Earthscan Publications Limited, 1996), p. 123.

${ }^{64}$ Electricity Association, Electricity Industry Review, 1996, p. 27.

${ }^{65}$ Electricity Association, Electricity Industry Review, 1996, p. 27

${ }^{66}$ Department of Trade and Industry, Digest of United Kingdom Energy Statistics, 1993 and 1995 editions.

${ }^{67}$ Matthew W. White, Paul J. Joskow, and Jerry Hausman, "Power Struggles: Explaining Deregulatory Reforms in Electricity Markets," Brookings Papers on Economic Activity, Washington DC, 1996.

${ }^{68}$ Gordon MacKerron and Isabel-Segarra, "Regulation," The British Electricity Privatization Experiment, Privatization: The Record, the Issues, the Lessons, ed. John Surrey (London, England: Earthscan Publications Limited, 1996), p. 97.

${ }^{69}$ See the 1983 article by Stephen Littlechild and Michael Beesley in "Principles, Problems, and Priorities," Privatization \& Economic Performance, ed. Matthew Bishop, John Kay, and Collin Mayer (New York, Oxford University Press, 1994), pp. 15-31. 
7Tirwin M Stelzer, "Lessons for UK Regulation from Recent U.S. Experience," Regulating Utilities: A Time for Change?, ed. Michael Beesley (London, England: The Institute of Economic Affairs, 1996), p. 196.

${ }^{71}$ In some states, PUC commissioners are selected directly by the electorate.

72،"UK Electricity Privatization: The Regulator Rides Forth," The Financial Times, September 27, 1990.

${ }^{73}$ John Surrey, "Unresolved Issues of Economic Regulation," The British Electricity Privatization Experiment, Privatization: The Record, the Issues, the Lessons, ed. John Surrey (London, England: Earthscan Publications Limited, 1996), p. 235.

74،"Labor Threatens REC Incentives, "Public Utilities Forthrightly, June 15, 1995, p. 37.

75،"Calif. Oks Price Cap Plan for T\&D," Public Utilities Forthrightly, January, 1997, p. 48.

${ }^{76}$ George MacKerron and Jim Watson, "The Winners and Losers So Far," The British Electricity Privatization Experiment, Privatization: The Record, the Issues, the Lessons, ed. John Surrey (London, England: Earthscan Publications Limited, 1996), p. 199.

"Gordon MacKerron and Isabel Boira-Segarra, "Regulation," The British Electricity Privatization Experiment, Privatization: The Record, the Issues, the Lessons, ed. John Surrey (London, England: Earthscan Publications Limited, 1996), p. 104.

${ }^{78}$ According to Rees and Vickers, this presents the following situation: "Where it is irrational for one party to make investments ex ante without some guarantee that the other part will not opportunistically exploit the situation ex post." Ray Rees and John Vickers,."RPI-X Price-cap Regulation," The Regulatory Challenge, ed. Matthew Bishop, John Kay, and Colin Mayer (Oxford University Press, London, 1995), p. 365.

${ }^{79 ،}$ 'Labor Threatens REC Incentives, "Public Utilities Forthrightly, June 15, 1995, p. 37.

${ }^{80}$ "Blair, Keeping Up Pace, Pledges Package of Reforms," New York Times, May 15, 1998, p. 3A. 


\section{Chapter 3}

\section{Electricity Reform and Privatization in Australia}

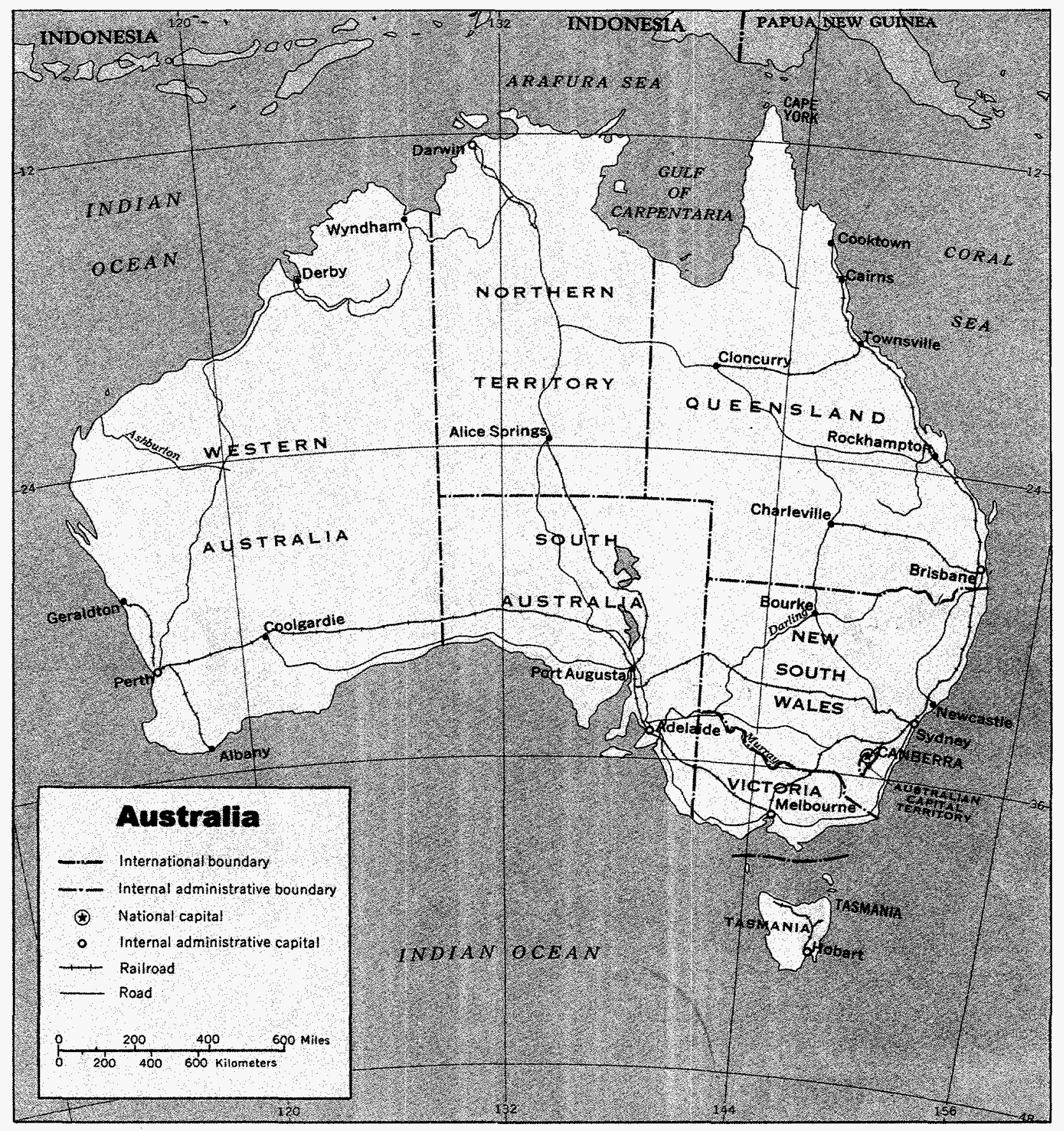





\section{Electricity Reform and Privatization in Australia}

Prior to the reforms of recent years, the supply of electricity in Australia was provided by vertically-integrated, publicly-owned state utilities meeting the needs of individual states and territories. ${ }^{1}$ The electricity industry had never operated on a national basis. Interstate grid connections were weak and electricity trade had been limited between the interconnected states. ${ }^{2}$ The state governments were responsible for operational and planning activities, and tariff structures. The National Commonwealth government's only involvement in the industry was through its principle shareholder status in the Snowy Mountains Hydro-electric Scheme in which the two states of Victoria and New South Wales also hold shares. Some regulatory controls by the Commonwealth were exercised, however-mainly through control over state borrowing limits, taxation, foreign ownership, and environmental regulations. ${ }^{3}$

In 1995; Australia's population of 18 million was roughly one third that of the United Kingdom and half of Argentina's population. Australia's landmass totals almost three million square miles, almost double the size of Argentina and nearly thirty times the size of the United Kingdom. However, the majority of the population is concentrated in three states (New South Wales, Victoria, and Queensland) located in the eastern portion of the country (Table 14). Consequently, these three states account for most of Australia's electricity industry.

Per capita electricity consumption in Australia is roughly ten times that of Argentina and more than twice that of the United Kingdom. In 1995, Australia's electricity generation was 160 million kilowatts per hour (Table 15). Australia's two most populous states-New South Wales and Victoria accounted for 35 percent and 23 percent, respectively, of total domestic electricity consumption (Tables 14 and 15). ${ }^{4}$ Electricity generation was provided primarily through coal-fired power stations, which represented about 80 percent of the total fuel usage. The remaining 20 percent of electricity generation is fueled through a combination of natural gas and hydroelectricity. Nuclear power plants have never been used for electricity generation. ${ }^{5}$

Table 14. Australian Electricity Profile: Consumption By Class of Customer and Population in 1995

\begin{tabular}{|c|c|c|c|c|}
\hline & $\begin{array}{l}\text { Residential } \\
\text { (Billion kWh) }\end{array}$ & $\begin{array}{l}\text { Commercial } \\
\text { (Billion kWh) }\end{array}$ & $\begin{array}{c}\text { Industrial } \\
\text { (Billion kWh) }\end{array}$ & $\begin{array}{l}\text { Population } \\
\text { (Thousands) }\end{array}$ \\
\hline \multicolumn{5}{|l|}{ Australian Capital } \\
\hline New South Wales . . . . . . . & 16.1 & 8.2 & 23.8 & 6,152 \\
\hline Northern Territory ....... & .3 & .9 & - & 177 \\
\hline Tasmania ............. & 1.8 & .7 & 5.6 & 473 \\
\hline Victoria ............. & 15.6 & 7.8 & 15.6 & 4,521 \\
\hline Western Australia & 2.9 & 7.8 & -. & 1,746 \\
\hline
\end{tabular}

Sources: Australian Electricity Supply Industry, Electricity Supply Association of Australia Limited, http://www.ozemail. com.au/ esaamelb/page 2.htm; and Australian Bureau of Statistics, Australia Demographic Statistics, September Quarter 1996 (Canberra, Australia, March 1997), Table 3.

Notes: $\mathrm{kWh}$ (kilowatt-hour) = one watt $\mathrm{x}$ one hour $\times 10^{3}$. The sum of the three consumption sectors will not equal total consumption because other sectors (such as public lighting, traction, and not classified) are not included in this table. For total consumption for each state and territory, see Table 3. 
Table 15. Australian Electricity Consumption, Generation, Imports, and Capacity by State and Territory, 1995

\begin{tabular}{|c|c|c|c|c|}
\hline & $\begin{array}{l}\text { Consumption } \\
\text { (Thousand kWh) }\end{array}$ & $\begin{array}{c}\text { Generation } \\
\text { (Thousand kWh) }\end{array}$ & $\begin{array}{l}\text { Net Imports } \\
\text { (Thousand kWh) }\end{array}$ & $\begin{array}{c}\text { Principal Power } \\
\text { Stations Capacity } \\
\text { (MW) }\end{array}$ \\
\hline \multicolumn{5}{|l|}{ Australian Capital } \\
\hline Territory & 2,272 & -- & 2,272 & -- \\
\hline New South Wales ...... & 49,648 & 54,339 & 4,478 & 12,150 \\
\hline South Australia ..... & 9,257 & 8,157 & 2,420 & 2,407 \\
\hline Tasmania ........... & 8,044 & 8,698 & -- & 2,434 \\
\hline Victoria ............. & 32,843 & 38,174 & $-1,151$ & 7,805 \\
\hline Western Australia . . . . . & 10,772 & 12,177 & -- & 2,638 \\
\hline
\end{tabular}

Note: $\mathrm{kWh}$ (kilowatt hour) = one watt $\mathrm{x}$ one hour $\times 10^{3}$, and MW (megawatt of electricity) = one watt $\times 10^{6}$. Consumption does not always equal generation plus net imports due to transmission losses.

Sources: Australian Electricity Supply Industry, Electricity Supply Association of Australia Limited. <http://www.ozemail.com. au/ esaamelb/page2.htm>.

Unlike the situation in the United Kingdom (UK), electricity reform and privatization in Australia have occurred at both the state and national levels. Although the Australian and U.S. electricity industries are in many ways very different, Australia's dual path to electricity reform bears some similarities to current developments in U.S. electricity markets. One result of Australia's dual state/national approach to electricity reform is that each state has pursued different reforms with reform efforts at the national level providing more guidance than direction. Reform at the state level differs from UK reform, which was entirely a central government effort. These distinctions are noted below. Victoria has pursued the most aggressive electricity reform measures in Australia and has most closely followed the UK model, while other states have pursued various degrees of more limited reform.

At the national level, Australia's electricity reform also differs significantly from the UK model in the operation of the national electricity pool, in the authority of the national electricity regulator, and the level of regional control. In other ways, national reforms have been quite similar to those of the United Kingdom. Australian governments have generally split up their electrical industries along functional lines, with the state of Victoria adopting the UK model's separation of electricity into four segments. A national grid and national pool are currently operating and are expected to be further developed. The new national regulatory regime is to be "light handed" and a form of price regulation (intended to promote efficiency) will be applied to the regulated sectors.

The privatization of energy is a recent, but internationally widespread, trend which has placed greater reliance on market forces and less dependence on government in the allocation of resources. Australia's electricity industry is part of this trend as state government involvement in and ownership of this industry has moved toward corporatization and privatization since 1995 . The "overcapitalized investments ${ }^{\prime \prime 6}$ made by the state governments in the electricity sector (generation capacity, transmission systems, and distribution) had resulted in "high levels of reserve plant margins combined with high debt levels with minimum returns." ${ }^{\prime 7}$ Monetary restraints and debt placed pressures on the federal and state governments to reduce expenditures and increase efficiency while still providing service for the public. ${ }^{8}$

The objective of reform in Australia was to "deliver more efficient and sustainable use of capital infrastructure and energy resources and to improve Australia's domestic and international economic performance. ${ }^{\prime 9}$ To achieve these objectives, the government considered competition the most effective tool. In addition, the state governments estimated that electricity reform would add an estimated $\$ 5.0$ billion annually ${ }^{10}$ to the Australian Gross Domestic Product. ${ }^{11}$ 
The electricity reform effort has been underway since 1991, when the various state and territorial governments agreed to work cooperatively to introduce a competitive electricity market in the southern and eastern regions of Australia. (For a general description of the structure of the Australian government, see the box entitled "The Australian Governmental System.")

At a special conference in November of 1990, the Industry Commission (a federal statutory body whose main objective was to improve the efficiency of the Australian economy) was appointed by the Commonwealth to review the electricity industry and discuss the feasibility of a national electricity grid. The Industry Commission recommended reforms that would eventually lead to the privatization of the electricity market. These reforms included: unbundling the electricity industry into separate generation, transmission, distribution sectors; privatizing and corporatizing the separate (but still stateowned) electricity transmission and distribution sectors; introducing competition into the generation sector; combining the state-owned transmission units into a single national grid; and restricting transmission and distribution businesses to the transport of electricity. In addition, the Industry Commission recommended that after privatization, tariffs should be reflective of actual costs, and cross-subsidies (from urban to rural consumers) should be eliminated.12 Six months later, the Commonwealth, state and territorial heads of government established the National Grid Management Council as an intergovernmental advisory body to develop the National Electricity Code in consultation with industry, stakeholders, and the public. ${ }^{13}$

In October 1994, the National Grid Management Council prepared the first draft of the national electricity market report entitled "Restructuring of the Electricity Supply Industry in Australia." This report addressed the broad objectives for the proposed national electricity market, as well as the different types of trading arrangements to be

\section{The Australian Governmental System}

The Australian political institutions and practices are based on the Western liberal democratic tradition, reflecting institutions in Canada, the United Kingdom and the United States. ${ }^{a}$ Although Australia is an independent nation, like Canada, it retains close constitutional links with Britain and gives allegiance to Queen Elizabeth II of Great Britain and Northern Ireland, who is also formally Queen of Australia. The Queen is represented in Australia by a Governor-General and six state Governors. Under the Federal Constitution, the Governor-General's responsibilities include summoning and terminating Parliament, concurring on Bills, appointing Prime Ministers and judges, setting up Departments of State, and commanding the armed forces.

The Executive (the Cabinet) is the major policy-making agency of the Federal Government and is presided over by the Prime Minister.

The Federal Constitution of Australia describes the powers of the Federal parliament (government). (The division of powers between the Federal and State Parliaments follows the American model of federation.) The Federal government has two chambers: the House of Representatives and the Senate. The House of Representatives membership is almost twice that of the Senate. The House has 148 member representing states and territories. State parliaments (governments) are subject to the provisions of the constitution at the Federal level as well as their own state Constitutions. All state parliaments (governments) except Queensland, which abolished its Senate in 1922, have two chambers. State Governments are responsible for the remaining powers not administered by the Federal Government. The powers of the local government vary from state to state and are derived from legislation enacted by the state government.

The Australian federation has a three-tier system of government and is characterized by the separation of powers to provide checks and balances:

- at the national level (under the provisions of the Constitution) there are three bodies which are responsible for the national interest of the country: the Legislature (the House of Representatives and the Senate), the Executive Government, and the Judiciary;

- at the State and Territory level (under the relevant statutes) a Legislature, Executive Government and Judiciary; all are responsible for matters specifically relevant to the States and Territories;

- there are approximately 900 local government bodies at the city, town, municipal, and shire level.

\footnotetext{
${ }^{a}$ Fact Sheet January 1995-0011:"Australia's System of Government", <http/www/dfat.gov.au/ipb/pubcn/fact_sheets_96/011sysgv.html.
} 
provided, how it would operate, and how its security would be maintained. The report's recommendations were endorsed by each of the state governments and the Australian Capital Territory. In September 1995, the National Grid Management Council prepared a second report that outlined the market functions of the proposed national electricity market. The National Electricity Code (the Code) establishes the rules and procedures for operating in the competitive national electricity market. The Code was completed in September 1996 and was sent to the Australian Competition and Consumer Commission for approval in November $1996 .{ }^{14}$

A further impetus to reform was the release of the 1993 National Competition Policy Review, known as the Hilmer Commission Report. The report identified industries where reform could yield substantial benefits to Australia's economy. Electricity was one of these industries. In April 1995, the Council of Australian Governments agreed to a national competition policy reform, the National Competition Reform Act of 1995, which provides for uniform protection of consumer and business rights and increased competition in all jurisdictions. This policy would also enhance the national economic interest by improving Australia's international competitiveness, as well as encourage competition in the trading activities of government-owned enterprises.

As part of the reform package, the Commonwealth agreed to provide financial assistance payments to the states and territories totaling $\$ 4.2$ billion Australian dollars ${ }^{15}$ in return for the states meeting their agreed obligations, including the reform of their electricity, gas, water, and road transport industries. ${ }^{16}$

\section{Creation of the National Electricity Market}

As specified, the objectives of the competitive national electricity market are:

- unbundling (the separation of transmission, generation, distribution, and marketing activities);

- ensuring non-discriminatory access to the national transmission and distribution system;

- ensuring that customers (including generators, marketèrs, and traders) have a choice of supplier;

- establishing transmission prices that are reflective of actual costs;

- utilizing a merit order dispatch system (i.e., the order in which generators will dispatch their generation in the pool--the lowest bid price will be dispatched first to supply demand):

- providing for interstate trading of generation;

- ensuring non-discriminatory access for new industry participants in generation and marketing; and

- establishing uniform regulation based on an industry code of conduct. ${ }^{17}$

The Australian national electricity market (NEM) is to develop in stages until a fully competitive market for electrical generation and retail supply is achieved by 2001 . Although it is referred to as a national market, NEM will initially include the states of Victoria, New South Wales, South Australia, Queensland, and the Australian Capital Territory, with the possibility of an expansion into Tasmania following its grid interconnection. Western Australia and the Northern Territory will not participate in the market due to geographical and cost factors. Victoria, New South Wales, and the Australian Capital Territory are currently operating in a transitional phase of the national electricity market (NEM1). South Australia will enter the market in 1998 and Queensland is scheduled to connect to the national grid by 2001 . (See the box entitled "The National Electricity Market (NEM) Time Table.")

The first phase of the NEM was scheduled for 1995 (covering New South Wales, Victoria, and the Australian Capital Territory), but the actual startup of phase 1 began on May 5,1997. A national electricity generation pool was introduced when Victoria and New South Wales began an interstate wholesale electricity trading market, with the Australian Capital Territory participating in the linked market through New South Wales. In this market, the states still operate under a separate wholesale power pool but generators compete directly with each other (see the section entitled "National Australian Power Pool" for a discussion on the operation and structure of the new national power pool). When less expensive electricity is available in one state (e.g., Victoria), the pool allows another state (e.g., New South Wales) to import this cheaper electricity. The new power pool is intended to create a national electricity market in Australia.

\section{Transitional Phase: Interstate Connections}

Before the national electricity market can become fully operational in the southern and eastern regions of Australia, three main transmission links need to be built to interconnect these regions to form a national electricity grid. ${ }^{18}$ Currently, the states of New South Wales, Victoria, South Australia, and the Australian Capital Territory (ACT) are connected to form a grid network. However, 


\section{The National Electricity Market (NEM) Time Table}

The different phases of the national electricity market provide a timeframe for the evolution of state and territory electricity markets into the full national electricity market. There are three phases: NEM1 (two stages) ${ }^{\mathrm{a}}$, NEM2, and NEM3.

NEM1 stage 1: On May 5, 1997, the interstate wholesale electricity trading market began between New South Wales, Victoria, and the Australian Capital Territory (Australian Capital Territory is participating in the market via New South Wales. The interstate market operates under each state's existing state code arrangements. In this phase, interstate trading among the states exist but the security of the power system is still the responsibility of the individual states. There are limitations on the amount of power that can be traded between state markets; however, this will be gradually removed.

The NEM1 stage 2 phase will began in October 1997. In this stage, all the regulations of the Code will be enforced (except for market rules and system security, which will continue to be the responsibility of the states until the national electricity market becomes operational).

(The original program for the phased introduction of the NEM included three phases: NEM1, NEM2, and NEM3. However, due to the rapid implementation and development of the national electricity market in the NEM1 phase, it was recognized that NEM2 was no longer necessary.)

NEM3 pilot: Beginning in October 1997, Queensland will participate in the national electricity market. Although Queensland is not connected to the national grid (and does not participate in interstate electricity trade), it will operate its own electricity system based on arrangements specified in the Code. Since the state does not have an existing wholesale power market, it chose to follow the Code's arrangements instead of developing temporal arrangements. (The states' trading arrangements would be nullified once it was interconnected to the national grid).

NEM3: By mid 1998, the national electricity market will be operational and the market arrangements specified by the Code will be applied. South Australian generators will enter the market as full participants.

In the future, NEM may expand to incorporate Tasmania, following grid interconnection.

\footnotetext{
aTransgrid, NEM1: Gateway to the National Electricity Market (Implementation Edition, May 1997), http://www.tg.nsw.gov.au/sem/doc/reports/nem1gateway/(May, 1997).

bohn Landels, "National Electricity Market Developments in Australia," National Grid Management Council (Australia, June 1997).
}

each government grid is not directly connected to the other state grids; instead, they are all linked together via Victoria. The grids of Victoria and New South Wales are linked with a maximum transfer capability of 1,100 megawatts (with the largest capacity transmission network running through the Snowy Mountains Hydroelectric Scheme). Victoria and South Australia are linked with a total transfer capability of 500 megawatts. ${ }^{19}$ The ACT does not generate electricity; it imports its electricity from New South Wales. In 1995, interstate flows of electricity represented on average less than 2 percent of total electricity consumed within the states mentioned above (excluding ACT).

The three main links that must be built to interconnect the southern and eastern regions of Australia to form a national grid are (1) New South Wales and South Australia, (2) New South Wales and Queensland, and (3) a sub-sea link between Victoria and Tasmania with a 300megawatt interconnection after the year 2000 .
In 1993, a feasibility study to evaluate the economic and environmental implications of the Victoria to Tasmania sub-sea link was both initiated and completed. In 1996, similar feasibility studies were initiated for the other two necessary grid links. In 1997, New South Wales and Queensland announced their intentions to build the actual link interconnecting their two states by $2001 .{ }^{20}$ As of early 1997, the remaining feasibility study was still in progress. $^{21}$

The introduction of a national electricity market will change the structure, operation, and regulations of the traditional Australian electricity industry. The expected changes include:

- separation of the vertically-integrated, state-owned electricity monopolies into four activitiesgeneration, transmission, distribution, and marketing-with competition being allowed for generation and marketing activities. 
- regulation of the wholesale power generation market; transmission networks will be transferred from the states to the national government. ${ }^{22}$ Since the transmission sector will retain monopoly charateristics, the prices charged to customers for the connection and use of the system will be listed separately. In addition, network prices will be costreflective, and non-discriminatory to new entrants entering the market.

- introduction of competition into the individual state electricity distribution systems (the existing distribution companies will now have a marketing function).

\section{Implementation-The National Electricity Code}

The National Electricity Code ("the Code") establishes the regulatory and operational framework of the new Australian national electricity market and binds all participants in the wholesale power generation market to the specified rules. ${ }^{23}$

The Code addresses the following: market rules; grid connection and access; metering; network pricing (transmission and distribution); and system security and procedures for Code administration. The Code also contains a chapter on transitional matters which specifies permissible short-term deviations from the Code and the transitional paths that will be adopted by the participating state jurisdictions to reach conformity by the end of the transition phase. The Code is not legislation enacted by the Australian national government. However, it is binding on all market participants. In addition, the Code also outlines the objectives, roles, and functions of two new national regulatory bodies, the National Electricity Market Management Company (NEMMCO) and the National Electricity Code Administrator Limited. (See the box entitled "The Regulators.") These bodies were established by the participants of the national electricity market (state and territory governments). The Code must be submitted to the Australian Competition and Consumer Commission (ACCC) for approval before it can be implemented. In addition, changes in the Code can be made only with the approval of the ACCC. In November 1996, the Code was submitted to the ACCC, with approval expected in late $1997 .{ }^{24}$

There are four groups who will participate in the wholesale power generation market. These groups are required to become participant members of the National Electricity Code Administrator Limited and are subject to all the Code rules. The first group is comprised of market participants (contestable customers, generators, marketers, and brokers). Initially, only contestable customers-a consumer with an annual electricity consumption of at least 10 megawatts - will be eligible to participate in the market. However, as the market matures, all customers will eventually have the option to participate because eligibility requirements will be reduced. All generators with a net export in excess of 30 megawatts are required to participate in the wholesale power generation market. ${ }^{25}$ Smaller generators can also participate on a voluntary basis. The other three groups are NEMMCO, network service providers (transmission and distribution), and regional system operators (Figure 9).

\section{Buying Electricity in the National Market}

The national electricity market will offer a range of options to suit the specific needs of electricity buyers and sellers. Contestable customers have two options: (1) participate in the wholesale market, or (2) participate in the retail market. If the contestable customer decides to participate in the retail market, all of their electricity will be supplied through a marketer and they can not participate in the wholesale market. On the other hand, if the contestable customer chooses to trade in the wholesale market they must register as a participant with the NEMMCO.

Wholesale Trading Market. In the wholesale trading market there will be three levels of trading: via a longterm bilateral contract; via a short-term forward market; and via a spot trading market. (For further explanation of the trading market, see the box entitled "Trading Arrangements.") Participants in the wholesale market can operate in any combination of these markets. All wholesale electricity trading will be accounted for through the pool. For example, electricity provided to the network from wholesale suppliers (generators) and electricity taken from the network by contestable customers and marketers will be recorded. Marketers will participate in the wholesale market on behalf of those contestable customers who have made a decision not to participate in the wholesale market or who have not met the megawatt eligibility requirements to participate in the wholesale market. In the wholesale environment, electricity buyers could be both end-use customers as well as marketers. Sellers of electricity could be generators as well as marketers.

Although each form of trading operates independently, the operations and results in each trading market affect the others. For example, when a contestable customer has a long-term contract with a generator, it can operate its business in a secure environment knowing that their costs 


\section{The Regulators}

The National Electricity Code Administrator Limited

As the administrator of the Code, the National Electricity Code Administrator Limited (NECA) will monitor and report on compliance with the Code; enforce the Code; resolve disputes through the Code; and manage changes to the Code.

\section{National Electricity Market Management Company}

The National Electricity Market Management Company (NEMMCO) will be responsible for the management and administration of the national electricity market across participating jurisdictions. It is also responsible for national merit order, and spot and forward trading markets. In addition, the NEMMCO will be responsible for the operational integrity of the power pool in terms of achieving an equilibrium between supply and demand.

\section{Australian Competition and Consumer Commission (ACCC)}

The ACCC is a Commonwealth agency responsible for applying and administering Australia's national competition law (the national anti-trust laws). The Code must be approved by the ACCC before it can be implemented. Before the ACCC approves the Code it must be satisfied that the Code's rules will result in a net benefit to the public and are not anti-competitive. The ACCC will have a continuous oversight role in ensuring that the Code promotes competition and delivers public benefit.

Figure 9. Australian National Electricity Market

\section{National Electricity Market}

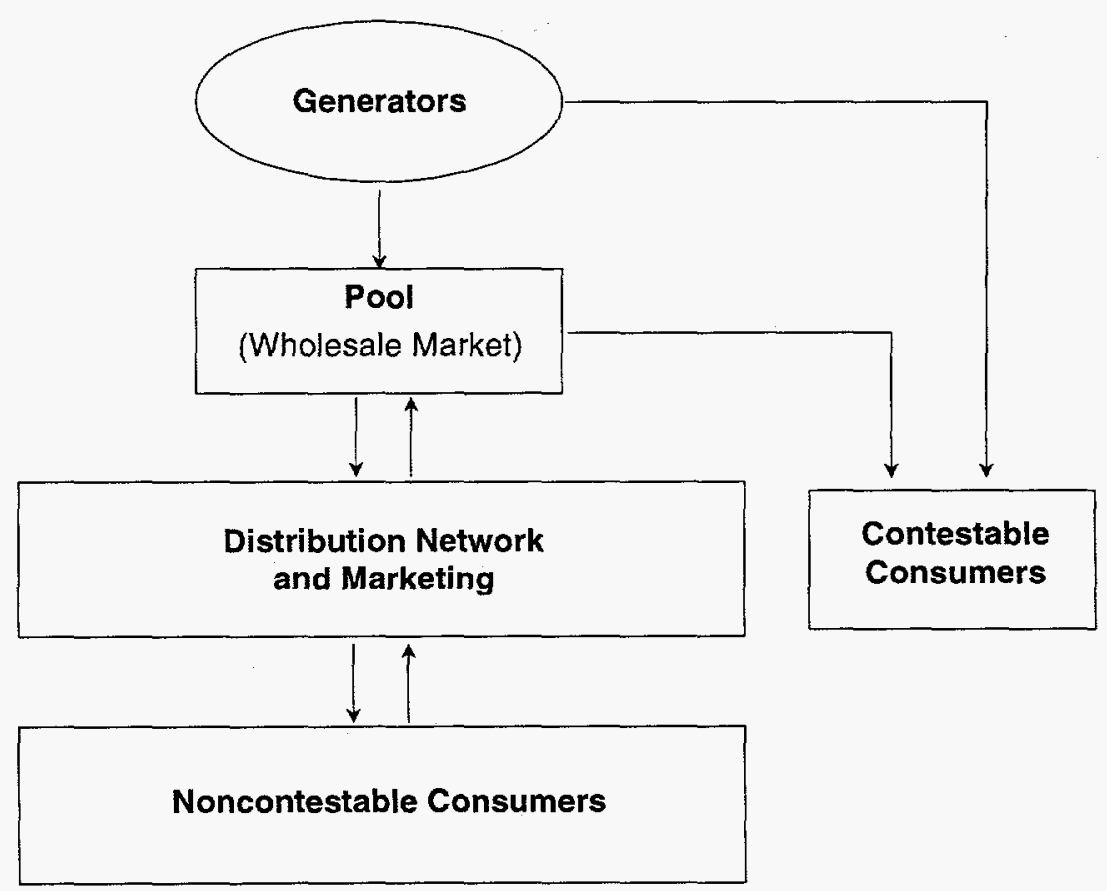

Source: International Energy Agency, Energy Politics of IEA Countries, 1997. 


\section{Trading Arrangements}

\section{Long Term Trading}

- A long-term bilateral contract market - is a market where contestable customers, marketers, and generators have the choice of entering into contractual arrangements. These contracts typically cover long-term commitments between buyers and sellers of electricity and have a fixed volume of electricity over a specified time period. Contractual agreements are purely financial trading instruments and will not have an impact on pool trading. The bulk of electricity generated in Australia may be covered by this type of contract, particularly for those contestable customers who do wish to operate in the pool--a highrisk environment.

\section{Short Term Forward Trading}

- A short-term forward trading market - is a secondany market where participants (both generators and contestable customers) can trade contracts, one to two days ahead of actual dispatch, thus allowing the contestable customer to adjust his generation demand on the basis of short-term planning commitments in his business. It also allows the contestable customer to better manage risk by not participating in the spot market. In addition, this type of trading allows generators to better manage risks associated with earlier generation commitment decisions.

\section{Spot Trading}

- A spot trading market - is a market where the supply and demand of electricity is balanced at any point in time--at half hour intervals. (Because electricity cannot be stored, equilibrium in this market must be achieved.) In general, at this half-hour interval, the spot price is created, reflecting the actual market conditions that exist at that particular time. More specifically, the spot price is based on a merit order dispatch system where the spot price is calculated after the last selected generator in that half- hour interval has dispatched his last unit of power generation. This type of market can be beneficial to the contestable customers because it allows them to trade on the basis of their actual generation or demand needs. This type of trading is likely to be marginal in Australia because of the high risks associated with this trading market. When the national electricity market has fully evolved (expected in mid 1998), the Australian National Electricity Market Management Company (NEMMCO) will operate the spot trading market (often referred to as "the pool").

are fixed for electricity generation. In addition, long-term contracting provides the foundation for contestable customers to make long-term plans. On the other hand, short-term forward trading allows the contestable customer to make changes to its contract coverage one or two days before actual trading begins, in turn, giving the customer the flexibility of purchasing more electricity at less expensive prices. Spot trading is a vehicle that is used to balance supply and demand in half-hour increments (in Australia) and establish the price of electricity at that specific time. ${ }^{26}$

Retail Trading-Opting Out Of The Pool. In addition to the wholesale trading arrangements described above, contestable customers have the choice to purchase electricity under a retail contract and thereby forfeit the opportunity to participate in the pool (perhaps due to risk). Under retail trading, the buyer and seller can enter into any type of contractual arrangement and are not bound to restrictions like those of the wholesale trading market. Customers have the opportunity to negotiate competitive contracts with the marketer of their choice, thereby adding competitive pressure on suppliers for better service and lower prices. In a typical contract, the marketer would pay for the customer's electricity usage and network charges and, in turn, would charge the customer for these services. Prices for network service payments and energy payments would be unbundled in the bill. These charges would look similar to traditional tariff arrangements; however, the payment under the retail contract would reflect competitively-determined prices. $^{27}$

\section{Electricity Reform at the State and Territory Levels}

Since low-cost coal is relatively abundant, total generating capacity in the Australian electricity industry is dominated by large coal-fired power stations. Even though fuel usage varies from state to state (depending on the availability of natural energy resources), coal is the dominant fuel source, accounting for 80 percent of primary energy consumption (Table 16). The state of Tasmania is the exception, where electricity generation is mostly fueled through hydroelectric power.

In the past, electricity generation in Australia was developed independently by the individual states on a need basis (the Australian Capital Territory, however, does not 
Table 16. Australian Electricity Generation Fuel Usage in 1994

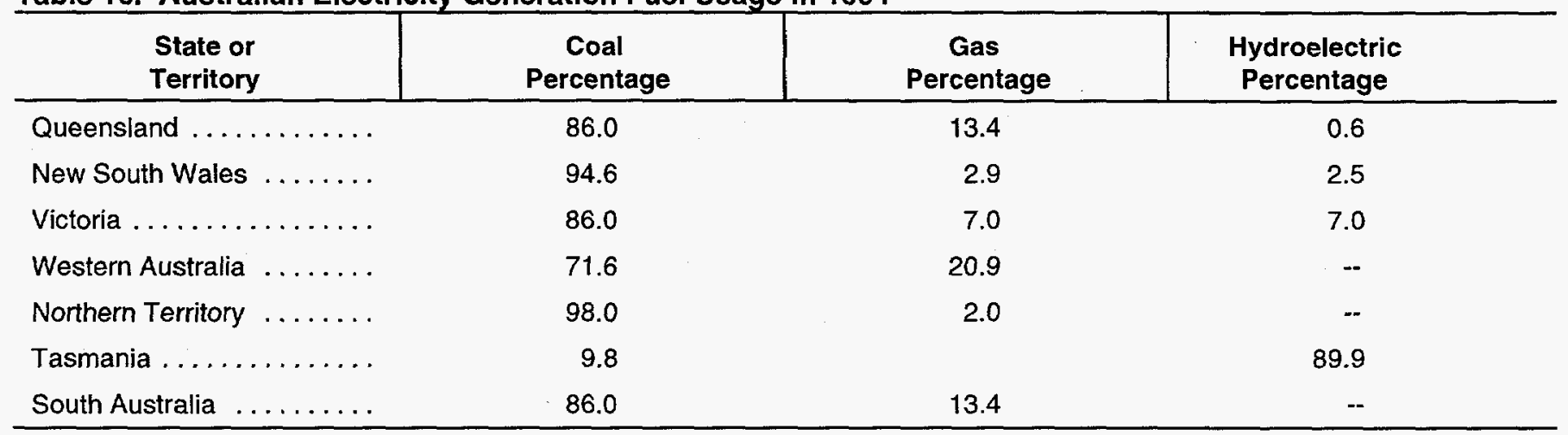

Source: "State Poll May Delay Power Industry Reform," The Australian (February 9, 1995) p. 4. Australian Electricity Supply Industry, Electricity Supply Association of Australia Limited. < http://www.ozemail.com.au/ esaamelb/page2.htm>.

generate its own electricity). Total generation capacity varies among individual states and territories. For example, the states of Victoria, New South Wales, and Queensland account for a substantial majority of Australia's total electricity consumption. However, in the national electricity market, states will no longer supply electricity to customers directly in their respective states, but will participate in the national power pool. (See the section entitled "Creation of the National Electricity Market.")

The Australian electricity industry has implemented significant reforms in preparation for their eventual entry into the national electricity market. Although some states will not participate in the market, they have implemented reforms where possible to gain efficiencies to supply customers and generators. Each state government has made different arrangements (and adopted different time schedules) for separating the segments of their electricity industries for entrance into the national competitive market. The state of Victoria is the first and most advanced in its reform in the electricity sector compared to reform in the other states and the single territory (the Australian Capital Territory) that are participating in the national electricity market.

\section{Victoria}

In October 1993, the state of Victoria began its reform with the separation of the electricity system. The State Electricity Commission of Victoria was vertically separated into three segments: generation, distribution, and transmission. In 1994, only a year later, Victoria restructured its state-owned electricity industry further with the intention of privatizing it (Figure 10). The generation sector was divided into 5 companies, and the Victorian Power Exchange was established to operate the wholesale power generation market. The former 29 electricity distribution companies were restructured into 5 companies. ${ }^{28}$ The transmission sector was divided into two components: PowerNet Victoria owns the high voltage transmission grid network and was made responsible for its maintenance; and the Victorian Power Exchange was made responsible for pool operations and system dispatch. In addition, the Office of the Regulator General was created to promote competition in the generation and marketing sectors; to maintain an efficient and economic system; and to protect the rights of customers. ${ }^{29}$

Victoria permitted each of the five distribution companies to retain monopoly rights to supply power to customers in their respective geographic regions. However, in 1996 (in an attempt to introduce competition into what was still a state-owned system), large users (the contestable customers) were free to purchase electricity from any of the five distribution companies. The current monopolies that the five distribution companies have to supply electricity to noncontestable customers will be phased out by December 2000. In December 2000, all customers in Victoria will be contestable. ${ }^{30}$

In 1995, Victoria began the privatization of its electricity assets (Table 17). Since launching its privatization program, the state has generated almost $\$ 16$ billion in revenue, an amount which is mostly being used to repay state government debt.

Through the auction process, Victoria sold off all of its five electric power distribution companies (United Energy, Solaris Power, Eastern Energy, Powercor, and Citipower) in 1995 (Table 17). Companies from the United States, and their consortia, led the way in purchasing these plants.

Victoria pursued a markedly different approach to privatizing its electricity industry than that undertaken in 
Figure 10. Victoria's Wholesale Electricity Market

Electricity Generation and Transmission

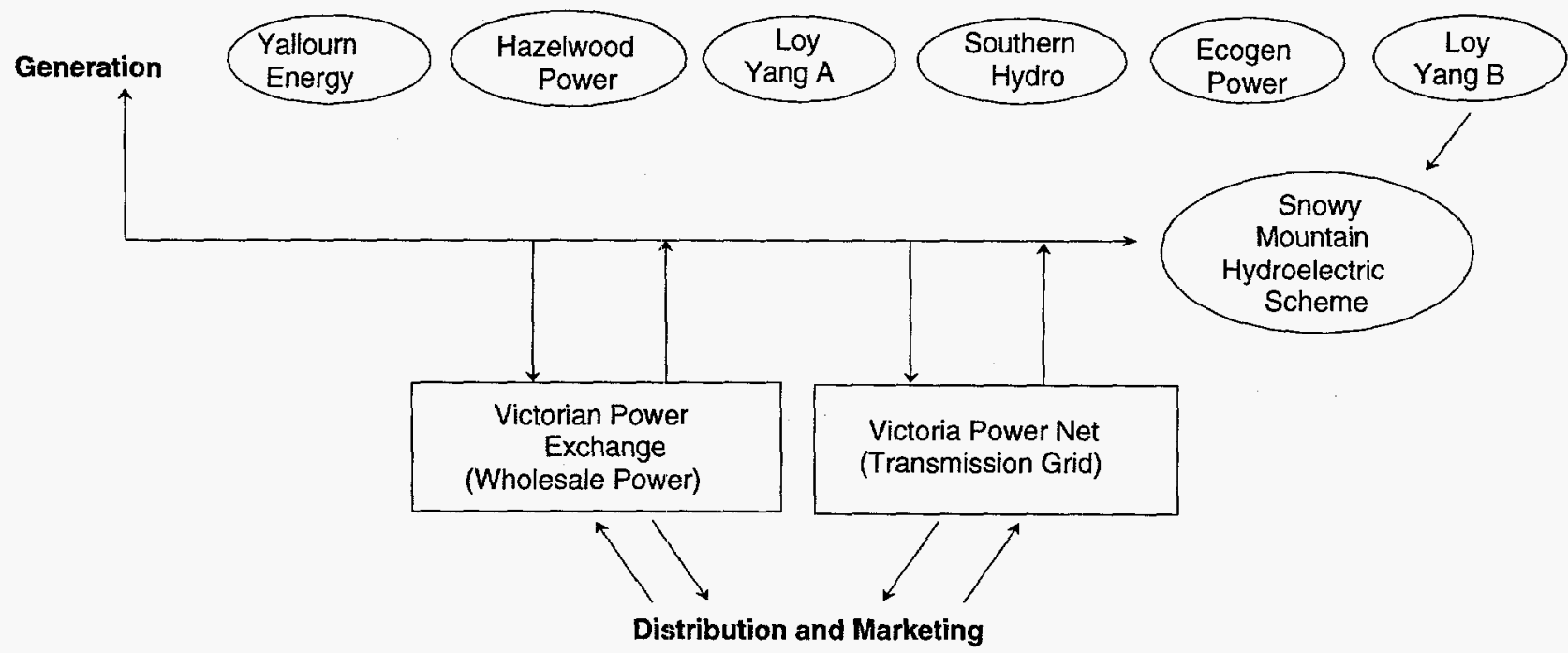

Source: ABARE Economics, Commonwealth of Australia, Australian Commodities, Forecasts, and Issues, September Quarter 1995.

Table 17. Australian Electric Utility Privatization-Related Mergers and Acquisitions (U.S. Dollars)

\begin{tabular}{|c|c|c|}
\hline Australian Electricity Assets & $\begin{array}{l}\text { Acquirer/Merger Partner } \\
\text { (Nationality) }\end{array}$ & Value \\
\hline \multicolumn{3}{|l|}{ Regional Generation Companies } \\
\hline 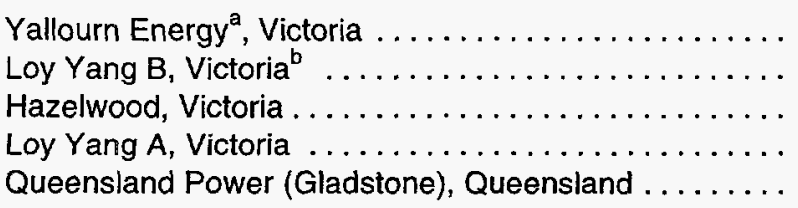 & $\begin{array}{l}\text { PowerGen (UK) } \\
\text { Edison International (U.S.) } \\
\text { National Power (UK)) } \\
\text { GMS Energy (U.S.) } \\
\text { Northern States Power (U.S.) }\end{array}$ & $\begin{array}{l}\$ 1.8 \text { billion } \\
\$ 2.4 \text { billion } \\
\$ 1.9 \text { billion } \\
\$ 3.7 \text { billion } \\
\$ 1.7 \text { billion }\end{array}$ \\
\hline \multicolumn{3}{|l|}{ Regional Distribution Companies } \\
\hline 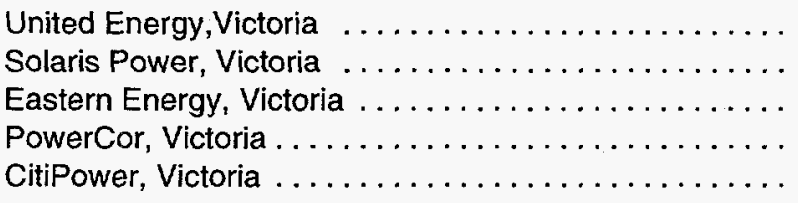 & $\begin{array}{l}\text { Utilicorp United (U.S.) } \\
\text { Energy Initiatives (GPU/U.S) } \\
\text { Texas Utilities (U.S.) } \\
\text { PacifiCorp (U.S.) } \\
\text { Entergy (U.S.) }\end{array}$ & $\begin{array}{l}\$ 1.2 \text { billion } \\
\$ 823 \text { million } \\
\$ 2.1 \text { billion } \\
\$ 1.6 \text { billion } \\
\$ 1.2 \text { billion }\end{array}$ \\
\hline \multicolumn{3}{|l|}{ Transmission Companies } \\
\hline $\begin{array}{l}\text { Queensland Pipelines } \ldots \ldots \ldots \ldots \ldots \ldots \ldots \ldots \ldots \ldots \\
\text { Moomba Sydney Pipeline } \ldots \ldots \ldots \ldots \ldots \ldots \ldots \ldots\end{array}$ & $\begin{array}{l}\text { PG\&E (U.S.) } \\
\text { Nova Corp (Canada) Petronas } \\
\text { (Malaysia) }\end{array}$ & $\begin{array}{l}\$ 128 \text { million } \\
\$ 262 \text { million }\end{array}$ \\
\hline
\end{tabular}

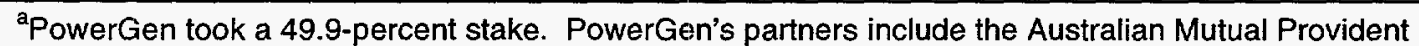
Society (26 percent), the New South Wales State SuperCorp. ( 8 percent), Hastings Funds Management (5.7 percent), and ltochu, a Japanese trading house (10.4 percent).

In 1992 Victoria sold a 51-percent interest in the power plant for $\$ 2.4$ billion and later sold the remainder of the plant in 1997 for $\$ 66$ million.

'Utilicorp holds a 49.9-percent ownership interest. Other investors were Australian companies, AMP Investments (40 percent), and State Superannuation Investment and Management Corporation (9.23 percent). Utilicorp's direct investment was \$258 million.

${ }^{d}$ Energy Initiatives is a subsidiary of General Public Utilities. Energy Initiatives' partner is the Australian Gas Light Company.

Source: Power Asia, various issues, 1996-1997. 
the United Kingdom. In contrast to the United Kingdom (where electricity assets were sold at prices set by the national government), Victoria conducted a series of staggered auctions of its five electricity distribution companies and its four generation companies being privatized. Furthermore, all of the distribution and generation companies were sold intact, and to other companies or consortia of companies. No restrictions were placed on foreign investors.

In the end, all of the newly-privatized Victorian electricity companies were, at least in part, purchased by U.S. and UK utilities. As a consequence, corporate control over these companies was concentrated in no more than a handful of companies, unlike in the United Kingdom where, at least initially, the new shareholders were exclusively portfolio investors. In all cases a premium was paid for shares in the newly-privatized Victorian electric companies. The Victorian treasury benefited fully from these premiums.

Interestingly, the pattern of the disposal of Victoria's electricity assets bears some resemblance to current electric utility restructurings in the United States. A case in point is the recently announced intention of New England Power (a wholly-owned subsidiary of New England Electric) to sell its electricity generation units intact to Pacific Gas and Electric. Apparently, maximum value was achieved via a transfer of corporate control to Pacific Gas and Electric. The divestiture could have been undertaken via a leveraged buyout, or via the creation of a new generation company and a distribution of shares in this company to New England Electric shareholders.

The first distribution company to be sold (United Energy) was purchased by UtiliCorp United (a U.S. company), and its Australian partners ${ }^{31}$ for $\$ 1.2$ billion. ${ }^{32}$ Initial bidders on the plant were Pacific Gas and Electric, (a U.S. utility), the French government-owned Electricite de France, and Scottish Power (a United Kingdom company). However, the latter two withdrew from the bidding process. ${ }^{33}$ The second distribution company, Solaris Power, was sold to Energy Initiatives (a subsidiary of General Public Utilities, a U.S. company) and the Australian Gas Light Company for $\$ 713$ million $^{34}$ plus an additional $\$ 110$ million in franchise fees. ${ }^{35}$ Texas Utilities (a U.S. company) purchased Eastern Energy for $\$ 1.6$ billion in November 1995. Two other groups (Pacific Gas and Electric and PacifiCorp, both U.S. companies), as well an Australian consortium bid on the plant. In November 1995, PacifiCorp won the bid for Powercor for $\$ 1.6$ billion. ${ }^{36}$ The fifth distribution company, Citipower, was sold in January 1996 to Entergy (a U.S. company) for $\$ 1.2$ billion. ${ }^{37}$

Between late 1992 and 1997, Victoria sold its four electric power generating plants (Table 17). In December 1992,
Victoria began its private sector involvement in the generation sector with the 51-percent sale of its Loy Yang B power station to the U.S.-based Edison International's Mission Energy Company for $\$ 2.4$ billion, with the agreement that the government would purchase the station's electricity over the life of the plant. Almost five years later, in May of 1997, Edison Mission Energy purchased the remaining stake in the Loy Yang B power station for $\$ 66$ million- thus terminating Victoria's take-or-pay contract with the company. The termination of this contract has enabled Victoria to further reduce its future state debt. ${ }^{38}$

A second generation company, Yallourn-W, was sold in March 1996 to PowerGen PLC (of the United Kingdom) for $\$ 1.8$ billion. $^{39}$ PowerGen PLC outbid several U.S. companies. ${ }^{40}$ In August 1996, the Victorian government sold the Hazelwood coal-fired plant and coal mine for $\$ 1.9$ billion to a group led by National Power PLC of the United Kingdom. National Power PLC purchased a 51.9percent interest. Others in the consortium included U.S.based PacifiCorp (a 19.9-percent interest), U.S.-based Destec (a 20-percent interest), and the Commonwealth Bank Group of Australia (an 8.2-percent interest). ${ }^{41}$

In May 1997, Victoria sold another power plant (the Loy Yang A coal-fired power station) and a coal mine. This was the largest energy asset privatization in Australian history. The Loy Yang A has the largest coal mine in Australia and is the lowest-cost electricity generator in Victoria, comprising 35 percent of the state's electric supply. ${ }^{42}$ A group led by the U.S. company CMS Energy (50-percent interest) won the bid in May 1997 for \$3.7 billion. Other partners in the consortium were NRG Energy (a subsidiary of Northern States Power of the United States) and Horizon Energy Australia, which each purchased a 25-percent interest. ${ }^{43}$ Other assets in Victoria scheduled for privatization include the Newport and Jeeralang gas-fired power plants, and Victoria's 29percent interest in the Snowy Mountains Hydro-electric Scheme. ${ }^{44}$ PowerNet Victoria Transmission, the owner of the state's high-voltage electricity transmission grid, is expected to be sold in late $1997 .{ }^{45}$

Victoria also announced that it will privatize its stateowned gas utility. The utility will be separated into two or three distribution businesses and its retail sector will be divided into two or five businesses. The state's gas pipelines, Gas Transmission Company, will be sold as a single company.

\section{New South Wales}

In contrast to Victoria, New South Wales (the most populous of the Australian states (Table 14)) has not privatized its electricity industry. Instead, it unbundled the industry 
into corporatized state-owned entities. Reforms in New South Wales have focused on the separation of the Electricity Commission of New South Wales' generation and transmission corporations. In August 1991, the Electricity Commission of New South Wales was renamed Pacific Power and was restructured internally into six smaller business units. Pacific Power's total generating capacity is 11,512 megawatts, excluding the Snowy Mountains Hydro-electric Scheme's generation, and contributes 32 percent to Australia's generation capacity. In 1994, Pacific Power's electricity transmission network business unit was established as a separate legal entity. The Electricity Transmission Authority was separated from Pacific Power in February 1995 and was formed as a separate state-owned corporation now called Trans Grid (Figure 11). The management, operation, and maintenance of the state's high voltage transmission grid is the responsibility of TransGrid. ${ }^{46}$ In October: 1995, the previous 25 distribution boards were aggregated into six businesses and were later corporatized in March 1996 (Table 18).

The New South Wales interim wholesale market began in March 1996 and became fully operational in May 1996. The market is regulated by the Independent Pricing and
Regulatory Tribunal, and Transgrid operates the state's power pool. ${ }^{47}$ In July 1997, customers with energy consumption of 750 megawatts per year became eligible to choose their electricity marketer. This eligibility requirement brings the state in line with Victoria's eligibility requirements, which have existed since 1996.

The state government initially declared it would not privatize its electricity assets to compete in the national market but would continue to maintain ownership of electricity assets. However, in May 1997, the New South Wales treasurer, Michael Egan, recanted this decision and announced his intentions to privatize all of the state's electricity assets. This new decision is expected to face opposition within the state's ruling Labor Party as well as in the labor unions.

The proposed privatization would generate an estimated $\$ 22$ billion dollars in revenue, ${ }^{48}$ which would be used to retire government debt. ${ }^{49}$ All of the assets would be auctioned off without restrictions-excluding Pacific Power, which would be sold with a retained Australian majority ownership interest. ${ }^{50}$ So far, only three privately-owned projects have been initiated. In December 1995, Sithe Energies (a U.S.-based independent power producer

Figure 11. New South Wales' Wholesale Electricity Market

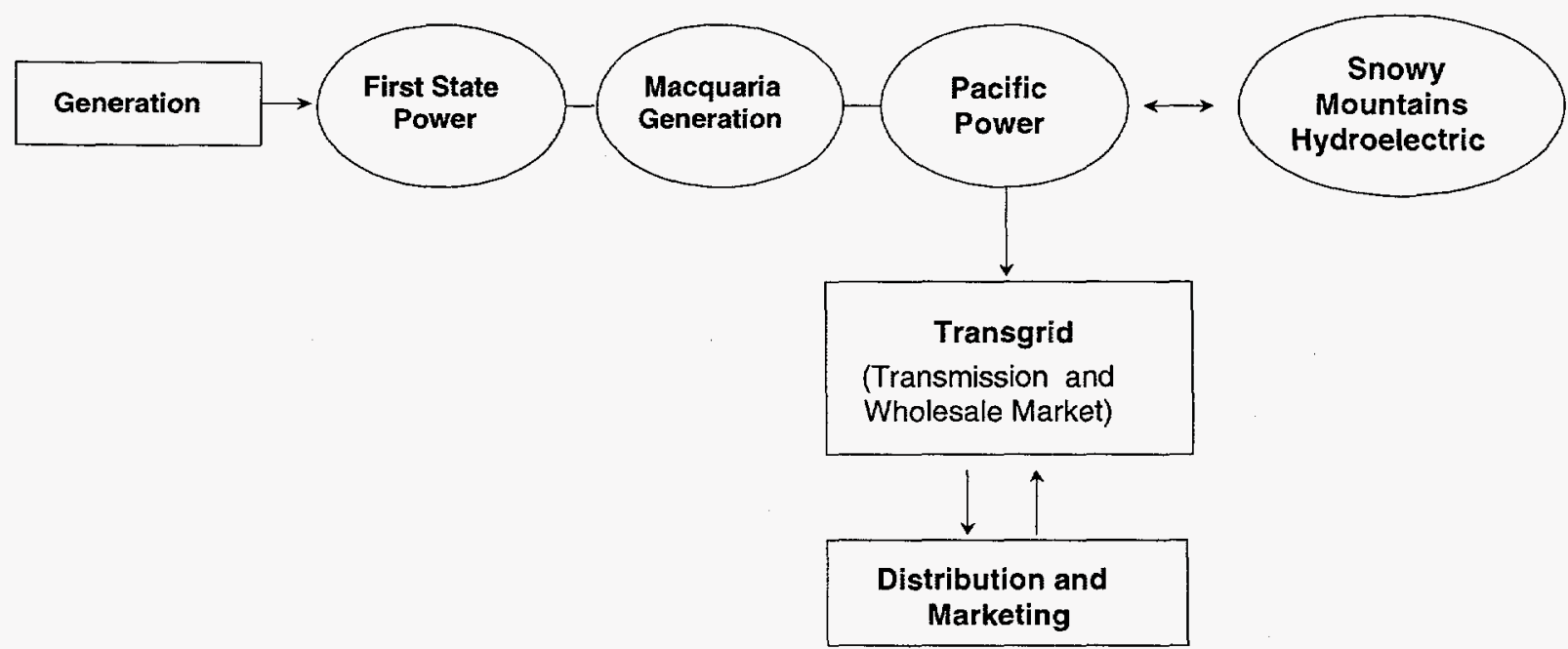

Source: ABARE Economics, Commonwealth of Australia, Australian Commodities, Forecasts, and Issues, September Quarter 1995. 
Table 18. The Australian Electricity Supply Industry Infrastructure Operators

\begin{tabular}{|c|c|c|c|}
\hline State/Territory & Generation Companies & Transmission Companies & Distribution Companies \\
\hline Victoria & $\begin{array}{l}\text { Yallourn Energy* } \\
\text { Hazelwood Power Corp.* } \\
\text { Loy Yang Power } A^{*} \\
\text { Southern Hydro } \\
\text { Ecogen Power } \\
\text { Loy Yang B* }\end{array}$ & PowerNet Victoria & $\begin{array}{l}\text { Eastern Energy* } \\
\text { Solaris Power* } \\
\text { United Energy* } \\
\text { Powercorp* } \\
\text { CitiPower* }\end{array}$ \\
\hline New South Wales & $\begin{array}{l}\text { First State Power } \\
\text { Macquarie Generation } \\
\text { Pacific Power }\end{array}$ & TransGrid & $\begin{array}{l}\text { Energy Australia } \\
\text { Integral Energy } \\
\text { North Power Energy } \\
\text { Advance Energy } \\
\text { Energy South } \\
\text { Far West Energy }\end{array}$ \\
\hline Queensland & $\begin{array}{l}\text { AUSTA Electric } \\
\text { Gladstone* }\end{array}$ & $\begin{array}{l}\text { Queensland Transmission and Supply } \\
\text { Powerlink Queensland }\end{array}$ & $\begin{array}{l}\text { Queensland Transmission and } \\
\text { Supply Corporation } \\
\text { Capricornia Electricity } \\
\text { Far North Queensland Electricity } \\
\text { Mackay Electricity } \\
\text { North Queensland Electricity } \\
\text { South East Queensland } \\
\text { South West Queensland } \\
\text { Wide Bay-Burnett Electricity }\end{array}$ \\
\hline South Australia & ETSA Corporation & ETSA Corporation & ETSA Corporation \\
\hline Tasmania & Hydro-electric Commission & Hydro-electric Commission & Hydro-electric Commission \\
\hline Western Australia & Western Power Corporation & Western Power Corporation & Western Power Corporation \\
\hline Australian Capital Territory & --- & -- & ACTEW Corporation \\
\hline Northern Territory & Power and Water Authority & Power and Water Authority & Power and Water Authority \\
\hline $\begin{array}{l}\text { Snowy Mountains Hydro- } \\
\text { Electric Scheme }\end{array}$ & $\begin{array}{l}\text { Owned by New South Wales, Victoria, } \\
\text { and the Commonwealth Government }\end{array}$ & - & -- \\
\hline
\end{tabular}

*Denotes assets are privately owned. The states of Victoria and New South Wales are the only two that have privatizated some of their electricity assets.

Source: Robin D6avey, APEC Electricity Regulator's Form, Summary Submission (Australia, July 1996), pp. 14-19. 
which is 29-percent owned by the Japanese company Marubeni) and Broken Hill Proprietary (Australianowned) began the construction of a 175-megawatt cogeneration plant at Smithfield (near Sydney, Australia), ${ }^{51}$ with commercial operations to begin in $1997 . .^{52}$ Energy Developments Limited is involved in a small-scale (4megawatt) gas-fired power generation plant, and a proposed 90 -megawatt coal steam methane power plant. ${ }^{53}$

A consortium consisting of Air Liquide Australia Ltd, Itochu Corporation (a Japanese company), and Energy Australia (New South Wales' electricity distributor) was formed in 1995 to develop a 350-megawatt cogeneration plant in Sydney. However, Energy Australia announced in 1997 that it would sell its interest in the project, citing that the company's long-term strategic objectives have changed due to its experience with the first stages of deregulation in the national electricity market. The company's 20-percent interest in the project will be sold to Itochu Corporation. ${ }^{54}$

\section{Australian Capital Territory}

The Australian Capital Territory (ACT) consists of Canberra and a number of surrounding areas. The ACT corporatized ${ }^{55}$ its combined electricity and water utility company in July 1995 (Table 18). This process included separating electricity regulation from the water regulatory function. The ACT does not generate its own electricity and must rely on imports from New South Wales and the Snowy Mountains Hydro-electric Scheme. In March 1996, the ACT began to participate in New South Wales' electricity market. In May 1997, the ACT began to operate in the national electricity market in conjunction with $\mathrm{New}$ South Wales and Victoria and will begin competition in electricity marketing in late $1997 .{ }^{56}$

\section{Queensland}

In January 1995, the Queensland Electricity Commission was restructured and corporatized to form two new government corporations-AUSTA Electric and the Queensland Transmission and Supply Corporation (QTSC). AUSTA Electric is responsible for electricity generation and QTSC is responsible for retail supply, distribution, and transmission. The QTSC has eight subsidiaries: the transmission section of the former Queensland Electricity Commission (Powerlink) and seven regional corporations in charge of distribution and marketing (Table 18). ${ }^{57}$

To further its commitment to the competitive national electricity market, the Queensland government plans to transform its monopolistic electricity industry into a competitive market by the end of 1997. AUSTA Electric has been split into three generating companies that will compete amongst themselves to supply the seven existing government electricity distributors. In addition, three new electricity marketing corporations will be created with operations to begin in July 1997. Currently, there is no physical electricity grid link between Queensland and the southern states; however, Queensland and New South Wales have announced that they will proceed with an interconnection between the two states by $2001 .^{58}$

Queensland began the privatization of its generation sector with the 37-percent equity sale of its Gladstone power station to a consortium led by Comalco (an Australian company) and Northern States Power (a U.S. company). Although there are no further plans to privatize electricity assets, the government will no longer control either electricity prices or AUSTA Electric's investments. ${ }^{59}$ The Broken Hill Proprietary Company (an Australian company) began construction of a 105-megawatt gas-fired power station in 1994. ${ }^{60}$ By 1997, 30 percent of Queensland's generating capacity was owned by the private sector; that proportion is expected to increase as new power stations are constructed to meet expected electricity demand from 1998 through 2006. ${ }^{61}$ Energy Equity (an Australian company) has announced plans to build a gas- fired facility at Barcaldine. Australia Shell has started a feasibility study for the construction of a power station in Callide, Queensland. ${ }^{62}$ Also in 1996, Pacific Gas \& Electric (a U.S. company) purchased Queensland's natural gas pipeline. AUSTA Electric is also considering additional supply options for new generating capacity. Proposals for the 1998-to-1999 time period include the recommissioning of the Collinsville and Callide-A plants; grid interconnection with the New South Wales transmission link; and construction of a 440-megawatt plant between the years 2000 to 2002 . In the years 2003 to 2006 , the state plans to build a power plant with generating capacity between 600 and 1,400 megawatts. ${ }^{63}$

\section{South Australia}

South Australia accounts for 5.1 percent of Australia's total generating capacity (Table 15). In 1995, the vertically-integrated state-owned utility, Electricity Trust of South Australia, was restructured and corporatized as ETSA Corporation (Table 18). The corporation has four subsidiaries: ETSA Generation, responsible for generation; ETSA Transmission, responsible for transmission, system control, and system planning; ETSA Power, in charge of distribution and marketing; and ETSA Energy, responsible for gas trading. ${ }^{64}$ In January 1997, ETSA Generation was separated from its parent company and became an independent government business (ETSA Generation was formerly a subsidiary of ETSA Corporation).$^{65}$ South Australia is scheduled to participate in the national electricity market in $1998 .{ }^{66}$ 


\section{Western Australia}

Western Australia accounts for 7.6 percent of Australia's generating capacity (Table 15). In January 1995, the vertically-integrated state-owned utility, State Electricity Commission of Western Australia, was divided into two independent electricity and gas corporations, trading as Western Power and Alinta Gas, respectively (Table 18). Both corporations are currently state-owned. However, the Western Australia government has now decided to permit foreign investment in independent electricity generation, separate and apart from the Western Power and Alinta Gas operations. In 1995, Edison International (a U.S. company), through its subsidiary Mission Energy, began a project to build a $\$ 111$-million power plant. ${ }^{67}$

Like Queensland, Western Australia is also privatizing other energy assets. Western Australia has announced its intention to privatize its gas pipelines. The CMS Gas Transmission Storage Company (gas pipeline), a subsidiary of CMS Energy (a U.S. company), will purchase a 100-percent interest in the West Australia Natural Gas (WANG) Pipeline near Perth, Australia. In addition, the company will purchase the Western Australia petroleum assets operated by Chevron, Texaco, Mobil and Shell. ${ }^{68}$

\section{Tasmania}

The Hydro-electric Commission of Tasmania (HEC) passed legislation in June 1995 to allow the entry of new participants and extend customer choice in the industry (Table 18). The HEC remains a vertically-integrated, state-owned electricity business with separately organized generation, transmission and distribution. A 1993 feasibility study concluded that while it was technically possible to construct a subsea-link between the states, the project would not be economically viable until the year $2000 .^{69}$ In April 1997, the government announced intentions to introduce retail competition in its electricity industry and to sell some of its equity interest. ${ }^{70}$

\section{Snowy Mountains Hydro-electric Scheme}

The Snowy Mountains Hydro-electric Scheme is a cooperative venture between the Australian Commonwealth government, New South Wales, and Victoria. It represents a vital part of both Victoria's and New South Wales' electricity supply arrangements. The Scheme sells power to the central government of Australia and to the electric distributors in the states of New South Wales and Victoria. It has a generating capacity of 3,740 megawatts, representing over 10 percent of Australia's capacity.

Under the national electricity market reforms, the Scheme will not compete with New South Wales and Victoria in generation. However, prior to the completion of the national electricity market, the Scheme will be corporatized. It will then be expected to sell electricity on the national grid in competition with other state and interstate generators.

\section{Reforms in Price Regulation}

The current Australian national electricity reform aims to create a fully competitive national market in the generation and marketing sectors and to provide the incentives for efficient outcomes at the state level in the transmission and distribution sectors. ${ }^{71}$ The price for electricity generation will be determined by the spot price or the pool price. As in the United Kingdom, Australia has instituted a form of price and revenue cap regulation that has been applied to the transmission and distribution sectors (because these segments are still deemed natural monopolies).

Currently, only the states of New South Wales and Victoria have a wholesale power generation market and have instituted reforms in price regulation (the Australian Capital Territory is participating in the national electricity market via the New South Wales electricity system). The other states that will participate in the national electricity market do not have a state-level wholesale power generation market. Since the first phase of the national electricity market (NEM1) is already underway, Queensland will not develop its own price arrangements prior to participating in the national electricity market but will operate its electricity system on the basis of rules specified in the Code.

\section{The National Australian Power Pool}

The planned national electricity market is designed around a power generation pool (or spot market). The pool ensures that the demand and supply of electricity are balanced at all times-every day is divided into half hour segments. Prices are effective for these half-hour periods and this price is paid to any generator supplying electricity during that period and is the same price charged to any customer who consumes it during that period. All generators with a generating capacity of greater than 30 megawatts are required to participate in the national market. Customers with an annual usage of at least 10 megawatts will be eligible to participant in the market, along with retail electricity suppliers. Generators and customers must submit their bids 24 hours in advance to specify the amount of power and the price they will supply and purchase generation, respectively.

Currently, the national electricity market's power pool is operating in a transitional phase, NEM1. In NEM1, the goal is to integrate the wholesale power markets of $\mathrm{New}$ 
South Wales and Victoria into one market in order to ease the eventual full transition to the national electricity market.

In the operation of NEM1, there is a central entity (called the "interconnection scheduling module") where both states' transmission operators, the TransGrid (New South Wales) and the Victorian Power Exchange (Victoria), submit the generation bids and the estimated electricity demand of their individual states. In turn, the demand for generation is forecast, and the amount of interstate power trading between the states is determined. A dispatch order is established and is sent back to each state market operator (TransGrid and the Victorian Power Exchange), who dispatches generation. The price of the highestpriced generator dispatched in a given period (the "marginal" generator) sets the pool price for that period. This price is received by all generators who dispatch electricity in that period and is paid by customers who take electricity.

After the National Electricity Code is approved and the full national electricity market is implemented, the National Electricity Market Management Company (NEMMCO) will assume the functions of the interconnection scheduling module.

The Code realized that in order to give the correct market signals in the spot market, it is important for the spot price to be allowed to approach realistically high values. The Code also recognizes that in an immature market, such as Australia, allowing the spot price to operate at a level where supply and demand are balanced may result in a very high price which would expose inexperienced participants to unnecessarily high financial risks. Therefore, the Code makes provisions for a temporary Value of Lost Load (VoLL) price cap. The price cap is set (in Australian dollars) at $\$ 5$ per kilowatt hour. ${ }^{72}$ The Code set the value of the price cap at this level in order to strike a balance between the highest price that purchasers of power might consider acceptable and a price high enough to ensure that generators would not be discouraged from investing in plants with high operating costs.

In the implementation of the full national nnarket, the National Electricity Market Management Company (NEMMCO) will be responsible for the operation of the power pool and the short-term forward trading market.

At the state level, the wholesale power generation market operates almost like the operations contemplated for the national electricity market (the fully transitional national market will begin in the first half of 1998). The state (Victoria and New South Wales) operates its own pool, and generators compete in the pool to supply the energy needs of their individual states (Figure 10 and Figure 11). The wholesale power market in New South Wales began in 1996. Victoria's wholesale power market began in 1994. In NEM1, generators in Victoria and New South Wales will supply electricity to an integrated wholesale power pool, and (through that pool) they will compete with each other to supply the combined energy needs of the two states and the Australian Capital Territory.

\section{Price and Revenue Cap Regulation}

Pricing in the transmission and distribution sectors of the Australian electricity industry are set by a cap, above which prices or revenues are not permitted to rise. Victoria's tariff regulation is mainly a price cap. ${ }^{73}$ A price cap consists of a ceiling where a company has complete price flexibility as long as its price stays below that level; that is, prices can move up and down but they must stay under (or at) the ceiling. The price cap can serve to keep prices (both unit electricity costs and distribution network costs) from rising too high, and it can protect electricity customers from large and/or frequent price fluctuations. It can also provide an incentive for productivity improvement and cost efficiency. In other words, operators have incentives to cut costs and increase efficiencies. ${ }^{74}$ However, it can also result in unusually high levels of profitability, which can raise public concern.

The price cap is commonly referred to as " $\mathrm{CPI}$ (Consumer Price Index) minus X." As in the United States, the "CPI" is a measure of inflation. The " $X$ " is a productivity factor. The theory behind the use of the "CPI- $X$ " price ceiling is that a regulated company must be allowed to recover inflationary increases in its input costs, but should not receive additional benefit from productivity improvements that result in lower operating costs which also offset inflationary increases in input costs. The Australian CPI-X formula is similar to the RPI- $X$ form of regulation adopted in the United Kingdom. (See the section in Chapter 2 entitled "RPI-X: Rate Caps versus Rate-of-Return Regulation" for further details on UK price-cap regulation.)

In New South Wales, a revenue cap is applied in the transmission and distribution sector. ${ }^{75}$ Revenue cap regulation works much the same way as price-cap regulation. However, instead of indirectly limiting a company's revenues by controlling its prices (the price-cap approach), under a revenue cap the CPI-X formula directly limits the total amount of revenue a company can receive.

\section{Future Regulation of Transmission and Distribution Sectors}

Currently, the regulations for both transmission and distribution are established by state regulators. The 
regulator in New South Wales is the Independent Pricing and Regulatory Tribunal, and the regulator in Victoria is the Office of the Regulator General. (As previously stated, Victoria's electricity tariff regulation is mainly a price cap, whereas in New South Wales a revenue cap is mainly applied.) Regulatory arrangements in transmission pricing under state jurisdiction will end in June 1999 in New South Wales, and in December 2000 in Victoria. ${ }^{76}$ Thereafter, the Australian Competition and Consumer Commission (ACCC) will become responsible for transmission regulation. The ACCC has not made a final decision on the regulatory guidelines and rules to be used in determining transmission pricing except that the guidelines will be cost-reflective and will utilize revenue or price capping or a combination of both. After this decision has been made, transmission network service providers must develop their own pricing structures and tariffs and submit them to the ACCC for approval. Additionally, the ACCC will produce a "Statement of Regulatory Intent," which will establish guidelines as to how it will exercise its power in this regulatory area. ${ }^{77}$

In the area of distribution, the Code provides national objectives and economic principles that each state should follow; however, the states retain jurisdiction over distribution pricing. The Code recognizes that it may be inappropriate to apply national guidelines to state jurisdictions because of existing distribution service pricing regimes. Nonetheless, the Code has made provisions which allow the states to develop a set of national guidelines for distribution service pricing. However, any such proposed distribution pricing guidelines must be unanimously approved by all of the states and must not conflict with or override any pre-existing distribution regulations in any of the individual states. ${ }^{78}$

The ACCC will be responsible for three missions. First, it will ensure that economic efficiency gains are realized by customers (in terms of price, level of service, and quality of service) and by generators (in terms of optimizing their generating plants and lowering operating costs). Second, its role is to ensure that generators do not raise prices to reap excessive profits. Third, it will ensure that anti-competitive pressure is not exerted by generators to exclude potential competitors from entering the market. ${ }^{79}$

\section{Privatization and Reform Outcomes}

\section{Investment in Australia}

The level of foreign investment in the Australian electricity industry has increased and is expected to continue to expand as reforms and privatization in the electricity industries continue. ${ }^{80}$ The reforms aimed at developing fair and open competitive markets are leading to opportunities for private investment in the electric industry. In 1995, the direct investment position in Australia in the category "other industries" (of which electricity is the major part) almost tripled from the prior year's level partly due to the acquisition of Australian electricity assets. ${ }^{81}$ (According to the U.S. Department of Commerce, direct investment involves the establishment of a new firm, the expansion of an existing firm, or the acquisition of a business enterprise or real property in which a foreign person or company obtains direct or indirect ownership of at least ten percent of controlling equity). ${ }^{82}$ The 1995 total direct investment position in Australia (by the United States and other countries) was $\$ 104.2$ billion, a $\$ 13.1$ billion increase from investment during the prior year (Figure 12). ${ }^{83}$ Of this increase ( $\$ 13.1$ billion), the United States accounted for almost $\$ 5$ billion and total direct investment has increased every year since 1988 (Figure 13).

Figure 12. Total Direct Investment in Australia, Selected Years

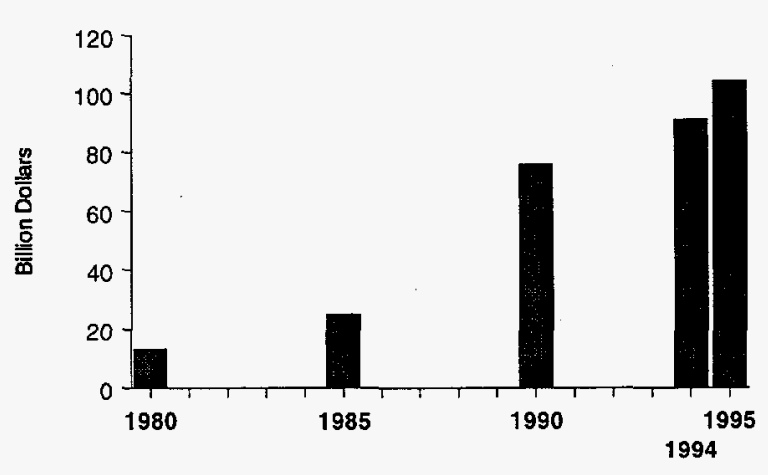

Source: United Nations Conference on Trade and Development, World Investment Report 1996, Investment, Trade and International Policy Arrangements, (New York, New York: United Nations, 1996).

American companies' attraction to foreign investment in Australia can in part be traced to the passage of the 1992 Energy Policy Act in the United States, which, for the first time, permitted U.S. utilities to own an equity interest in foreign utilities.

The introduction of electricity reform in Australia has given U.S. companies (as well as companies from other countries) the opportunity to invest in an electricity system which has the potential for improved efficiency. In fact, some U.S. companies have stated that investments in Australia's electricity market would give them expertise in operating in a deregulated electricity market and therefore would give them an added advantage when deregulation begins in the United States.$^{84}$ Slow economic 
Figure 13. U.S. Direct Investment Position in Australia, 1988-1995

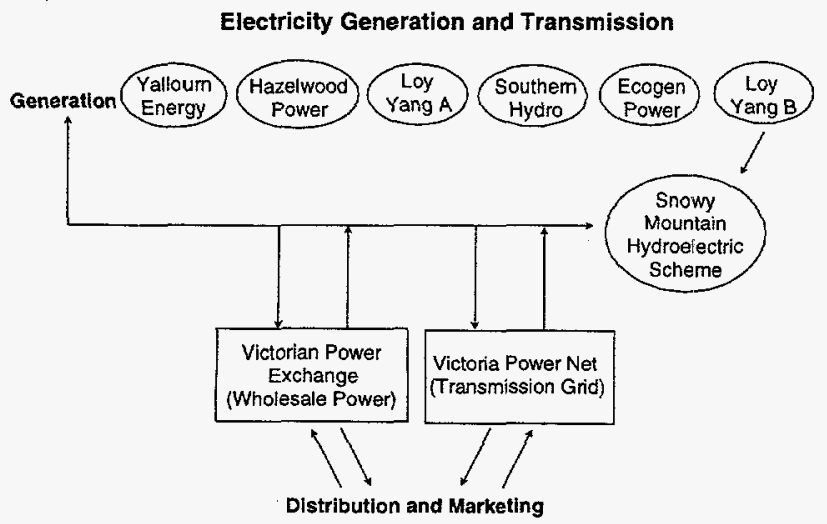

Note: The other industries category of foreign direct investment includes electric utilities, natural gas and sewage. The data for other industries between the years of 1988 and 1990 are close to zero.

Source: United States Department of Commerce, Bureau of Economic Analysis, Survey of Current Business, various issues.

growth in the United States, Australia's low political risk, and their new regulatory climate for electricity are additional factors. ${ }^{85}$ Efficiency gains are already evident in New South Wales and Victoria, the two states with the greatest degree of reform and privatization.

\section{Prices, Labor Productivity and Customer Service}

In February 1997, the New South Wales Independent Pricing and Regulatory Tribunal reported that wholesale electricity prices in Australia have steadily decreased since 1993, representing a 32-percent drop in real terms over a four-year period. ${ }^{86}$

Victoria has also realized a decline in electricity prices of 6 percent as well as improvements in service quality. Due to continued improvements in labor productivity between the years of 1991 and 1995, returns on assets have also increased. The labor productivity increases have, in particular, been attributed to Victoria's reform and privatization efforts. ${ }^{87}$

An Australian Chamber of Manufacturers' (ACM) survey of its contestable customers (large end users) in Victoria reported that approximately 2,500 Victorian companies were eligible to enter the wholesale power market in 1996. The survey was developed to examine prices, customer satisfaction with service, and supply conditions in the market. Of the 800 contestable customers who were given the survey, the ACM had 312 respondents. Of the 312 respondents, about 78 percent of the respondents believed their negotiated electricity prices were cheaper compared to rates prior to the 1994 beginning of the Victorian wholesale power market. Only 10 percent believed they were worse off under the new arrangements. The average price reduction response per respondent was about 10 percent, with savings varying between 1 percent and 39 percent. While price was the major consideration for most customers when choosing a supplier, almost 33 percent of the contestable customers reported an improvement in service, while almost 64 percent reported no change. As for supply conditions, of the 312 respondents, 93 percent had negotiated a new contract subsequent to the 1994 reform. Thirty-five percent of the respondents who had negotiated a new distribution contract had also changed their electricity supplier. ${ }^{88}$

In constructing its national electricity market reform, Australia plans to expand upon the UK model by large end users (contestable customers) to directly compete for generated power in the national electricity pool. This concept was tested (on a smaller scale) by allowing these customers to compete for power within the individual power pools of their own states (first in Victoria in 1994, and then in New South Wales in 1996).

If the results of the ACM survey of this type of customer (large end users) are considered to be representative of all of the large end users in Australia, several questions might arise. Why are the majority of these customers choosing to use the marketing services of a distributor to compete in the power pool on their behalf, instead of cutting out this "middleman" and directly competing for their own power needs themselves, as the electricity reform allows? The answer to this question is not entirely clear. It may be that the large end users need time to acquire the skills and gain the experience necessary to effectively operate in the competitive power pool process. It may also be that purchasing these services through contractual arrangements from a distributor experienced in the power pool bidding process lowers the risk of pool competition for a relatively small charge. Perhaps purchasing these services is simply more convenient. Or, it is possible that this trend (of large end users retaining distributors to compete for power on their behalf) is transitory, and that more and more of these customers will compete in the power pool as they acquire the necessary skills to do so. As the national electricity market in Australia matures, the nature of the relationship between "middleman" distributors / marketers and large end users requiring power from the national pool may become more apparent. 


\section{Endnotes}

${ }^{1}$ Australia has six states-Victoria, New South Wales, Queensland, South Australia, Western Australia, Tasmania-and two mainland territories-Australian Capital Territory and Northern Territory.

${ }^{2}$ Victoria, New South Wales and the Australian Capital Territory are the only states and territory that are currently interconnected to form a grid.

${ }^{3}$ Robin Davey, APEC Electricity Regulators' Forum, Summary Submission: Australia (July 9, 1996), p. 1.

Electricity generation is fueled mainly by coal in all the states of Australia except in Tasmania. Electricity generation in Northern Territory is also fueled mainly by coal. Ninety percent of Tasmania's electricity generation is supplied by hydropower. South Australia rely heavily on gas turbine combustion. The Snowy Mountains Hydro-electric Scheme contributes 11 percent of the total electricity generation in Australia.

${ }^{5}$ Australian Bureau of Statistics, Year Book Australia 1997 (Canberra, New South Wales, 1997), p. 445; International Energy Agency, Energy Policies of IEA Countries: 1996 Review (Paris, France: Organization for Economic Cooperation and Development, 1996) p. 108; and Australian Electricity Task Force, Summary of Electricity Market Reforms in Australia (May 1997), p. 1.

${ }^{6}$ N. Cain, "Australia-Power Generation Profile," 1995 Trade Data Bank: Market Reports (December 14, 1995), p. 2.

${ }^{7}$ N. Cain, "Australia-Power Generation Profile," 1995 Trade Data Bank: Market Reports (December 14, 1995), p. 2.

${ }^{8}$ N. Cain, "Australia-Power Generation Profile," 1995 Trade Data Bank: Market Reports (December 14, 1995), p. 2.

${ }^{9}$ Robin Davey, APEC Electricity Regulators' Forum, Summary Submission: Australia (July 9, 1996), p. 1.

${ }^{10}$ In this paper it is assumed that the exchange rate is US $\$ 0.74$ equal A $\$ 1.00$ currency.

${ }^{11}$ Robin Davey, APEC Electricity Regulators' Forum, Summary Submission: Australia (July 9, 1996), p. 1.

${ }^{12}$ Organization for Economic Cooperation and Development, "Electricity Supply Industry: Structure, Ownership and Regulation in OECD Countries, Part 3 Country Annexes" (1994), pp. 162 and 163.

${ }^{13}$ Empowering the Market: National Electricity Reform For Australia, (Melbourne, Victoria:National Grid Management Council, 1995), p. 2 and 3

${ }^{14}$ The National Electricity Code. <http://acc.gov.au/shed/httoc.htm7>

${ }^{15}$ International Energy Agency, Energy Policies of IEA Countries: Australia (Paris, France: Organization for Summary of Market Reforms in Australia, March 1997) Chapter 8.

${ }^{16}$ Organization for Economic Cooperation and Development Economic Surveys: Australia 1996 - 1997 (December 1996), pp. 123 and 191; and Council of Australian Governments, "Communique," Canberra, New South Wales (April 11, 1995).

${ }^{17}$ International Energy Agency, Energy Policies of IEA Countries: Australia (Paris, France: Organization for Summary of Market Reforms in Australia, March 1997) Chapter 8.

${ }^{18}$ The national electricity grid is the combination of all the electricity poles, wires and cables within the southern and eastern states of Australia-- New South Wales, Victoria, South Australia, Queensland, Tasmania, in addition to the Australian Capital Territory. Western Australia and the Northern Territory are not involved in the national electricity market due to distance and cost factors.

${ }^{19}$ Organization for Economic Cooperation and Development Country Analysis: Australia (March 1997), p. 93.

20 "Australian States Agree on Route for Electricity Grid Link," Dow Jones Newswire (June 6, 1997), p.1.

${ }^{21}$ Organization for Economic Cooperation and Development Country Analysis: Australia (March 1997), p. 93.

2The first phase of the national electricity market was expected to begin in 1995 and was later rescheduled to 1996. VPX: Market Update, March 1997 vol 3 Issue $2 ;<$ http://electricity.net.au/update>

${ }^{23}$ Empowering the Market: National Electricity Reform For Australia, (Melbourne, Victoria: National Grid Management Council, 1995 ), p. 7.

${ }^{24}$ Electricity Legislation And Codes - Australia, <http/www/ccw.com.au/ccwpub/22fa.htm>

${ }^{25}$ Some of the generation power plants are publicly owned, such as Electricity Trust of South Australia and some are privately operated, such as Mission Energy's Loy Yang B plant.

${ }^{26}$ Market Trading Working Group, Restructuring of the Electricity Supply Industry in Australia, (National Grid Management Council, September 1995), $<\mathrm{http} / \mathrm{www} / \mathrm{energyonline.com/Restructuring/models/2austtoc.html>}$

${ }^{27}$ Ibid.

${ }^{28}$ Robin Davey, APEC Electricity Regulators' Forum, Summary Submission: Australia (July 9, 1996).

${ }^{29}$ Choice of Electricity Retailer: For Customers with Consumption Greater than $750 \mathrm{MWh}$ per year (Victoria: Office of the Regulator-General, Victoria, February 1996).

${ }^{30}$ Choice of Electricity Retailer: For Customers with Consumption Greater than 750 MWh per year (Victoria: Office of the Regulator-General, Victoria, February 1996).

${ }^{31}$ UtiliCorp United will manage the utility operations and hold a 49.9 percent ownership interest and the remainder of the ownership will be owned by AMP Investments with almost 41 percent and State Superannuation Investment and Management Corporation with 9 percent.

32، UtiliCorp Says Earnings of Australian Electric Operations Exceed Expectations," Business Wire (May 15, 1996); and "UtiliCorp Expand Again, Wins Australian Utility Bid," The Energy Daily (August 8, 1995).

33،"UtiliCorp United Plans to Bid on More Projects in Australia," Kansas City Business Journal (August 18, 1995), Section 1, p. 4.

${ }^{34}$ "GPU Subsidiary Energy Initiatives to Acquire Half Ownership of Solaria Power Ltd., an Electricity Distribution Business in Australia," Business Wire (October 30, 1995), p. 1 .

35“"T. U. Beats Out PG\&E and PacifiCorp for Eastern Energy of Australia," Electric Utility Week (November 20, 1995), p. 15.

36"PacifiCorp Hikes Australian Presence by Acquiring Share of 1,600-MW Plant," Electric Utility Week (August 12, 1996), p. 15.

37،1995: The Year In Review," The Energy Daily ( January 2, 1996); "Entergy Opens Sydney, Australia Office," PR Newswire ( September 19, 1996); and "Global Expansion," Electric Light \& Power (January 1996).

38 “Australia: Loy Yang B Sale Slàshes Victoria's Risk Exposure,” Dow Jones Newswire (May 5, 1997), p. 1.

39"PacifiCorp Hikes Australian Presence by Acquiring Share of 1,600-MW Plant", Electric Utility Week (August 12, 1996), p. 15.

Worthern States Power, Central and South West, Consumers Power affiliate CMS Generation, American Electric Power, Public Service Electric and Gas affiliate Community Energy Alternatives, and Duke Power. "U.S. Utilities Dominate Shortlist for 1,450-MW Plant in Australia", Electric Utility Week (December 18, 1995).

41" PacifiCorp Hikes Australian Presence by Acquiring Share of 1,600-MW Plant", Electric Utility Week (August 12, 1996), p. 15. 
${ }^{42} \mathrm{CMS}$, NRG Energy and Horizon Energy Australia Investments Close on Acquisition of Australia's Loy Yang A Plant and Coal Mine", PR Newswire (May 12, 1997). Other bidders were Transpower, a subsidiary of U.S.-based AES Corporation, in a consortium with Singapore Power Ltd. and U.S.-based American Electric Power and China Light Power

43 "CMS-Led Group in Australian Power Plant Deal," New York Times (April 23, 1997), p.

44"Mission to Buy Rest of Lo-Yang B," Power In Asia (April 7 1997), p. 25; and (January 13, 1997), p. 29.

45"Victoria \$10bn Power Sale," Power In Asia (January 13, 1997), p. 29; and "Victoria to Sell," Power In Asia (May 5, 1997 ), p. 26.

${ }^{46 ،}$ Electricity Generation, Structural and Regulatory Reform in Australia,"Australian Commodities, Vol 2, No. 3(September 1995), pp. 358-373.

${ }^{47}$ Robin Davey, APEC Electricity Regulators' Forum, Summary Submission: Australia (July 1996). IEA Countries: Australia, p. 91.

${ }^{48}$ Australia's NSW Welcomes Foreign Buyers In Electricity Sale," Dow Jones Newswire (May 27, 1997), p. 1.

49،"Australia: NSW Electricity Sale Faces Opposition-Amplifier," Dow Jones Newswire (May 27, 1997), p. 1.

50، Australia's NSW Welcomes Foreign Buyers In Electricity Sale," Dow Jones Newswire (May 27, 1997), p. 1.

51،"Deals of the Year: The Annual Financing Review - Froject Finance," Asia Money (February 1996), pp. 37-46. The Smithfield plant is the largest co-generating plant in Australia.

${ }^{52}$ Sithe Energies, Inc., Securities and Exchange Commission Form 10-K, 1995, p. 3. Cogeneration is the simultaneous production of two or more useful forms of energy, such as electricity and steam, from a single primary fuel source.

53،"Transfield Set for 160 MW Congen Unit for NSW," Power In Asia (April 28, 1995), p. 25.

${ }^{54}$ "Energy Australia Sells Out of $\$ 215 \mathrm{mln}$ Botany Project," Asia Pulse (March 20, 1997); and "Air Liquide to Build Australia's Biggest Combined Heat and Power Plant," European Report (May 29, 1996).

${ }^{55}$ Corporatized - the entity will remain in the public sector with a board nominated by the states but their functioning and legal obligations are identical to those in the private sector.

${ }^{56}$ Robin Davey, APEC Electricity Regulators' Forum, Summary Submission: Australia (July 9, 1996); and "Introducing Competition in A.C.T. Electricity Retailing," A.C.T. Government, Department of Urban Services (December 1996).

${ }^{57}$ Robin Davey, APEC Electricity Regulators' Forum, Summary Submission: Australia (July 19. 1996), p. 24.

58 "Australian States Agree on Route for Electricity Grid Link," Dow Jones Newswire (June 6, 1997), p.1.

59“"Queensland Energy Minister Decides Not to Sell 5,315-MW Austa Electric," Independent Power Report (December 27, 1996).

60"BHP Unit Cleared by W.A.," Power In Asia (May 15, 1995), p. 24.

61“"Australia: Queensland Electricity Mkt On Track - Minister," AP-Dow Jones News Service (April 23, 1997).

62،"Shell Makes Move to Sell Power," Power In Asia (April 7 1997), p. 25.

63" Progressive Change," Independent Energy (July/August 1996), pp. 27-31.

${ }^{64}$ Robin Davey, APEC Electricity Regulators' Forum, Summary Submission: Australia (July 19. 1996), p. 24.

${ }^{65} J$ ohn Landels AC, "National Electricity Market Developments in Australia" (National Grid Management Council, Australia: June 1997). Paper presented at the Edison Electric Institute.

${ }^{66}$ Transgrid, NEM1: Gateway to the National Electricity Market (Implementation Edition, May 1997), http://www.tg.nsw.gov.au/sem/doc/reports/nem1gateway/(May, 1997).

${ }^{67}$ The San Diego Union-Tribune (February 25, 1997), p. C1.

${ }_{68 . " C M S}$ Energy's International Gas Pipeline Unit Acquires Western Australia Natural Gas Pipeline Serving Perth," PRNewswire (May 9,1997).

${ }^{69}$ Robin Davey, APEC Electricity Regulators' Forum, Summary Submission: Australia (July 9, 1996), p. 24.

${ }^{70} \mathrm{John}$ Landels AC, "National Electricity Market Developments in Australia" (National Grid Management Council, Australia: June 1997). Paper presented at the Edison Electric Institute.

${ }^{71}$ Robin Davey, APEC Electricity Regulators' Forum, Summary Submission: Australia (July 9, 1996), pp. 6-11.

${ }^{72}$ National Electricity Code, Chapter 3.9. <http://electricity.net.au/code_r.htm>

${ }^{73}$ Organization for Economic Cooperation and Development, Country Analysis: Australia (March 1997), p. 96.

${ }^{74}$ Robin Davey, APEC Electricity Regulators' Forum, Summary Submission: Australia," (July 9, 1996), p. 96.

${ }^{75}$ Organization for Economic Cooperation and Development, Country Analysis: Australia (March 1997), p. 96.

${ }^{76}$ State regulator control in Queensland and Australia Capital Territory will both end in June 1999; and South Australia in December 2000. Source: National Electricity Code, Chapter $6.2,<\mathrm{http} / \mathrm{www}$.electricity.net.au/code_r.htm $>$.

${ }^{77}$ National Electricity Code, Chapter 6.10. <http://electricity.net.au/code_r.htm>

${ }^{78}$ National Electricity Code, Chapter 6.10. <http://electricity.net.au/code_r.htm $>$

${ }^{79}$ Robin Davey, APEC Electricity Regulators' Forum, Summary Submission: Australia," Regulator General Victoria, Australia (July 9, 1996).

${ }^{80}$ Australia is also currently undertaking efforts to deregulate its natural gas industry. Natural gas is expected to increase its share of the electric utility industry's fuel market.

${ }^{81}$ United States Department of Commerce, Bureau of Economic Analysis, Survey of Current Business, various issues.

${ }^{82} \mathrm{H}$. A. Poniachek, Direct Foreign Investment in the United States, (Lexington, Massachusetts:Lexington Books), p. xi.

${ }^{83}$ United Nations Conference on Trade and Development, World Investment Report 1996, Investment, Trade and International Policy Arrangements, (New York, New York: United Nations, 1996).

${ }^{84}$ "PacifiCorp Hikes Australian Presence by Acquiring Share of 1,600-MW Plant," Electricity Utility Week, (August 12, 1996 ), p. 15.

${ }^{85}$ "International Investing by U.S. Utilities", Institutional Investor, Inc.(October 1996), p. 3.

86 "NSW Takes the Low Road," Power In Asia (February 10, 1997), p. 26.

${ }^{87}$ Robin Davey, APEC Electricity Regulators' Forum, Summary Submission: Australia (July 9, 1996).

88"Customer Feedback on Victoria's Competitive Electricity Market: A Report on the ACM Survey of Contestable Electricity Customers," Australian Chamber of Manufactures, (November 1996). 


\section{Chapter 4}

\section{The Transformation of Argentina's Electricity Industry}

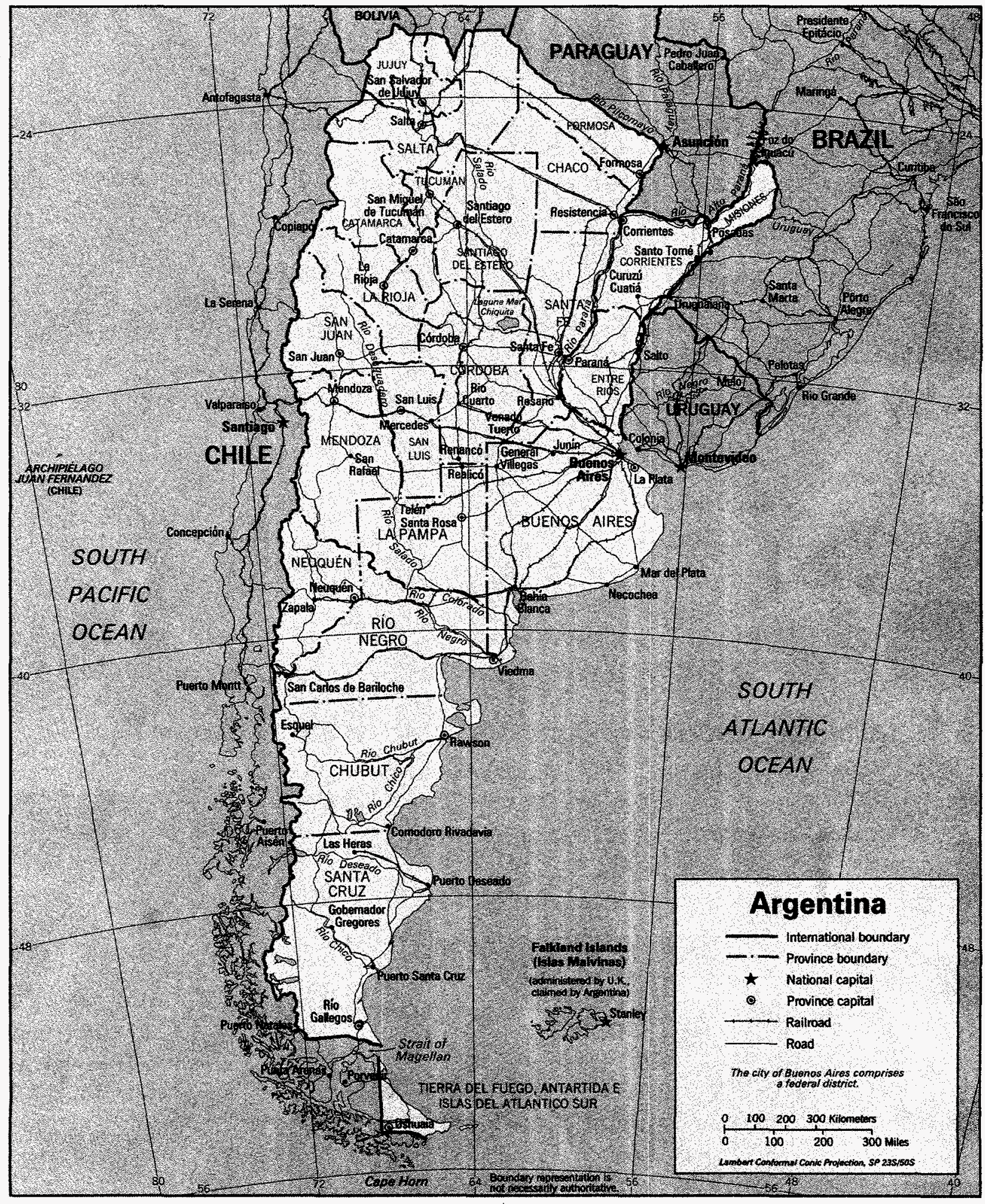





\section{The Transformation of Argentina's Electricity Industry}

Argentina's economy of the 1980's was engulfed in numerous problems, some of which could be traced to developments in the 1940's. Economic problems of hyperinflation, low economic growth, and rising national debt were worsened by a deteriorating infrastructure, including the electricity infrastructure. ${ }^{1}$ Hyperinflation was dramatically reduced following passage of the Convertibility Law of 1991, which formally initiated thenEconomy Minister Cavallo's plan to align Argentina's peso to the U.S. dollar. Additionally, the law required 100-percent backing of the nation's currency by foreign reserves. ${ }^{2}$ The decision to link the Argentine peso to the U.S. dollar limited Argentina's available solutions to other problems (for example, low economic growth) by severely limiting discretionary changes in the nation's money supply. Thus, privatization was not only an action that could solve many of Argentina's remaining problems (i.e., rising debt and deteriorating infrastructure) but also an action that was permissible under the new economic plan.

Privatization directly addressed the problem of rising debt by divesting inefficiently-operated assets and companies. In addition, it was expected that the new owners of privatized assets would improve the assets, thereby upgrading Argentina's infrastructure. Further, privatization indirectly addressed the country's economic problems by providing Argentina's treasury with a financial cushion while the fiscal reforms ${ }^{3}$ worked through the economy. ${ }^{4}$ Privatizations also were a solution for a number of other problems (such as the absence of competition to spur the reduction of production costs) that tend to drain the national treasury, and that often are attributed to publicly-operated companies as opposed to similar privately-operated companies. ${ }^{5}$ Finally, as in the Australian state of Victoria and the United Kingdom (UK), a surge in foreign investment accompanied electricity privatization in Argentina.

\section{A Historical Perspective for Argentine Privatization Efforts}

The Argentine privatization that began in 1992 was the most recent of a series of privatizations. As early as the late 1950 's and early 1960 's, Argentina privatized some nationalized industries. Again, during the 1970's, another wave of privatization was undertaken, resulting in the sale of 120 companies. ${ }^{6}$ Attempts to increase the efficiency of remaining public companies during the late 1970's and 1980 's were largely unsuccessful. For example, the 13 largest public companies in Argentina (exclusive of defense) had an operating deficit of $\$ 3.8$ billion on revenue of $\$ 8.7$ billion during 1989. During the first half of 1990 , the operating deficit grew another 35 percent.

The country's inability to resolve these problems led to the 1992 privatization program. By this time, Argentina's electricity industry "...had deteriorated badly and was characterized by severe operational and financial difficulties... ."7 The industry was constantly threatened with the possibility of blackouts, a threat which worsened during periods of relatively little rainfall (such as the summer) because of Argentina's reliance on hydroelectric power generation (Table 19). Electricity was also expensive and often stolen by consumers either through illegal hook-ups or by failure to pay bills. ${ }^{8}$ (Argentina's problems were similar to those of other Latin American countries. For a brief review, see the text box entitled, "Historical Overview of Latin American Electricity.") Despite these problems, the industry achieved a positive growth rate. For example, between 1985 and 1991, net production of electricity increased 19 percent, averaging slightly more than 3 percent annually. However, since privatization began in 1992, the growth rate of electricity production has doubled. Between 1992 and 1995, net production of electricity in Argentina has increased 22 percent, averaging slightly less than 7 percent annually. Argentina's electric industry problems included recurring power outages, substantial and regular unavailability of power generators, and rampant theft of electricity. Given these problems and Argentina's economy-wide problems, the dramatic increase in electricity production that has accompanied privatization demonstrates the extent of its effectiveness.

Argentina's privatization was modeled after Chile's with modifications introduced to correct problems encountered by Chile. Argentina began privatization of its electricity industry more than ten years after Chile privatized its 
Table 19. Net Production of Argentine Electricity by Independent and Public Producers, 1985-1995 (Million Kilowatt Hours)

\begin{tabular}{|c|c|c|c|c|}
\hline Year & Thermal Generation & Hydro Generation & Nuclear Generation & Total Generation \\
\hline $1986 \ldots$ & 20,922 & 20,796 & 5,383 & 47,101 \\
\hline 1988 & 29,585 & 15,633 & 4,845 & 50,063 \\
\hline $1989 \ldots$ & 30,522 & 13,195 & 4,787 & 48,504 \\
\hline $1991 \ldots \ldots \ldots \ldots$ & 28,055 & 16,267 & 7,695 & 52,017 \\
\hline $1992 \ldots$ & 27,844 & 19,375 & 6,745 & 53,964 \\
\hline 1993 & 28,794 & 23,907 & 7,315 & 60,016 \\
\hline $1994 \ldots \ldots \ldots \ldots$ & 28,685 & 27,116 & 7,823 & 63,624 \\
\hline $1995 \ldots \ldots \ldots \ldots$ & 28,650 & 30,000 & 7,070 & 65,720 \\
\hline
\end{tabular}

Sources: 1990-1995: World Energy Database, http://www.eia.doe.gov/emeu/world/ contents.htmr, 1985-1989: International Energy Database, International Statistics Branch, Energy Markets and Contingency Information Division, Office of Energy Markets and End Use, Energy Information Administration, May 1997.

\section{Historical Overview of Latin American Electricity}

Until the post-World War II period, most electricity in the Latin American countries was provided by private firms. This also was the case in Argentina. However, due to widespread confiscatory government policies, Latin American capital markets of the post-War period remained undeveloped.

In the 1950's and 1960's, in an attempt to better provide capital, most Latin American countries began to nationalize their key industries. The Argentine electricity industry was one of the industries nationalized. As the nationalism movement swept Latin America, foreign ownership and participation in energy industries became politically difficult. ${ }^{2}$

Nonetheless, the investment necessary for power generation in Latin America was substantial. The region experienced considerable economic growth in the 1960's and the 1970's. For example gross domestic product, adjusted for inflation, expanded at a 6-percent annual rate over the period (per capita growth was 4 percent). Concurrently, total electricity consumption grew about 20 percent during the 1970 's (per capita electricity consumption grew more than 7 percent). ${ }^{b}$

Latin American electrification was fueled by this growth. At the outset of the 1950's, approximately 30 percent of Latin America had access to electricity. By the end of the 1970's 70 percent of the region had access to electricity. The general opinion of the time was that "only the state had both the resources and borrowing power to finance the public utilities industry."

However, by the 1980's, Latin America faced a major debt crisis. Substantially reduced economic growth caused by falling oil prices and reduced government spending contributed to the crisis. In addition, the Latin American electricity infrastructure had become antiquated. A general record of poor maintenance and operational inefficiencies complicated the problem.

As in the 1950's and 1960's, Latin American governments once again sought ways to improve their access to capital. For many countries, especially Argentina, this desire became one of the driving forces in the resulting industry privatizations of the 1990's. As a result, the Latin American electricity industry now has become a prime target of privatization and reform efforts.

${ }^{a}$ Although five private electricity companies survived the period of nationalization that swept Latin America, none of these companies were in Argentina, whose electricity industry became publicly-owned. The companies were in Venezuela (owned by Venezuelan investors), Bolivia (owned by Canadian investors), Ecuador (owned by one U.S. investor), Barbados (owned by investors of Barbados, Canada and the United States), and EI Salvador (owned by U.S. investors).

'Everett J. Santos, "The Push to Privatize: Developing Essential Infrastructure in Latin America," Latin Finance, Number 44 (January 1993), p. PR4.

'Santos, p. PR4. 
industry. The features of Chile's privatized electricity industry that Argentina adopted included open access to the wholesale electricity market guaranteed by law despite widely dispersed generation plants, and dispatch of electricity based on the production costs of the available generators, with the lowest-cost generation dispatched first. However, Argentina, unlike Chile, required complete separation of transmission from generation and distribution. Other willful differences in the privatizated industries of the two countries include Argentina's restriction that no single generator provide more than ten percent of national generation capacity.

In 1991, just prior to the beginning of privatization, Argentina's electricity industry included four federal utilities ${ }^{10}$ one Argentina-Paraguay agency (controlling a large hydroelectric plant owned jointly by the two countries), one Argentina-Uruguay agency (also controlling a large hydroelectric plant owned jointly by the two countries), 19 provincial utilities, and several electricity cooperatives. One of the four federal utilities generated and distributed electricity to the greater Buenos Aires and La Plata area, one served the balance of the country's needs for power generation and transmission, ${ }^{11}$ one oversaw the hydroelectric power generators of southern Argentina, ${ }_{1}^{12}$ and one oversaw nuclear power generation plants. ${ }^{13}$ At the time of privatization, the non-nuclear utilities accounted for about 80 percent of the approximately 15,000-megawatt generation capacity of the system. Since 1992, at least some part of each of the first three former federally-owned utilities (the power generation branch of the national atomic energy agency is the lone exception) has been privatized. ${ }^{14}$

\section{Changes in Legislation and International Agreements}

Several legal changes preceded the most recent round of privatization, which began with the passage of two 1989 laws. The first, the Economic Emergency Law, prohibited the Argentine central bank from financing government deficits and suspended all state subsidies and many incentive programs to mining and manufacturing companies. ${ }^{15}$

The second 1989 law was the Administrative Reform Law (Reform Law) ${ }^{16}$ The Reform Law, enacted in September 1989, defined the ground rules for investment in formerly federally-owned companies. The ground rules implicitly allowed foreign investment by not expressly prohibiting it. ${ }^{17}$ Additionally, the Reform Law gave the Argentina federal government authority to privatize federal companies, including the Buenos Aires electricity company. ${ }^{18}$ Although parliamentary approval of privatization sales to domestic companies and/or foreign companies was assured by the Reform Law, further laws to govern the restructuring and privatization of Argentina's different industries were necessary. ${ }^{19}$

Although the 1989 laws allowed foreign companies to invest in Argentina's privatizing industries, U.S. companies were given a further incentive to invest by a 1992 trade treaty. The 1992 Bilateral Investment Treaty accorded U.S. companies the privilege of investing in Argentina's private sector at terms at least as favorable as those accorded domestic investors. ${ }^{20}$

Also during 1992, an electricity privatization law was passed. Public Law 24,065 (Electric Law), enacted in January 1992, established a legal structure for restructuring and privatizing the electricity industry. The federal government intended for the Electric Law to reduce electricity rates and improve service. The restructuring that preceded privatization was designed to lead to competition between the soon-to-be-privatized electricity companies $^{21}$ and was modeled after earlier restructuring by Chile and the price-cap regulation of the United Kingdom. ${ }^{22}$

Two further legal changes occurred during 1993. A 1993 amendment to the Foreign Investment Law $^{23}$ more explicitly addressed the question of foreign investment. This amendment removed restrictions that applied only to foreign investors, freeing them of the need to receive prior approval for most investment. Later in 1993, the measures of the 1989 Economic Emergency Law, the 1989 Reform Law, and the 1993 amendment to the Foreign Investment Law were combined in an act called Decree 1853, which removed most of the remaining restrictions on foreign investment. Decree 1853, with few exceptions, allows foreigners to own 100 percent of Argentine companies, and to freely repatriate the profits and capital to their home country. ${ }^{24}$ The passage of these laws, amendments, and treaties restructured Argentina's legal system to facilitate the sale of government-owned companies and assets, including those comprising the electricity industry.

\section{The Industry Restructuring and Privatization Plan}

The most recent round of privatizations by Argentina was conducted with guidance from the World Bank. ${ }^{25}$ Although the World Bank was not directly involved in each individual privatization, Argentina largely adopted 
the Bank's recommendations in restructuring and privatizing its industries. ${ }^{26}$

\section{Prior to the Initial Sale}

After the passage of industry-specific privatization laws, the companies to be privatized were restructured so that a competitive industry with multiple companies could be created. Regulatory bodies for the newly-privatized industries also were established. Technical specialists defined and structured the assets into viable, independent business units. Legal advisors created charters for new corporations spun off from the privatized entity and prepared bidding documents, contract terms, and conditions consistent with sale objectives ${ }^{27}$ and with the government's intent regarding privatization of the sector. ${ }^{28}$

Financial advisors determined necessary investment and price levels for the viability of the privatized entities. Advisors were paid expenses, an agreed-upon fee, and a bonus linked to the price the government received for the privatization(s) on which they worked. ${ }^{29}$

\section{The Initial Sale}

Privatized companies were sold through auction. The auction method used is known as the "two-envelope" process. ${ }^{30}$ Firms and consortia were prequalified for an intentionally short list of bidders. Those selected as bidders submitted a two-part bid. The first part of the bid was the technical offer, which had to conform with the requirements established by the bidding documents. Firms not meeting the technical requirements were eliminated. The second part of the remaining companies' bids, which contained the financial offers for the assets, were then examined. Winners either offered the highest price for the concession offered or agreed to provide the minimum level of service at the lowest price.

\section{After the Initial Sale}

The initial auction usually resulted in privatization of at least a bare majority ( 51 percent) of the company. During early privatizations of federal electricity assets, the Argentine government retained no more than 39 percent and set aside at least 10 percent for company employees. However, as much as 90 percent of formerly governmentowned companies was sold, with the employees receiving 10 percent of the company and the federal government retaining no ownership. ${ }^{31}$ At least one 1995 sale resulted in the privatization of 98 percent of a relatively small (448 megawatts) hydroelectric company to an Argentine aluminum manufacturer, with the federal government retaining no ownership and only 2 percent retained for the generator's employees. ${ }^{32}$

The shares retained by the Argentine government during the initial sale/privatization could be sold later. Depending on how successfully winners of the initial sale operate the privatized company, the value of the government shares may change. However, sometimes the average price hardly changed. For example, in the case of the privatization of the southern distribution company of greater Buenos Aires, $\$ 511$ million was paid for a 51-percent share in 1992 by a consortium. ${ }^{33}$ The federal government's 39-percent share retained after the initial sale was sold in December 1995 for $\$ 390$ million, ${ }^{34}$ essentially the same per-share price as in the 1992 sale.

\section{The Creation of a Competitive Industry}

\section{Privatized Federal Enterprises}

Argentina first restructured the federal electricity companies, and the electricity industry in general, and then privatized them. The restructuring began in 1992 with the creation of a national regulatory body, ${ }^{35}$ Enre, for the soon-to-be privatized Argentine electricity industry. Also during 1992 a national electricity wholesale market ${ }^{36}$ was organized and the privatization of companies began, within the new rules established by the various treaties and privatization laws discussed earlier. The first three of the federally-owned electricity companies that were privatized produced a total of about 80 percent of the nation's supply of electricity. ${ }^{37}$ The companies were Segba, Ayee, and Hidronor.

Segba. The first of the federal companies privatized was Segba, which served the greater Buenos Aires area, including the city of La Plata. ${ }^{38}$ (Buenos Aires accounts for one-third of Argentina's total population.) Before Segba was privatized it was restructured by separating it vertically, and, to a lesser extent, horizontally. First, power generation was separated from transmission and distribution. Then, the constituent power generation facilities were separated from one another resulting in six separate companies (Figure 14).

Power transmission and distribution also were separated. The transmission assets were combined with those of Ayee and Hidronor to create a single high-voltage transmission company and six regional transmission companies (Figure 15). The distribution assets of Segba were separated into three companies, one each serving northern Buenos Aires, southern Buenos Aires, and La Plata (Figure 16). 
Figure 14. Argentine Federal Electricity Restructuring of Conventional Power Generation

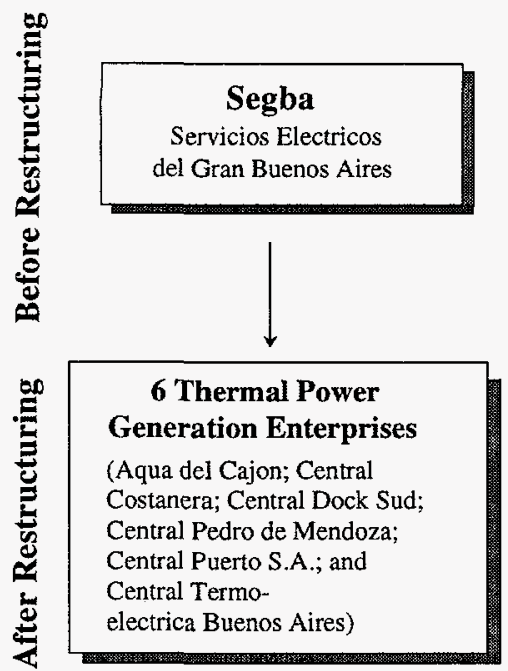

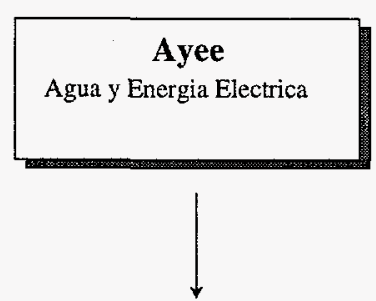

22 Thermal Power Generation Enterprises

(Agua del Toro; Cabra Corral; Central Alto Valle; Central Guemes; Central Sorrento; Central San

Nicolas; Centrales Termicas del Noreste Argentino; Central Termicas Patagonicas, S.A; el Cadillal; el Tigre; Escaba, Fataluefu; Florentino Ameghino; Los Reyunos Pueblo Viejo; Rio Grande; Rio Reyes; Sociedad del Estado; Ullum.)

4 Hydroelectric Generation Enterprises

(Hidroelectrica Ameghino;

Hidroelectrica Arroyito;

Hidroelectrica Diamante; and

Hidroelectrica Los Nihuiles.)

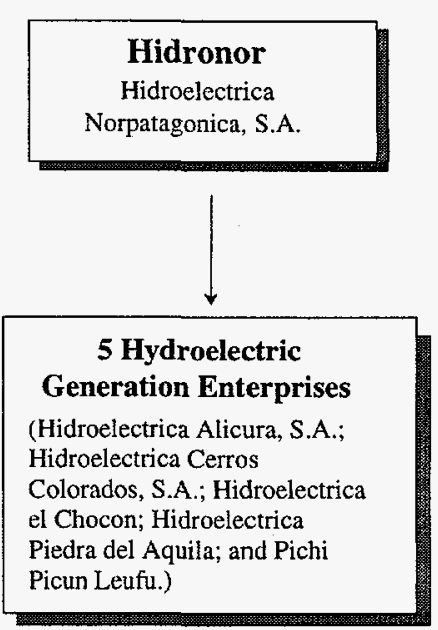

Hidroelectrica

Norpatagonica, S.A.

Figure 15. Argentine Federal Electricity Restructuring of Power Transmission

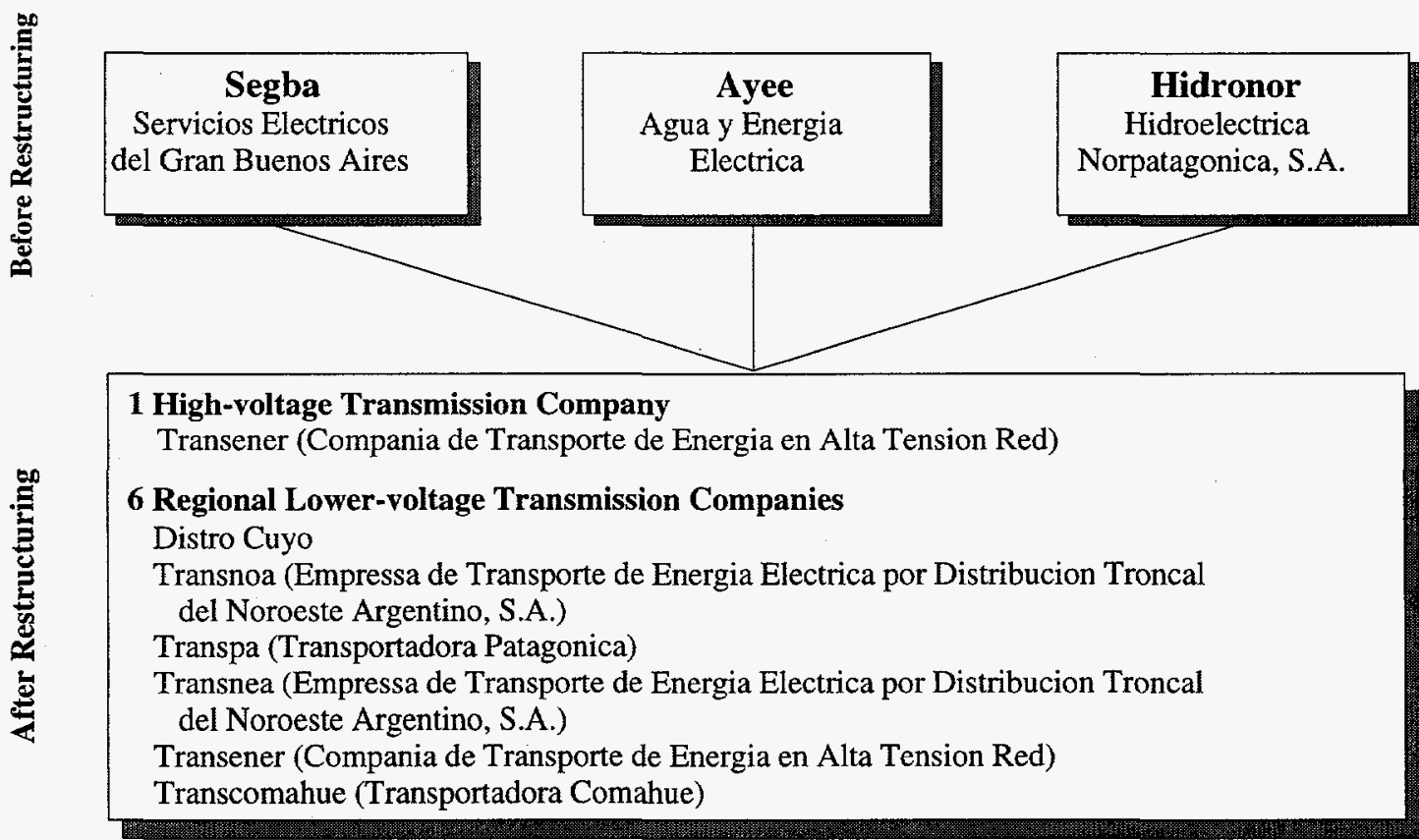


Figure 16. Argentine Electricity Restructuring of Power Distribution

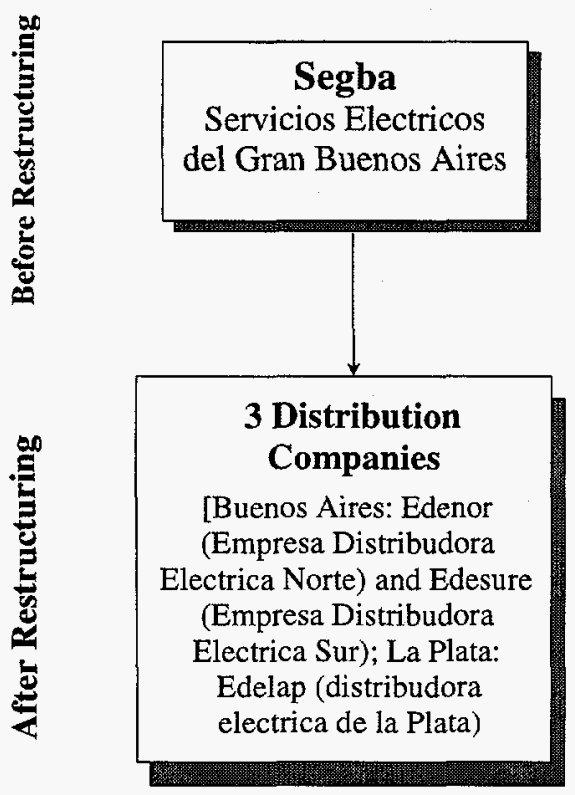

Privatization of Segba's components began during 1992. The first sales were Segba's power generators. Of these, the first sold was Central Puerto in April 1992. Central Costanera and Central Alto Valle were next, in May and August 1992, respectively. Next to be sold were the distribution companies formed from Segba. The two distribution companies serving northern and southern greater Buenos Aires were sold in September 1992. ${ }^{39}$ Subsequently, the remaining three power generation companies, the remaining distribution company, and the high-voltage transmission company, Transener, were privatized.

One interesting aside concerning the privatization of Transener, the high-voltage transmission company, is that National Grid Group, PLC was one of the members of a consortium that purchased a 95-year concession for 65 percent of Transener. ${ }^{40}$ National Grid Group, PLC operates the transmission grid in the United Kingdom.

Ayee. The second of the federal electricity companies privatized had generation and transmission assets nationwide (i.e., everywhere but the Buenos Aires/La Plata metropolitan area). ${ }^{41}$ Because of the large area for which Ayee was responsible, its restructuring resulted in many more individual companies than the restructuring of Segba, but affected substantially fewer electricity customers in total.

The restructuring of Ayee also separated the stages of power generation and transmission, and divided the generation facilities from one another. A total of 12 generation companies were created from the former federal utility (Figure 14). As previously mentioned, the transmission assets of Ayee were combined with those of Segba and Hidronor, creating a total of six transmission companies (Figure 15). ${ }^{42}$

As with Segba, the first assets of Ayee privatized were power generators. The first privatized was the thermal generator Central Termica Guemes in September 1992. ${ }^{43}$ Subsequently, nine additional thermal generators and two hydroelectric generators were privatized.

Hidronor. The final privatization of the federal electricity companies involved Hidronor, which oversaw several hydroelectric power generation in southern Argentina. ${ }^{44}$ Hidronor's primary assets were its four hydroelectric power facilities, each of which was restructured into a separate company and then privatized (Figure 14). Again, the transmission assets of Hidronor were combined with those of Segba and Ayee (Figure 15).

The first privatized was Central Hidroelectrica Alicura, S.A. in August 1993. Also privatized in August 1993 were Cerros Colorados and Chocon. By December 1993, the fourth and final generation company, del Aguila, was privatized.

\section{Nuclear, Binational, and Provincial Enterprises}

Although still not privatized, nuclear electricity assets were restructured in July 1994. The federal government separated the functions of the original nuclear agency into three distinct entities (Figure 17). The first is a company that the Argentine government wishes to privatize. It includes two operational nuclear generation plants, along with one plant still under construction. The second is the nuclear regulatory agency, which will continue to be government-owned and will regulate the individual nuclear powerplants after the plants are privatized. The third is the Argentine federal nuclear research organization, which retained the name of the original nuclear agency and will remain government-owned.

Also still unprivatized are Argentina's two binational hydroelectric generation facilities. One is jointly owned with Uruguay (Salto Grande), and the other is jointly owned with Paraguay and is still under construction (Yacyreta).

Following the onset of privatization of federally-owned electricity companies, restructuring of the provincial electricity companies began. Nearly all distribution assets outside Segba's service area (Buenos Aires and La Plata) belong to these companies. However as of early 1997, 


\section{Figure 17. Argentine Electricity Restructuring of the Federal Nuclear Agency}

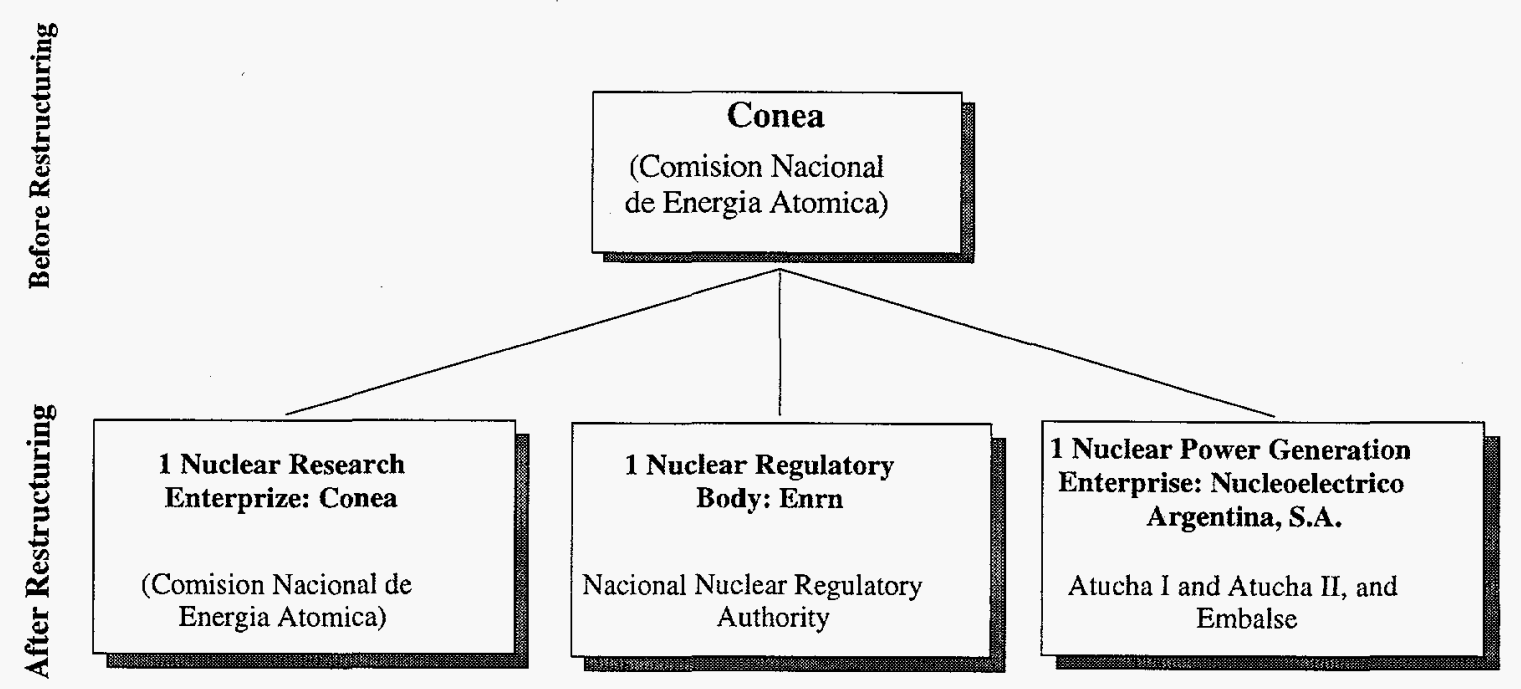

relatively few of the 19 provincial companies have been privatized. The most prominent of the exceptions is Eseba, the electricity company of the Buenos Aires province, which has been partially privatized. ${ }^{45}$

As with the federal electric companies, Eseba was separated both vertically and horizontally, and two generation companies, one regional transmission company, and three distribution companies were created. However, unlike the federal privatizations, the first provincial companies privatized were distribution companies, not power generators. In April 1997, 95-year concessions for 90 percent of the ownership of each of the three distribution companies $^{46}$ were awarded.7 Since then, privatization temporarily ceased; bids for the two generation companies were unexpectedly low and the governor of Buenos Aires province was advised to delay privatization. At the writing of this report (during the summer of 1997), it is unclear as to whether the privatization of the transmission company, planned for the summer of $1997,{ }^{48}$ will proceed as scheduled.

One apparently unprecedented event occurred during the privatization of Eseba. Among the companies unsuccessfully attempting to buy the distribution companies of Eseba were both of the privatized former-federal distribution companies of Buenos Aires (Edesur and Edenor) and one of the privatized former-federal power generators, Central Costanera. ${ }^{49}$ The Atlantic region concession was awarded for $\$ 404$ million to a consortium of United Utilities International (a UK company, which is the parent of the regional electric company Norweb), Camuzzi (an Italian natural gas company), and Loma Negra (Argentina's largest cement manufacturer). ${ }^{50}$ A con- sortium of AES Corp and Community Energy Alternatives (both U.S. companies) won the concessions for the northern and southern areas of the province, paying $\$ 565$ million. ${ }^{51}$ Apparently, there was little concern with possible problems arising from increasing the concentration of Argentine power distribution, should Edesur or Edenor have won any of the three provincial distribution concessions.

\section{The Structure and Regulation of Industry Segments}

As implied by the foregoing discussion of the restructuring and privatization of Argentina's electricity industry, much has changed in the past five years. Therefore, it is useful to provide an overview the current state of the different sectors of Argentina's electricity industry, beginning with a brief discussion of the federal regulatory body, Enre. ${ }^{52}$

The regulatory structure of Argentina's electricity industry was guided by earlier efforts by Chile and the United Kingdom. The federal regulator of Argentine electricity is Enre, which regulates all stages of the electricity industry, but most extensively transmission and distribution. Enre mediates disputes between electricity companies and enforces federal laws, regulations, and terms of concessions. ${ }^{53}$ Enre also establishes service standards that distribution companies must meet and sets the maximum price that transmission and distribution companies may charge for their services. (This type of regulation is known as "price-cap regulation." See the section entitled "RPI-X: Price Caps Versus Rate of Return Regulation" in Chapter 2). Enre oversees the operator of 
the wholesale electricity market, Cammesa, and the generation companies. However, the generation companies are not subjected to price-cap regulation.

The post-privatization Argentine electricity industry consists of conventional power generation, transmission, distribution, and large users. Each of these is discussed in the following sections.

Power Generation. Conventional electricity (thermal and hydroelectric) facilities were sold separately, essentially making each privatized generation facility an independent power producer. The thermal generation facilities were sold outright, while concessions (averaging 30 years) were awarded for the hydroelectric plants. ${ }^{54}$ The majority of Argentina's privatized generation capacity was purchased by foreign companies. Because foreign companies generally showed little interest in small capacity generation facilities, these privatized facilities tended to be exclusively owned by domestic companies. Also, these domestic companies tended not to purchase generation facilities in order to sell electricity in the national wholesale market. Rather, the generation facilities were intended to be captive facilities, purchased to provide for the companies' own electricity needs. For example, two Argentine companies, a paper manufacturer and a steel producer, bought a 20-megawatt oil and gas-fired generating plant for $\$ 8.5$ million..$^{55}$

The post-privatization Argentine power generation industry (including both conventional and non- conventional power facilities) is composed of independent, largely unregulated power generation companies. The companies are essentially unregulated because electric power generation is considered a competitive market. The nearly 40 generating companies operating in Argentina (Figure 14) are assured by the national electricity regullatory body (Enre) of having open and equal access to the national grid $^{56}$ and receive unregulated prices (Argentine electricity prices are discussed below). Nonetheless, some restrictions have been placed on power generators. In order to avoid market concentration difficulties, generation companies are legally restricted to a market share of 10 percent or less of the national electricity sales volume. ${ }^{57}$ They also are prohibited from owning majority shares in electricity transmission facilities. ${ }^{58}$

About ten power generators (including both conventional and non-conventional) are still owned by the federal or provincial governments (in addition to those under construction or in the planning stage), either because efforts to privatize have not begun or because efforts are still unsuccessful. Nuclear power plants and the binational hydroelectric power generation facilities have been more problematic. (See the boxes entitled "Privatization of Argentine Nuclear Generation: The Long Good-bye" and "Privatization of Binational Generation: Twice the Usual Number of Headaches" for discussions of each.)

Even though still state-owned, the companies yet to be privatized effectively act as independent power producers, selling the power they generate through the wholesale electricity market. (Any power they generate is always dispatched.) Additional power demand is met by dispatching power from thermal power generators and cogenerators, in reverse order of their marginal cost of generation.

Generation companies receive income from providing actual electricity and reserve capacity to the transmission network. All generators whose power is dispatched by Cammesa receive a price equal to the marginal cost of the last generator whose power is dispatched. Generators whose production costs are too high to be dispatched by Cammesa receive a payment for providing the system with reserve power. The payment is based on the power they agree to provide, effectively creating a price floor for generators. However, the reserve payment is sufficiently low that generators have a dual incentive to reduce their costs - foremost, to have their electricity dispatched and, second, to increase the difference between electricity production costs and revenues from sales.

Wholesale Electricity Market. The wholesale electricity market (also known as a power pool) has both a supply side and a demand side. The supply side of the wholesale electricity market is composed of independent power producers, privatized generators, generators still owned by the federal government (including the two nuclear power plants), the two binational hydroelectric power plants (also still not privatized), and foreign producers selling imported electricity. The demand side of the wholesale market is composed of distribution companies, large users, and foreign consumers purchasing exported electricity.

The interaction of the supply and demand sides of the wholesale market largely determines wholesale prices for electricity. Additionally, a fixed charge is added to all of the market-determined prices to cover payments made by Cammesa to power generators providing reserve capacity to the electricity grid. Three kinds of wholesale electricity prices exist in the Argentine electricity industry: contractual prices, seasonal prices, and spot prices. Of these, seasonal and spot prices are determined directly in the wholesale market, while contractual prices are affected indirectly by the wholesale market. (Prices are discussed in a separate section below.) 


\section{Privatization of Argentine Nuclear Power Generation: The Long Good Bye}

Argentine Executive Order 1540/94 combined the two operating nuclear facilities (Atucha I and Embalse de rio Tercero) and the under-construction (Atucha II) plant into a newly-created state-owned nuclear power company for the purpose of subsequently privatizing all three plants. " According to a former president of the nuclear agency, the basic reason that Argentina intends to privatize its nuclear generators is, "to finish Atucha II."

The major attraction of the Argentine nuclear plants is Embalse (648-megawatts capacity), which is in the province of Cordoba. Embalse was put into service 10 years later and produces electricity more efficiently than Atucha I.

Privatizing the Argentine nuclear plants together instead of separately presents two major sets of problems from the standpoint of potential buyers: the amount of new investment spending required of the winner of the concession and the amount of risk the winner of the concession must undertake.

Most new investment spending will be for Atucha I and II. Atucha II (750 megawatt capacity), which began in 1981, is 88 -percent complete after $\$ 2$ billion of spending. Completion and activation is expected to require an additional $\$ 700$ million. $^{d}$

The extensive repairs and upgrades to Atucha I (335 megawatt capacity) are another requirement for new investment spending. Atucha I was put into service in 1974 and around $\$ 140$ million is needed to make the necessary upgrade and repairs. Complicating this situation is the unusual design of the plant. Atucha I was designed by Siemens of Germany to meet Argentina's requirements for a heavy-water plant fueled by natural uranium, instead of the more commonly used enriched uranium fuel. The natural uranium technology is little known outside Argentina. ${ }^{\circledR}$

Allocating the risks associated with the operation and decommissioning of the nuclear plants may present a greater problem for potential bidders than the required investment spending. Potential bidders for the plants are unwilling to accept open-ended risk. However, it will be politically difficult for the Argentine government to provide substantial risk guarantees. ${ }^{e}$

The currently proposed legislation to privatize Argentina's nuclear electricity requires the private operator to purchase sufficient insurance to pay up to $\$ 80$ million for nuclear accidents, with Argentina paying all additional costs. The operator would make payments to a fund to cover anticipated future decommissioning costs. Additional decommissioning costs from technological or legislative changes would be paid by the state.

Little movement toward privatization has occurred since June 1996, when agreement was reached with regional representatives concerning nuclear waste disposal. The government also agreed to retain at least one share in excess of 20-percent ownership of the plants. ${ }^{9}$

auNuclear Privatization Progresses in Argentina," Nuclear News (July 1996), p. 38.

'David Pilling, "The Americas: Argentina Plans Nuclear Industry Sell-off," Financial Times (July 5, 1996$),$ p. 5.

"World Bank issues a warning; It May Not Be a Good Idea to Sell off Customs Service," Latin America Regional Reports: Southern Cone (April 15, 1997), p. 6.

'Atucha 1 was built to Argentina's specification because of international concerns regarding the expansion of nuclear technology, because of weapons implications, and because using natural uranium saved Argentina the costs of enriching their uranium. See David Pilling, "The Americas: Argentina Plans Nuclear Industry Sell-off," Financial Times (July 5, 1996), p. 5.

"Argentina Privatization Legislation Being Prepared," Latin American Law and Business Report, Volume 3 , Number 10 (October 31, 1995).

'Mark Hibbs, "Siemens Restructures Nuclear Side Following Market Price Cuts," Nucleonics Week, Volume 38, Number 3 (January 16, 1997), p. 1.

"Argentina Investment: Power Privatisations Run Into Opposition," EIU ViewsWire (September 6, 1996).

Use of the wholesale electricity market has increased substantially since its creation in 1992. For example, the number of exchanges taking place in the market has increased from approximately 20 (between February and April 1994) to around 450 (between November 1995 and January 1996). ${ }^{59}$ The number of participants in the wholesale market has demonstrated similar growth over the same period, particularly by large users, as total participants increased from about 50 (between February and April 1994) to more than 500 (between November 1995 and January 1996). ${ }^{60}$

The wholesale market is administered by Cammesa, a nonprofit, independent operating agency jointly owned 


\section{Privatization of Binational Generation: Twice the Usual Number of Headaches}

Although Argentina still intends to privatize its nuclear power generation assets, it appears that, at least temporarily, the federal government has abandoned its attempts to privatize its share of each of two huge binational hydroelectric facilities. The two facilities are Salto Grande and Yacyreta. The former is a joint venture between Argentina and Uruguay, while the latter is a joint venture between Argentina and Paraguay.

Salto Grande is the older plant, having become fully operational in 1979 , with a capacity of about 1,800 megawatts. The facility is situated on the Uruguay River, which separates northeastern Argentina from Uruguay. Almost 40 years after Uruguay and Argentina agreed in principle to build the plant, it finally became fully operational. Thus, given the beginnings of Salto Grande, it is not surprising that the two countries are experiencing difficulties in reaching an agreement concerning the privatization of the facility.

Yacyreta is substantially newer than Salto Grande. Construction on the Yacyreta facility began 20 years ${ }^{\mathrm{a}}$ before the first of its 20 turbines was brought on-line in September 1994. Less than a year later an additional four turbines were operational. ${ }^{b}$

Despite the differences in the two facilities, many of the same problems must be overcome in order to privatize either. For example, before either facility can be privatized, the Argentine Congress must approve the privatization of Argentina's share of the joint venture. Additionally, the approval of the congress of the venture partner must be received before the entire facility can be privatized. ${ }^{c}$ Argentine Congressional approval of the sale of the binational plants has been withheld at least partially because the proposed 30-year contracts appear too long and allow the concessionaire too much freedom to export the power generated. Potential bidders for the concession for Salto Grande or Yacyreta (if the process proceeds) may have second thoughts about dealing with two sets of governments. ${ }^{d}$

Despite the problems, foreign investment in the binational hydroelectric projects eventually may occur. As recently as January 1996, Ontario Hydro International (a Canadian company) and AES Energy (a U.S. company) met with Argentine government officials about Yacyreta. Argentine officials also met with other private developers around the same time. ${ }^{e}$ However, although foreign interest in the binational projects appears to exist, occasional disparaging public comments (such as Argentina's President Menem characterizing Yacyreta as "a monument to corruption,") do not make the outlook bright.

a“Argentine Government Reveals Large Hydro Plant Plan by U.S. Consortium," Independent Power Report (April 19, 1996), p. 12.

'Uriel Federico O'Farrell, "Energy Sector Legal Update," Latin American Law and Business Report, Volume 3; Number 9 (September 30, 1995).

'Salto Grande has an additional complication in this regard. Because the facility provides much electricity to the nearby Argentine province of Salto Grande, the approval of the province appears necessary to the successful privatization of Argentina's of the facility. See"Argentina Investment: Power, Energy Companies Readied For Sale," ElU ViewsWire (April 9, 1996).

da'Argentine Government Reveals Large Hydro Plant Plan by U.S. Consortium," Independent Power Report (April 19, 1996), p. 12.

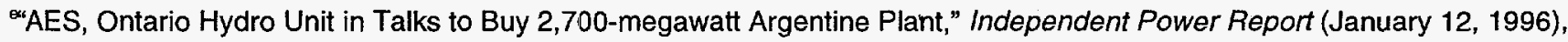
p. 13.

${ }^{f}$ The president's comments appear warranted, given the 20 years and $\$ 8$ billion expended during construction, with an estimated $\$ 4$ billion to complete the plant. See "Argentine Government Reveals Large Hydro Plant Plan by U.S. Consortium," Independent Power Report (April 19, 1996), p. 12.

wholesale by the government and the power generation companies. Cammesa is directed by a board composed of two representatives from each of the following: Argentina's federal government, power generators, transmission companies, distribution companies, and large users. The board of directors makes decisions based on simple majority rule. (However, the president of the board of directors is the Secretary of Energy, who has veto power over board decisions and apparently can be overridden only by the President of Argentina.) Cammesa has three primary tasks: dispatching power; determining the fixed charges and other fixed fees added to spot, seasonal, and contractual prices to cover the full costs of transmission; and ensuring that the power system maintains adequate reserve capacity.

Power is dispatched to the national electricity grid by Cammesa. Cammesa determines the cost of generation for each producer and then dispatches electricity to the transmission grid (discussed in the following section), sending the cheapest power first until current demand has been satisfied. ${ }^{61}$ The price that is paid to each generator 
is determined largely by the highest cost producer whose power is dispatched. ${ }^{62}$ (This arrangement is similar to the marginal cost pricing systems employed in the United Kingdom and Australia, discussed in Chapters 2 and 3 of this report.) Revenues to fund Cammesa's operations may be no more than 3.5 percent of the gross revenues generated by the wholesale electricity market.

Power Transmission. Although the wholesale market allows buyers and sellers of electricity to interact and determine prices, it is the transmission network of Argentina that physically links the buyers and sellers of electricity to one another, delivering power to distribution companies and to large industrial users. The transmission network has two parts, one high-voltage (500 kilovolts) transmission system, and six lower-voltage (220 kilovolts) regional transmission systems.

As in the United Kingdom and Australia, electricity transmission has been defined by Enre (the national electricity regulator) as a natural monopoly and is closely regulated. Firms may enter the industry only after successfully bidding for a fixed-duration concession for a particular area and may charge no more than regulated prices for their services. Concessionaires are required to allow open access to their transmission network to third parties.

Transmission companies are not allowed to buy or sell electricity. Instead, their revenues come exclusively from the regulated prices they receive. The price is based on the availability (providing a fixed source of income) and the use (providing a variable source of income) of their network assets. ${ }^{63}$ The rate at which they are paid is capped by the federal electricity regulatory body, providing an incentive for Argentine transmission companies to reduce their costs. ${ }^{64}$ (Price-cap regulation also is employed in the United Kingdom and Australia.)

The lower-voltage, regional transmission systems transmit power to and from the high-voltage transmission system. Transener ${ }^{65}$ owns and operates the high-voltage segment of the Argentine transmission network (in addition to one of the lower-voltage, regional systems). Transener serves a total 14 of Argentina's 24 provinces, possibly carrying 90 percent of Argentina's transmitted power. ${ }^{66}$ Thus, Transener is considered the primary electricity transmission company in Argentina.

Among the six transmission companies, more than half have been at least partially privatized. The privatized companies are Distro Cuyo, Transnea, Transener, and Transpa ${ }^{67}$ The creation of a seventh private regional company was approved by the Argentine national electricity regulatory body during 1996 . The company will con- struct, operate, and maintain transmission lines and transformer stations associated with the binational Yacyreta hydroelectric plant. ${ }^{68}$ Construction of two additional transmission lines is under consideration and bids have been solicited. One will connect Salto to the Chilean border $^{69}$ and the other will add a fourth transmission line from Patagonia to Buenos Aires. ${ }^{70}$

Power Distribution. The final stage through which electricity passes between creation and use is the distribution stage. In Argentina electricity distribution is defined as a natural monopoly within the geographic area for which a concession is awarded. Firms may enter distribution only after successfully bidding for a concession. Distribution concessions are 95 years in length. ${ }^{71}$ As with transmission companies, distribution companies have regulated maximum rates that they may charge for their services and must allow open access to their distribution network to third parties. ${ }^{72}$

Distribution companies provide power to their end users at rates that are capped by regulators (similar to provisions in the United Kingdom and Australia, discussed in the section entitled "RPI-X: Price Caps Versus Rate-ofReturn Regulation" in Chapter 2). Incentives to reduce operating costs are provided by price-cap regulation, and the benefits of cost reductions are received by the regulated company and its stockholders. Customers, too, eventually save from lower operating costs because the cap is reset every five to eight years. ${ }^{73}$

Distribution assets formerly owned by federal electric utility companies generally were privatized or transferred to the provinces, ${ }^{74}$ which have begun to privatize the distribution operations. Several distribution companies were created by the restructuring. The two largest, which serve greater Buenos Aires, were the first privatized.

Large Users. Large users (who consume at least 2 megawatt hours of electricity annually) may choose to be supplied by the distribution company serving their area or purchase electricity directly from a generation company. Large users are in one of two categories: major, which consume at least 4,380 megawatt hours of electricity annually, and minor, which consume less than 4,380 megawatt hours annually.

Large users choosing to be supplied directly by a generation company pay a contracted price determined through bilateral negotiation with a generation company. Large users who instead choose to be supplied by a distribution company pay the same rate charged any other customer of the distribution company. Large users additionally are permitted to buy power directly from the wholesale electricity market, paying the spot price. ${ }^{75}$ The 
number of large users active in the wholesale electricity market has increased from about 5 in 1993 (none during 1992) to more than 200 in early $1996 .^{76}$

\section{Electricity Prices}

Contractual Prices. Contractual prices are negotiated between generation companies and distribution companies, or between generation companies and large users. The length of the contracts is typically one year. These prices are largely unregulated. Hydroelectric generators may contract only up to 70 percent of their anticipated monthly production. (Note that weather conditions and other factors may dramatically affect water levels and, therefore, the generation capacity of hydroelectric generators.) Similarly, thermal generators may not contract for more delivered electricity than their net generation capacity (some electricity use occurs at the generation facility). ${ }^{\pi}$

Seasonal Prices. Seasonal prices are determined by Cammesa in the seasonal component of the wholesale electricity market and officially maintained for 6-month periods, beginning May 1 and November 1 of each year. The seasons are based on water level ${ }^{78}$ and generally correspond to winter/spring and summer/fall, respectively. Every 3 months Cammesa receives updates to the information it uses to determine seasonal prices and may then revise the current seasonal price. ${ }^{79}$ Thus, seasonal prices are effectively 3 -month prices.

Cammesa sets seasonal prices by using information provided by distribution, transmission, and generation companies. The information includes demand forecasts for typical days, unavailable reactive power, and weekly load curves from distribution companies; availability, restrictions, reactive power equipment unavailable, and net equipment information from transmission companies; capacity, efficiency, planned maintenance, internal electricity consumption, and availability from all generation companies; fuel use and prices from thermal generation companies; and historical and predicted water flows and other characteristics of the reservoirs from hydroelectric generation companies. ${ }^{80}$

The seasonal price is paid by distribution companies purchasing power in excess of the amount they had contracted to purchase from power generators. Seasonal prices during the winter/spring presume that hydroelectric generators are the primary source of power and have lower seasonal prices than the summer/fall period. Alternatively, seasonal prices during the summer/fall presume that thermal generators are the largest source of power and have relatively higher prices. ${ }^{81}$
Spot Prices. Spot prices are determined by the interaction of buyers and sellers in the spot component of the wholesale electricity market. Spot prices vary hourly. ${ }^{82}$ The buyers who pay the spot price include generators and large users. Generators buy electricity they contractually agreed to provide in excess of actual generation. Additionally, large users who contracted for too little power to cover their current need may purchase additional electricity in the wholesale market, paying the spot price.

Sellers receive the spot price and may include distribution companies, generators, and large users. Distribution companies contracting for more electricity than actually purchased by their customers may sell their excess electricity in the spot market. Similarly, generators may sell electricity produced beyond their contractual obligations (to either distribution companies or large users) in the spot market. Large users, too, may sell any electricity they have contracted to buy that exceeds their current use, receiving the spot price.

Spot prices received are adjusted through application of fixed charges. These charges are assessed by Cammesa and are to cover the costs of ensuring some minimum level of reserve capacity and coverage of transmission and other losses.

Reserve capacity provided by thermal generators is based on the level of undispatched, but available, capacity they provide. Hydroelectric generators are paid on the basis of the amount of power generated. Reserve capacity is assigned on the basis of least-cost generation.

Transmission loss charges are based on the physical distance of the electricity seller from Buenos Aires. The greater the distance, the more the price received is discounted to cover transmission losses. ${ }^{83}$

As of May 1996, the base price paid for electricity dispatched by Cammesa was $\$ 5$ per megawatt hour and the fee paid for reserve capacity also was $\$ 5$ per megawatt hour, summing to $\$ 10$ per megawatt hour. ${ }^{84}$

\section{Electricity Sector Effects}

Argentina created a wholesale market for bulk electricity sales in which prices are based largely on the interaction of the two sides of the market, sellers and buyers. The wholesale market is overseen by Cammesa, while Enre, the federal electricity regulatory agency, oversees the electricity industry as a whole. Enre established regulations mandating services that distribution companies must provide to end users and instituted price-cap regulation of transmission and distribution. Price-cap regulation is not applied to generation. The Argentine 
federal government continues to engage in power planning, granting concessions, and setting overall electricity policies. Since privatization, many noticeable changes have marked the Argentine electricity industry. The changes include lower prices, increased reliability, lower employment, higher productivity, and increased foreign investment.

Lower Prices and Increased Reliability. Following privatization, Argentine wholesale electricity prices fell about 60 percent from the pre-privatization level of $\$ 60$ per megawatt hour in August $1992 .{ }^{85}$ As of 1997, Argentina's wholesale power rates stabilized at about 40 percent below the pre-privatization level. However, this occurred only after a period of adjustment, during which wholesale rates fell almost to zero. ${ }^{86}$

Increased reliability of electricity service has been substantial in some cases. For example, the northern Buenos Aires distribution company reduced outages from 22 hours per year in 1992 to 6 hours per year in 1995 . Meanwhile, the southern Buenos Aires distribution company cut outages from 39 hours per year to 6 hours per year over the same period. ${ }^{87}$

Reliability also has been increased through the introduction of improved technology. For example, following privatization, incumbent generating plants were retrofitted with power system stabilizers. Once the stabilizers were in place, a system to automatically disconnect generating capacity could be designed. Transmission faults were then less likely to cause widespread outages because the automatic system disconnects as little generating capacity as possible, given the particular transmission fault. $^{88}$

Increased Productivity, Efficiency, and Investment. Increased productivity did not occur overnight in Argentina. Many newly-privatized companies struggled to institute changes and make improvements. For example, the southern distribution company of greater Buenos Aires, one of the first distribution companies privatized, lost $\$ 150$ million in the first 16 months after privatization. A concerted effort to discover and eliminate illegal connections, through which much electricity was stolen from the company, was eventually successful and the amount of Argentine electricity stolen through illegal connections was substantially reduced. This reduction at least partially accounts for an approximate profit of $\$ 60$ million during $1995 .{ }^{89}$

As productivity at the generation stage was increased, overall efficiency eventually was increased. For example, 30 percent of the capacity of Costanera, a generator near
Buenos Aires, typically was available before privatization. By 1994, availability was increased to 75 percent. Similarly, the electric distribution company serving the city of La Plata increased its customer base from 228,000 to 270,000 customers between 1992 and 1995, even while company employment fell..$^{90}$

Electricity service to Buenos Aires will be increased with the construction of a new $\$ 250$ million transmission line from Patagonia to Buenos Aires. The transmission line will be commissioned by a consortium ${ }^{91}$ of eight privatized electricity generation companies. The companies are legally prohibited from holding a majority share in the planned transmission line, but will fund the construction and award the concession. The consortium also plans a $\$ 25-$ million capacitor project, which is expected to substantially increase the electricity supply to the greater Buenos Aires area from 2,700 megawatts to 4,600 over a three-year period. The consortium members currently produce 31 percent of Argentina's total electricity supply. ${ }^{92}$

With increased productivity, unemployment has become a problem as individual electricity companies in Argentina (and Chile) have reduced their total employment by as much as 40 percent since privatization. ${ }^{93}$ Further, rising economy-wide unemployment prompted the 1994 signing of an agreement between the Argentine federal government, business organizations, and labor unions to restrain unemployment. This agreement includes the creation of training programs for displaced workers. ${ }^{94}$

Increasing foreign investment was one of the primary reasons the Argentine government undertook the 1992 round of general privatization. The government has indicated satisfaction with the level of foreign investment since privatization began (Figure 18). For example, the private owners of the northern distribution company of greater Buenos Aires made capital investments of about $\$ 380$ million between September 1992 and 1995. Between 1995 and 2000 an additional total investment of $\$ 500 \mathrm{mil}-$ lion is planned for northern Buenos Aires. ${ }^{95}$ Anticipated economy-wide electricity investment between 1996 and 2001 is $\$ 7$ billion, most of which is attributed to private investors. ${ }^{96}$ The primary purpose of at least some of the anticipated investment is to improve customer service.

\section{Economy-wide Effects}

Debt Reduction. Privatization has reduced Argentina's federal government debt in two ways. First, federal assets were sold and the proceeds were used to retire debt. Privatization resulted in payments to the Argentine federal government of $\$ 10$ billion. ${ }^{97}$ Second, the losses 


\section{Figure 18. Total U.S. Direct Foreign Investment in Argentina, Selected Years}

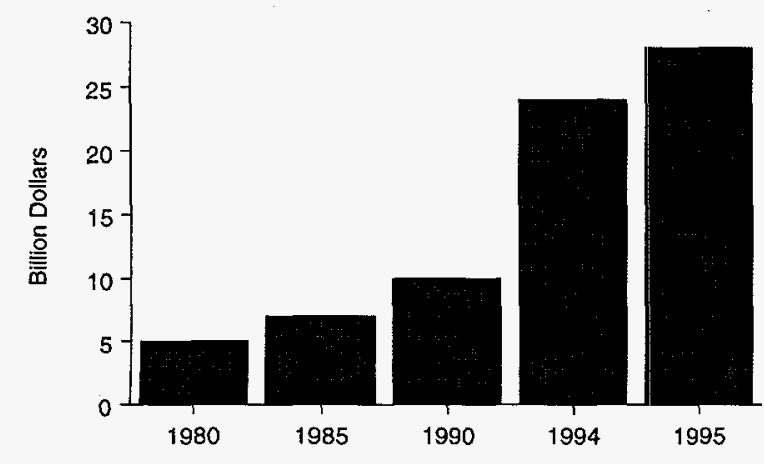

Source: U.S. Department of Commerce, Survey of Current Business, Various issues.

generated by many federal companies were eliminated by selling the companies, thus ending the drain on the federal treasury as additional savings from reduced government subsidies to public companies were anticipated. ${ }^{98}$

There was a concern that some Argentine federal electricity companies might have drawn unacceptably low bids. As a result, in order to ensure their sale, the Argentine federal government agreed to retain some of these companies' liabilities and debt. (This type of partial assumption of the debt of federal companies in order to ensure their sale was applied to federal assets of many Argentine industries, not just the electricity industry.) The assumption of these debts (essentially, privatizationrelated expenses) necessarily contributed to Argentina's increase in publicly-guaranteed foreign debt (from $\$ 47.6$ billion in 1991 to an estimated $\$ 62.2$ billion in $1995^{99}$ ) and could lead to the conclusion that privatization worsened Argentina's external debt. However, in reality, Argentina's external debt may have increased substantially more in the absence of their assumption of this debt, due to the anticipated continued losses and debts of the federal companies.

The anticipated long-term effect of privatizing former federal companies in Argentina is reduced federal debt. Between 1990 and 1994, Argentine government foreign debt was reduced by $\$ 15$ billion as a result of proceeds from direct sale of federal assets. ${ }^{100}$ An additional $\$ 2.7$ billion of debt was transferred (via privatization) by the federal government to the new private owners of the former-federal companies. ${ }^{101}$ Further, the ratio of debt interest payments to exports has fallen from nearly 35 percent in 1991 to an estimate of slightly less than 17 percent in $1995 .^{102}$
Privatization proceeds have been considerable. As a result, the Argentine federal government has been able to substantially reduce domestic borrowing. Other privatization funds are earmarked for the repurchase of government bonds, which also will reduce federal debt.

Employment Reduction. Federal employment in Argentine industries selected for privatization was anticipated, by the completion of privatization, to fall from a pre-1990-level of 222,000 employees to less than 42,000 employees. About 66,000 of those losing their public jobs were expected to be hired by the new private firms and another 19,000 of these employees were expected to retire. ${ }^{103}$ At the same time, slowed economic growth and restructuring of the economy contributed to a soaring Argentine unemployment rate. The unemployment rate increased from 6.8 percent in 1991 to about 13.5 percent in $1995^{104}$ and, through May 1997, was about 17 percent. ${ }^{105,} 106$ However, as of 1993, opposition by organized labor to such traumatic change was limited and was more than offset by public approval and by increased opportunity in the private sector. ${ }^{107}$

Few data are available concerning actual employment changes in privatized companies resulting from Argentina's massive privatization program. It is unclear how closely actual employment changes in the electricity industry have reflected anticipated reductions.

Improved Economic Environment. By almost every measure, Argentina's economy has improved since the 1992 privatization efforts began. One of the first signs of the country's improvement occurred in December 1992, when it was allowed to enter into a credit-enhancing international debt agreement with the United States (generally known as "Brady debt"). ${ }^{108}$ Inflation (measured by the wholesale price index) fell from an annual rate of 1,607 percent in 1990 to 5.9 percent in $1994 .{ }^{109}$ Real investment grew at an annual rate of approximately 20 percent between 1991 and 1994. ${ }^{110}$ Economic growth (measured by the change in real Gross Domestic Product) varied between 5.8 and 8.7 percent between 1991 and $1994,{ }^{111}$ fell to about 1 percent during $1995,{ }^{112}$ but rebounded (by May 1997) to reach a 1997 annualized rate of about 8 percent. ${ }^{113}$

The interaction of supply and demand for electricity will determine the price in the newly-privatized environment. Increased efficiency is expected to reduce costs and put downward pressure on prices. However, real prices after privatization may increase as elimination of the use of government subsidies and ceilings that historically kept prices low may raise some prices. Further, elimination of previously existing cross-subsidies in which rural and large industrial customers subsidized urban residential customers ${ }^{114}$ may also lead to increases in some prices paid for electricity. 
Foreign investment in all Argentine industry has increased, ${ }^{115}$ providing capital needed for the introduction and application of new technologies. According to the Inter-American Development Bank, net capital inflows to Argentina increased each year between 1991 and 1994, reaching almost $\$ 11$ billion in 1994 (with the private sector receiving almost $\$ 9$ billion). ${ }^{116}$

\section{Resulting Foreign Investment}

According to recent information, the largest concentration of private firms in Argentine electricity is in the area of power generation, the first segment of Argentina's electricity industry privatized (Figure 19). However, despite the substantially larger number of privatizations in power generation, electricity distribution based on sales is almost as heavily controlled by private firms (Figure 20).

\section{Figure 19. Ownership of Argentine Electricity Assets, 1995}

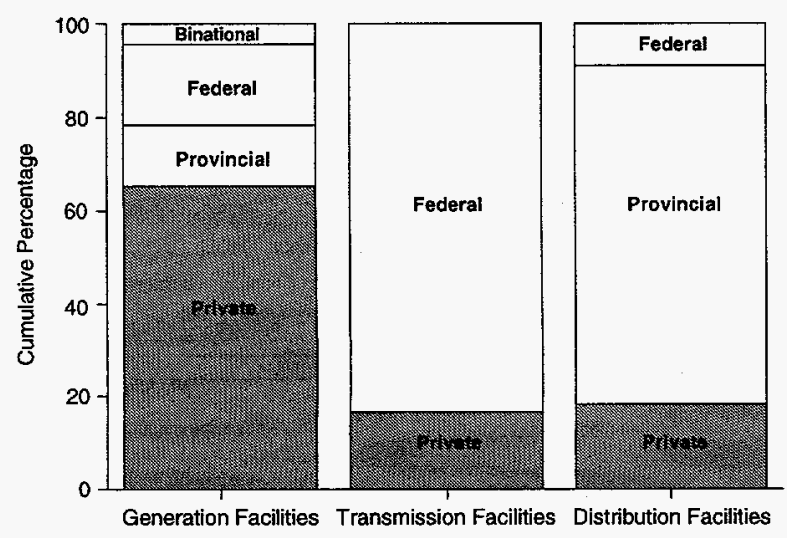

Source: World Power Service, Latin American Report (Eddystone, Pennsylvania: WEFA Group, November 1996)

Nearly all the companies that are investing in Argentina's electricity industry are from the United States or Chile.

The reduced risk associated with the political climate of Argentina, the apparent dedication of the current government to its program of macroeconomic stability, and the large growth rates forecast for Latin America (and for Argentina, in particular) have attracted many companies to participate in the privatization of Argentina's electricity industry. For example, when 90 percent of the Buenos Aires provincial electricity company was privatized during 1996, sixteen consortia made offers. ${ }^{117}$ (A listing of foreign companies with current investments in Argentine electricity is provided in Table 20. See Appendix Table C1 for more information.)
Figure 20. Argentine Electricity Sales Volume Market Shares, 1995

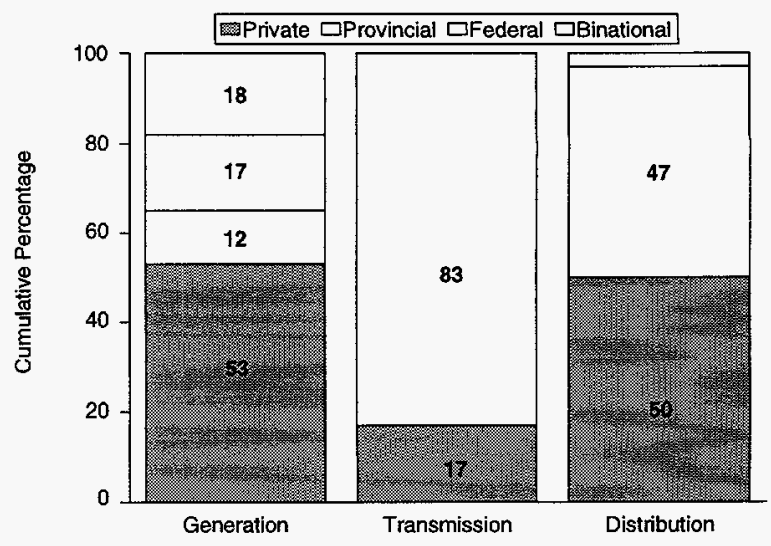

Source: World Power Service, Latin American Report (Eddystone, Pennsylvania: WEFA Group, November 1996).

Private companies have invested in the privatization of Argentina's electricity industry for several reasons. First, there are growth opportunities (the U.S. electricity industry is forecast to grow two percent between 1994 and 2000, while Argentina's electricity industry has been forecast to expand at an average annual rate of 8 percent for the same period). ${ }^{118}$ Second, U.S. companies may see Argentina as a laboratory for learning how to operate in a deregulated market and hope to transfer the knowledge gained to the soon-to-be deregulated U.S. electricity industry. ${ }^{119}$ Third, companies have invested in Argentina's privatized electricity industry in order to be positioned to subsequently expand into investments in the privatized electricity industries of other Latin American countries. ${ }^{120}$ Fourth, some companies have developed specialities in electricity operations (e.g., power generation) and see opportunities to apply those specialities in Argentina. ${ }^{121}$

However, some companies investing in Argentine electricity have made mistakes. Companies have made investments in properties that later were sold. There also have been cases where, by substantially outbidding other companies, buyers have in fact overpaid for properties. ${ }^{122}$ Some companies have reacted to mistakes by others by exercising caution..$^{123}$ Others have decided to refocus their investments to a more narrow range of activities.

Many of the companies investing in Argentina's privatized electricity industry are active in power generation in their own country. ${ }^{124}$ For example, privatization in Argentina has enabled several of Chile's electricity firms to enter power generation in Argentina. 
Table 20. Argentine Electricity Privatization-Related Acquisitions

\begin{tabular}{|c|c|c|}
\hline Argentine Electricity Assets & Acquiring Company (Nationality) & Value \\
\hline Power generation, and power distribution . .......... & AES Corporation (U.S.) & $\$ 771.5$ million* \\
\hline Power generation $\ldots \ldots \ldots \ldots \ldots \ldots \ldots \ldots \ldots$ & Amoco Co. (U.S.) & N. A. \\
\hline Power generation, and power distribution . & Camuzzi Gazometri (Italy) & $\$ 8.6$ million $^{\star}$ \\
\hline Power generation, and power distribution $\ldots \ldots \ldots \ldots$ & Chilectra/Enersis (Chile) & $\$ 119.6$ million \\
\hline Power generation $\ldots \ldots \ldots \ldots \ldots \ldots$ & Chilgener (Chile) & $\$ 162.7$ million \\
\hline Power generation $\ldots \ldots \ldots \ldots \ldots \ldots$ & Chilquinta (Chile) & $\$ 45.4$ million \\
\hline Power generation, and power distribution .... & Cinergy (U.S.) & N. A. \\
\hline Power distribution $\ldots \ldots \ldots \ldots \ldots \ldots \ldots$ & Citicorp Capital Irivestors (U.S.) & $\$ 139$ million ${ }^{\star *}$ \\
\hline Power generation & CMS Energy (U.S.) & $\$ 124.5$ million ${ }^{\star}$ \\
\hline Power distribution & $\begin{array}{l}\text { Community Energy Alternatives/Public } \\
\text { Service Enterprise Group }\end{array}$ & $\$ 188$ million \\
\hline Power generation & Consumers Energy Co. (U.S.) & N. A. \\
\hline Power generation $\ldots \ldots \ldots \ldots \ldots \ldots \ldots \ldots$ & Dominion Resources, Inc., (U.S.) & $\$ 152.7$ million \\
\hline Power generation, and power transmission . . . . . . . . & Duke Power (U.S.) & $\$ 147.1$ million \\
\hline \multirow{2}{*}{$\begin{array}{l}\text { Power generation, power transmission, } \ldots \ldots \ldots \ldots \ldots \ldots \\
\text { and power distribution }\end{array}$} & Electricite de France (France) & $\$ 110.3$ million \\
\hline & EI Paso Electric (U.S.) & $\$ 157$ million \\
\hline Power generation, and power distribution $\ldots \ldots \ldots \ldots \ldots$ & Endesa (Chile) & $\$ 446.1$ million* \\
\hline Power transmission, and power distribution & Endesa (Spain) & $\$ 42.8$ million* \\
\hline Power generation, and power distribution $\ldots \ldots \ldots \ldots \ldots$ & Enersis (Chile) & $\$ 703.5$ million \\
\hline $\begin{array}{l}\text { Power generation, power transmission, } \ldots \ldots \ldots \ldots \ldots \ldots \\
\text { and power distribution }\end{array}$ & Entergy (U.S.) & $\$ 85.1$ million $^{*}$ \\
\hline $\begin{array}{l}\text { Power generation, power transmission, } \ldots \ldots \ldots \ldots \ldots \ldots \\
\text { and power distribution }\end{array}$ & Houston Industries (U.S.) & $\$ 68.2$ million \\
\hline Power distribution & $\begin{array}{l}\text { Hydroelectrica, de Ribagorzana, S.A. } \\
\text { (Spain) }\end{array}$ & $\$ 85.6$ million \\
\hline Power generation & Iberdrola (Spain) & $\$ 17.3$ million \\
\hline Power generation $\ldots \ldots \ldots \ldots \ldots \ldots$ & $\begin{array}{l}\text { Kansas City Power and Light/Western } \\
\text { Resources (U.S.) }\end{array}$ & $\$ 23.4$ million \\
\hline Power generation & LG\&E Energy, Corp. (U.S.) & $\$ 31.3$ million \\
\hline Power generation & Louis Dreyfus Argener, S.A. (U.S.) & $\$ 13.8$ million \\
\hline Power generation & Merrill International, Ltd. (U.S.) & $\$ 100$ million $^{\star \star}$ \\
\hline Power generation $\ldots \ldots \ldots \ldots \ldots \ldots \ldots \ldots \ldots$ & National Electricity Co. of Chile (Chile) & $\$ 600$ million $^{*}$ \\
\hline Power transmission $\ldots \ldots \ldots \ldots \ldots \ldots$ & National Grid, PLC (U.K.) & \\
\hline Power generation $\ldots \ldots \ldots \ldots \ldots \ldots \ldots \ldots \ldots$ & New World Power (U.S.) & N.A. \\
\hline Power generation $\ldots \ldots \ldots \ldots \ldots \ldots \ldots \ldots \ldots$ & Northeast Utilities (U.S.) & $\$ 18$ million* \\
\hline Power generation, and power distribution $\ldots \ldots \ldots \ldots$ & PSI Energy (U.S.) & $\$ 131$ million \\
\hline Power generation $\ldots \ldots \ldots \ldots \ldots \ldots$ & Repsol (Spain) & N.A. \\
\hline Power distribution $\ldots \ldots \ldots \ldots \ldots \ldots \ldots \ldots \ldots$ & Sociedad Austral de Electricidad (Chile) & $\$ 97.8$ million ${ }^{\star *}$ \\
\hline Power distribution $\ldots \ldots \ldots \ldots \ldots \ldots \ldots \ldots$ & $\begin{array}{l}\text { Societe D'Amenagment Urbain et Rural ) } \\
\text { (France) }\end{array}$ & $\$ 42.8$ million \\
\hline Power generation $\ldots \ldots \ldots \ldots \ldots \ldots \ldots \ldots \ldots$ & Southern Co. (U.S.) & $\$ 107.8$ million \\
\hline Power generation $\ldots \ldots \ldots \ldots \ldots \ldots \ldots \ldots$ & TransAlta Energy (Canada) & $\$ 90.4$ million \\
\hline
\end{tabular}

Note: * indicates that the value is a lower boundary on the amount of total investment because the company's contribution was not disclosed for at least one consortium (of which it is a member) that invested in Argentine electricity. ${ }^{\star *}$ indicates that the value is a lower boundary on the amount of total investment because the value of one (or more) of its investments was not disclosed.

Sources: Annual reports to shareholders and various public news sources. 
A network of Latin American transcontinental gas pipelines (permitting the conversion of coal-fired to natural gas-fired electricity plants) is well under way. Some of the firms active in the expansion of the natural gas pipeline network also are electricity companies. Examples include Chilgener ${ }^{125}$ and CMS Energy (a U.S. company). ${ }^{126}$ (See the box entitled "Latin America's New Natural Gas Pipeline Network" for a discussion of the relationship between natural gas pipeline investment and electricity investment in Latin America.)

The success of the network of gas pipelines may enhance the probability of a Latin American electricity grid.
Argentina's electricity privatization has further spurred speculation that the natural gas network under construction will be formally extended, creating a regional electricity/natural gas network. In fact, the chairman of one of these Chilean electricity firms, Chilgener, has publicly speculated that within ten years an interconnected grid for the seven Southern Cone countries (Argentina, Bolivia, Brazil, Chile, Paraguay, Peru, and Uruguay)-with a single multinational regulator ensuring efficient use of capacity-will exist. Such an extraordinary innovation would substantially advance Latin America's standing in world markets. 


\section{Latin America's New Natural Gas Pipeline Network}

Many Latin American countries currently are developing an infrastructure that will facilitate inter-country trade in natural gas, which is expected to fuel future electricity generation investment. One of the problems facing Argentina and other Latin American countries is the antiquated state of existing natural gas transportation assets. This problem may grow more acute, because Latin American natural gas consumption has been predicted to grow as much as four to five percent annually through 2005 , a substantially higher growth rate than the two percent forecast for worldwide gas consumption. ${ }^{\mathrm{a} b}$ (Two primary destinations for proposed and under-construction natural gas pipelines are Brazil and Chile, both of which have substantial air pollution problems, implying that environmental considerations may be involved in the development of the pipeline.)

Nearly $\$ 7$ billion and 6,000 miles of new natural gas pipelines are either under construction or under active consideration. The pipelines will connect natural gas-producing areas in Argentina, Bolivia, Colombia, and Peru with consumers in Brazil and Chile; with electric powerplants in Chile, Peru, and Brazili, ${ }_{1}^{\mathrm{c}}$ and with seaports for export markets. Other projects under consideration will connect Argentina with Paraguay and Uruguay. ${ }^{d}$ These projects offer substantial opportunities for U.S. companies.

Enron, El Paso Energy, and CMS Energy (all U.S. companies) are among international companies involved in Latin American natural gas pipeline projects. ${ }^{\ominus}$ Plans for a $\$ 1.8$-billion, $1,800-$ mile Bolivia/Brazil pipeline $^{t}$ are proceeding despite domestic protests concerning the transport of natural gas from Bolivia to Brazil. ${ }^{9}$ Construction will begin with the approval of the financing of the project, both financial approval and construction are expected during the summer of 1997. ${ }^{\mathrm{h}}$ Enron has a 34-percent share in the Bolivian segment of the pipeline and an 8-percent share in the Brazilian segment.' El Paso Energy holds a 10-percent share in the Brazilian segment of the same project. ${ }^{j}$

CMS Energy is the primary member of a consortium building a $\$ 700$ million, 160 -mile pipeline connecting Argentina and northern Chile. ${ }^{k}$ CMS also owns the largest private share of Argentina's privatized 2,600-mile transportation gas pipeline.'

a"Latin American Gas Industry Poised for Enormous Growth, Industry Overview," Gas Worid International (August, 1994).

'Energy Information Administration, International Energy Outlook 1997, DOE/EIA-0484(95) (Washington, DC, April 1997), pp. 48 and 54.

"Warren True, "World Pipeline Construction Looks to Remain Robust to Century's Turn," Oil and Gas Journal (February 10, 1997), p. 34; David Abramson, "El Paso Energy Pushes Into Latin America in Search of Good Investment Opportunities," The Oil Daily, Volume 47, Number 72 (April 16, 1997), p. 3; and Michael Davis, "Enron Wins Bid for Brazilian Project," The Houston Chronicle (June 17, 1997), p. 1.

${ }^{\mathrm{d}}$ The numerous regional trade accords probably contributed much to the legal and commercial foundations underlying the inter-country natural gas transportation projects. The trade agreements include: the Andes Group, the Southern Cone Common Market (Mercosur), and the Group of Three Amigos. The Andes Group includes Bolivia, Colombia, Ecuador, Peru, and Venezuela; Mercosur includes Argentina, Brazil, Paraguay, and Uruguay; and the Three Amigos includes Colombia, Mexico, and Venezuela.

See "Focus on the Grupo Andino," Latin America Regional Reports (April 20, 1995), p. 4.

"Michael Davis, "Enron Wins Bid for Brazilian Project," The Houston Chronicle (June 17, 1997), p. 1.

'Frank Gray, "Latin America: Regional Dash for Gas," Financial Times (June 19, 1997), p. 4.

Micael Kepp, "Critics' Voices Begin to be Heard on Brazil-Bolivia Gas Line," Platt's Oilgram News (February 21, 1996 ), p. 8.

h"Brazil-Bolivia Pipeline," Privatisation International, Number 102 (March 1, 1997).

'Enron Corp, 1994 Annual Report to Shareholders and Customers, p. 26.

'David Abramson, "El Paso Energy Pushes Into Latin America in Search of Good Investment Opportunities," The Oil Daily, Volume 47, Number 72 (April 16, 1997), p. 3. The 750-mile, $\$ 700$ million Chilean-Argentinean pipeline that was to have been constructed by a consortium led by Tenneco Energy was canceled during the summer of 1996, before El Paso Energy acquired Tenneco Energy. See John Javetski and Jeffrey Ryser, "New Gas Finds, Pipelines Shaping Latin American IPP Environment," Electrical World, Volume 210, Number 9 (September 1996), p. 28.

k"CMS Energy Tries U.S.-style Industrial Incentives to Boost Demand in Argentina," Industrial Energy Bulletin (February 7 , 1997), p. 12; and "Chile to Build Gas Pipeline," The Oil Daily, Volume 47, Number 114 (June 16, 1997 ), p. 6.

I"CMS Energy Introduces Argentina's First Utility-Sponsored Business Expansion Program," PR Newswire (December 11, 1996). 


\section{Endnotes}

I"Getting the government books in order," The Economist (October 12, 1996), U.S. Edition, p. S15.

'Unfortunately, Mexico's currency devaluation of December 1991 had negative ramifications for all of Latin America, including Argentina, an effect termed the "tequila effect." The "tequila effect" caused to a substantial reduction in the level of Argentina's foreign reserve beginning in 1992, severely constricting the country's money supply and was followed by a recession. By 1996, however, the Argentina's economy began to expand ("Getting the government books in order," The Economist (October 12, 1996), U.S. Edition, p. S15.).

${ }^{3}$ Argentina's fiscal reforms included balancing the state public accounts, balancing the budget of the federal government, increasing the revenues collected by the federal government, and reducing some import and export tariffs (Latin American Report, (Baldwyn, Pennsylvania: WEFA Energy World Bank, 1996), p. 2.1.)

${ }^{4}$ Argentina's Privatization Program: Experience, Issues, and Lessons (Washington, DC: The World Bank, 1993), pp. 3-4.)

"These costs are referred to as "X-inefficiency" and were identified by Harvey Leibenstein in "Allocative Efficiency vs. X-efficiency," American Economic Review, Volume 56 (1966), pp. 392-415. Argentina's electricity industry may have substantial X-inefficiency as it produced losses of almost \$1 billion each of the two years before privatization (Argentina's Privatization Program: Experience, Issues, and Lessons (Washington, DC: The World Bank, 1993), pp. 3-4.).

'Argentina's Privatization Program: Experience, Issues, and Lessons (Washington, DC: The World Bank, 1993), pp. 3-4.

PPeter R. Lalor and Hernan Garcia, "Reshaping Power Markets: Lessons from South America," Electricity Journal, Volume 9, Number 2 (March 1996), pp. 63-71.

${ }^{8}$ Jonathan Friedland and Benjamin A. Holden, "Utility Deregulation in Argentina Presages Possible U.S. Upheaval," The Wall Street Journal (June 19, 1996), p. A1.

'R. Peter Lalor and Hernan Garcia, "Reshaping Power Markets: Lessons from South America," Electricity Journal, Volume 9, Number 2 (March 1996), pp. 63-71.

${ }^{10}$ Respectively, these companies were: the aforementioned Segba, Compania de Agua y Energia Electrica (Ayee), Hidroelectrica Norpatagonica S.A. (Hidronor), and the power generation capacity of Commission Nacional de Energia Atomica (Cnea).

${ }^{11}$ Ayee also oversaw Argentina's interests in its joint-venture with Paraguay in the huge Yacyreta hydroelectric plant.

${ }^{12}$ Hidronor also was responsible for development of hydroelectric generation, most of which was in southern Argentina.

${ }^{13}$ Commission Nacional de Energia Atomica (Cnea) was created by Executive Decree Number 1540/94 (Bernardo E. Duggan And Victoria Zoldi, "A Guide to Energy, Natural Resources and Utilities Law: Argentina," International Financial Law Review (April 1996), Supplement pp. 3-7.).

${ }^{14}$ Peter R. Lalor and Hernan Garcia, "Reshaping Power Markets: Lessons from South America," Electricity Journal, Volume 9, Number 2 (March 1996), pp. 63-71.

${ }^{15}$ Jorge Cubas, Sabastiao Mattos, Miguel Moyola, Paul Slocomb, and Tom Studwell, "Latin America," The International Lawyer (Spring 1990).

${ }^{16}$ Public Law 23,696.

${ }^{17}$ Bernardo E. Duggan and Victoria Zoldi, "A Guide to Energy, Natural Resources and Utilities Law: Argentina," International Financial Law Review (April 1996), supplement pp. 3-7.

${ }^{18}$ The electricity company was Servicios Eléctricos del Gran Buenos Aires (Segba), Argentina's Privatization Program: Experience, Issues, and Lessons (Washington, DC,: The World Bank, 1993), pp. 2-3. The names of the privatized companies and their acronyms will generally be relegated to footnotes/endnotes. In so far as possible descriptive terms will be used in this report to reduce the possibility of the reader's becoming lost in the maze created by the large number of similarly-named companies and numerous acronyms.

${ }^{19}$ Among energy industries separate laws were passed for electric power, oil, natural gas, and mining. Bernardo E. Duggan and Victoria Zoldi, "A Guide to Energy, Natural Resources and Utilities Law: Argentina," International Financial Law Review (April 1996), Supplement pp. 3-7.

20" Foreign Investment," http://www.invertir.com/05forei.html (May 15, 1997). Similar agreements are in force with the countries of Austria, Belgium-Luxembourg, Canada, Egypt, France, Germany, Hungary, Italy, Poland, Spain, Sweden, Switzerland, and the United Kingdom. Interestingly, of the countries with investment in Argentina's privatized electricity industry, only Chile, which is a fellow member of Mercosur with Argentina, and Finland don't have a current bilateral trade agreement with Argentina.

${ }^{21}$ Duggan, Bernardo E. and Victoria Zoldi, "A Guide to Energy, Natural Resources and Utilities Law: Argentina," International Financial Law Review (April 1996), supplement pp. 3-7. The importance of pre-privatization restructuring is discussed by Spiller and Martorell. See Pablo T. Spiller and Luis Viana Martorell, "How Should It be Done? Electricity Regulation in Argentina, Brazil, Uruguay, and Chile," International Comparisons of Electricity, Gilbert, Richard J. Gilbert and Edward P. Kahn, eds., (New York: Cambridge University Press, 1996), p. 83.

${ }^{2}$ According to Argentina's then Energy Secretary Bastos, "In reforming [the electricity] sector, we wanted to use the best electricity model worldwide, so we borrowed aspects of the Chilean and British systems ... ." See "Argentina: Ongoing Infrastructure Improvement," Infrastructure Finance (December 1995/January 1996), p. 2.

${ }^{23}$ Public Law 21,382

24،"Foreign Investment," http://www.invertir.com/05forei.html (May 15, 1997).

${ }^{25}$ The World Bank is an international organization that is headquartered in Washington, D.C. of the United States. However, the United States, at least formally, exercises no more control over the World Bank than any other supporting country.

In the World Banks' own words, it is, "[t]he International Bank for Reconstruction and Development, frequently called the "World Bank" [and] was established in July 1944 at the United Nations Monetary and Financial Conference in Bretton Woods, New Hampshire, USA. The World Bank opened for business on June 25, 1946. The World Bank's goal is to reduce poverty and improve living standards by promoting sustainable growth and investments in people. The Bank provides loans, technical assistance and policy guidance to help its developing-country members achieve this objective. The World Bank group of institutions includes: the International Bank for Reconstruction and Development (IBRD), the International Development Association (IDA), the International Finance Corporation (IFC), the Multilateral Investment Guarantee Agency (MIGA), and the International Centre for the Settlement of Investment Disputes (ICSID). See The World Bank, http:/www.worldbank.org/html/extdr/faq/97111.htm\#E19E1 (July 18, 1997). 
${ }^{26}$ It may be instructive to briefly review the World Bank's general steps of privatization. These are: parliamentary approval; establishment of a privatization commission; preparation and approval of regulatory legislation or decrees; contracting technical, legal, and financial consultants; definition of separate business units; labor-restructuring and voluntary retirement schemes; organization of regulatory structure; preparation of bidding documents and transfer contracts; prequalification of potential bidders; issuance of calls to tender; evaluation of bids; preliminary and final awards; company and asset transfer; disposal of minority share holdings; and organization of employee stock ownership programs. See Argentina's Privatization Program: Experience, Issues, and Lessons (Washington, DC: The World Bank, 1993), pp. 2-3.

${ }^{27}$ Argentina's Privatization Program: Experience, Issues, and Lessons (Washington, DC: The World Bank, 1993), p. 5.

${ }^{28}$ Several conditions are important for the creation of competitive and efficient energy markets. Lalor and Garcia enumerate those conditions for electricity markets. The conditions include: a) mandatory separation of regulated functions and clear delineation of the limits of involvement by regulated entities in competitive markets; b) unbundling of transmission charges and provision of "comparable" fair transmission access; c) clearly defined, published nodal or zonal transmission prices reflecting incremental operating and upgrade costs; d) establishment of a centrally-dispatched commodity market, spot markets for both capacity and energy priced at system marginal costs, and a parallel bilateral market based on long-term contracts; and e) access by generators and marketers to at least a part of the retail market. See Peter R. Lalor and Hernan Garcia, "Reshaping Power Markets: Lessons from South America," Electricity Journal, Volume 9, Number 2 (March 1996), pp. 63-71.

${ }^{29}$ Argentina's Privatization Program: Experience, Issues, and Lessons (Washington, DC: The World Bank, 1993), p. 6.

${ }^{30}$ Argentina's Privatization Program: Experience, Issues, and Lessons (Washington, DC: The World Bank, 1993), p. 6.

${ }^{31}$ Argentina Ministry of Economy and Public Works and. Services, http://www.mecon.ar/invest/english/parti2htm (July 1, 1997).

${ }^{32}$ Argentina Ministry of Economy and Public Works and. Services, http://www.mecon.ar/invest/english/patri2h.htm (July 1, 1997).

${ }^{33}$ The consortium is called Distrilec Inversora and includes Perez Companc of Argentina (32.5\%), Chilectra of Chile (20\%), Endesa of Chile (10\%), Entergy of the U.S. (10\%), and PSI Energy of the U.S. (8\%). See David Pilling, "Argentina Comes Alive," Privatisation International, Number 88 (January 1, 1996).

${ }^{34}$ David Pilling, "Argentina Comes Alive," Privatisation International, Number 88 (January 1, 1996).

${ }^{35}$ The regulatory body is known as the National Entity of Electricity Regulation and often is referred to by its acronym, Enre. However, regular use of such acronyms may prove distracting to the reader and will be relegated to footnotes as often as practical.

${ }^{36}$ The market's Spanish name is El Mercado Electrico Mayorista (Mem).

${ }^{37}$ Peter R. Lalor and Hernan Garcia, "Reshaping power markets: Lessons from South America," Electricity Journal, Volume 9, Number 2 (March 1996), pp 63-71.

${ }^{38}$ The federal utility serving Buenos Aires was Servicios Electricos del Gran Buenos Aires (Segba). Segba was restructured into 6 power generation companies and 3 distribution companies in order to privatize it. Segba's transportation capabilities were transferred to create an electric transportation company during the restructuring.

${ }^{39}$ The distribution company serving northern Buenos Aires is Empresa Distribudora Electrica Norte (Edenor). Meanwhile, Empresa Distribudora Electrica Sur (Edesur) is the distribution company serving southern Buenos Aires.

40" Duke, Entergy in Winning Group Paying \$234 Million for Grid in Argentina," Electric Utility Week (July 5, 1993), p. 1

${ }^{41}$ The company was known as Compania de Agua y Energia Electrica (Ayee).

${ }^{42}$ The transmission company is Compañía de Transporte de Energía en Alta Tensión Red (Transener).

43،“Powerco Assumes Ownership of Guemes Power Station," PR Newswire (September 30, 1992).

${ }^{44}$ The company was known as Hidroelectrica Norpatagonica S.A.( Hidronor).

${ }^{45}$ The company was known as Empresa Social Electrica de Buenos Aires (Eseba) and was separated into 2 generation, 1 transmission company, and 3 distribution companies. See "Argentina Investment: Power Privatisations Run Into Opposition ," EIU ViewsWire (September 6, 1996).

46"CEA and AES Win Bids on Two Electric Distribution Systems in Argentina," PR Newswire (April 22, 1997).

${ }^{47}$ See "AES, Partner to Buy Argentine Power Firms," Reuters Financial Service (April 22, 1997) and "United Utilities Unit Consortium Wins 95-year Argentina Electricity Concession," AFX News (April 22, 1997).

48"Buenos Aires Kicks off Tender for Privatization of Eseba," Latin American Power Watch, Volume 3, Number 1 (February 1, 1997).

49، Argentina: Privatization of Eseba," International Market Insight Reports (April 1, 1997).

50،"United Utilities Unit Consortium Wins 95-year Argentina Electricity Concession," AFX News (April 22, 1997).

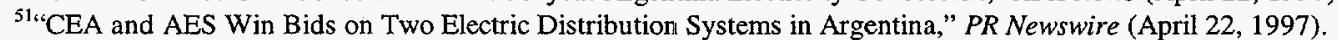

${ }^{52}$ Enre is formally known as Ente Nacional Regulador de la Electricidad. See Mariano F.Grondona, "Birth of a New Market," Infrastructure Finance (June/July 1994), p. 59.

${ }^{53}$ Claudio A. Onetto, "Competitive Restructuring," Independent Energy, Volume 26, Number 3 (April 1996), pp. 30-35.

${ }^{54}$ Peter R. Lallor and Hernan Garcia, "Reshaping Power Markets: Lessons from South America," Electricity Journal, Volume 9, Number 2 (March 1996), pp. 63-71.

55،"Houston Industries Group Buys Small Argentine Utilit,; Triples Rival Bids," Electric Utility Week (December 7, 1992 ), p. 1.

${ }^{56}$ Charles R. Moyer, "The Future of Electricity: Energy in the Twenty-First Century," Business Economics, Volume 31, Number 4 (October 1996 ), p. 13.

57، Staff Investigation on the Restructuring of the Electric Industry," Virginia State Corporation Commission, http://www.state.va.us/scc/restrct3.htm (May 12, 1997).

Market concentration may be a problem in Chile and the United Kingdom. For example, in Chile the electricity industry essentially is dominated by one company, Endesa (see Peter R. Lalor and Hernan Garcia, "Reshaping power markets: Lessons from South America," Electricity Journal, Vol. 9, No. 2 (March 1996), pp. 63-71.). It may be that Argentina is adopting a model designed to improve upon the Chilean and UK experiences.

${ }^{58}$ Guillermo Hiskel, "Interview: Argentine Utilities Form. Strategic Group," Reuters Financial Service (August 1, 1996).

${ }^{59} \mathrm{Cammesa}$, http://www.cammesa.com.ar/6de1.htm (June 3, 1997):

${ }^{61)}$ Cammesa, http://www.cammesa.com.ar/3de2.htm (June 3, 1997).

61"Advanced Technology for Argentina," European Power News (February 1997); and Jonathan Friedland and Benjamin A. Holden, "Utility Deregulation in Argentina Presages Possible U.S. Upheaval," The Wall Street Journal (June 19, 1996), p. A1.

${ }^{62}$ Other factors also enter into the determination of the price paid generators. These factors are discussed in the section below on electricity prices.

${ }^{63}$ Cammesa, http://www.cammesa.com.ar/8de2.html (June 11, 1997).

${ }^{64}$ Peter R. Lallor and Hernan Garcia, "Reshaping Power Markets: Lessons from South America," Electricity Journal, Volume 9, Number 2 (March 1996), pp. 63-71. 
${ }^{65}$ Transener is formally known as Compañía de Transporte de Energía en Alta Tensión Red.

${ }^{66}$ Personal conversation with Emilio Sawada of the Private Sector Department of the Inter-American Development Bank (Washington, DC, June 1997).

6\%“"Argentina to Accelerate Sale of Remaining Power Assets," Latin American Power Watch, Volume 2, Number 6 (July 1, 1996); and Ministry of Economy and Public Works and Services, http:/www.mecon.ar/invest/english/parti2h.htm (July 1, 1997).

${ }^{68}$ Bernardo E. Duggan and Victoria Zoldi, "A Guide to Energy, Natural Resources and Utilities Law: Argentina," International Financial Law Review (April 1996), Supplement pp. 3-7.

${ }^{69 ، " C h i l g e n e r ~ O p e n s ~ B i d d i n g ~ f o r ~ P o w e r ~ L i n e s, " ~ R e u t e r s ~ F i n a n c i a l ~ S e r v i c e ~(J a n u a r y ~ 16, ~ 1997) . ~}$

70،"Argentina Industry: Power Inflows To Spark Efficiency, Expansion," EIU ViewsWire (October 1, 1996).

${ }^{71}$ Argentina's Privatization Program: Experience, Issues, and Lessons (Washington, DC: The World Bank, 1993), p. 10.

${ }^{72}$ Facsimile provided by the Argentine embassy in Washington, DC (February 12, 1997), p. 2.

${ }^{73}$ Jonathan Friedland and Benjamin A. Holden, "Utility Deregulation in Argentina Presages Possible U.S. Upheaval," The Wall Street Journal (June 19, 1996), p. A1.

${ }^{74}$ Argentina's Privatization Program: Experience, Issues, and Lessons (Washington, DC: The World Bank, 1993 ), p. 10.

${ }^{75}$ Charles R. Moyeer, "The Future of Electricity: Energy in the Twenty-First Century," Business Economics, Volume 31, Number 4 (October 1996 ), p. 13.

${ }^{76}$ Cammesa, http://www.cammesa.com.ar/3de2.htm (June 3, 1997).

${ }^{77}$ Argentina Ministry of Economy and Public Works and Services, http://www.mecon.ar/invest/english/ (June 3, 1997).

78"'Energy. Argentina: the Silver Giant," Latin Finance, Number 75 (March 1996), p. 60A.

79،"Prices Have Plummeted in Argentine Spot Market, Where Ownership of Gas is Key," Power Markets Week (March 24, 1997 ), p. 12.

${ }^{80}$ Cammesa, http://www.cammesa.com.ar/sea.htm (June 11, 1997).

${ }^{81}$ Claudio A. Onetto, "Competitive Restructuring," Independent Energy, Volume 26, Number 3 (April 1996), pp. 30-35.

82"'Energy. Argentina: The Silver Giant," Latin Finance, Number 75 (March 1996), p. 60A.

83"'Prices Have Plummeted in Argentine Spot Market, Where Ownership of Gas is Key," Power Markets Week (March 24, 1997$)$, p. 12.

${ }^{84}$ Argentina Ministry of Economy and Public Works and Services, http://www.mecon.ar/invest/english/parti2h.htm (July 1, 1997).

85، Argentina; Ongoing Infrastructure Improvement," Infrastructure Finance (December, 1995/January, 1996), p. 2.

${ }^{86}$ Charles R. Moyer, "The Future of Electricity: Energy in the Twenty-First Century," Business Economics, Volume 31, Number 4 (October 1996), p. 13.

87،"Energy. Argentina: The Silver Giant," Latin Finance, Number 75 (March, 1996), p. 60A.

88"Advanced Technology for Argentina," European Power News (February 1997).

${ }^{89}$ David Pilling, "Argentina Comes Alive," Privatisation International, Number 88 (January 1, 1996).

90/، Argentina Industry: Power Inflows To Spark Efficiency, Expansion," EIU Views Wire (October 1, 1996).

${ }^{91}$ Companies having ownership in one or more of the companies comprising this consortium of electricity generators include: the U.S. companies CMS Energy Corp., Dominion Resources, Duke Power Co., and Southern Electric Co.; the Chilean companies Chilgener, Chilquinta SA, and Endesa; the Argentine companies Capsa and Cooperativa Provincial de Servicios Publicos y Comunitaries de Neuquen Limitada (electric cooperative); the Canadian company TransAlta Corp.; and the Japanese company OMRON Corp. See Guillermo Hiskel, "Interview: Argentine Utilities Form Strategic Group," Reuters Financial Service (August 1, 1996); and "Houston Industries Group Buys Small Argentine Utility, Triples Rival Bids," Electric Utility Week (December 7, 1992), p. 1 .

${ }^{92}$ Guillermo Hiskel, "Interview: Argentine Utilities Form Strategic Group," Reuters Financial Service (August 1, 1996).

${ }^{93}$ Leonard S. Hyman, The Privatization of Public Utilities (Vienna, Virginia: Public Utilities Reports, 1995), p. 71.

${ }^{94}$ Inter-American Development Bank, http://www.iadb.org/-http/argentina/argqfact.html (June 3, 1997).

95“"Energy. Argentina: The Silver Giant," Latin Finance, Number 75 (March, 1996), p. 60A.

96، Argentina: Ongoing Infrastructure Improvement," Infrastructure Finance (December 1995/January 1996), p. 2.

97، Argentina: Ongoing Infrastructure Improvement," Infrastructure Finance (December 1996/January 1997), p. 2.

${ }^{98}$ Argentina's Privatization Program: Experience, Issues, and Lessons (Washington, DC: The World Bank, 1993), pp. 13-14.

${ }^{99}$ Inter-America Development Bank, http://iadb6000.iadb.org/ http/argentina/arbsed.html (June 3, 1997).

${ }^{100}$ Two types of debt are discussed in this study. External debt is composed of Argentine private and public securities that are held by foreigners. Government debt is composed of future obligations owed by the federal government.

101، Argentina: Ongoing Infrastructure Improvement," Infrastructure Finance (December 1996/January 1997), p. 2.

${ }^{102}$ Stat-USA, http://www.stat-usa.gov/bems/bemsarg/argfact.html (May 20, 1997).

${ }^{103}$ Argentina's Privatization Program: Experience, Issues, and Lessons (Washington, DC: The World Bank, 1993), pp. 14-15.

${ }^{104}$ Stat-USA, http://www.stat-usa/bems//bemsarg/argfact.html (May 20, 1997).

${ }^{105}$ Michelle Wallin, "Argentina Politics Tense But Economy Remains Unfazed," The Wall Street Journal Interactive Edition, https://interactive.wsj.com/archive/retrieve@cgi (July 1, 1997),

${ }^{106}$ However, according to Argentina's statistics bureau (Indec), the increase in the unemployment rate from 17.1 percent in May 1996 to 16.3 percent in October 1996 was due to an increase in the labor force of 202,000, much of which was offset by a concurrent increase in jobs of 200,000. See Economic News Newsletter (Washington, DC: Argentine Embassy, January/February 1997), http://athea.ar/cwash/homepage/news197.htm (July1, 1997).

${ }^{107}$ Argentina's Privatization Program: Experience, Issues, and Lessons (Washington, DC: The World Bank, 1993 ), p. 14.

${ }^{108}$ The Brady Plan, so named for former U.S. Treasury Secretary Brady, was approved in 1989 and created a class of bonds called Brady bonds, or, more simply, Bradys. Commercial bank debt of a developing country is converted at a discount into Brady bonds. Brady bonds typically have a life of at least 10 years in length, and more than half those outstanding mature in 20 years or more after issuance. See Carol Palombo, "Brady Bonds: Past, Present and Future," Latin Finance, Number 79 (July 1996), p. 46. The plan allows countries to restore their credit status in the international community, giving them access to international capital markets. One of the preconditions of issuing Brady bonds is that the country implement strict fiscal monetary policies established by the International Monetary Fund that are expected to create both economic stability and sustainable growth.

${ }^{109}$ DRI/McGraw-Hill World Energy Service, Latin American Outlook, 1996 (1997), p. 25.

${ }^{110}$ DRI/McGraw-Hill World Energy Service, Latin American Outlook, 1996 (1997), p. 25.

${ }^{11}$ DRI/McGraw-Hill World Energy Service, Latin American Outlook, 1996 (1997), p. 25.

${ }^{112}$ Big Emerging Markets, U.S. International Trade Administration, U.S. Department of Commerce, http://www.stat-usa.gov/bem/bemsarg/argqfact.html (May 1997). 
${ }^{113}$ Michelle Wallin, "Argentina Politics Tense But Economy Remains Unfazed," The Wall Street Journal Interactive Edition https://interactive.wsj.com/archive/retrieve@cgi (July 1, 1997).

${ }^{114}$ Argentina's Privatization Program: Experience, Issues, and Lessons (Washington, DC: The World Bank, 1993), p. 15.

${ }^{115}$ Argentina's Privatization Program: Experience, Issues, and Lessons (Washington, DC: The World Bank, 1993 ), p. 14.

${ }^{116}$ Inter-American Development Bank, http://iadb6000.iadb.org/ http/argentina/arbsed.html (May 22, 1997).

${ }^{117}$ The Buenos Aires provincial electricity company billed $\$ 850$ million of electricity annually to 750,000 direct and 600,000 indirect clients (directly serviced by cooperatives purchasing power from Eseba) before its restructuring. The company was restructured into three distribution companies, two generation companies, and one transmission company. See "Argentina Investment: Power Privatisations Run Into Opposition," EIU ViewsWire (September 6, 1997).

${ }^{118}$ Energy Information Administration, AEO97 National Energy Modeling system, run AEO97B.D1002961C; and Latin America Report (Baldwyn, Pennsylvania: WEFA Energy, 1996), p. 2.15.

${ }^{119}$ Deepak Gopinath, "Power to the Customer," Infrastructure Finance (April 1997), p. 45.

${ }^{120}$ For example, acquiring distribution companies may ensure outlets for the generation that the companies are bringing on line in the same market. Distribution revenues also may balance cash flows from generation. Finally, distribution may pay a return on the investment more quickly than generation investment. See DeepakGopinath, "Power to the Customer," Infrastructure Finance (April 1997), p. 45.

${ }^{121}$ Leonard S. Hyman, The Privatization of Public Utilities (Vienna, Virginia: Public Utilities Reports, 1995), p. 63.

122“"HL\&P Parent in Group Vastly Outbidding Rivals for Small Utility in Argentina," Independent Power Report (December 4, 1992$)$, p. 1.

${ }^{123}$ Duke Power, http://www.dukepower.com/duke/faq.htm (June 10, 1997).

${ }^{124}$ Appendix C, Table Cl contains a listing of the companies with Argentine electricity investments, their primary line of business, their home country, and types of Argentine electricity investment.

125""The Race to Bridge Borders," The Economist (October 12, 1996), U.S. Edition, p. S18.

${ }^{126 ،}$ Transition Complete In Argentina's Entre Rios, CMS At Helm," The Energy Daily (May 21, 1996). 


\section{Appendix A}

U. S. Electric Utility Companies Not Investing in Argentina, Australia, and the United Kingdom 
Table A1. U.S. Electric Utility Companies Not Investing in Argentina, Australia, and the United Kingdom

\begin{tabular}{ll}
\hline Allegheny Power System & Florida Public Utilities \\
Atlantic Energy Inc. & FPL Group Inc. \\
Baltimore Gas \& Electric & Green Mountain Power Corp. \\
Bangor Hydro Electric & Hawaiian Electric Inds. \\
Black Hills Corp. & Idaho Power Co. \\
Boston Edison & IES Industries Inc. \\
Carolina Power \& Light & Illinova Corp. \\
Centerior Energy & Interstate Power Co. \\
Central Hudson Gas \& Elec. & IPALCO Enterprise Inc. \\
Central Louisiana Electric & Kansas City Power \& Light \\
Central Maine Power & KU Energy Corp. \\
Central Vermont Pub Serv. & LG\&E Energy Corp. \\
Cilcorp Inc. & Long Island Lighting \\
Cipsco Inc. & Madison Gas \& Electric Co. \\
Commonwealth Edison Co. & Main Public Services \\
Commonwealth Energy System & MDU Resources Group Inc. \\
Consolidated Edison of New York & Midamerica Energy HIdg. \\
Dayton Power \& Light Inc. & Montana Power Co. \\
Delmarva Power \& Light & Nevada Power Co. \\
DPL Inc. & New England Electric System \\
DQE Inc. & New York State Elec \& Gas \\
DTE Energy Co. & Niagara Mohawk Power \\
Eastern Utilities Assoc. & Nipsco Industries Inc. \\
EI Paso Electric Co. & Northwestern Public Serv Co. \\
Empire District Electric Co. & NRG Generating U.S. Inc. \\
Enova Corp. & OGE Energy Corp. \\
Environmental Power Corp & Ohio Edison Co. \\
Eselco Inc. & Orange \& Rockland Utilities \\
Florida Progress Corp & Otter Tail Power Co \\
\hline Source: Stand and Poors Compustat Jul 1997.
\end{tabular}

Peco Energy Co.

Pinnacle West Capital

Portland General Corp.

Potomac Electric Power

PP\&L Resources Inc.

Public Service of New Mexico

Public Service Enterprises

Puget Sound Energy Inc.

Rochester Gas \& Electric

Scana Corp.

Sierra Pacific Resources

Sigcorp Inc.

St Joseph Light \& Power

Teco Energy Inc.

TNP Enterprises Inc.

Tucson Electric Power Co.

UGI Corp.

Unicom Corp.

Union Electric Co.

United Illuminating Co.

Unitil Corp.

Upper Peninsula Energy Corp.

Washington Water Power

Western Resources

Wisconsin Energy Corp.

WPL Holdings Inc.

WPS Resources Corp.

York Research Corp.

Source: Standard and Poors Compustat, July 1997. 



\section{Appendix B}

Electricity Reform Milestones in Argentina, Australia, and the United Kingdom

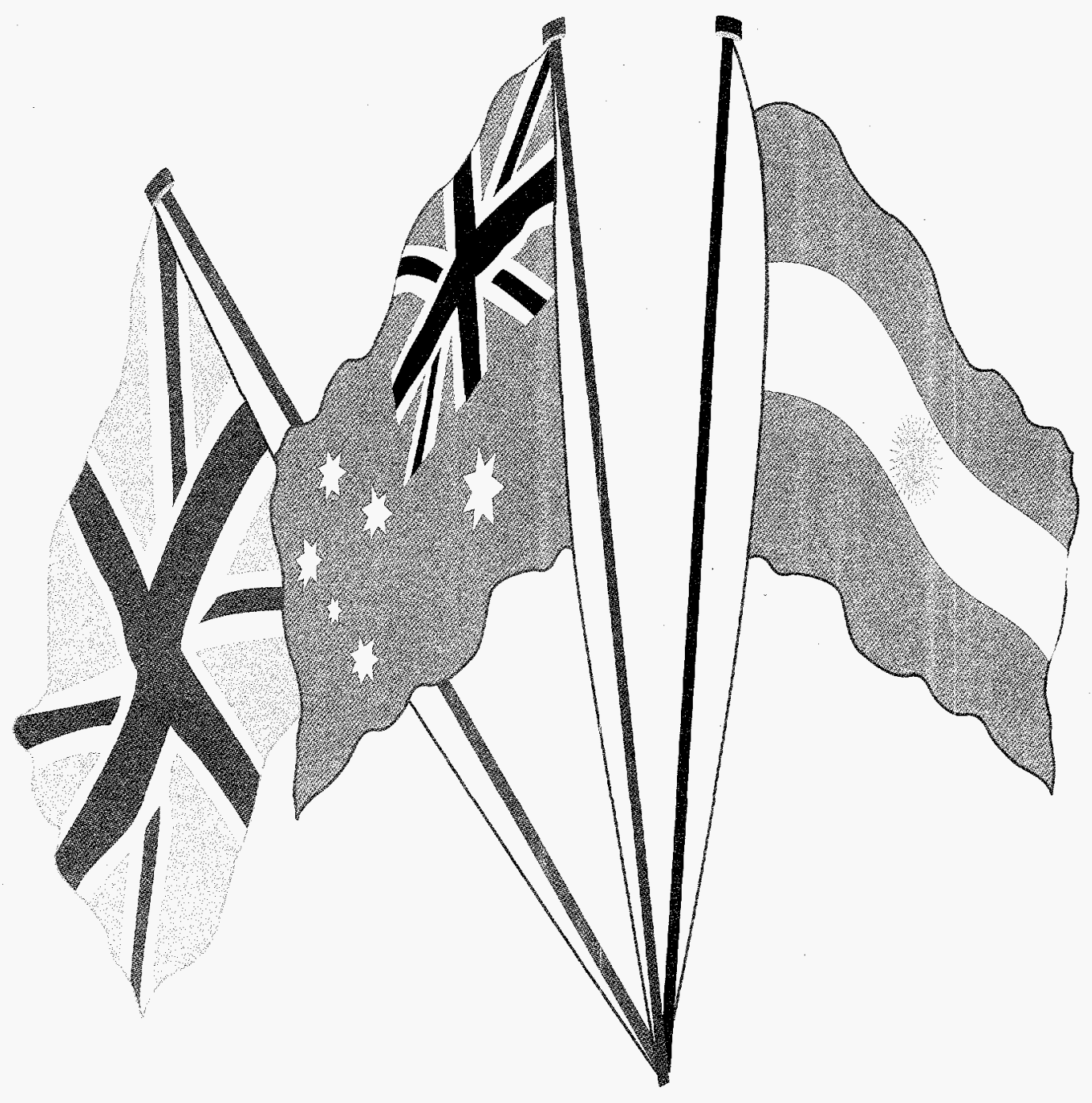




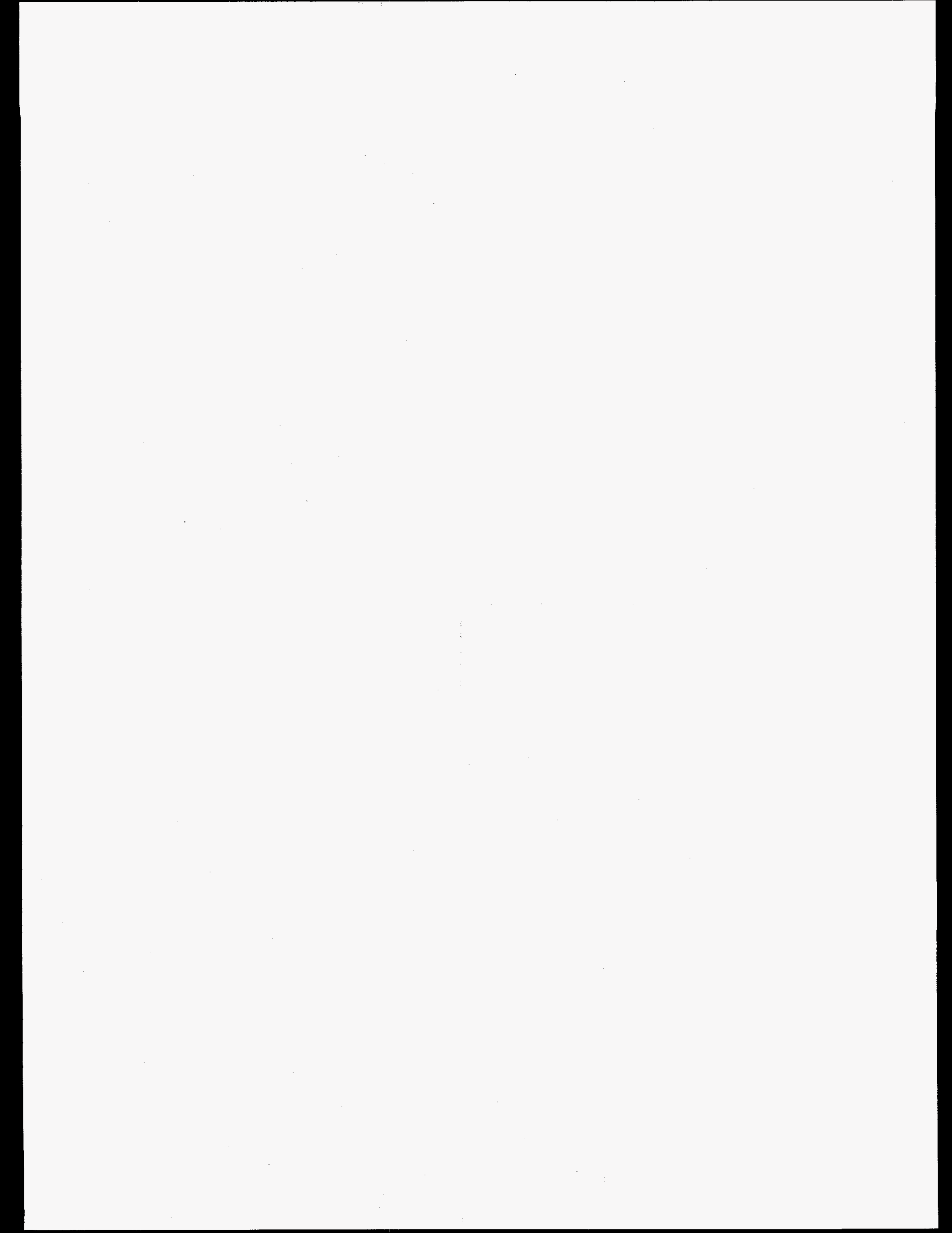




\section{Appendix B}

\section{Electricity Reform Milestones in Argentina, Australia, and the United Kingdom}

\section{Explanatory Notes}

This appendix is designed to aid the reader in following important electricity developments through time as they have occurred in Argentina, Australia, and the United Kingdom over the last century. These developments are discussed more fully (and in context) in Chapters 2, 3, and 4. Table B1 provides milestones for the United Kingdom. Tables B2 and B3 provide milestones for Australia and Argentina, respectively. 


\begin{tabular}{|c|c|}
\hline Date & Event \\
\hline $1947 \ldots$ & $\begin{array}{l}\text { First 100-percent federally-owned electric utility, Agua y Energia Electrica, Sociedad del Estado } \\
\text { (Ayee), was created. }\end{array}$ \\
\hline 1950 & $\begin{array}{l}\text { Argentina begins its nuclear research and development program, creating Comision Nacional de } \\
\text { Energia Atomica (Conea). }\end{array}$ \\
\hline $1957 \ldots$ & $\begin{array}{l}\text { Second 100-percent federally-owned electric utility, Servicos Electricos del Gran Buenos Aires } \\
\text { (Segba), was created to serve the Buenos Aires metropolitan area. }\end{array}$ \\
\hline 1977, March . . . . . . . & $\begin{array}{l}\text { The Foreign Investnnent Law is passed, allowing foreign investors for the first time to remit all their } \\
\text { profits from Argentine investments to their home country. }\end{array}$ \\
\hline 1982 & $\begin{array}{l}\text { Nationalization of electricity ends with the acquisition of the remaining investor-owned utility-Compania } \\
\text { Industrial de Argentina Electrica (Ciae). }\end{array}$ \\
\hline 1989 . & $\begin{array}{l}\text { The Economic Emergency Law passed, suspending all state subsidies and creating incentive } \\
\text { programs for mining and manufacturing companies. }\end{array}$ \\
\hline 1989, September . & $\begin{array}{l}\text { The Administrative Reform Law passed, defining the ground rules for investment in formerly } \\
\text { federally-owned companies. }\end{array}$ \\
\hline 1992, January & $\begin{array}{l}\text { The Electric Law passed, establishing a legal structure for the restructuring and privatization of the } \\
\text { electricity industry. }\end{array}$ \\
\hline 1992 & $\begin{array}{l}\text { The Bilateral Investment Treaty is signed, giving U.S. companies the right to invest in Argentina under } \\
\text { terms at least as favorable as those accorded Argentine firms. }\end{array}$ \\
\hline 1992, April & $\begin{array}{l}60 \text { percent of the thermal generator Central Puerto (formerly part of the federal electricity company } \\
\text { Segba) is sold to three Chilean electricity companies, marking the initial privatization of Argentina's } \\
\text { electricity industry. }\end{array}$ \\
\hline 1992, May & $\begin{array}{l}60 \text { percent of the thermal generator Central Costanera (formerly part of the federal electricity company } \\
\text { Segba) is sold to foreign companies, including the U.S. company Entergy. This was the first purchase } \\
\text { of an Argentine electricity company by a U.S. company. }\end{array}$ \\
\hline 1993 & $\begin{array}{l}\text { The Amendment to the Foreign Investment Law is passed, removing foreign investors' burdensome } \\
\text { requirement of receiving prior federal approval for all investment (a few investments still require the } \\
\text { prior approval step). }\end{array}$ \\
\hline 1993 & $\begin{array}{l}\text { The Decree } 1853 \text { is passed removing most remaining restrictions on foreign investment. The Decree } \\
\text { allows } 100 \text {-percent foreign ownership of Argentine firms and full repatriation of profits and capital to } \\
\text { the home country of foreign investors. }\end{array}$ \\
\hline
\end{tabular}


Table B2. Electricity Reform Milestones in Australia

\begin{tabular}{|c|c|}
\hline Date & Event \\
\hline 1990, November & $\begin{array}{l}\text { The Industry Commission recommended reforms that included the privatization and/or commerciali- } \\
\text { zation of all state-owned electricity industries. }\end{array}$ \\
\hline 1991, May & $\begin{array}{l}\text { The Commonwealth, state and territorial heads of government established the National Grid } \\
\text { Management Council, an intergovernmental advisory body, to develop the National Electricity } \\
\text { Code. }\end{array}$ \\
\hline $1993 \ldots$ & $\begin{array}{l}\text { The National Competition Policy Review, known as the Hilmer Commission Report, identified } \\
\text { industries (such as electric, gas, water, and road transport) where reform could yield substantial } \\
\text { benefits to Australia's economy. }\end{array}$ \\
\hline 1994, October & $\begin{array}{l}\text { The National Grid Management Council developed interim market arrangements and broad } \\
\text { objectives for the national electricity market, released in a report entitled "Restructuring of the } \\
\text { Electricity Supply Industry in Australia." }\end{array}$ \\
\hline 1995, April & $\begin{array}{l}\text { The Council of Australian Governments agreed to a national competition policy reform, the National } \\
\text { Competition Reform Act 1995, which provided, in part, for uniform protection of consumer and } \\
\text { business rights and increased competition in all jurisdictions. }\end{array}$ \\
\hline 1995, April - July & The first draft of the National Electricity Code was issued to the public for comment. \\
\hline 1995, September . . . . . . . . & $\begin{array}{l}\text { The National Grid Management Council prepared a second report detailing the market functions } \\
\text { proposed for the National Electricity Code. }\end{array}$ \\
\hline 1996, September & The National Electricity Code was finalized. \\
\hline 1996, November ......... & $\begin{array}{l}\text { The National Electricity Code was submitted to the Australian Competition and Consumer } \\
\text { Commission, with approval expected in late } 1997 .\end{array}$ \\
\hline 1997, May & $\begin{array}{l}\text { The first phase of the national electricity market began in New South Wales, Victoria, and the } \\
\text { Australian Capital Territory. }\end{array}$ \\
\hline 1997, October & $\begin{array}{l}\text { All the regulations of the National Electricity Code are to be imposed, except those for market rules } \\
\text { and system security, which will be governed by State Codes until the national market systems are } \\
\text { operational. }\end{array}$ \\
\hline 1997, October & Queensland is to participate in the national electricity market system. \\
\hline 1998 & $\begin{array}{l}\text { The national market systems are to be in operation and full implementation of market arrangements } \\
\text { will be applied according to the National Electricity Code. }\end{array}$ \\
\hline 1998 & South Australian generators will enter the market as full participants. \\
\hline \multirow[t]{2}{*}{ Date } & Electricity Reform Milestones in the Australian States \\
\hline & Victoria \\
\hline 1993, October & $\begin{array}{l}\text { Victoria's monopolistic electricity industry, the State Electricity Commission of Victoria, was } \\
\text { vertically separated into three segments: generation, distribution, and transmission. }\end{array}$ \\
\hline $1994 \ldots \ldots \ldots \ldots \ldots$ & $\begin{array}{l}\text { The government created state-owned entities. The generation sector was divided into } 5 \\
\text { competitive and independent companies. The former } 29 \text { electricity distribution companies were } \\
\text { merged into } 5 \text { companies and a transmission company, PowerNet Victoria, was created. }\end{array}$ \\
\hline $1994 \ldots \ldots \ldots$ & The state's wholesale market became operational. \\
\hline 1992, December ... & $\begin{array}{l}\text { Generation } \\
\text { In December 1992, Victoria began the privatization of its generation sector with the 51-percent sale } \\
\text { of its Loy Yang B power station to the U.S.-based Edison International's Mission Energy Company. } \\
\text { In May of 1997, Edison International purchased the remaining stake in the Loy Yang B power } \\
\text { station. }\end{array}$ \\
\hline
\end{tabular}




\begin{tabular}{|c|c|}
\hline Date & Event \\
\hline 1996, March & The generation plant, Yallourn-W, was sold to PowerGen PLC of the United Kingdom. \\
\hline 1996, August & $\begin{array}{l}\text { The Hazelwood coal-fired plant and a coal mine were sold to a group led by National Power PLC } \\
\text { of the United Kingdom. }\end{array}$ \\
\hline 1997, May & $\begin{array}{l}\text { The Loy Yang A coal-fired power station and a coal mine were sold to a consortium group led by } \\
\text { the U.S. company CMS Energy. This was the largest energy asset privatization in Australian } \\
\text { history. }\end{array}$ \\
\hline 1996 & $\begin{array}{l}\text { Customers with energy consumption of } 750 \text { megawatts per year became eligible to choose their } \\
\text { electricity marketer. }\end{array}$ \\
\hline 1995 & $\begin{array}{l}\text { Distribution } \\
\text { The state began the privatization of its electricity assets through the auction of all of its } 5 \text { electric } \\
\text { power distribution companies (United Energy, Solaris Power, Eastern Energy, Powercor, and } \\
\text { Citipower). }\end{array}$ \\
\hline \multirow[t]{2}{*}{1997} & $\begin{array}{l}\text { Transmission } \\
\text { PowerNet Victoria Transmission, the state-owned agency operating Victoria's high-voltage } \\
\text { electricity transmission grid, is expected to be privatized. }\end{array}$ \\
\hline & New South Wales \\
\hline 1991, August & $\begin{array}{l}\text { The states' monopolistic electricity industry, Electricity Commission of New South Wales, was } \\
\text { renamed Pacific Power and was restructured internally into six smaller business units. }\end{array}$ \\
\hline 1994 & $\begin{array}{l}\text { Pacific Power's electricity transmission network business unit was established as a separate legal } \\
\text { entity, the Electricity Transmission Authority, and was later separated from Pacific Power in } \\
\text { February } 1995 \text { to form a state-owned corporation (now called TransGrid). }\end{array}$ \\
\hline 1995 , October ... & $\begin{array}{l}\text { The state's previous } 25 \text { distribution boards were aggregated into six businesses and were later } \\
\text { corporatized }{ }^{1} \text { in March } 1996 \text {. }\end{array}$ \\
\hline 1996, May & The wholesale market became fully operational. \\
\hline 1997, July & $\begin{array}{l}\text { Customers with energy consumption of } 750 \text { megawatts per year became eligible to choose their } \\
\text { electricity marketer. }\end{array}$ \\
\hline 1997, May & $\begin{array}{l}\text { The New South Wales' treasurer, Michael Egan, announced his intentions to privatize all of the } \\
\text { state's electricity assets. }\end{array}$ \\
\hline 1995 & $\begin{array}{l}\text { Generation } \\
\text { A consortium consisting of Air Liquide Australia Ltd, Itochu Corporation (a Japanese company), } \\
\text { and Energy Australia (New South Wales' electricity distributor) was formed to develop a 350- } \\
\text { megawatt cogeneration plant in Sydney. }\end{array}$ \\
\hline 1995, December & $\begin{array}{l}\text { Energy Developments Limited (an Australian company) became involved in a 4-megawatt gas-fired } \\
\text { power plant, and a proposed } 90 \text {-megawatt coal steam methane power plant. }\end{array}$ \\
\hline 1995, December ... & $\begin{array}{l}\text { Sithe Energies (a U.S.-based independent power producer) and Broken Hill Proprietary (Australian- } \\
\text { owned) began the construction of a 175-megawatt cogeneration plant at Smithfield (near Sydney, } \\
\text { Australia), with commercial operations to begin in } 1997 \text {. }\end{array}$ \\
\hline 1997 . & Energy Australia withdrew from the cogeneration project in Sydney. \\
\hline & The Australian Capital Territory (ACT) \\
\hline 1995, July & The ACT's monopolistic electricity industry was corporatized. \\
\hline 1996, March . . . . . . . . . & The ACT began to participate in the New South Wales electricity market. \\
\hline
\end{tabular}




\begin{tabular}{|c|c|}
\hline Date & Event \\
\hline 1997, May & $\begin{array}{l}\text { The ACT began to operate in the national electricity market in conjunction with New South Wales } \\
\text { and Victoria. }\end{array}$ \\
\hline \multirow{2}{*}{$1997 \ldots \ldots \ldots \ldots \ldots \ldots$} & The ACT is to begin retail competition. \\
\hline & Queensland \\
\hline 1995, January ........... & $\begin{array}{l}\text { The state's monopolistic electricity company, the Queensland Electricity Commission, was } \\
\text { restructured and corporatized to form two new government corporations-- AUSTA Electric and the } \\
\text { Queensland Transmission and Supply Corporation (QTSC). }\end{array}$ \\
\hline Late $1997 \ldots \ldots \ldots \ldots \ldots$ & $\begin{array}{l}\text { AUSTA Electric is to be split into three generating companies that will compete amongst } \\
\text { themselves to supply the seven existing government electricity distributors. }\end{array}$ \\
\hline Late $1997 \ldots \ldots \ldots \ldots \ldots$ & Three new electricity marketing corporations are to be created. \\
\hline 1994, March . . . . . . . . . . & $\begin{array}{l}\text { Generation } \\
\text { The Queensland Electricity Commission sold the 1,650 megawatt coal base-load power station, } \\
\text { Gladstone, to Comalco (an Australian company) and Northern States Power (a U.S. company). }\end{array}$ \\
\hline $1994 \ldots \ldots \ldots \ldots \ldots$ & $\begin{array}{l}\text { The Broken Hill Proprietary Company (an Australian company) began construction of a 105- } \\
\text { megawatt gas-fired power station. }\end{array}$ \\
\hline 1996, August & $\begin{array}{l}\text { AUSTA Electric issued proposals to recommission generation plants (Collinsville and Callide-A) } \\
\text { and to have an interconnection transmission link with the state of New South Wales. Both projects } \\
\text { will be completed between } 1998 \text { to } 1999 \text {. }\end{array}$ \\
\hline 1997, April & $\begin{array}{l}\text { Australia Shell began a feasibility study for the construction of a power station in Callide, } \\
\text { Queensland. }\end{array}$ \\
\hline $2002 \ldots \ldots \ldots \ldots \ldots$ & The state plans to construct a 440-megawatt plant. \\
\hline 2003 to $2006 \ldots \ldots \ldots \ldots$ & $\begin{array}{l}\text { The state plans to build a power plant with generating capacity between } 600 \text { and } 1,400 \\
\text { megawatts. }\end{array}$ \\
\hline 1997, June . . . . . . . . & $\begin{array}{l}\text { Transmission } \\
\text { Queensland and New South Wales announced their intentions to built an interconnection grid link } \\
\text { between the two states, with operations to begin by } 2001 \text {. }\end{array}$ \\
\hline & South Australia \\
\hline $1995 \ldots$. & $\begin{array}{l}\text { The vertically-integrated state-owned utility, the Electricity Trust of South Australia, was } \\
\text { restructured and corporatized as ETSA Corporation. }\end{array}$ \\
\hline 1997, January & $\begin{array}{l}\text { ETSA Generation was separated from its parent company and became an independent } \\
\text { government business (ETSA Generation was formerly a subsidiary of ETSA Corporation). }\end{array}$ \\
\hline $1998 \ldots \ldots \ldots \ldots \ldots$ & The state is scheduled to participate in the national electricity market. \\
\hline Date & Western Australia \\
\hline 1995, January . . . . . . . . . & $\begin{array}{l}\text { The vertically integrated state-owned utility, the State Electricity Commission of Western Australia, } \\
\text { was divided into two independent electricity and gas corporations, trading as Western Power and } \\
\text { Alinta Gas. }\end{array}$ \\
\hline
\end{tabular}


Table B2. Electricity Reform Milestones in Australia (continued)

\begin{tabular}{|c|c|}
\hline Date & Event \\
\hline \multirow[t]{2}{*}{$1995 \ldots \ldots \ldots \ldots \ldots$} & $\begin{array}{l}\text { Edison International (a U.S. company), through its subsidiary Mission Energy, began a project to } \\
\text { build an \$111-million electric power plant. }\end{array}$ \\
\hline & Tasmania \\
\hline 1995, June . . . . . . . . . . & $\begin{array}{l}\text { The Hydro-electric Commission of Tasmania (HEC) passed legislation to allow the entry of new } \\
\text { participants and extended customer choice in the industry. (The HEC remains a vertically- } \\
\text { integrated, state-owned electricity business with separately organized generation, transmission, } \\
\text { and distribution segments.) }\end{array}$ \\
\hline $1996 \ldots$. & $\begin{array}{l}\text { A feasibility study that began in } 1993 \text { concluded that while it was technically possible to construct } \\
\text { a subsea-link between Tasmania and Victoria, the subsea-link would not be economic until the } \\
\text { year } 2000 \text {. }\end{array}$ \\
\hline \multirow[t]{3}{*}{ 1997, April } & $\begin{array}{l}\text { The state government announced intentions to introduce retail competition in its electricity industry } \\
\text { and to sell some of its equity interest in the electricity industry. }\end{array}$ \\
\hline & The Snowy Mountains Hydro-electric Scheme \\
\hline & $\begin{array}{l}\text { The Scheme will be corporatized under the national electricity market reforms and will sell } \\
\text { electricity on the national grid in competition with other states. }\end{array}$ \\
\hline
\end{tabular}

1 In Australia, in general a corporatized entity remains owned by the public sector, with a board nominated by the states. However, the company's operation and legal obligations are identical to those in the private sector. 
Table B3. Electricity Reform Milestones in the United Kingdom

\begin{tabular}{|c|c|}
\hline Date & Event \\
\hline 1926. & $\begin{array}{l}\text { The UK government passes Act establishing the central government's authority in electricity matters } \\
\text { through the Central Electricity Board. }\end{array}$ \\
\hline 1935 & The UK's central electricity grid goes into operation. \\
\hline 1947 & The electricity industries in England, Wales, and Southern Scotland are nationalized. \\
\hline 1947 & The British Electricity Authority assumes responsibility for generation and transmission. \\
\hline 1965 & $\begin{array}{l}\text { Natural gas is discovered in the North Sea, which (nearly } 2 \text { decades later) provides electric utilities with } \\
\text { an important alternative fuel. }\end{array}$ \\
\hline 1973-1974 & First oil price shock occurs: the UK moves towards greater reliance on nuclear power and domestic coal. \\
\hline $1978-1979 \ldots \ldots$ & Second oil price shock occurs further encouraging the UK toward greater reliance on domestic fuels. \\
\hline 1984-1985 & $\begin{array}{l}\text { Year-long miners strike ensues, calling into question reliance on domestic coal as the predominant } \\
\text { electricity fuel. }\end{array}$ \\
\hline 1986 & The Gas Act of 1986 is passed, deregulating the natural gas market and privatizing British Gas. \\
\hline 1988 & A Fossil Fuel Levy is introduced in order to subsidize nuclear power and nonrenewable fuel industries. \\
\hline 1989, July & $\begin{array}{l}\text { The Electricity Act of } 1989 \text { is passed, inaugurating a sweeping deregulation and privatization of UK } \\
\text { electricity. }\end{array}$ \\
\hline $1989 \ldots \ldots \ldots \ldots$ & $\begin{array}{l}\text { The UK government postpones nuclear power's privatization indefinitely due to concerns over potential } \\
\text { auction problems stemming from upward estimations of the financial costs associated with spent fuel } \\
\text { disposal and decommissioning. }\end{array}$ \\
\hline 1990, April ...... & $\begin{array}{l}\text { OFFER employs price caps to regulate distribution, transmission, and the still-regulated (tariff) marketing } \\
\text { services. }\end{array}$ \\
\hline 1990, April & $\begin{array}{l}\text { A new electricity industry comes into being. The new industry includes two thermal power producers } \\
\text { (National Power and PowerGen), a nation-wide transmission company (the National Grid Company), and } \\
\text { twelve regional electricity distribution companies (RECs). }\end{array}$ \\
\hline 1990, December .. & The RECs are auctioned off. \\
\hline 1991, March ..... & Sixty percent of the shares in the two newly-created power generation companies are auctioned off. \\
\hline 1991, July & OFFER introduces service standards for tariff customers. \\
\hline 1991, December & OFFER releases pool price inquiry report. \\
\hline 1992, October & Crisis ensues over coal contract negotiations. \\
\hline 1993, October & OFFER raises electricity service standards to tariff customers for the second time. \\
\hline 1993, March ...... & 3-year coal contracts officially expire. \\
\hline 1993, March . & $\begin{array}{l}\text { The UK government releases white paper presenting official government proposal on future 3-year coal } \\
\text { contract. }\end{array}$ \\
\hline 1993, April . . . . . . & OFFER places new price caps on National Grid Company. \\
\hline
\end{tabular}




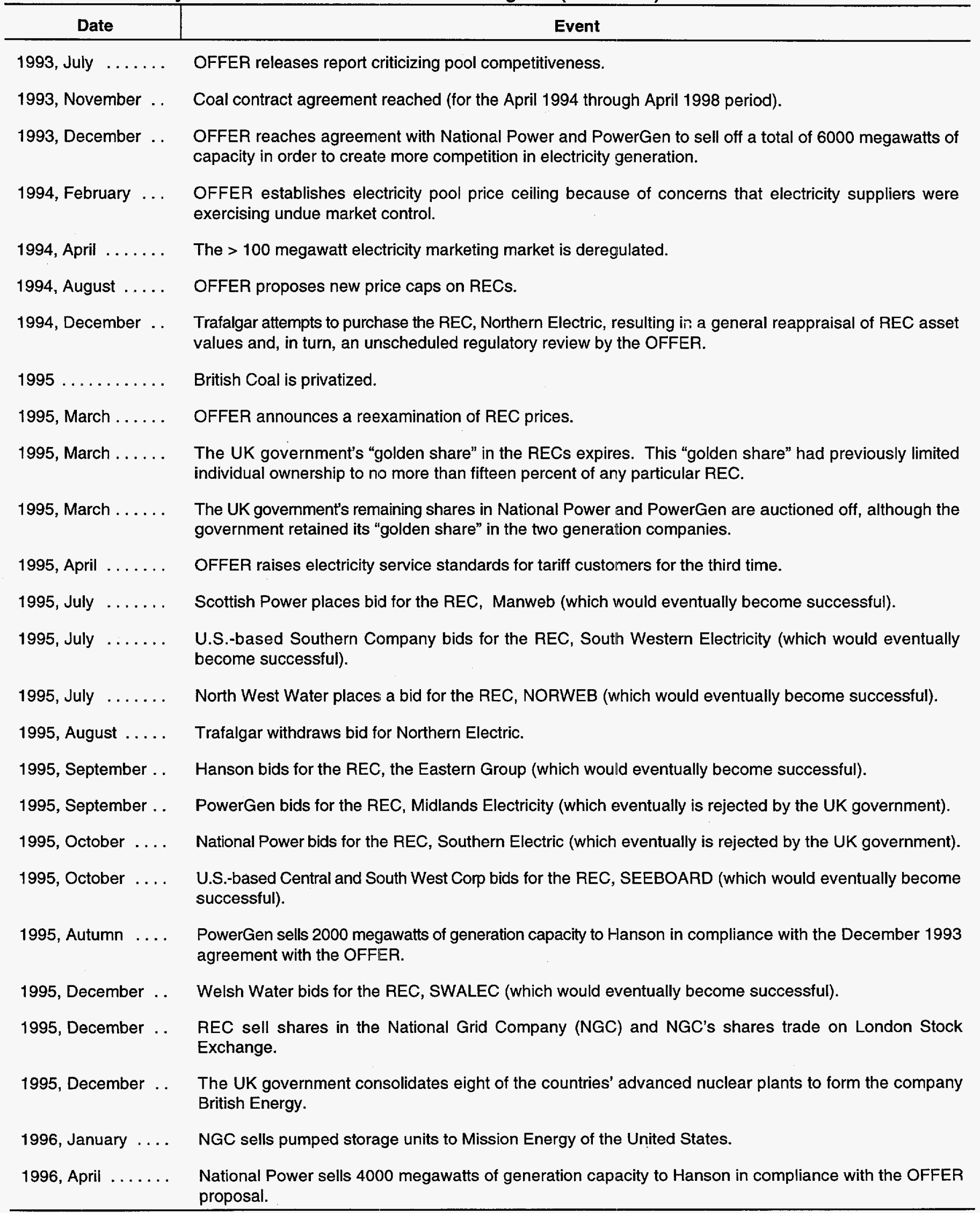


Table B3. Electricity Reform Milestones in the United Kingdom (continued)

\begin{tabular}{|c|c|}
\hline Date & Event \\
\hline 1996, April ...... & $\begin{array}{l}\text { U.S.-based Southern Company makes a bid for National Power (which is eventually rejected by the UK } \\
\text { government). }\end{array}$ \\
\hline 1996, April . . . . . . & $\begin{array}{l}\text { The UK Trade and Industry Secretary thwarts REC takeover attempts by National Power, PowerGen, } \\
\text { and the Southern Company. }\end{array}$ \\
\hline 1996, May ....... & $\begin{array}{l}\text { U.S.-based General Public Utilities and Cinergy bid for Midlands Electricity (which would eventually } \\
\text { become successful). }\end{array}$ \\
\hline 1996, July ...... & British Energy (which assumed ownership of the country's advanced nuclear reactors) is privatized. \\
\hline 1997, February & $\begin{array}{l}\text { U.S.-Based American Electric Power and Public Service of Colorado bid for the REC, Yorkshire } \\
\text { Electricity (which would eventually become successful). }\end{array}$ \\
\hline 1997, May ....... & Energy Group purchases the U.S. electric power marketing company, Citizens Power. \\
\hline 1997, June . . . . . . & $\begin{array}{l}\text { U.S.-based Pacificorp places a bid for the REC, Energy Group (the success of which had not been } \\
\text { determined by publication date of this report). }\end{array}$ \\
\hline 1998, March & Expiration date for the March 1994-March 1988 coal contract. \\
\hline 1998, April & $\begin{array}{l}\text { All of the electricity marketing segment is deregulated, implementing the final stage in the deregulation } \\
\text { of the UK electric marketing segment. }\end{array}$ \\
\hline
\end{tabular}





\section{Appendix C}

Review of Argentine

Electricity Privatization

Investment

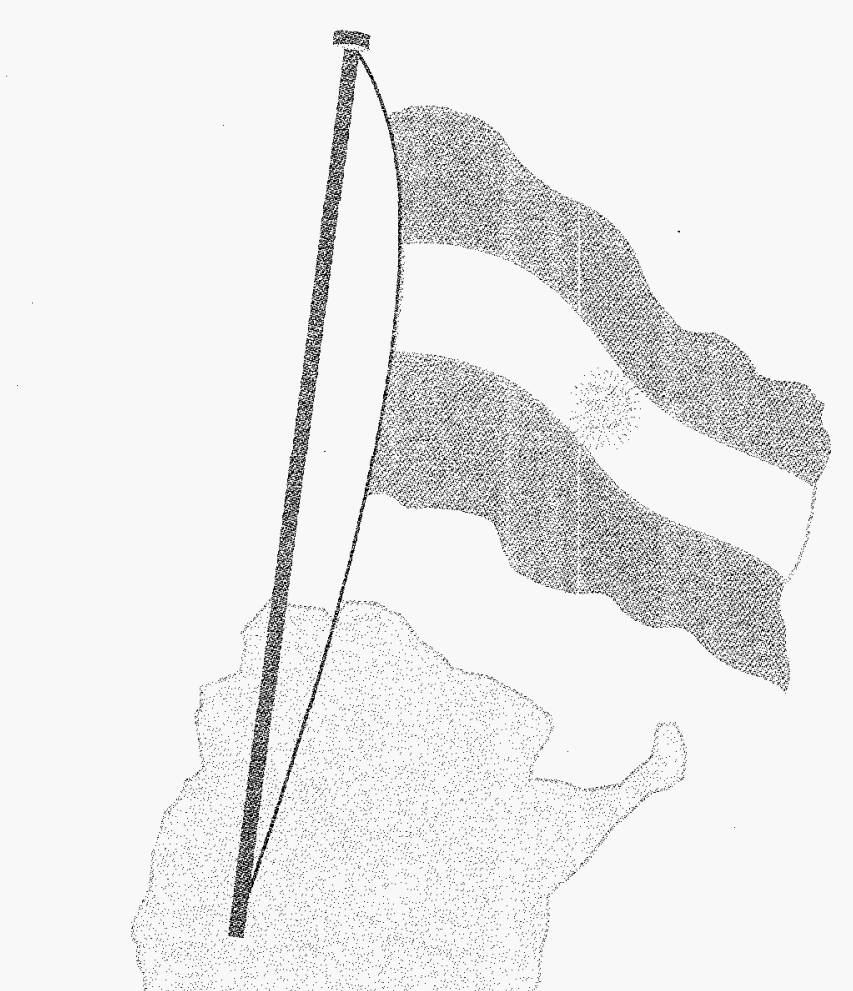

Argentina 



\section{Appendix C}

\section{Review of Argentine Electricity Privatization Investment}

\section{Explanatory Notes}

This appendix indicates the various companies that were created during Argentina's restructuring of its federal and provincial electricity companies. Table $\mathrm{C} 1$ contains investments made by foreign companies in Argentina's privatized electricity industry and is a more detailed version of Table 21 in the text. C2 provides details concerning the restructuring of federal electricity companies and Table C3 provides similar details for the rovincial electricity companies. The 1991 column refers to the pre-restructuring company and the 1997 column referrs to the post-restructuring company. Table C4 resents Argentine power generators built since restructuring began in 1991.

Similar reviews for the United Kingdom and Australia are contained within the text of the Chapters 2 and 3 , respectively. An appendix was used to present the Argentine review because of the many companies into which the federal and provincial electricity companies of Argentina were divided during the restructuring. 
Table C1. Foreign Companies' Investments in Argentina's Electricity Industry, as of 1997

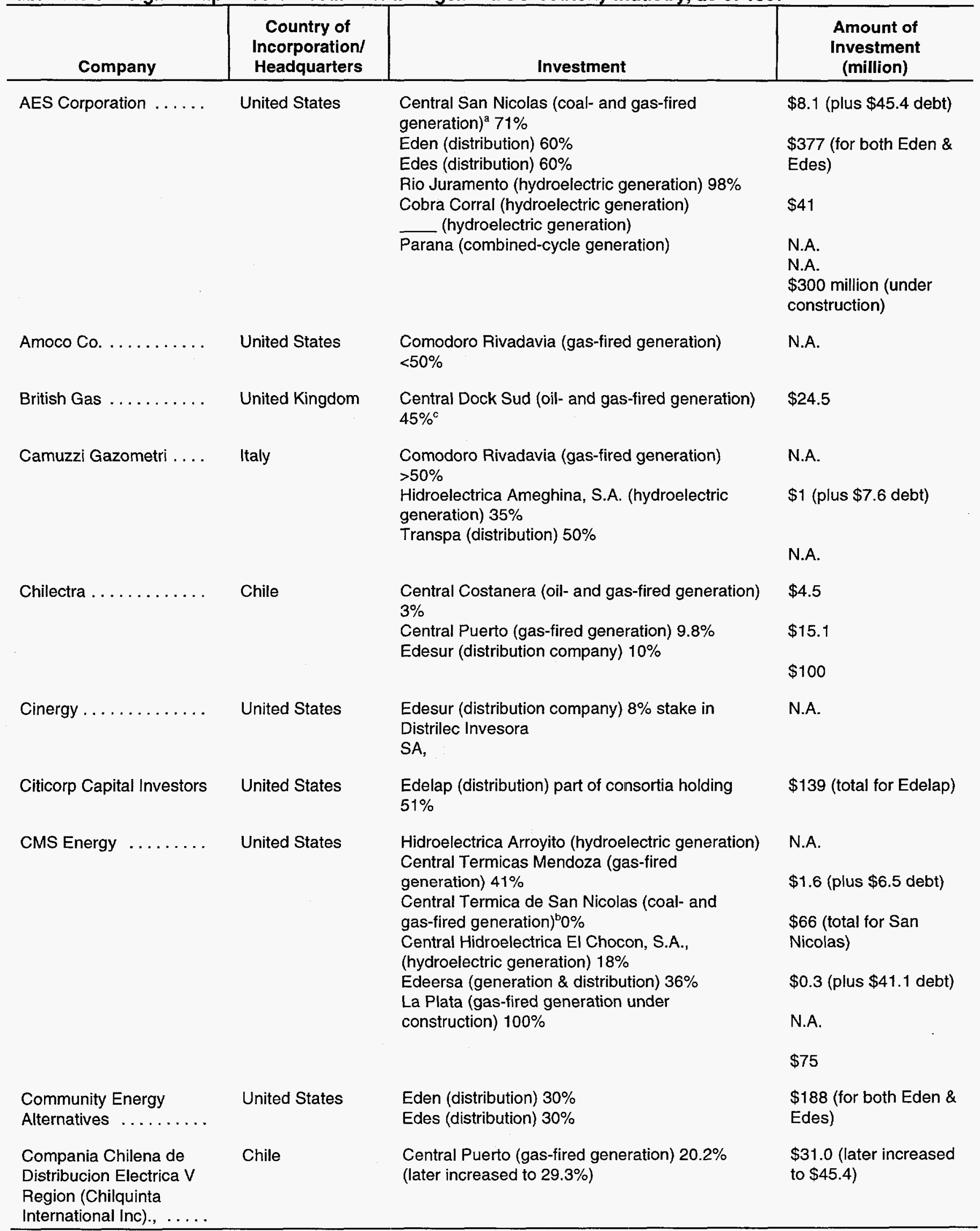


Table C1. Foreign Companies' Investments in Argentina's Electricity Industry, as of 1997 (continued)

\begin{tabular}{|c|c|c|c|}
\hline Company & $\begin{array}{l}\text { Country of } \\
\text { Incorporation/ } \\
\text { Headquarters }\end{array}$ & Investment & $\begin{array}{l}\text { Amount of } \\
\text { Investment } \\
\text { (million) }\end{array}$ \\
\hline $\begin{array}{l}\text { Compania Chilena de } \\
\text { Generacion Electrica } \\
\text { (Chilgener) } \ldots \ldots \ldots \ldots\end{array}$ & Chile & $\begin{array}{l}\text { Central Puerto (gas-fired generation) } 30.7 \% \\
\text { Edessa (distribution company) } 34 \% \\
\text { Piedra del Aguila (hydroelectric generation) } \\
15.8 \%\end{array}$ & $\begin{array}{l}\$ 47.6 \\
\$ 26.1 \\
\$ 89\end{array}$ \\
\hline Consumer's Energy Co. & United States & $\begin{array}{l}\text { Central Termica de San Nicolas (coal- and } \\
\text { gas-fired generation) }\end{array}$ & N.A. \\
\hline $\begin{array}{l}\text { Dominion Resources, } \\
\text { Inc., . . . . . . . . . }\end{array}$ & United States & $\begin{array}{l}\text { Central Alto Valle (gas-fired generation) } 60 \% \\
\text { Central Cerros Colorados (gas-fired generation) } \\
50.2 \%\end{array}$ & $\begin{array}{l}\$ 13.3 \\
\$ 23 \text { (plus } \$ 116.4 \text { debt) }\end{array}$ \\
\hline Duke Power ......... & United States & $\begin{array}{l}\text { Central Guemes (gas-fired generation) } 15 \% \\
\text { Hidroelectrica Piedra del Aguila, S.A. } \\
\text { (hydroelectric generation) } 19.7 \% \\
\text { Transener (transmission) } 9.8 \%\end{array}$ & $\begin{array}{l}\$ 2.5 \text { (plus } \$ 19.1 \text { debt) } \\
\$ 33 \text { (plus } \$ 57.4 \text { debt) } \\
\$ 4.5 \text { (plus } \$ 30.6 \text { debt) }\end{array}$ \\
\hline Electricite de France ... & France & $\begin{array}{l}\text { Distro Cuyo, S.A., (transmission) } 21 \% \\
\text { Edenor, S.A. (distribution) } \\
\text { Hidroelectrica Diamante, S.A. (hydroelectric } \\
\text { generation) } 29.5 \%\end{array}$ & $\begin{array}{l}\$ 8.3 \\
\$ 6 \text { (plus } \$ 79.6 \text { debt) } \\
\$ 2 \text { (plus } \$ 14.4 \text { debt) }\end{array}$ \\
\hline El Paso Energy ....... & United States & Agua del Cajon (gas-fired generation) $16 \%$ & $\$ 157$ \\
\hline Endesa de Chile ...... & Chile & $\begin{array}{l}\text { Buenos Aires S.A.(gas-fired generation) } \\
\text { Central Termoelectrica (_-fired generation) } \\
\text { Central Costanera (oil- and gas-fired generation) } \\
30 \% \\
\text { Central Dock Sud (oil- and gas-fired generation) } \\
90 \% \\
\text { Edesur (distribution) } 5 \%\end{array}$ & $\begin{array}{l}\text { N.A. } \\
\text { N.A. } \\
\$ 45 \\
\$ 350 \text {, including } \\
\text { planned expansion } \\
\text { through year } 2000 \\
\$ 3 \text { (plus } \$ 48.1 \text { debt) }\end{array}$ \\
\hline Endesa de España .... & Spain & $\begin{array}{l}\text { Edenor, S.A. (distribution) } 5.1 \% \\
\text { Yacylec (transmission) } 22.2 \%\end{array}$ & $\begin{array}{l}\$ 3 \text { (plus } \$ 39.8 \text { debt) } \\
\text { N.A. }\end{array}$ \\
\hline Enersis S.A. ........ & Chile & $\begin{array}{l}\text { Central Costanera (oil- and gas-fired generation) } \\
30 \% \\
\text { Edesur (distribution) } 10 \% \\
\text { Edesur (distribution) } 64 \% \text { (directly and through } \\
\text { Chilectra) } \\
\text { Edenor, S.A. (distribution) }\end{array}$ & $\begin{array}{l}\$ 13.5 \\
\$ 100 \\
\$ 390 \\
\$ 200 \text { (including new } \\
\text { distribution lines) }\end{array}$ \\
\hline Entergy Corp., ....... & United States & $\begin{array}{l}\text { Central Costanera (oil- and gas-fired generation) } \\
\text { part of consortium holding } 7.5 \% \\
\text { Transener (transmission) } 9.8 \% \\
\text { Edesur (distribution) } 5 \%\end{array}$ & $\begin{array}{l}\$ 4.5 \text { (plus } \$ 30.6 \text { debt) } \\
\$ 50\end{array}$ \\
\hline Houston Industries & United States & Edelap (distribution) $25 \%$ & $\$ 2.5$ (plus $\$ 65.7$ debt) \\
\hline $\begin{array}{l}\text { Hydroelectrica de } \\
\text { Ribagorzana, S.A. }\end{array}$ & Spain & Edenor, S.A., (distribution) $10.2 \%$ & $\$ 6$ (plus $\$ 79.6$ of debt) \\
\hline Iberdrola. & Spain & Central Guemes (gas-fired generation) & $\$ 2$ (plus $\$ 15.3$ debt) \\
\hline
\end{tabular}




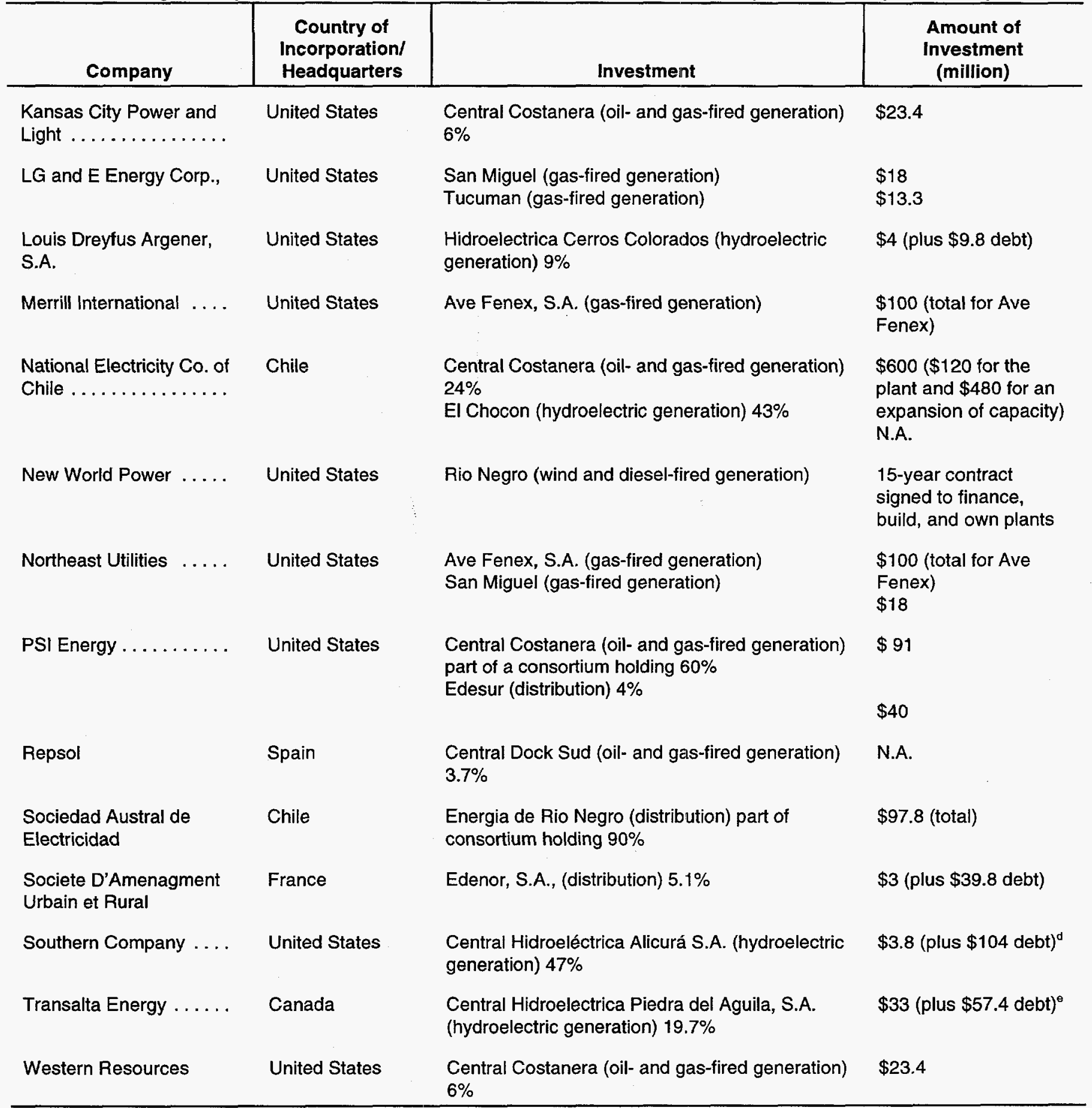

${ }^{a} A E S$ converted San Nicolas to a gas-fired generator. See Friedland, Jonathan and Benjamin Holden, "Utility Deregulation in Argentina Presages Possible U.S. Upheaval," The Wall Street Journal Interactive Edition (June 19, 1996).

${ }^{b} \mathrm{CMS}$ sold its share of San Nicolas to its partner AES. See Friedland, Jonathan and Benjamin Holden, "Utility Deregulation in Argentina Presages Possible U.S. Upheaval," The Wall Street Journal Interactive Edition (June 19, 1996).

${ }^{\circ}$ British Gas and its partners sold Central Dock Sud for a total of $\$ 1.3$ million less than 4 years after purchasing it. See Friedland, Jonathan and Benjamin Holden, "Utility Deregulation in Argentina Presages Possible U.S. Upheaval," The Wall Street Journal Interactive Edition (June 19, 1996).

${ }^{d}$ Southern has committed to spend $\$ 301.7$ over the initial 9 years of its 30 -year concession for Central Hidroelectrica Alicura.

${ }^{\circ}$ Transalta currently values its investment in Hidroelectrica Piedra del Aguila at $\$ 36.5$ million, which was written down at year end 1996 from $\$ 39.4$ million.

Sources: Annual reports to shareholders and various public news sources 


\begin{tabular}{c|c|c|c}
\hline \multicolumn{2}{c|}{1991} & \multicolumn{2}{c}{1997} \\
\hline Enterprise & Description & Enterprise & Description \\
\hline
\end{tabular}

Servicios Electricos del Gran Buenos Aires

(Segba) $\ldots \ldots \ldots \ldots \ldots$. generation and distribution company serving the Buenos Aires/La Plata area, which includes more than one-third of the country's population.
Agua del Cajon

Central Costanera

Central Dock Sud

Central Pedro de Mendoza

Central Puerto S.A.

Central Termoelectrica

Buenos Aires S.A.

Compañía de Transporte de Energía en Alta Tensión Red (Transenor)
Segba .............
non-Buenos Aires/La Plata generation and national transmission company, also oversaw Argentina's interests in the Yacyreta hydroelectric plant joint-venture with Paraguay
Empresa Distribudora
Electrica Norte (Edenor)

Empresa Distribudora
Electrica Sur (Edesur)

Empresa Distribudora

Electrica de la Plata (Edelap)

Agua del Toro

Cabra Corral

Central Alto Valle

Central Guemes

Central Sorrento
382 megawatt gas-fired power generation facility near Neuquen

1,260 megawatt oil-and gas-fired power generation facility

211 megawatt oil and gas-fired power generation facility

58 megawatt oil- and gas-fired power generation facility

1,009 megawatt gas-fired power generation facility

220 megawatt gas-fired power generation facility

created by combining the transmission assets of Segba, Ayee, and Hidronor; owns and operates the high voltage ( 500 kilovolts) segment of the transmission system serving 14 (of 24) Argentine provinces; and owns and operates a regional 220 kilovolt trunk transmission system

distribution company serving northern Buenos Aires

distribution company serving southern Buenos Aires

distribution company serving la Plata

150 megawatt thermal
generator

102 megawatt hydroelectric generator

165 megawatt gas-fired generator in the province of Neuguen $(700$ miles southwest of Buenos Aires)

245 megawatt gas-fired generator located in the Salta Province (northwest Argentina)

226 megawatt thermal generator (specific fuel not known) 
Table C2. Organization of Argentina's Federal Electricity Industry, 1991 and 1997 (continued)

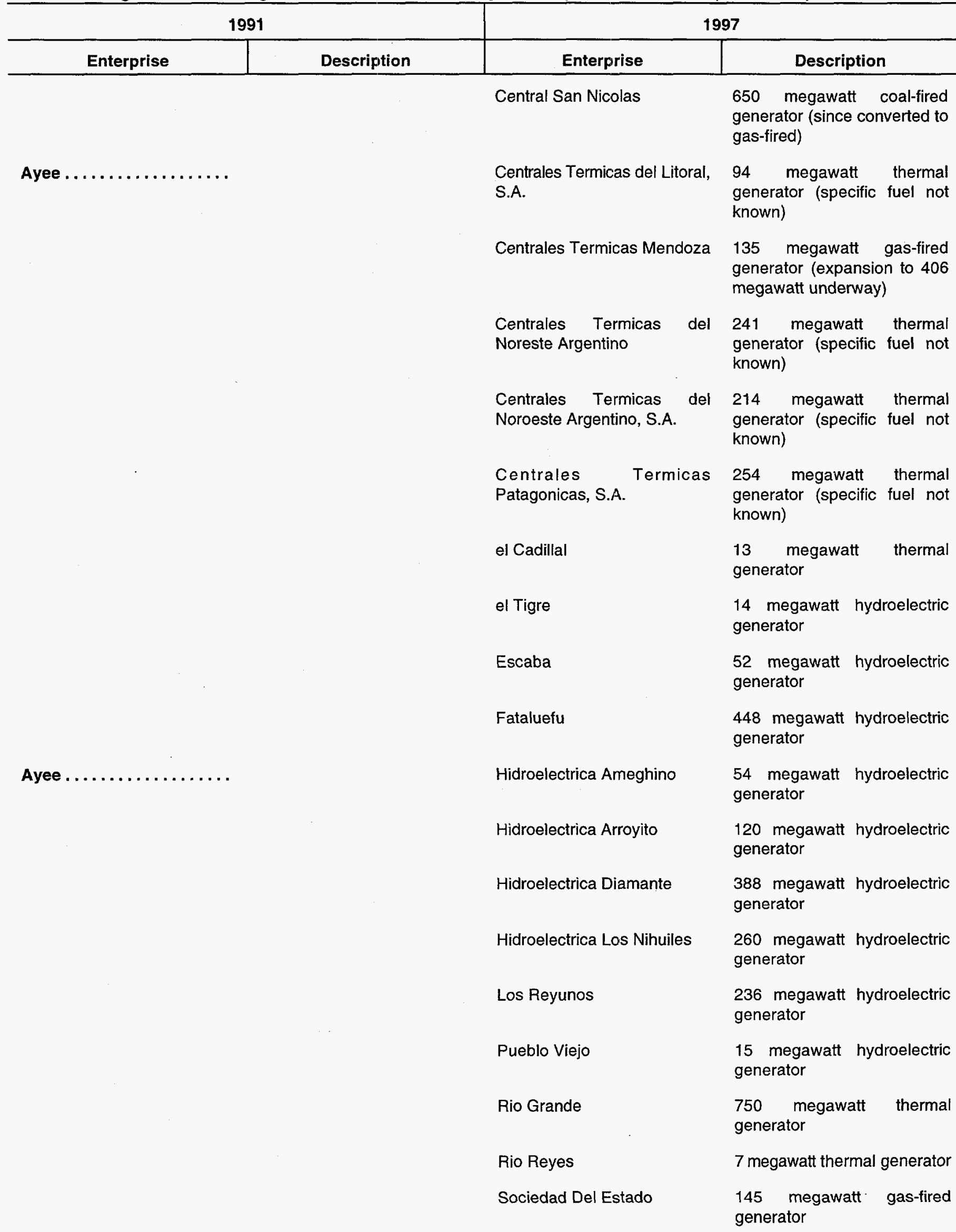


Table C2. Organization of Argentina's Federal Electricity Industry, 1991 and 1997 (continued)

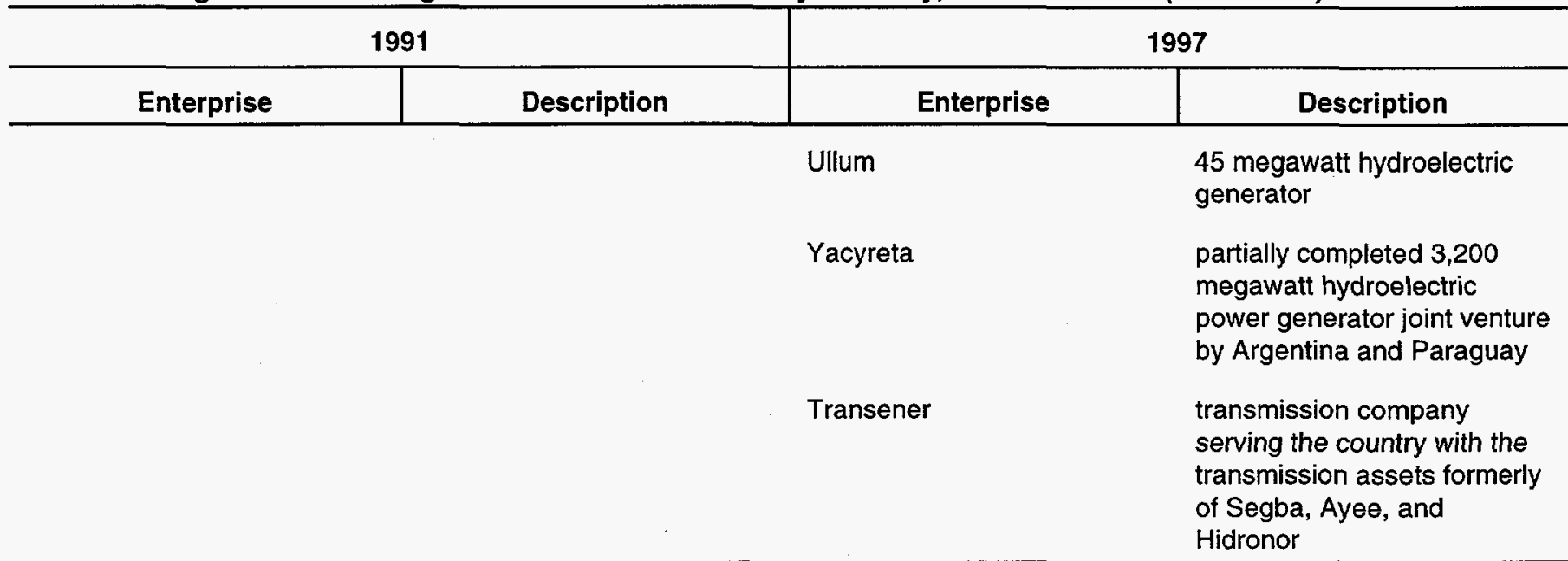

generation Central Hidroelectrica Alicura, S.A.

Central Hidroelectrica Cerros Colorados, S.A.

Central Hidroelectrica

Chocon

Hidroelectrica Piedra del

Aguila, S.A.

Pichi Picun Leufu

Transener

Nucleoelectrico Argentina S.A.

Nacional Nuclear Regulatory Authority (Enrn)
Hidroelectrica Norpatagonica S.A. (Hidronor) .......... hydroelectric company southern Argentina
1,000 megawatt hydroelectric generator

450 megawatt hydroelectric generator

EI 1,320-megawatt hydroelectric generator

1,440 megawatt hydroelectric generator

252 megawatt hydroelectric generator

transmission company serving the country with the transmission assets formerly of Hidronor, Segba, and Ayee

$\begin{array}{ll}\text { Comision Nacional de } & \text { national nuclear energy } \\ \text { Energia Atomica (Conea) } \cdots & \text { agency, created in } 1950 \text { to } \\ \text { conduct nuclear research, } & \text { oversees the operation of } \\ \text { nuclear power generation } \\ \text { units and regulates the } \\ \text { domestic nuclear industry }\end{array}$

oversees and operates Argentina's 2 completed (Atucha $I$ and Embalse) and 1 under-construction (Atucha II) nuclear plants

domestic nuclear regulatory agency. Will continue its role after privatization of the nuclear generation facilities

1,800 megawatt hydroelectric power generator joint venture by Argentina and Uruguay

Salto Grande (Ctmsg) . . . . .

Binational commission Salto Grande
overseeing the Salto Grande
hydroelectric plant
joint-venture with Uruguay

Sources: WEFA; Argentine Ministry of the Economy, http://www.mecon.ar/invest/energy/prim.htm (July 1, 1997); Electric Utility Week (various issues); Privatization (various issues); and Latin American Power Watch (various issues) 


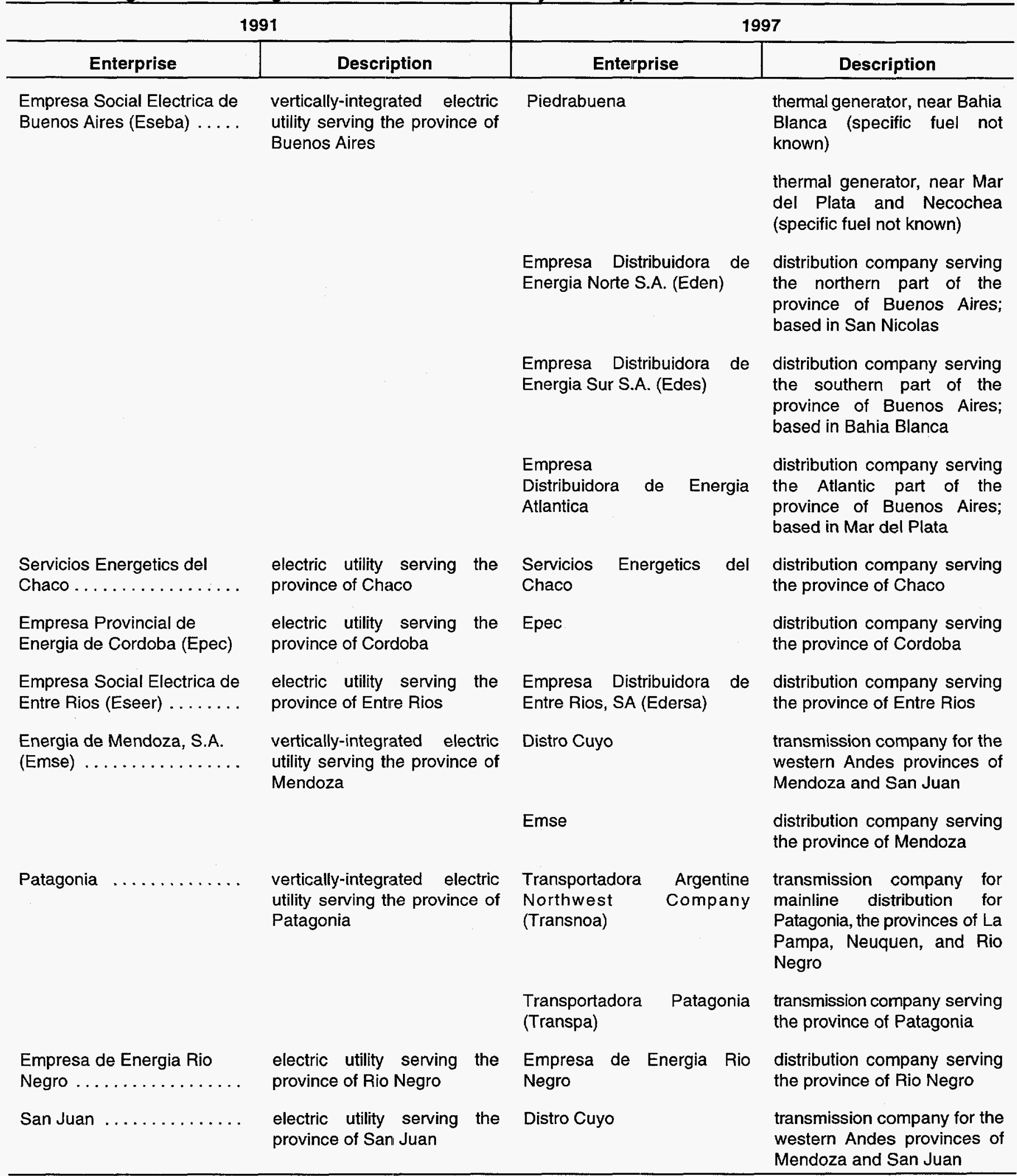


Table C3. Organization of Argentina's Provincial Electricity Industry, 1991 and 1997 (continued)

\begin{tabular}{|c|c|c|c|}
\hline \multicolumn{2}{|c|}{1991} & \multicolumn{2}{|c|}{1997} \\
\hline Enterprise & Description & Enterprise & Description \\
\hline $\begin{array}{l}\text { Empresa Provincial de } \\
\text { Energia de Santa Fe (Epe). }\end{array}$ & $\begin{array}{l}\text { electric utility serving the } \\
\text { province of Santa Fe }\end{array}$ & Epe & $\begin{array}{l}\text { distribution company serving } \\
\text { the province of Santa } \mathrm{Fe}\end{array}$ \\
\hline $\begin{array}{l}\text { Dirección Provincial de Tierra } \\
\text { del Fuego . . . . . . . . . }\end{array}$ & $\begin{array}{l}\text { electric utility serving the } \\
\text { province of Tierra del Fuego }\end{array}$ & $\begin{array}{l}\text { Dirección Provincial de Tierra } \\
\text { del Fuego }\end{array}$ & $\begin{array}{l}\text { distribution company serving } \\
\text { the province of Tierra del } \\
\text { Fuego }\end{array}$ \\
\hline \multirow{3}{*}{ Hidroelectrica Tucuman } & & Escaba & $\begin{array}{l}24 \text { megawatt hydroelectric } \\
\text { generator }\end{array}$ \\
\hline & & Pueblo Viejo & $\begin{array}{l}15 \text { megawatt hydroelectric } \\
\text { generator }\end{array}$ \\
\hline & & $\begin{array}{l}\text { Distribudora Electrica de la } \\
\text { Tucuman (Edet) }\end{array}$ & $\begin{array}{l}\text { Distribution company serving } \\
\text { the province of Tucuman }\end{array}$ \\
\hline
\end{tabular}

Sources: WEFA; Argentine Ministry of the Economy, http://www.mecon.ar/invest/energy/prim.htm (July 1, 1997); Electric Utility Week (various issues); Privatization (various issues); and Latin American Power Watch (various issues).

Table C4. Argentine Power Generators Built Since 1991

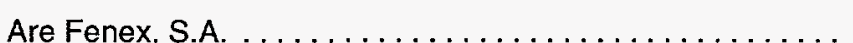

Comodoro Rivadavia

La Plata

San Miguel
168 megawatt gas-fired power generator near the city of Tucuman

Gas-fired power generator in the area of Patagonia

120 megawatt gas-fired power generator in the province of Buenos Aires

114 megawatt gas-fired power generator in San Miguel (north central Argentina)

Sources: WEFA; Argentine Ministry of the Economy, http://www.mecon.ar/invest/energy/prim.htm (July 1, 1997); Electric Utility Week (various issues); Privatization (various issues); and Latin American Power Watch (various issues) 
The Energy Information Administration's latest Energy InfoDisc $C D-R O M$ now has Internet connectivity, the exciting feature that links you to EIA's World Wide Web Site.

The most comprehensive collection of energy information and analysis tools available today

Featuring special topics like the changing structure of the electric power industry

Information from more than 200 of EIA's current periodicals, analytical publications, and articles

Speed and portability of CD-ROM, plus access to frequent updates and new products on EIA's Web Site

Advanced search capability

Instant access to EIA's wide range of national energy database applications

A must for anyone needing current or historical energy information.

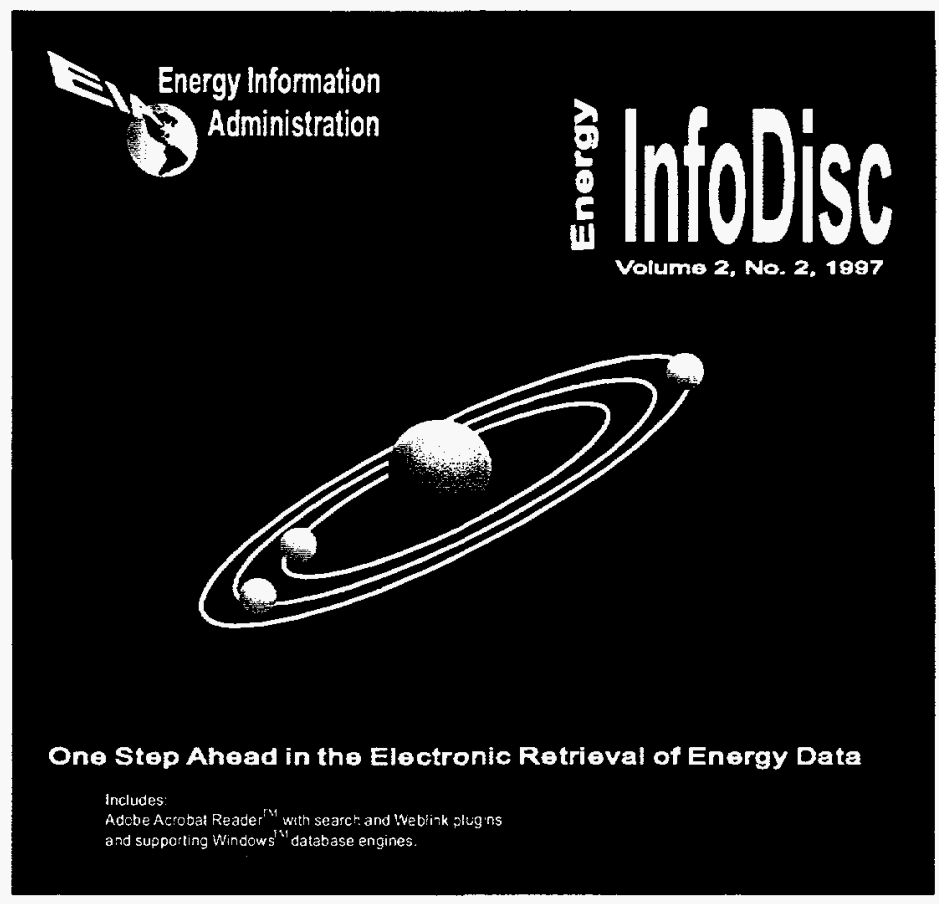

NOTE: Documents can be accessed using either Microsoft Windows or Macintosh System 7 operating systems.

Databases and applications can only be accessed using Microsoft Windows.

\section{Don't be without this important resource. SubscribeToday!}

EIA is the independent statistical and analytical agency within the U.S. Department of Energy. Energy InfoDisc is brought to you through a cooperative agreement with STAT-USA, the business information service of the U.S. Department of Commerce.

\section{STAT-USA Order Form}

Yes, enter my order for the Energy InfoDisc CD-ROM:

Number of copies:

$\square$ Single issue (U.S., Canada, \& Mexico): \$45

$\square$ Single issue outside the U.S., Canada, \& Mexico: $\$ 60$

$\square$ Quarterly subscription in the U.S., Canada, \& Mexico: $\$ 100$

$\square$ Quarterly subscription outside the U.S., Canada, \& Mexico: $\$ 160$

Contact or personal name $\quad$ (please type or print)
Company

Street address

Additional address

City, State, ZIP Code

Daytime phone

\section{Charge your order \\ It's easy!

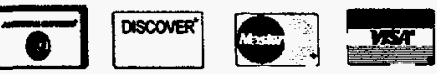 \\ To fax your orders (202) 482-2164 \\ To phone your orders (202) 482-1986 \\ Toll Free: 1- (800) STAT-USA}

For privacy protection, check the box below:

$\square$ Do not make my name available to requesters.

Check method of payment:

$\square$ AMEX $\square$ Discover $\square$ MasterCard $\square$ VISA

(expiration date)

Authorizing signature

$\square$ Check payable to STAT-USA

Mail to: U. S. Department of Commerce

STAT-USA, Room H-4885

Washington, DC 20230

Publication Ad 